\title{
Innovations and firm performance in sub-Saharan Africa
}

Citation for published version (APA):

Avenyo, E. K. (2018). Innovations and firm performance in sub-Saharan Africa: Empirical analyses.

[Doctoral Thesis, Maastricht University]. https://doi.org/10.26481/dis.20180524ea

Document status and date:

Published: 01/01/2018

DOI:

10.26481/dis.20180524ea

Document Version:

Publisher's PDF, also known as Version of record

\section{Please check the document version of this publication:}

- A submitted manuscript is the version of the article upon submission and before peer-review. There can be important differences between the submitted version and the official published version of record.

People interested in the research are advised to contact the author for the final version of the publication, or visit the DOI to the publisher's website.

- The final author version and the galley proof are versions of the publication after peer review.

- The final published version features the final layout of the paper including the volume, issue and page numbers.

Link to publication

\footnotetext{
General rights rights.

- You may freely distribute the URL identifying the publication in the public portal. please follow below link for the End User Agreement:

www.umlib.nl/taverne-license

Take down policy

If you believe that this document breaches copyright please contact us at:

repository@maastrichtuniversity.nl

providing details and we will investigate your claim.
}

Copyright and moral rights for the publications made accessible in the public portal are retained by the authors and/or other copyright owners and it is a condition of accessing publications that users recognise and abide by the legal requirements associated with these

- Users may download and print one copy of any publication from the public portal for the purpose of private study or research.

- You may not further distribute the material or use it for any profit-making activity or commercial gain

If the publication is distributed under the terms of Article $25 \mathrm{fa}$ of the Dutch Copyright Act, indicated by the "Taverne" license above, 
Innovations and firm performance in sub-Saharan Africa:

\section{Empirical analyses}

\section{DISSERTATION}

to obtain the degree of Doctor at Maastricht University, on the authority of the Rector Magnificus Prof. Dr. Rianne M. Letschert, in accordance with the decision of the Board of Deans, to be defended in public on Thursday, 24 May 2018, at 16:0o hours 
PROMOTER AND SUPERVISOR:

Prof. Dr. Pierre Mohnen

CO-SUPERVISOR:

Dr. Maty Konte

ASSESSMENT COMMITTEE:

Prof. Dr. Martin Carree (Chair)

Prof. Dr. Xiaolan Fu (University of Oxford, United Kingdom)

Prof. Dr. Fred Gault (Professor Extraordinaire, Tshwane University of Technology, South Africa)

Dr. Micheline Goedhuys 
This thesis starts from the premise that innovations offer good prospects for sustainable economic progress and economic transformation. The thesis provides empirical evidence on the innovation activities of firms in sub-Saharan Africa, with specific emphasis on the innovative process, the market performance of new products and the labour market impacts of new products.

Chapter 1 provides a general introduction to the thesis.

Chapter 2 investigates and presents new evidence on the impact of product innovations on employment. The chapter extends and applies a novel dose response model under different intensities of innovation using the World Bank's Enterprise Survey (ES) merged with the newly available Innovation Follow-Up Survey data, covering the period 2010-2012, for 5 sub-Saharan African countries. The main finding is consistent with the stylised fact in the empirical literature, with product innovations having compensation impact on total employment. We, however, found this conclusion to be invalid beyond sub-interval of firms' product innovation intensities. In extension, we found that product innovation is biased towards temporary employment, though it creates both permanent and temporary jobs.

Chapter 3 examines the relationship between informal product market competition and sales from innovative products introduced by formal firms, using pooled data from the World Bank's Enterprise Survey and the Innovation Follow-up Survey for 5 sub-Saharan African countries. The results reveal a robust 'Schumpeterian effect' (monotonically negative effect) of informal competition on the market performance of product innovations. Results from sectoral, ownership type and size of firm analyses also show similar 'Schumpeterian effects'. However, extension to industry-level informal competition indicates an 'escape-competition effect' of informal competitive activities on the performance of product innovations. We also found through indirect mechanisms that firms with larger market share tend to have 'escape-competition effects'. We argue that informal competition matters for the performance of product innovations but only for formal firms that lack strategic collaborative 'footholds' in the informal economy.

Chapter 4 focuses on understanding and providing insights into the types of innovations informal enterprises use, and adapt to meet the needs of customers. The chapter describes the data collection procedure, followed by descriptive statistics of enterpriselevel data collected in urban Ghana (Accra and Tema). The descriptive statistics indi- 
cate that innovations are pervasive in the informal economy of Ghana, with informal enterprises generating innovative ideas internally.

Chapter 5 investigates the effect of apprenticeship and formal interactions as learning processes on the innovation activities of informal enterprises in Ghana. Based on modern econometric methodologies and a unique data set on 513 enterprises, the findings suggest that both apprenticeship and competitive formal interactions enhance product innovativeness. Innovation policy in Ghana, therefore, needs to promote learning processes in informal enterprises.

Chapter 6 concludes the thesis with some policy recommendations and suggested areas for future research. 
Wow! What an incredible journey these 4 years have been. The journey began as a solemn, intellectual dream filled with high optimism. Like every journey, I have experienced lows and highs, and I could not have reached this destination without the relentless support of numerous people.

My foremost gratitude goes to my warm and always welcoming supervisory team, Prof. Dr. Pierre Mohnen and Dr. Maty Konte. I am deeply grateful for agreeing to embark on this journey with me and opening your doors anytime I needed your assistance and direction. You profoundly motivated and shaped me on this path.

I am thankful to my thesis assessment committee - Prof. Dr. Martin Carree, Prof. Dr. Xiaolan Fu, Prof. Dr. Fred Gault and Dr. Micheline Goedhuys - for their constructive, thought-provoking and timely comments. Your comments have greatly improved the quality of my thesis.

I wish to say a sincere thank you to Prof. Dr. Adam Szirmai, Prof. Dr. Theophile Azomahou, Prof. Dr. Shyama Ramani and Dr. Dorcas Mbuvi for their immense support. Thank you to Prof. Dr. Bart Verspagen and Dr. Hugo Hollanders for the opportunity to work as a research assistant on the UNESCO Science Report: Towards 2030. It was a great learning experience. Special thank you to Prof. Dr. Robin Cowan, Dr. Tatiana Skripka and Dr. Mindel van de Laar for their commitment to my PhD progress over the years.

My time at UNU-MERIT would not have been fulfilling without Eveline in de Braek. Thank you Eveline for never been too busy to listen and provide a supportive 'hug'. You are the best! Thanks to Marc, Ad and Herman for their desire to always lend a helping hand. I would also like to say a big thanks to Sueli, Wilma, Mieke, Ingeborg, Monique and Ingrid for warm smiles even on cold winter days. Your smiles brightened my days at MERIT.

My PhD journey has been filled with joy, challenges, celebrations, lessons and special moments that will stay with me forever. I feel blessed to have had the most amazing cohort to share these special moments with. We had some difficult moments, but we cycled through it all together and the strong esprit de corps we have developed over the years has been a great fortitude. I believe we will remain binded wherever we find ourselves in our various onward journeys. Thank you Elise (Mama Africa), Elisa, Mary, Iulia, Ibrahima (Koulibaly), Hassen (Boss), Mueid, Nana, Tamer, Youssef, Mira, Alison, Charlotte, Ayla, Rashmi and Jennifer. 
During this journey, I had the opportunity to also conduct my own survey in Ghana, where I worked with Awal, Seth, Tracy and Evelyn. Thanks 'team' for the hard work and sacrifice in the most difficult circumstances. I would also like to say a big thank you to all my respondents for their time and honest responses.

The journey was as well a social, religious and physical trip. I am indebted to Davina Osei for all the inspiration and support. Thank you, Serwaa. I would also like to extend my appreciation to Victor, Emma, Solomon, Martin Ayanore, Isaac, Benjamin Junior, Halleluyah, Testimony, Gideon, Cho, Themba, Martin, Edith, Happiness, Godsway, Ebenezer, Violet, Salomey, Onallia, Takuma, Racky and Chuks. Thank you guys for been a 'clan', and making Friday nights memorable. My heartfelt appreciation to the Bethel family who provided prayers and a home away from home. I owe thanks to Pastor Benjamin Odetola Benjamin, Mrs. Janet Odetola Benjamin, Paa Cole, Oke, Skutta and Dada families.

I have been lucky to also meet and interact with several other colleagues and special friends along this journey: Erika, Francesca, Sachin, Hibret, Diego, Hugo, Jeremy, Fernando, Clotilde, Janyl, Gintare, Mario, Iman (The Institute), Shuan, Wondimagegn, Tobias, Jamel, Andrea, Tigist, Paula, Louise, Elsa, Silas, Irmgard, Eleni, Adam, Melissa, Rosa, Gabriel, Stefania, Danilo, Rose, Patima, Tatenda, Lika, Beatriz, Norman and Ivy. Thanks also to my awesome office mates: Florian, Richard, Thuy, Ayo, Yesuf, Juan Carlos, Michelle and Kaleab.

The people I have met and the experiences I have had along 'journey Maastricht' have made lasting impressions not only on me, but also in my heart. I am grateful to have had the opportunity to meet each one of you. I will, forever, cherish the memories and wonderful moments we shared. Lastly, I thank God for his unwavering faithfulness. Onto the next journey! 
To family - blood and water. 



\section{CONTENTS}

I INTRODUCTION AND MOTIVATION

$\begin{array}{ll}\text { References } & 6\end{array}$

2 EMPLOYMENT IMPACT OF PRODUCT INNOVATIONS IN SUB-SAHARAN AFRICA: FIRM-LEVEL EVIDENCE 9

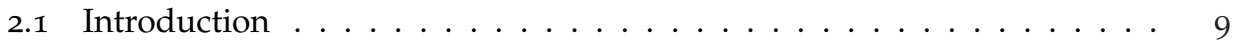

2.2 Related literature . . . . . . . . . . . . . . . . I1

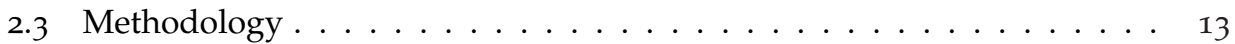

2.3.1 Theoretical and empirical models ............. 13

2.3.2 Data and measurement . . . . . . . . . . . . . . 19

2.4 Empirical results and discussion . . . . . . . . . . . . . . 23

2.4.1 Estimation results . . . . . . . . . . . . . . . . 23

2.4.2 Extension to decent employment . . . . . . . . . . . . 26

2.4 .3 Additional Robustness . . . . . . . . . . . . . . . . . . . . 27

2.5 Conclusion . . . . . . . . . . . . . . . . . . . . . 29

References $\quad 29$

A APPENDIX 34

3 PRODUCT INNOVATIONS AND INFORMAL MARKET COMPETITION IN SUBSAHARAN AFRICA: FIRM-LEVEL EVIDENCE 41

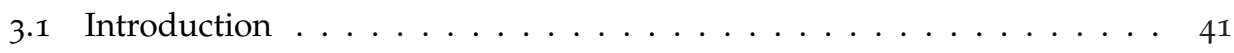

3.2 Related literature . . . . . . . . . . . . . . . . . 44

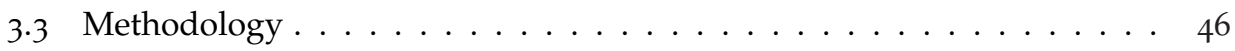

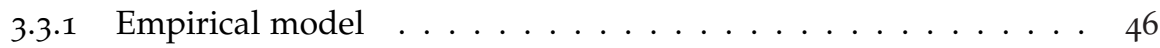

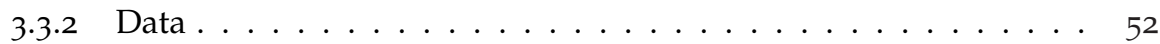

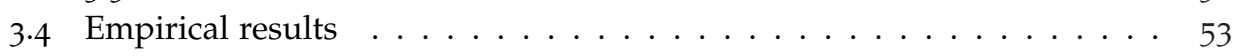

3.4.1 Main results and discussion . . . . . . . . . . . 53

3.4.2 Extensions to sector, size and ownership .......... 56

3.4.3 Extension to industry-level informal competition . . . . . . . 57

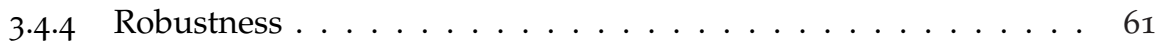

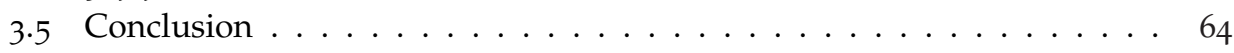

$\begin{array}{ll}\text { References } & 64\end{array}$

$\begin{array}{lll}\text { B } & \text { APPENDIX } & 68\end{array}$ 
4 INFORMAL INNOVATIONS IN URBAN GHANA: DATA SET AND DESCRIPTIVE ANALYSIS $\quad 75$

4.1 Introduction .......................... 75

4.2 Ghana informal innovations data set . . . . . . . . . . . . . . 76

4.2.1 Survey methodology .................. 76

4.2.2 Descriptive statistics ................. 80

4.3 Conclusion .......................... 88

$\begin{array}{ll}\text { References } & 89\end{array}$

$\begin{array}{llr}\text { C APPENDIX } & 92\end{array}$

5 LEARNING AND PRODUCT INNOVATIONS PERFORMANCE IN GHANA: EMPIRICAL STUDY OF INFORMAL ENTERPRISES $\quad 103$

5.1 Introduction ........................ 103

5.2 Related literature ....................... 106

5.2.1 Informality and innovations in SSA . . . . . . . . . . . 106

5.2.2 Learning in SSA .................... 108

5.3 Methodology...................... . . 113

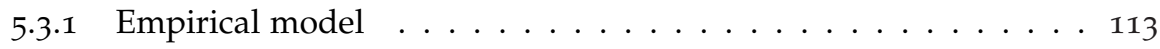

5.3.2 Extensions to model .................. 117

5.3.3 Econometric issues and estimation strategy .......... . 118

5.3.4 Data and descriptive statistics ............... 119

5.4 Empirical results and discussions . . . . . . . . . . . . . . . . 122

5.5 Conclusion ......................... 129

$\begin{array}{lr}\text { References } & 130\end{array}$

$\begin{array}{lrr}\text { D APPENDIX } & 136\end{array}$

6 CONCLUDING REMARKS 139

6.1 Conclusion ........................ 139

6.2 Policy recommendations . . . . . . . . . . . . . . . . . . . . 141

6.3 Limitations and directions for future research . . . . . . . . . . . 142

6.4 Final reflection ........................ . 143

7 VALORISATION ADDENDUM 145

8 AвоUt THE AUthoR $r$ 


\section{LIST OF FIGURES}

Figure 1.1 Growth rate of real GDP per capita in Selected Emerging and SSA Countries. ....................... 2

Figure 1.2 Manufacturing Value Added share of GDP, constant 2010 US Dollars in Selected Emerging and SSA Countries. . . . . . . . 2

Figure 1.3 Economic Complexity Index in Selected Emerging and SSA Countries, 1995-2015. . . . . . . . . . . . . . . 3

Figure $2.1 \quad$ Dose Response Function for total employment (log). . . . . . . . 25

Figure A.1 Simple theoretical relationship between product and process innovations and employment at the firm-level . . . . . . . . . 34

Figure $4.1 \quad$ Heat map of all zones. . . . . . . . . . . . 76

Figure $4.2 \quad$ Aerial maps of selected zones in Accra. . . . . . . . . . . 77 


\section{LIST OF TABLES}

Table 2.1

Descriptive statistics of innovation and employment variables . 22

Table 2.2

Table 2.3

Employment impact of firm-level product innovations . . . . . . 24

Permanent vrs. temporary employment impact of product in-

novations . . . . . . . . . . . . . . . . . 28

Table A.I

First stage estimations for product innovation . . . . . . . . . 35

Table A.2

Population and sample representation of data $\ldots . . . . .38$

Table A.3

Employment impact of firm-level product innovations . . . . . . 39

Table A.4

Table 3.1

Permanent vrs. temporary employment impacts of product innovation . . . . . . . . . . . . . . . . 40

Table 3.2

Description of regions and indicator by country $\ldots \ldots . . .50$

Table $3 \cdot 3$

Table $3 \cdot 4$

Description of 'local' informal competition indicator by country 51

Descriptive statistics of data by country . . . . . . . . . 53

Table 3.5

Effect of informal competition on all product innovations . . . . 54

Sectoral analysis of the effect of informal competition on $\%$ sales, all product innovations . . . . . . . . . . . 58

Table 3.6 Effect of informal competition on \% sales, all product innovations: Domestic ownership . . . . . . . . . . . . . . . . . . 59

Table 3.7 Effect of informal competition on \% sales, all product innovations: Small vrs. medium. . . . . . . . . . . . . . . . . . . . . . .60

Table 3.8 Effect of 'local' and industry-level informal competition on all product innovations . . . . . . . . . . . . . . . 62

Table 3.9 Sectoral analysis of local and industry-level competition on $\%$ sales, product innovations . . . . . . . . . . . . 63

Table B.1 Probit estimation of informal competition as a major constraint 70

Table B.2

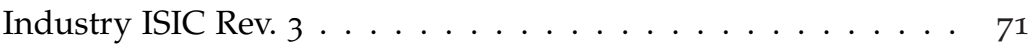

Table B.3 Computed industry-level informal competition by country . . . 72

Table B.4

Table 4.1

Table 4.2

Effect of informal competition on sales from all product innovations ......................... 73

Table $4 \cdot 3$

City, zones and sample sizes . . . . . . . . . . . . . . . 79

Characteristics of informal enterprises ......... 81

Table 4.4

Innovation activities of informal enterprises . . . . . . . . . 83

Examples of innovations . . . . . . . . . . . . . 84

Table 4.5

Employment activities of informal enterprises, 2013-2015 . . . . 86

Table 4.6

Obstacles to informal enterprise operations . . . . . . . . . . 87

Table 4.7

Reasons for informality . . . . . . . . . . . . . . . . . 88

Table 5.1

Description of data . . . . . . . . . . . . 121

Table 5.2

Effect of interaction and apprenticeship on product innovation . 124 
Table 5.3 Effect of competition, collaboration and apprenticeship on product innovation . . . . . . . . . . . . . . . . 127

Table D.1 Estimation outputs for formal interaction and apprenticeship . 138 



\section{INTRODUCTION AND MOTIVATION}

$\neg ح^{\text {HE }}$ development trajectory of most African economies remains wrought with pertinent issues such as the over-reliance on natural resources, low productivity, and persistent poverty, among many others. Some of these issues are being worsened, in recent years, by the demographic pressure and increasing unemployment and underemployment -particularly youth unemployment - glaring on the continent. While development paradigm favours industrialisation as the engine of growth generated through value addition and product sophistication, evidence of deindustrialisation in Africa, however, question industrialisation and the feasibility of the industrial sector generating and equitably distributing 'quality' growth required for rapid economic development in Africa (Szirmai, 2012; Szirmai et al., 2013; Tregenna, 2009). Comparing economic indicators such as growth rate of GDP per capita, manufacturing value added in share of GDP at constant 2010 United States dollars and economic complexity index $(\mathrm{ECI})^{1}$, the evidence becomes apparent. Figures 1.1 and 1.2 show majority of selected sub-Saharan Africa (SSA) economies as well as the SSA average lagged behind other emerging Asian economies such as China, India and Vietnam, particularly after 2010. The Democratic Republic of the Congo (DRC), for instance, had a manufacturing value added share in GDP of about $32 \%$ in 2000 , but experienced a sharp decline since 2009 (about $16 \%$ in 2015). ${ }^{2}$ Figure 1.3 further indicates that in addition to the declining manufacturing value added share in GDP, the ECI also remains comparatively low in SSA. Vietnam, for instance, had an ECI of -1.08 in 1995 below that of both South Africa and Zambia. In 2015, Vietnam's ECI climbed to about -0.22 indicating a tremendous improvement in the sophistication of export products from Vietnam. ${ }^{3}$

I The ECI measures the diversity of a country's productive structure and capabilities using products exported (Hidalgo and Hausmann, 2009).

2 This sharp decline may be as a consequence of the 2008 financial crisis leading to the fall in demand for DRC's natural resources. Political instability in DRC may also be a factor.

3 South Africa since 1998 experienced decline with the 2015 ECI of -0.14, just above that of Vietnam $(-0.22)$. 


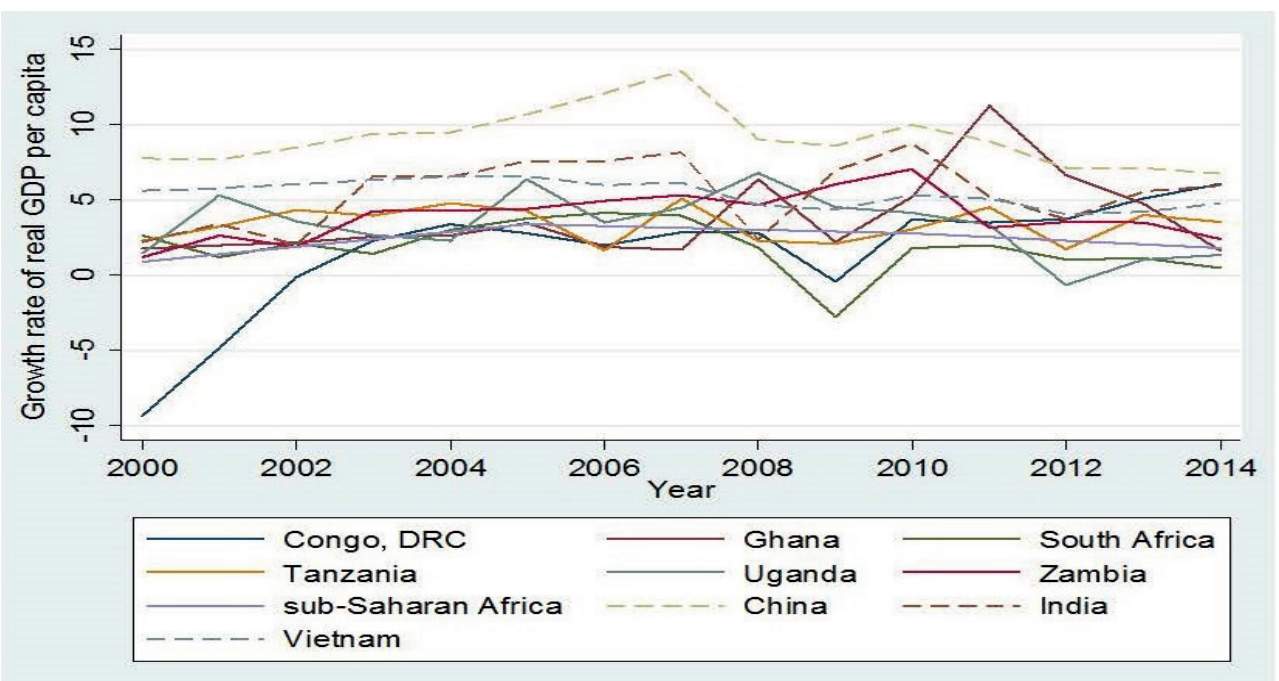

Figure 1.1: Growth rate of real GDP per capita in Selected Emerging and SSA Countries. Source: Sustainable Development Indicators, United Nations Statistics Division; Own representation.

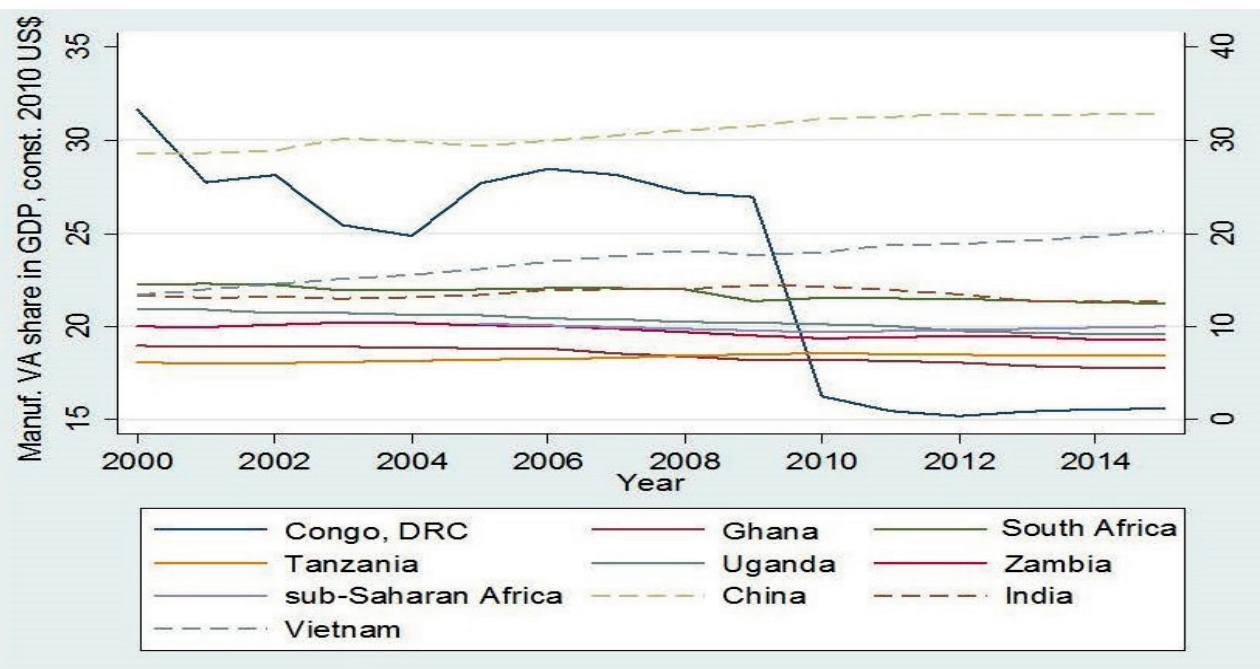

Figure 1.2: Manufacturing Value Added share of GDP, constant 2010 US Dollars in Selected Emerging and SSA Countries.

Source: Sustainable Development Indicators, United Nations Statistics Division; Own representation. 


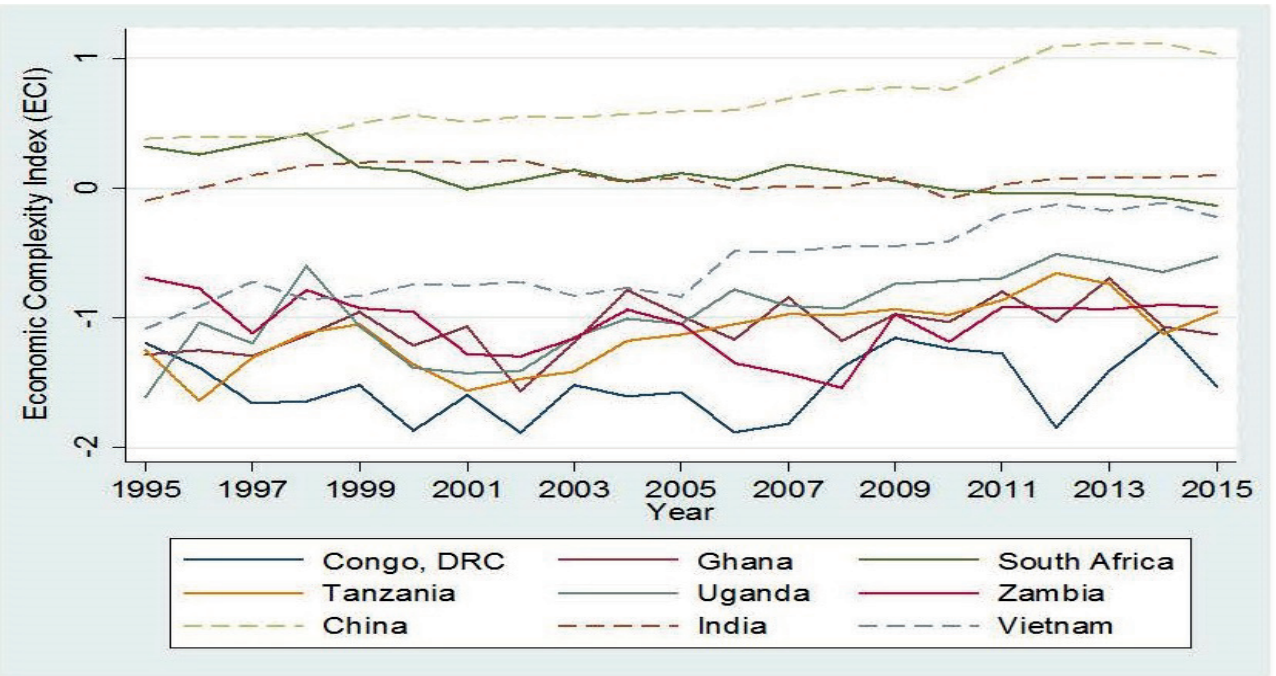

Figure 1.3: Economic Complexity Index in Selected Emerging and SSA Countries, 1995-2015. Source: The Atlas of Economic Complexity, 2017: Harvard Center for International Development; Own representation.

Africa's recent growth optimism has lost steam without yielding the expected structural transformation. The prospect of sustainable growth, therefore, looks dim once again across the continent with decline in global prices of natural resources and the inability of the recent growth process to impact African economies through decent employment creation that may lead to poverty reduction. A major reason often cited, among others, is the low innovativeness of African firms. Firm-level innovations are critical because of the wide recognition that innovation activities drive product sophistication leading to competitiveness and economic progress of national economies, in general. Empirical evidence indicates the critical role firm-level innovations played in leapfrogging productivity, industrial competitiveness and economic prosperity in the 'so-called' newly developed countries of South Korea, Singapore, Malaysia and, most recently, China. Understanding the role firm-level innovations play in spurring sustainable growth in Africa, therefore, becomes fundamental to the development process. 4

Consequently, innovation policies to promote 'innovation-led growth' have gained dramatic interest in Africa, over the last decades. This gradual shift in 'development thinking' occured in parallel with growth spurs experienced by several African countries in the 200os. At the turn of the millennium, for instance, a renewed policy interest emerged at all levels of governance seeking to nurture, promote and generate

4 Innovation is defined broadly following the OECD and Eurostat (2005) as the 'implementation of a new or significantly improved product (good or service), or process, a new marketing method, or a new organizational method in business practices, workplace organization or external relations' [paragraph 146]. 
economic prosperity that offers opportunities for private sector expansion through Science, Technology and Innovation (ST\&I). One such continental policy is the implementation of the New Partnership for Africa's Development (NEPAD) African Science, Technology and Innovation Indicators (ASTII) (NEPAD-ASTII) Initiative in 2007, aimed at collecting and making available useful and reliable ST\&I indicators and statistics across several African countries (AU-NEPAD., 2014, 2010). Indicators and statistics from the initiative are aimed to provide some understanding and support for formulating evidence-based policy decisions. 5 There are currently 35 participating member countries increasing from 19 in the first phase (AU-NEPAD., 2014) ${ }^{6}$ Recognising the critical role of ST\&I in the transformation of the continent, the African Union (AU), in 2014, adopted a 10-year strategy called the 'Science, Technology and Innovation Strategy for Africa 2024 (STISA-2024)'. STISA-2014 is part of the AU Agenda 2063, a bold and an ambitious long-term vision of the AU, launched in 2013. These renewed policy efforts place and reinforce innovation, in part, as a sine qua non in Africa's short-term and long-term socio-economic development.7

Despite the growing policy attention and the empirical literature analysing the relationship between firm innovations and economic indicators such as employment (Mendi and Costamagna, 2017; Konte and Ndong, 2012; Gebreeyesus, 2011; Robson et al., 2009; Goedhuys, 2007; Mahemba and Bruijn, 2003) and productivity (Fu et al., 2017; Mahemba and Bruijn, 2003) in SSA, the evidence remains unclear (AU-NEPAD., 2014). Several critical questions have also received little attention in the literature. How can capacity of firms be enhanced in order to engage in innovation activities? As new frontier technologies emerge with profound prospects for the global economy, how can African firms learn to use and adapt these technologies into local context? How do informal enterprises learn to innovate? How do the symbiotic interactions between 'formal' and 'informal' firms affect innovation activities? Understanding these issues could be instrumental in the formulation of innovative policies that confront key challenges Africa faces. Hitherto, policy discussions on innovation and innovation-led growth in SSA have been largely based on limited empirical evidence, and tend to neglect an integral and significant part of SSA economies.

Motivated by the fact that innovations in SSA may differ in nature from what is known in developed and other developing economies, the purpose of this thesis is to understand the context and consequences of introducing new products on the performance of firms in both the 'formal' and 'informal' sectors. This thesis, therefore, provokes debate and contributes to the understanding of the innovation process in

5 The data collection procedures are based on the Oslo and the Frascati Manuals (see AU-NEPAD. (2014)).

6 Participating member countries in the phase are: Algeria, Angola, Burkina Faso, Cameroon, Egypt, Ethiopia, Gabon, Ghana, Kenya, Lesotho, Malawi, Mali, Mozambique, Nigeria, Senegal, South Africa, Tanzania, Uganda and Zambia. Benin, Botswana, Burundi, Cape Verde, Chad, Congo, the Democratic Republic of Congo, Equatorial Guinea, Liberia, Mauritius, Namibia, Niger, Rwanda, Togo, Tunisia and Zimbabwe joined the second phase of the initiative (see AU-NEPAD. (2014)).

7 See DeGhetto et al. (2016) and lizuka et al. (2015), for summaries and discussions of these new strategies. 
SSA as a whole. It addresses a fundamental aspect of the development puzzle in SSA by recognising the dual economic structure of the region. Each of the chapters outline the arguments made by focusing on the main research gaps, the objectives and the contributions to the respective literature.

In line with these, the second chapter empirically examines the impact of product innovations on total employment for 5 SSA countries. Innovation has become a key interest in SSA, in recent years, as it is evidenced to be pervasive and plays eminent role in generating employment. There is, however, dearth of empirical evidence assessing the impact of product innovations on firm employment in SSA. Using the Dose Response Model under continuous and heterogenous responses to treatment, and data from the recent waves of the Enterprise Survey (ES) merged with Innovation Follow-Up Survey, the main result reveals positive impact of product innovations on total employment. This result is, however, found to hold only at specific intervals of product innovation intensities. The analysis also reveals that product innovations tend to create both temporary and permanent jobs. However, the positive impact of product innovations on temporary employment tends to outweigh that of permanent employment, leading to questions about the security the new jobs offer.

Product market competition is argued to enhance the innovation activities of firms (Blundell et al., 1999). In SSA, interactions between formal and informal businesses in product markets continue to grow in the face of increasing informality. Firm-level evidence, however, reveals the product market competitive behaviour of informal enterprises as 'unhealthy' and one of the top three obstacles formal businesses face in SSA. With scant empirical evidence available, the third chapter fills the gap in the literature by investigating the relationship between informal product market competition and sales from innovative products introduced by formal firms for 5 SSA countries. The main results show that local informal competition has a negative effect on the performance of product innovations while industry informal competition has a positive effect on product innovation. Both local and industry levels of informal competition were, however, found to have no effect on the probability of introducing product innovations. Our analysis also reveals that firms with larger market share perform better in product markets that are highly informal.

The informal economy has grown over the last decades in SSA. As a result, the innovation activities of informal enterprises in the region have gained some research interest. Understanding innovation activities of informal enterprises may provide insight into innovations in Africa (Kraemer-Mbula and Wunsch-Vincent, 2016). There is, however, lack of data on the innovation activities of informal enterprises. The fourth chapter, therefore, presents detailed descriptive statistics from a survey conducted in urban Ghana (Accra and Tema) on 513 informal enterprises in June 2016. The survey's overarching goal was to gather information on the type of innovations informal enterprises use and adapt to answer customers' changing needs and demands. The survey also sought to understand the role of networks and apprenticeship in learning, adopting and adapting innovations in the informal economy. For design advantages, the 
study used zones identified in the World Bank's Ghana Informal Enterprise Survey (GIFS) as area-based frame. Randomly selecting 17 of these zones and canvassing each selected zone, the study was able to identify informal enterprises. Face-to-face interviews were then conducted using semi-structured questionnaire coded on electronic data collection software, specifically SurveyCTO, covering a host of topics of interest. The results show that innovations are widespread in sampled informal enterprises.

The fifth chapter further explores the innovation activities of informal enterprises. The role of knowledge, technology adoption and adaptation in accelerating economic progress in developing countries is widely emphasised in development economics. Local capability development and enhancement through learning is touted to be critical in this process (Cohen and Levinthal, 1989; Lall, 2000; Kraemer-Mbula and Wamae, 2010; Romijn, 2002). Empirical evidence examining the effect of learning processes on the innovation activities of informal enterprises in SSA, however, remains scant and anecdotal. This chapter examines the effect of apprenticeship and formal interactions on the innovation performance of informal enterprises in Ghana, using a unique survey data on 513 enterprises. The analysis reveals a significant and positive effect of apprenticeship and formal interaction on the innovation performance of informal enterprises. Decomposing formal interaction, the results indicate that enterprises with competitive formal interaction tend to have a strong positive effect on innovation performance while enterprises with collaborative formal interaction have strong negative effect. The results also show apprenticeship improves technological capabilities of enterprises leading to product innovativeness whereas competitive formal interactions provide essential domestic market signal that enhances the innovativeness and the performance of product innovations of enterprises.

This thesis is, therefore, presented in six chapters including the general introduction and concluding remarks in the first and last chapters respectively. 


\section{REFERENCES}

AU-NEPAD. (2010). African Innovation Outlook 2010. Technical report, African Union-New Partnership for Africa's Development, Pretoria, South Africa.

AU-NEPAD. (2014). African innovation outlook II. Technical report, African UnionNew Partnership for Africa's Development, Pretoria, South Africa.

Blundell, R., Griffith, R., and Van Reenen, J. (1999). Market Share, Market Value and Innovation in a Panel of British Manufacturing Firms. The Review of Economic Studies, 66(3):529-554.

Cohen, W. M. and Levinthal, D. A. (1989). Innovation and Learning: The Two Faces of R \& D. The Economic Journal, 99(397):569-596.

DeGhetto, K., Gray, J. R., and Kiggundu, M. N. (2016). The African Union's Agenda 2063: Aspirations, Challenges, and Opportunities for Management Research. Africa Journal of Management, 2(1):93-116.

$\mathrm{Fu}, \mathrm{X} ., \mathrm{Mohnen}, \mathrm{P}$. , and Zanello, G. (2017). Innovation and productivity in formal and informal firms in Ghana. Technological Forecasting and Social Change, $\mathrm{xxx}(\mathrm{xxxx}): \mathrm{xxx}-$ $\mathrm{xxx}$.

Gebreeyesus, M. (2011). Innovation and Microenterprise Growth in Ethiopia. In Szirmai, A., Naudé, W., and Goedhuys, M., editors, Entrepreneurship, Innovation, and Economic Development, pages 122-146. Oxford University Press.

Goedhuys, M. (2007). Learning, product innovation, and firm heterogeneity in developing countries; Evidence from Tanzania. Industrial and Corporate Change, 16(2):269292.

Hidalgo, A. C. and Hausmann, R. (2009). The building blocks of economic complexity. PNAS, 106(26):10570 -10575.

Iizuka, M., Mawako, P., and Gault, F. (2015). Innovation for Development in Southern and Eastern Africa: Challenges for Promoting ST\&I Policy. UNU-MERIT Policy Brief 1 .

Konte, A. and Ndong, M. (2012). The informal ICT sector and innovation processes in Senegal. African Journal of Science, Technology, Innovation and Development, 4(3):61-97.

Kraemer-Mbula, E. and Wamae, W. (2010). Innovation and the Development Agenda. OECD Publishing. 
Kraemer-Mbula, E. and Wunsch-Vincent, S. (2016). Introduction. In Kraemer-Mbula, E. and Wunsch-Vincent, S., editors, The Informal Economy in Developing Nations: Hidden Engine of Innovation?, pages 1-12. Cambridge University Press, Cambridge.

Lall, S. (2000). Skills, Competitiveness and Policy in Developing Countries. Comparative and General Pharmacology, (46):1-29.

Mahemba, C. M. and Bruijn, E. J. D. (2003). Innovation Activities by Small and Medium-sized Manufacturing Enterprises in Tanzania. Creativity and Innovation Management, 12(3):162-173.

Mendi, P. and Costamagna, R. (2017). Managing innovation under competitive pressure from informalproducers. Technological Forecasting and Social Change, 114:192202.

OECD and Eurostat (2005). Oslo Manual. Guidelines for collecting and interpreting innovation data. Organisation for Economic Co-operation and Development, Paris, 3rd edition.

Robson, P. J. A., Haugh, H. M., and Obeng, B. A. (2009). Entrepreneurship and innovation in Ghana: Enterprising Africa. Small Business Economics, 32(3):331-350.

Romijn, H. (2002). Small Enterprise Development in Developing Countries: Innovation or Acquisition of Technological Capability? In van Dijk, M. P. and Sandee, H., editors, Innovation and Small Enterprises in the Third World, chapter 2, pages 15-47. Edward Elgar Publishing, Inc., Cheltenham, UK.

Szirmai, A. (2012). Industrialisation as an engine of growth in developing countries, 1950-2005. Structural Change and Economic Dynamics, 23(4):406-420.

Szirmai, A., Gebreeyesus, M., Guadagno, F., and Verspagen, B. (2013). Promoting Productive Employment in Sub-Saharan Africa . A Review of the Literature. UNUMERIT Working Papers Number 62, Maastricht, The Netherlands.

Tregenna, F. (2009). Characterising deindustrialisation: An analysis of changes in manufacturing employment and output internationally. Cambridge Journal of Economics, 33(3):433-466. 


\section{2}

EMPLOYMENT IMPACT OF PRODUCT INNOVATIONS IN SUB-SAHARAN AFRICA: FIRM-LEVEL EVIDENCE

\subsection{INTRODUCTION}

$\mathrm{I}$

NNOVATION remains widely recognised as a primary driver of economic growth and productivity as well as a major source of employment (Fagerberg et al., 2005; Schumpeter, 1934; van Dijk and Sandee, 2002; Verspagen, 1992). Firm-level innovations, in particular, have been found to create new jobs (Harrison et al., 2014; Hall et al., 2008; Pianta, 2005). Advancing firm-level innovations and promoting firm-level innovation activities arguably offer strong prospects for sustainable growth, improvement in productivity and consequently avenues for quality employment creation in developing countries, particularly in sub-Saharan Africa (SSA) (Gault, 2010).

The effects of firm-level innovations and innovation activities have also been argued to be key in resolving some of the challenges Africa faces today and thus an important policy and research area (AU-NEPAD., 2010). Despite policy efforts, ${ }^{1}$ little remains known about the relationship between innovation and employment in Africa. According to AU-NEPAD. (2014), one challenge facing African countries is how to 'link' innovation to employment creation. The ample empirical literature examining the effect of innovation on employment remains mixed. As a result, empirical analysis of the relationship still occupies centre stage in the development literature (Peters, 2005). The innovation-employment literature also mainly focuses on manufacturing firms in developed countries, largely ignoring innovations in the service sector. ${ }^{2}$ With innovation in the service sector evidently exerting more beneficial effects on employment than in manufacturing (Gallouj and Djellal, 2010) and being the major contributor to GDP in most SSA economies, it is critical to consider and analyse the innovation activities of service sector firms. Examining the context of innovations and the direct and indirect mechanisms through which it affects employment at the firm-level is important for both innovation and employment policies (Hall et al., 2008).

It is in the spirit of closing these evidence gaps and contributing to the understanding of how innovations impact employment that this chapter becomes vital. This chap-

1 Lagos Plan, Khartoum declaration, Addis Ababa declaration, etc.

2 Notable exceptions include Harrison et al. (2014) and Gebreeyesus (2011). 
ter sheds light on the relevance of product innovations in the design of policies for employment in SSA. The chapter contributes to the literature in three major ways. Firstly, it contributes to the thin empirical literature in SSA by assessing the impact of firmlevel product innovations on total employment, using a newly available firm-level data. Scholarly evidence available in the literature is mainly from developed countries and Latin America. This may be partially due to the scarce firm-level innovation data in SSA. With the availability of some innovation data in recent years, this chapter contributes to the literature by providing empirical evidence that helps to better understand product innovations and its labour market implications in SSA. Secondly, the chapter goes beyond the correlation analyses popular in the literature by employing a novel counterfactual perspective where innovative firms are assumed to have varying responses to intensity of product innovations. In modern micro-econometrics, counterfactual causal analysis is becoming widespread in establishing causal relationships between economic variables. However, the application of causal analysis remains missing in the innovation-employment literature. We model in this chapter a firm's choice to introduce innovation or otherwise, and rigorously examine the impact of firm-level product innovations on employment under heterogeneous responses with varying intensities. This approach provides a deeper understanding of the causal relationship and determines whether there is (are) product innovation intensity (ies) where total employment is maximised (or minimised). Thirdly, the creation (compensation) and destruction (displacement) impact of product innovations may depend on the type and skill of workers (Harrison et al., 2014). This chapter makes another important contribution to the literature by extending our analysis to understand the different impacts product innovations may have on decent employment, specifically on the security of employment.

In this chapter, we adapt and apply the Dose Response treatment econometric model recently developed by Cerulli (2015). The chapter uses comparable Enterprise Survey (ES) merged with Innovation Follow-Up Survey for Congo Democratic Republic (DRC), Ghana (GH), Tanzania (TZ), Uganda (UGA) and Zambia (ZAM). Estimation results reveal compensation impact of product innovations on total employment. This conclusion is, however, found to be valid only within a sub-interval of firms' intensity of product innovations. Regarding decent employment, we find product innovations to be creating more temporary jobs as compared to permanent jobs.

The rest of the chapter is organised into the following sections. Section 2.2 presents a brief literature review on the relationship between innovation and employment. In Section 2.3, the Dose Response Treatment Model and sources of data are presented. Section 2.4 presents the results and discussions in line with the objectives of the chapter. We present our concluding remarks and recommendations in Section 2.5. 


\subsection{RELATED LiterATURE}

Development economics, by tradition, recognises innovation as a major driver of economic growth and a source of employment generation (Dosi et al., 1988; Fagerberg et al., 2005; Schumpeter, 1934; Verspagen, 1992, for a survey). ${ }^{3}$ Conceptually, the theoretical analyses of the effect of innovation on employment are done from either the micro or macro strand or both (Pianta, 2005; Vivarelli, 2014). This review concentrates on the micro strand because innovations are introduced at the firm-level where their employment effects are manifested directly (Pianta, 2005).

The theoretical literature analysing the employment effects of innovation, essentially, classifies innovations into two main types: product and process. ${ }^{4}$ This distinction is, however, not strict as complementarity is found to exist between the two types of innovations (Mohnen and Hall, 2013; Mairesse and Mohnen, 2010; Pianta and Antonucci, 2002). ${ }^{5}$ The overall (direct and indirect) effects of both types of innovations on employment at the firm-level is still theoretically contrasting and ambiguous (Hall et al., 2008; Pianta and Antonucci, 2002; Lachenmaier and Rottmann, 2011). Process innovation is anticipated to improve the efficiency of the production process with cost cutting effects leading to the employment of fewer workers. As a result, the direct effect of process innovation on employment is expected to be negative, referred to as the 'displacement effect'. There exist an indirect effect as well. A firm that introduces a process innovation is expected to be more efficient, become more cost competitive and thereby raise its productivity level. The increase in productivity level can be passed on to customers as lower prices in competitive markets thereby stimulating demand and thus employment of additional workers, ceteris paribus. This is referred to as the 'compensation effect'. The size of the compensation effect, however, depends on the elasticity of demand for the firm's products, behaviour of agents in the firm as well as competition from other firms (Harrison et al., 2014). The total effect of process innovation on employment at the firm-level is, therefore, inconclusive as the compensation effect may outweigh the displacement effect and vice versa.

Product innovation, on the other hand, is intended to make firms more technologically competitive (Pianta and Antonucci, 2002; Bogliacino and Pianta, 2010). The improved competitiveness is expected to lead to the introduction of 'new' products on the market through quality advantages thereby stimulating economic activity and market expansion and hence employment (Pianta and Antonucci, 2002). This enables a direct positive relationship between innovation and employment. However, the market expansion that enables the positive direct effect could be a result of displacement

3 See Calvino and Virgillito (2018, for a recent survey of the literature).

4 See OECD and Eurostat (2005, paragraphs 156 \& 168) for broad definitions of product and process innovations respectively.

5 See Figure A.1 in appendix for the graphical representation of this theoretical relationship. 
(crowding-out effect) of other less competitive firms in the industry. ${ }^{6}$ The effect of product innovation is, therefore, theoretically unclear and inconclusive.

The theoretical effect of introducing both types of innovations on employment depends on the size of the compensation and displacement effects emanating from both types of innovations. If product innovations have a larger compensation (positive) effect as compared to the displacement (negative) effect from process innovations, joint introduction of both types of innovations will be expected to generally have compensation (positive) effect on employment and vice versa. The effect of innovations on employment also extend beyond the firm-level and may be found at the industry level and even beyond. These indirect effects may result from the competitive redistribution of output and demand due to changes in relative prices as well as input-output relations between firms in an industry. Firms may also adopt innovations generated in other industries leading to employment impacts (Pianta, 2005; Verspagen, 2004). This is, however, beyond the scope of this chapter.

Despite the ambiguity in the theoretical literature, there exists some level of general consensus in the empirical literature about the relationship between product innovations and employment at the firm-level (Vivarelli, 2014; Pianta, 2005, for recent survey of the literature). Copious empirical works in the literature find positive effect of product innovations on employment (Harrison et al., 2014; Meriküll, 2010; Peters, 2008; Hall et al., 2008; Piva et al., 2005). Harrison et al. (2014) analysed the stimulating effects of innovation on employment using innovation survey data on both manufacturing and service sector firms in France, Germany, Spain and the United Kingdom. The authors developed a simple theoretical framework that disentangles the effect of innovation (product and process) on output growth and employment growth from existing products. The authors assumed both process and product innovating firms to be product innovators as both innovations 'correspond to the introduction of new products.' The major finding emanating from the empirics is that product innovation is a major source of employment and the compensation effects from it far outweigh the displacement effect from process innovation. Peters (2008), Hall et al. (2008), Crespi and Tacsir (2013) and de Elejalde et al. (2015), using different adapted versions of the Harrison et al.(2014) earlier model, found similar results. Using a panel data from Italian manufacturing firms, Hall et al. (2008) found a crowding-out effect resulting in the cancellation of the positive employment growth obtained from product innovation. Crespi and Tacsir (2013) and de Elejalde et al. (2015) analysed the effect of product and process innovations on employment in Latin America using innovation survey data focusing on the manufacturing industry. The authors found product innovations to be skill-biased especially in high-tech manufacturing firms. Further analysis by de Elejalde et al. (2015) indicates that product innovation is skill biased but creates both skilled and unskilled jobs.

6 The crowding-out effect is, however, captured at firm-level analysis if firms in the dataset are representative of the industry (see Harrison et al.(2014)). 
Empirical evidence analysing the relationship between innovation and employment in SSA is scant. The idiosyncratic nature of innovation in SSA, coupled with the structural features of innovation might lead to invalid extrapolation of results from other regions. The known empirical evidence available includes Gebreeyesus (2011) and Konte and Ndong (2012). Using secondary survey data on informal micro-enterprises in Ethiopia, Gebreeyesus (2011) found innovation activities to contribute to employment growth. The author also found no bi-directional causality from employment growth to innovation. In a rare descriptive study that collected primary data on informal Information and Communication Technology (ICT) firms in Senegal, Konte and Ndong (2012) found innovation as a contributor to job creation and economic growth. The chapter adds to this thin literature by presenting a cross-country firm-level analysis using data from 5 SSA economies.

\subsection{METHODOLOGY}

\subsubsection{Theoretical and empirical models}

The Dose Response Model (DRM) employed in this chapter is an econometric model for estimating continuous treatments under heterogeneous responses, where selection into treatment may be endogenous (Cerulli, 2015). A firm's decision to innovate may not be random and may be influenced by confounders and vice versa. Cerulli and Poti (2014) applied the methodology (the first application to real data) to analyse the impact of public support intensity and firm R\&D performance. ${ }^{7}$ A variant model was also developed and used by Imbens and Hirano (2004), with Fryges and Wagner (2008) applying the Imbens and Hirano (2004) model to investigate the relationship between exports and productivity growth. The choice of the Dose Response Model under continuous treatment is based on its non-requirement of full normality and its applicability to data where lots of firms have not introduced any type of innovation and vice versa (Baum and Cerulli, 2016; Cerulli, 2015; Cerulli and Poti, 2014).

The DRM, however, assumes a specific functional form and jointly normally distributed error terms. One other criticism of the DRM, as noted by Cerulli (2015), is that the IV estimator is 'inconsistent in finite samples.' Due to the spike in our data, that is, a large number of non-innovators, estimates from our empirical analyses may have a bias. We, however, tried to improve the consistency of our results by merging 2 related data sets and appending all observations across 5 countries. The consistency of the IV estimator is found to improve as the sample size gets larger (Cerulli, 2015).

7 See Baum and Cerulli (2016) for a recent application. 


\subsubsection{A Description of theoretical model}

Assume there are two exclusive groups of firms: innovative firms (treated) and noninnovative firms (untreated). Let the innovation indicator, $W_{i}=\{0,1\}$ show whether a firm has introduced an innovation $\left(W_{i}=1\right)$ or not, $W_{i}=0$. Firms are assumed to have different product innovation intensities $(t)$ with non-innovative firms having $t=0$. Innovative firms are assumed to take values greater than zero $(t>0)$ as these firms have, within the period under consideration, introduced at least one innovation. $t$ is, therefore, assumed to take values strictly within the continuous range of [o:10o].

Let the employment outcome of an innovative firm (treated) be defined as $y_{1 i}$ and the employment outcome of a non-innovative firm (untreated) be $y_{0 i}$. Employment outcomes are assumed to be exclusive to the firm. Suppose a vector of $M$ confounders as $X=\left\{x_{1 i} \ldots x_{M i}\right\}$ for all firms. Let $N$ refer to the total number of firms, $N_{1}$ refer to the total number of innovative firms and $N_{0}$ be the total number of non-innovative firms with $N=N_{1}+N_{0}$.

Following Cerulli (2015), let the population employment outcomes be written as:

$$
\begin{gathered}
w=1: y_{1}=a_{1}+f_{1}(x)+g(t)+e_{1} \\
w=0: y_{0}=a_{0}+f_{0}(x)+e_{0}
\end{gathered}
$$

where $y_{1}$ and $y_{0}$ are the employment outcomes of innovative and non-innovative firms respectively, $a_{1}$ and $a_{0}$ are two scalars, $f_{1}(x)$ and $f_{0}(x)$ are firms' responses to the vector of confounding variables $(x)$ in terms of innovating versus not-innovating, $g(t)$ measures the responses of employment outcomes to the intensity or the level of product innovations taking a value of 0 if $w=0$ and $\neq 0$ if $w=1$.

Assuming further that $f_{1}(x)$ and $f_{0}(x)$ have a linear parametric form as $f_{1}(x)=x \delta_{1}$ and $f_{0}(x)=x \delta_{0}$, the causal parameters conditional on $x$ and $t$ can be written as: ${ }^{8}$

$$
\begin{gathered}
\operatorname{ATET}(x, t>0)=E\left(y_{1}-y_{0} \mid \mathrm{x}, \mathrm{t}>0\right) \\
\operatorname{ATENT}(x, t=0)=E\left(y_{1}-y_{0} \mid \mathrm{x}, \mathrm{t}=0\right)
\end{gathered}
$$

8 These assume that the treatment effect $(\mathrm{TE})=\left(y_{1}-y_{0}\right)$. 


$$
\operatorname{ATE}(x, t)=E\left(y_{1}-y_{0} \mid \mathbf{x}, \mathbf{t}\right)=\left\{\begin{array}{l}
\left(a_{1}-a_{0}\right)+x\left(\delta_{1}-\delta_{0}\right)+g(t) \text { if } t>0 \\
\left(a_{1}-a_{0}\right)+x\left(\delta_{1}-\delta_{0}\right) \text { if } t=0
\end{array}\right\}=\left\{\begin{array}{c}
a+x \delta+g(t) \text { if } t>0 \\
a+x \delta \text { if } t=0
\end{array}\right.
$$

where $a=\left(a_{1}-a_{0}\right)$ and $\delta=\left(\delta_{1}-\delta_{0}\right)$. ATET and ATENT refer to Average Treatment Effect on the Treated (innovative firms) and Average Treatment Effect on Non-Treated (non- innovative firms) respectively. ATE is defined as the Average Treatment Effect.

Rewriting equation 2.23 conditional on $x, t, w$ gives:

$$
\operatorname{ATE}(x, t, w)=\left\{\begin{array}{ll}
\operatorname{ATE}(x, t>0) & \text { if } w=1 \\
\operatorname{ATE}(x, t=0) & \text { if } w=0
\end{array}=w[a+x \delta+g(t)]+(1-w)[a+x \delta]\right.
$$

By averaging equation 2.31 on $x, t, w$, the unconditional ATE is obtained as:

$$
A T E=E_{(x, t, w)}[\operatorname{ATE}(x, t, w)]=p(w=1)\left(a+\bar{x}_{t>0} \delta+\bar{g}\right)+p(w=0)\left(a+\bar{x}_{t=0} \delta\right)
$$

where $\bar{g}$ is the average response function taken over $t>0 . \mathrm{p}(\mathrm{w}=\mathrm{1})$ is the probability to innovate and $\mathrm{p}(\mathrm{w}=\mathrm{O})$ is otherwise.

Applying the Law of Iterated Expectations (LIE) where ATE $=p(w=1)($ ATET $)+$ $p(w=0)(A T E N T)$, the remaining causal parameters can be rewritten from equation 2.41 as:

$$
\begin{aligned}
& A T E T=a+\bar{x}_{t>0} \delta+\bar{g} \\
& \text { ATENT }=a+\bar{x}_{t=0} \delta
\end{aligned}
$$

Thus, the Dose Response Function (DRF) is derived algebraically by averaging $\operatorname{ATE}(x, t)$ over $x$ as: 9

$$
\operatorname{ATE}(t, w)=E_{x}\{\operatorname{ATE}(x, t, w)\}=w[\operatorname{ATET}+(g(t)-\bar{g})]+(1-w) \operatorname{ATENT}
$$

Equation 2.51 can be re-written as:

9 See Cerulli(2012, p. 7\&8 for proof). 


$$
\operatorname{ATE}(t)=\left\{\begin{array}{c}
\text { ATET }+(g(t)-\bar{g}) \text { if } t>0 \\
\text { ATENT if } t=0
\end{array}\right.
$$

where $\operatorname{ATE}(t)$ is the main causal parameter of interest and defined as the Average Treatment Effect dependent on the intensity or the level of product innovation.

\subsubsection{B Empirical model}

Transforming ${ }^{10}$ and assuming that $g(t)$ is a three degree polynomial, that is, $g(t)=$ $b t+c t^{2}+d t^{3},{ }^{11}$ the estimation equation can be derived as: ${ }^{12}$

$$
\begin{array}{r}
E(y \mid x, w, t)=a_{0}+x \delta_{0}+w A T E+w[x-\bar{x}] \delta+b[t-E(t)] w+c\left[t^{2}-E\left(t^{2}\right)\right] w \\
+d\left[t^{3}-E\left(t^{3}\right)\right] w+\varepsilon
\end{array}
$$

where $\varepsilon=e_{0}+w\left(e_{1}-e_{0}\right) . y$ is employment outcome of firms. ATE indicates the average causal effect of introducing product innovations on employment. $w[x-\bar{x}] \delta$ captures the heterogeneous average deviations of exogenous confounders from their means. Equation (2.61) estimates the average employment responses to product innovations (ATE) while controlling for exogenous factors $(x)$ as $x$ and the intensity of product innovations $(t)$ deviate from their means. Under Conditional Mean Independence (CMI), OLS estimation of equation (2.61) is argued to provide consistent estimates of the parameters of interest (Cerulli, 2015, 2014).

The Dose Response Function can be estimated as:

$$
\begin{aligned}
& \left.\widehat{\operatorname{ATE}\left(t_{i}\right.}\right)=w\left[\widehat{\operatorname{ATET}}+\hat{b}\left(t_{i}-\frac{1}{N} \sum_{i=1}^{N} t_{i}\right)+\hat{c}\left(t_{i}^{2}-\frac{1}{N} \sum_{i=1}^{N} t_{i}^{2}\right)+\hat{d}\left(t_{i}^{3}-\frac{1}{N} \sum_{i=1}^{N} t_{i}^{3}\right)\right] \\
& +(1-w) \widehat{A T E N T}
\end{aligned}
$$

where $\left.\widehat{\operatorname{ATE}\left(t_{i}\right.}\right)$ is a consistent Dose Response Function with $\left.\widehat{\operatorname{ATE}\left(t_{i}\right.}\right)=\operatorname{ATE}\left(t_{i}\right)_{t_{i}>0}$. $\widehat{A T E T}$ and $\widehat{A T E N T}$ refer to the estimated Average Treatment Effect on the Treated

10 The transformation is done by substituting equations 2.21 and 2.22 into the Potential Outcome Model (POM), $y=y_{0}+w\left(y_{1}-y_{0}\right)$.

11 According to Cerulli (2012) and Cerulli and Poti (2014), g (t) can be assumed to have linear, partial linear or polynomial regression forms. We assumed a polynomial regression form here to control for possible non-linearity of the intensity of product innovation. We checked the robustness of our results by also assuming a linear regression form.

12 Cerulli (2012, p. 8\&9 for proof). 
(innovative firms) and the estimated Average Treatment Effect on Non-Treated (noninnovative firms) respectively.

Empirical evidence from the innovation literature indicates that the decision to innovate or not $(w)$ and the intensity or the level of product innovation $(t)$ are likely to be endogenous (see Harrison et al. (2014)). ${ }^{13}$ The assumption of Conditional Mean Independence (CMI), therefore, breaks down and estimation of equation (2.61) with OLS gives biased estimates. That is, $E(\varepsilon \mid x, w, t) \neq E\left(e_{0}+w\left(e_{1}-e_{0}\right) \mid x, w, t\right)$ (Cerulli, 2014, p. 9). Following Cerulli (2015), equation (2.61) is re-written as an estimation equation as:

$$
\begin{gathered}
y=a_{0}+x \delta_{0}+w A T E+w[x-\bar{x}] \delta+b w T_{1}+c w T_{2}+d w T_{3}+\varepsilon_{y} \\
w=\left\{\begin{array}{c}
1 \text { if } w^{*}=\eta_{1} x_{1}+\varepsilon_{w}>0 \\
0 \text { if } w^{*} \leq 0
\end{array}\right\} \\
t=\left\{\begin{array}{c}
\eta_{2} x_{2}+\varepsilon_{t} \text { if } w^{*}>0 \\
0 \text { if } w^{*} \leq 0
\end{array}\right\}
\end{gathered}
$$

where $T_{1}=[t-E(t)], T_{2}=\left[t^{2}-E\left(t^{2}\right)\right]$ and $T_{3}=\left[t^{3}-E\left(t^{3}\right)\right]$ are considered to be endogenous together with $w . \varepsilon_{y}$ is an error term with zero mean and constant variance. $y$ refers to total emploment $(\log ) . \delta$ is the average heterogeneous employment among product innovators due to deviations from main cities of business and also serves as an additional exclusion restriction (see Baum and Cerulli (2016)). $w^{*}$ is the unobservable latent variable of innovative and non-innovative firms. The intensity of product innovation is only observed when a firm introduces an innovation $(w=1)$, otherwise it is assumed to be unobserved (Amemiya, 1985, p. 384 \& 385). Equations (2.72) and (2.73) are specified as a Type II Tobit model (Amemiya, 1985) where (2.72) shows the selection equation with $x_{1}$ as a vector of covariates that influences the decision of a firm to innovate or not, while (2.73) defines the vector of covariates $x_{2}$ that determines the intensity of product innovation. Covariates included in $x_{1}$ and $x_{2}$ are suggested by the recent empirical literature including Gebreeyesus (2011) and Classen et al. (2014).

From equation 2.71, we are not only interested in the direct impact of product innovation (ATE) on total employment, but also how this impact is mediated by the intensity of product innovation given other covariates. $b, c$ and $d$ capture these heterogeneous effects of product innovation on total employment due to deviations of innovation intensities from their means. While the theoretical and empirical evidence from the innovation-employment literature suggest that product innovation (ATE) should have a positive impact on employment (Harrison et al., 2014; Meriküll, 2010; Peters,

13 Test results using the Durbin and Wu-Hausman statistics confirmed the problem of endogeneity. 
2008; Piva et al., 2005), we hypothesise that this positive impact is conditioned on product innovation intensities.

\subsubsection{Estimation/Identification procedure}

The estimation in this chapter can be performed in two stages. The first stage involves a Maximum Likelihood (ML) estimation of the Type II Tobit model of equations (2.72) and (2.73). Fitted values from the first stage ML estimation of equations (2.72) and (2.73) are obtained and used as instruments in equation (2.71) for a two stage least squares (2SLS) estimation (Cerulli, 2015; Wooldridge, 2013, p. 529).

The second stage estimation, in addition to the possible endogeneity problem, poses issues of parameter identification as equation (2.71) is assumed to have the same covariates in the Type II Tobit model. To resolve these issues, we extend the identification assumption by Cerulli $(2015,2014)$ to specify the vector of covariates in equations (2.72) and (2.73) as:

$$
\begin{aligned}
& x_{1}=\left(x, q_{1}\right) \\
& x_{2}=\left(x, q_{2}\right)
\end{aligned}
$$

where $q_{1}, q_{2}$ are vectors of variables that appear and explain the probability of a firm to innovate and the intensity of product innovations respectively, thereby satisfying the exclusion restriction (Wooldridge, 2013).

One difficulty in using IV, as well established in the econometric literature, is the identification of valid instruments. The theoretical and empirical literature on employment and innovation have, however, suggested several instruments that have been found to minimise the problem of endogeneity (see among others Harrison et al., 2014; Crespi \& Tacsir, 2013; Elejalde et al., 2013; Hall et al., 2008 and Peters, 2008). Some of the identified instruments include: increased range, clients as source of information, continuous external R\&D engagement (see Harrison et al., 2014; Hall et al., 2008); R\&D intensity, share of market, internal R\&D, patent, science (see Peters, 2008); public support for innovation activities (see Crespi \& Tacsir, 2013). Intuitively checking the relevance and validity of these instruments for which we have data on, we identified license and patent as instruments for product innovation intensity and product innovation respectively. Both license and patent are innovation activities performed outside of the firm and are not expected to be correlated with firms' total employment. These instruments are, however, expected to have high correlation with our innovation variables. License, for example, comes with risks. In the context, it is believed that firms only acquire a license that is 'successful' and one they have already 'imitated'. Expecting a high market return, they purchase the license to enable them 
sell their 'new', 'imitated' products on the domestic market, leading to high sales of innovative products. First-stage regression results of our innovation variables show strong significance of the set of instruments, indicating their relevance. ${ }^{14}$

The two stages of estimation are performed in this chapter using the conditional mixed process (cmp) econometric package in Stata SE/13.1, which performs ML estimation of the extended equations (2.72) and (2.73) as well as (2.71) jointly rather than the estimation of the two stages explicitly. The choice of joint ML estimation is based on its 'strong consistency and asymptotic normality properties' (Amemiya, 1973). Econometric packages have also been found to be particularly useful in obtaining consistent standard errors and test statistics as compared to the invalid standard errors and test statistics obtained from the 'manual' estimation of both stages (Wooldridge, 2013).

\subsubsection{Data and measurement}

The empirical investigation in this chapter uses data from the Enterprise Survey (ES) and the Innovation Follow-Up Survey of the World Bank. ${ }^{15}$ The ES is a World Bank project that collects enterprise data in 139 countries, with a standard methodology allowing for cross-country comparisons. The ES methodology randomly stratifies firms by sector, size and location thus making the sample in each country representative. The Innovation Follow-Up Survey is a follow-up survey to the ES and collects representative firm-level data on innovation and innovation activities of firms between the last fiscal year and three fiscal years ago. ${ }^{16}$ The Innovation Follow-Up Survey follows the Oslo Manual (OECD and Eurostat, 2005) and covers 19 countries between 2011-2014, out of which 15 of the countries covered are in Africa.

For compatibility of surveys, we considered only countries that conducted the ES and the innovation survey in 2013. ${ }^{17}$ Due to large missing observations for almost all variables of interest, the ES and the Innovation Follow-Up Survey were merged at country level using a unique country identifier. All merged country data sets were then appended using a global unique identifier for larger sample size. Appending all the data sets across countries guarantees a larger sample size and also offers us the rare opportunity to cross-check responses across the 2 surveys. In total, data for 5 SSA countries (DRC, Ghana, Tanzania, Uganda and Zambia) totaling 2,466 firms were obtained.

To standardise our data for cross-country comparison, we converted nominal sales values, for instance, to United States Dollars (USD) using exchange rate data in the corresponding fiscal year from the World Bank's World Development Indicators.

14 See Table A.1 in appendix.

15 Both data sets cover manufacturing and service sector firms.

16 See OECD and Eurostat (2005) for measurement and definition of these concepts.

17 Ethiopia, Rwanda, and Zimbabwe are also excluded as the sampling methodologies employed in the follow up survey differ from the ES global methodology. 
Appendix A.2 provides a detailed definition and measure of all variables used in our analysis. We present below how we measure our key variables.

Innovation: In line with Harrison et al. (2014), among others, we use 2 related measures to capture innovation: product innovation and product innovation intensity. Product innovation is a dummy variable capturing whether a firm introduced any innovative good or service over the last 3 fiscal years, that is, between 2010 and 2012. Product innovation intensity captures the percentage of sales from all product innovations in the last fiscal year (2012). It assumes strict values between o-100.

Employment outcomes: As a dependent variable, the literature commonly measures changes in employment in terms of growth rates (see for example Ross and Zimmermann (1993); Carree and Thurik (2008); Gebreeyesus (2011); Audretsch et al. (2014); Harrison et al. (2014)). Our key independent variable, product innovation intensity, is measured at the end of 2012. As a result, predicting the impact of product innovation intensity on employment growth that occured between 2012 and 2010 is time-wise inconsistent. We, therefore, use 3 main employment variables namely: permanent employment, temporary employment and total employment. ${ }^{18}$ Permanent employment is defined as the total number of permanent, full-time employees at the end of the last fiscal year, that is, at the end of 2012. Temporary employment is defined as the total number of full-time temporary employees at the end of 2012. Total employment is the addition of permanent employment and temporary employment. All outcome variables are logged in our empirical analysis. The log of temporary employment is generated by adding 1 to the number of temporary employees before taking logs to avoid missing firms that do not have temporary employees. ${ }^{19}$

Various determinants of employment have been identified in both the innovation and labour economics literature. In addition to our innovation variables, we controlled for other key covariates such as cost of labour, total sales and total employment. Total sales and total employment are lagged in order to minimise the problem of reverse causality. Change in market share or change in demand for a firm's product is identified to positively influence changes in employment at the firm-level (Ross and Zimmermann, 1993; Brouwer et al., 1993). Measuring changes in market share as the logarithm of total sales in 2010 (converted to United States Dollars), we expect increases in the market share of firms to have positive impact on total employment. High cost of labour leads to low demand for labour at the firm-level (Ross and Zimmermann, 1993). Following other empirical studies, we introduced the cost of labour, measured as the logarithm of labour cost in United States Dollars in 2012, to capture this. The hypothesis is that the higher the increase in the wage bill of a firm, the higher the decrease in total employment. The empirical literature indicates the role small-sized firms play in creating new jobs (Ross and Zimmermann, 1993; Brouwer et al., 1993).

18 Our analysis focuses only on temporary employment and permanent employment due to measurement problems with other classifications of employment, such as skilled versus unskilled workers and female versus male workers.

19 Although these employment variables do not capture changes, they provide relevant insights that help to better understand firm-level employment. 
We also introduced firm size, measured as the logarithm of total number of employees in 2010, to control for possible endogeneity. The hypothesis is that larger firms at the beginning of the period remain large at the end of the period.

\subsubsection{A Descriptive analysis}

Due to the large number of cross missing values, there were large drops in the number of firms across our regressions. Despite the enormous drop in the number of firms, the representativeness of the population was relatively maintained in terms of sector and size. ${ }^{20}$ Table 2.1 shows the descriptive statistics for our main variables based on 1,158 observations used in our extended regression in Table 2.3 (3). For each variable, we sub-divided the sample into innovators and non-innovators across all countries under consideration. Out of 1,158 observations used, 504 firms representing about $43.5 \%$ of firms introduced product innovations with mean percentage sales from all product innovations (product innovation intensity) of about $35.38 \%$. In terms of total employment, product innovators, on one hand, employ about 74 workers on the average while non-product innovators employ on the average 33 workers. The above descriptive statistics indicate that in our sample, total employment tends to be lower for non-product innovators as compared to product innovators. A closer look across each country descriptive statistics, however, indicates mixed employment outcomes. For example, innovators in Tanzania, on the average, employed lower number of workers as compared to non-product innovators. Our data also show higher permanent employment across all countries for product innovators, with mean of about 63 workers. In terms of temporary employment, product innovators across all countries with the exception of Tanzania, employed higher number of temporary workers in comparison with non-product innovators. Non-innovative firms in Tanzania, however, employed about 28 temporary workers while product innovators employed about 13 temporary workers.

In terms of innovation activities such as patent and license, we observe that majority of product innovators do not undertake these activities. For instance, 123 product innovators responded to have applied for patent over the period under consideration while 381 product innovators responded otherwise. About 67 non-product innovators also responded to have patented over the period. With regards to licensing activity, 46 (26) product innovators (non-product innovators) responded to have purchased an invention over the last 3 fiscal years. These indicate that innovation activities do not always lead to innovations, and innovation activities are not only done by innovators.

20 See Table A.2 in appendix. 
Table 2.1: Descriptive statistics of innovation and employment variables

\begin{tabular}{|c|c|c|c|c|c|c|}
\hline & ALL & DRC & $\mathrm{GH}$ & $\mathrm{TZ}$ & UGA & ZAM \\
\hline No. of firms & 1,158 & 238 & 320 & 107 & 149 & 344 \\
\hline \multicolumn{7}{|l|}{ Product innovation } \\
\hline Innovators & 504 & 92 & 89 & 23 & 95 & 205 \\
\hline Non-innovators & 654 & 146 & 231 & 84 & 54 & 139 \\
\hline Product Intensity (Mean \% sales) & $35 \cdot 38$ & 47.67 & 34.83 & 47.0 & 42.22 & 25.92 \\
\hline \multicolumn{7}{|l|}{ Total employment (Mean) } \\
\hline Product Innovators & 74.23 & 76.25 & $44 \cdot 52$ & 60.35 & 152.34 & 51.59 \\
\hline Non-Product Innovators & 32.80 & 34.21 & $27 \cdot 10$ & 61.23 & 23.96 & $25 \cdot 57$ \\
\hline \multicolumn{7}{|l|}{ Permanent employment (Mean) } \\
\hline Product Innovators & 63.07 & 65.64 & 32.39 & $47 \cdot 74$ & 133.57 & 44.29 \\
\hline Non-Product Innovators & 25.67 & 29.16 & $24 \cdot 47$ & 33.58 & 17.83 & 22.29 \\
\hline \multicolumn{7}{|l|}{ Temporary employment (Mean) } \\
\hline Product Innovators & 11.16 & 10.61 & 12.13 & 12.61 & 18.77 & $7 \cdot 30$ \\
\hline Non-Product Innovators & 7.13 & 5.05 & $3 \cdot 53$ & 27.65 & 6.13 & 3.28 \\
\hline \multicolumn{7}{|l|}{ Patent (No. of respondents) } \\
\hline \multicolumn{7}{|l|}{ Product Innovators } \\
\hline Yes & 123 & 25 & 17 & 9 & 21 & 51 \\
\hline No & 381 & 62 & 72 & 14 & 74 & 154 \\
\hline \multicolumn{7}{|l|}{ Non-Product Innovators } \\
\hline Yes & 67 & 7 & 10 & 23 & 5 & 22 \\
\hline No & 587 & 139 & 221 & 61 & 49 & 117 \\
\hline \multicolumn{7}{|l|}{ License (No. of respondents) } \\
\hline \multicolumn{7}{|l|}{ Product Innovators } \\
\hline Yes & 46 & 13 & 2 & 6 & 13 & 12 \\
\hline No & 458 & 74 & 87 & 17 & 82 & 193 \\
\hline \multicolumn{7}{|l|}{ Non-Product Innovators } \\
\hline Yes & 26 & 1 & 6 & 14 & 2 & 3 \\
\hline No & 628 & 145 & 225 & 70 & 52 & 136 \\
\hline
\end{tabular}

Source: ES and Innovation Follow-up surveys. 


\subsubsection{Estimation results}

Table 2.2 below presents the second stage estimation results showing the impact of product innovations on total employment (log) in 5 countries: Democratic Republic of Congo, Ghana, Tanzania, Uganda and Zambia. We estimated different model specifications where we sequentially added different sets of control variables to extend the basic specification for robustness check. We included in all extended regressions sector and location dummies. It is useful to mention, also, that the estimated coefficient of product innovation is our estimate of the Average Treatment Effect (ATE) as indicated in the estimation equation. In other words, the estimated coefficient of product innovation indicates, ceteris paribus, the average effect of firms' innovative products on total employment.

In all estimations, we considered product innovation intensity and the introduction of product innovations as endogenous. Employing license as instrument for intensity of product innovations and patent as instrument for the introduction of product innovations, our results indicate a significantly positive impact of product innovations on total employment. The stability of this result across all specifications suggests that firms, during the period under consideration, favoured and adopted technological competitive strategies with product quality and market expansion advantages leading to compensation impacts on total employment. This may be due to the rise of the middle class with incessant demand for new products in SSA. This result fits with existing empirical findings by Harrison et al. (2014); Meriküll (2010); Hall et al. (2008); Peters (2008); Piva et al. (2005, 2003). These studies find product innovations to generally have positive job creation effects. Our polynomial terms $\left(T_{1} w, T_{2} w, T_{3} w\right)$ are all strongly significant in the extended model (3). This result justifies our assumption of non-linearity and implies that product innovation intensities impact total employment differently.

Other significant predictors across the extended specification include log of total employment (-2), log of sales (USD,-2), R\&D and log of labour cost (USD). The total employment of the firm, at the beginning of the period, is found to have a positive impact on the total employment of firms across all specifications. Firms that engage in $R \& D$ activities are also found to have high total employment than firms that do otherwise. This suggests that investments in R\&D related activities lead to employment of more workers. In addition, total sales (USD, -2) shows a positive impact on total employment across all specifications, suggesting that firms with larger market share tend to employ more workers. Increase in the cost of labour is also found to discourage firms from hiring workers. 
Table 2.2: Employment impact of firm-level product innovations

\begin{tabular}{|c|c|c|c|}
\hline \multirow[t]{2}{*}{ Estimation method } & \multicolumn{3}{|c|}{ Full-information maximum likelihood (FIML) } \\
\hline & (1) & $(2)$ & (3) \\
\hline & \multicolumn{3}{|c|}{ Total employment(log) } \\
\hline \multirow[t]{2}{*}{ Product innovation $(\mathrm{w})$} & $0.913^{* * *}$ & $0.125^{* * *}$ & $0.203^{* * *}$ \\
\hline & $(15 \cdot 42)$ & $(6.52)$ & $(5.62)$ \\
\hline \multirow[t]{2}{*}{$\mathrm{T}_{1} \mathrm{w}$} & & & $-0.012^{* *}$ \\
\hline & & & $(-2.23)$ \\
\hline \multirow[t]{2}{*}{$\mathrm{T}_{2} \mathrm{~W}$} & & & $0.000^{* *}$ \\
\hline & & & $(2.24)$ \\
\hline \multirow[t]{2}{*}{$\mathrm{T}_{3} \mathrm{~W}$} & & & $-0.000^{* *}$ \\
\hline & & & $(-2.33)$ \\
\hline \multirow[t]{2}{*}{ Log of experience } & & -0.007 & -0.015 \\
\hline & & $(-0.41)$ & $(-0.87)$ \\
\hline \multirow[t]{2}{*}{ Log of total employment $(-2)$} & & $0.716^{* * *}$ & $0.717^{* * *}$ \\
\hline & & $(4.14)$ & $(3 \cdot 32)$ \\
\hline \multirow[t]{2}{*}{ Log of sales (USD) (-2) } & & $0.040^{* * *}$ & $0.037^{* * *}$ \\
\hline & & $(5.88)$ & $(5 \cdot 35)$ \\
\hline \multirow[t]{2}{*}{$R \& D$} & & $0.052^{* * *}$ & $0.043^{*}$ \\
\hline & & $(2.82)$ & $(1.74)$ \\
\hline \multirow[t]{2}{*}{ Log of labour cost (USD) } & & $-0.032^{* * *}$ & $-0.035^{* * *}$ \\
\hline & & $(-3 \cdot 43)$ & $(-3 \cdot 59)$ \\
\hline \multirow[t]{2}{*}{ Age } & & -0.003 & -0.003 \\
\hline & & $(-1.36)$ & $(-1.26)$ \\
\hline \multirow[t]{2}{*}{ Age Square } & & 0.000 & 0.000 \\
\hline & & $(1.61)$ & $(1.51)$ \\
\hline Country fixed effect & No & Yes & Yes \\
\hline $\mathrm{N}$ & 2185 & 1160 & 1158 \\
\hline Wald chi ${ }^{2}$ & 2373.13 & 3932.53 & 9604.02 \\
\hline Prob $>\mathrm{chi}^{2}$ & 0.000 & 0.000 & 0.000 \\
\hline
\end{tabular}

Notes: Robust $\mathrm{t}$ statistics in parentheses, ${ }^{*} p<0.10,{ }^{* *} p<0.05,{ }^{* * *} p<0.01$.

Used cmp Stata package for FIML estimation.

All extended regressions include sector, 23 industry, region and city fixed effects.

All $\mathrm{t}$ statistics are robust to heteroskedasticity.

Instruments: Patent for product innovation; License for product innovation intensity. 


\subsubsection{A Employment responses}

As noted, innovative firms have different product innovation intensities that may have different impacts on employment outcomes. We, therefore, estimated the Dose Response Function (DRF) in this section to analyse the impact of different levels of product innovation intensities on the total employment $(\log )$ of the firm. Based on the regression results in Table 2.2, we determined the average expected conditional total employment $(\log )$ given the product innovation intensity and the other covariates. The DRF derived from the estimation in column 3 of Table 2.2 is plotted in Figure 2.1 below.

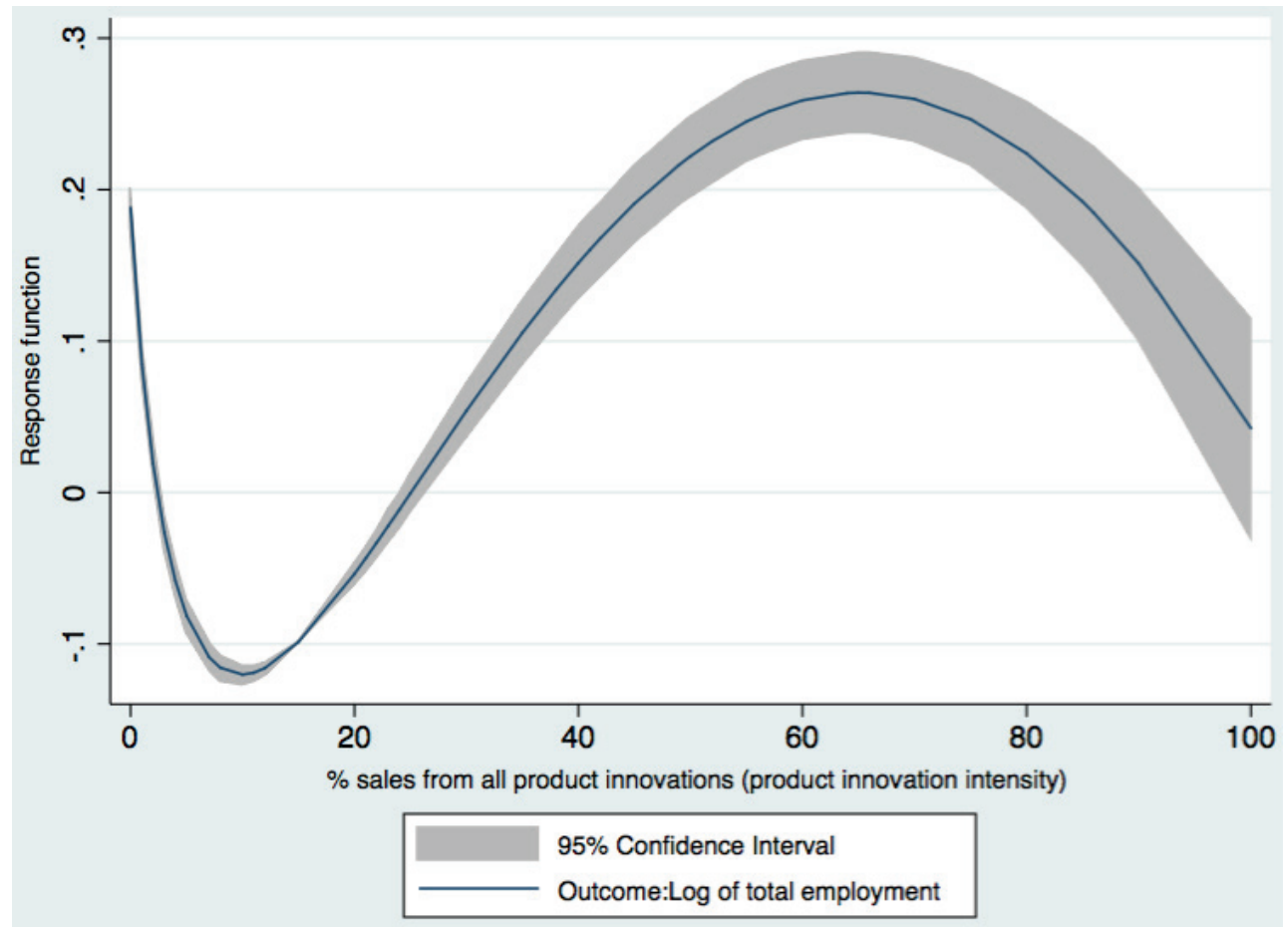

Figure 2.1: Dose Response Function for total employment (log).

Figure 2.1 shows the different total employment (log) responses of firms evaluated across all product innovation intensities. The shape of the relationship implies that, on the average, total employment falls from a positive point, reaches a negative, minimum point then rises to a positive, maximum point and declines thereof as percentage sales from all innovative products increase. The implication of this is that total employment tends to decrease and increase within specific intervals of firms' percentage sales from all product innovations. In other words, the compensation effect seen in Table 2.2 is driven mainly by product innovation intensities between about $11 \%$ to about $63 \%$. This result may be due to uncertainty posed by 'dual' competition in 
the market and the type of product innovations introduced. Firms whose sales from product innovations constitute a large portion of total sales may be first-time and often mono-product innovators. Due to uncertainty in the product market, these firms may be reluctant to employ new workers and may as well lay-off workers with the introduction of product innovations. A major finding by Harrison et al. (2014) and Peters (2008), among many others, is that firm-level employment grows with the growth in sales due to product innovations. Our DRF reveals this conclusion only holds within a sub-interval of percentage sales from all new product innovations.

\subsubsection{Extension to decent employment}

Productive $^{21}$ and decent ${ }^{22}$ employment are widely recognised in the growth-poverty nexus literature as critical mechanisms through which the benefits of growth are distributed (Islam, 2004, 2013; Osmani, 2005; Martins and Takeuchi, 2013; International Labour Office (ILO)., 2012). 'Decent work and economic growth' is the $8^{\text {th }}$ goal of the Sustainable Development Goals (SDGs) adopted in 2015. Achieving decent work for all has been found to be important in achieving other goals such as 'no poverty' (SDG 1), 'zero hunger' (SDG 2) and 'quality education' (SDG 4), through income earned both in the wage sector and self-employed activities (International Labour Office (ILO)., 2012). As a result, there is a renewed policy interest, particularly in developing countries, on how to nurture and generate decent employment. In this light, the role of innovation (SDG 9) is well emphasised in development economics. Using permanent employment versus temporary employment as proxies for job security, we extend our analysis in this section to examine the impact of innovation on decent employment in SSA. According to Harrison et al. (2014), analyses that differentiate types of employment are major contributions to the literature.

Table 2.3 presents both estimates for permanent and temporary employment used as proxies for employment security. Results indicate compensation impact of product innovations on both permanent employment (A-(2)) and temporary employment (B-(4)). Our findings, however, indicate that the compensation impact of product innovation on temporary employment tends to outweigh that of permanent employment. These results are robust and suggest that product innovators prefer to hire more on temporary basis rather than on permanent basis. One explanation for this may be the labour cost differences. Firms that employ temporary workers are not required by law to pay social security and income tax for their temporary employees. For permanent workers, however, firms are required to pay social security for each worker which may

21 The International Labour Office (ILO). (2012, p. 3) defines productive employment as 'employment yielding sufficient returns to labour to permit the worker and her/his dependents a level of consumption above the poverty line.'

22 Decent employment/work in this context, refers to work that is secured. See International Labour Office (ILO). (2013, p. 12) for broader definition. 
lead to higher cost burdens. In order to cut cost, firms may prefer to hire on temporary basis rather than on permanent terms. Another explanation may be due to the risk associated with innovation and the uncertainty about the performance of product innovations. Uncertainty may come from the fact that firms do not absolutely know how their new products would perform in product markets in the short-term and, as a result, may prefer to offer temporary contracts rather than permanent contracts. The results do not change after controlling for skill differences.

Our polynomial terms are also significant for both permanent employment and temporary employment. The implication of their opposite signs is that product innovative firms, on the average, substitute temporary employment for permanent employment at very low and at very high intensities of product innovation while substituting permanent employment for temporary employment at intermediate product innovation intensities. This may be due to the uncertainty associated with the performance of product innovations on the market.

\subsubsection{Additional Robustness}

In order to check the robustness of our results, we assumed $g(t)$ follows a linear form $(g(t)=b t)$ rather than a three degree polynomial, that is, $g(t)=b t+c t^{2}+d t^{3}$. As a result, our estimation equation from (2.71) becomes:

$$
y=a_{0}+x \delta_{0}+w A T E+w[x-\bar{x}] \delta+b w T_{1}+\varepsilon_{y}
$$

Our estimation results showing the impact of product innovations on total employment as well as on the proxies of decent employment assuming a linear form are shown in Tables A.3 and A.4 in the appendix respectively. Results are generally consistent in terms of significance and sign of variables as compared with our earlier results. We, however, found across all specifications that ATE of introducing product innovations reduced in size. Our linear variable $\left(\mathrm{T}_{1} \mathrm{w}\right)$ is also found to be smaller in size. These suggest that our linear models underestimate the impact of product innovations, and also fail to capture appropriately the non-linearity of product innovation intensities. These conclusions also hold when we employed our proxies for decent employment (see appendix A.4: (2) and (4)). 
Table 2.3: Permanent vrs. temporary employment impact of product innovations

\begin{tabular}{|c|c|c|c|c|}
\hline \multirow[t]{3}{*}{ Estimation method } & \multicolumn{4}{|c|}{ Full-information maximum likelihood (FIML) } \\
\hline & \multicolumn{2}{|c|}{ A } & \multicolumn{2}{|c|}{$\mathrm{B}$} \\
\hline & $(1)$ & $(2)$ & (3) & $(4)$ \\
\hline & \multicolumn{2}{|c|}{ Permanent employment } & \multicolumn{2}{|c|}{ Temporary employment } \\
\hline Product innovation (w) & $\begin{array}{l}0.577^{* * *} \\
(2.93)\end{array}$ & $\begin{array}{c}0.052^{* * *} \\
(3.70)\end{array}$ & $\begin{array}{l}0.432^{* * *} \\
(7 \cdot 50)\end{array}$ & $\begin{array}{c}0.398^{* * *} \\
(4.14)\end{array}$ \\
\hline $\mathrm{T}_{1} \mathrm{w}$ & & $\begin{array}{l}-0.274^{* *} \\
(-1.98)\end{array}$ & & $\begin{array}{c}0.040^{* *} \\
(2.16)\end{array}$ \\
\hline $\mathrm{T}_{2} \mathrm{~W}$ & & $\begin{array}{l}0.006^{*} \\
(1.87)\end{array}$ & & $\begin{array}{l}-0.001^{*} \\
(-1.78)\end{array}$ \\
\hline $\mathrm{T}_{3} \mathrm{w}$ & & $\begin{array}{l}-0.000^{*} \\
(-1.79)\end{array}$ & & $\begin{array}{l}0.000^{*} \\
(1.84)\end{array}$ \\
\hline Log of experience & & $\begin{array}{l}0.059 \\
(1.55)\end{array}$ & & $\begin{array}{l}-0.074 \\
(-1.33)\end{array}$ \\
\hline Log of total employment (-2) & & $\begin{array}{l}0.573^{* * *} \\
(13.50)\end{array}$ & & $\begin{array}{l}0.770^{* * *} \\
(11.48)\end{array}$ \\
\hline Log of sales (USD)(-2) & & $\begin{array}{c}0.069^{* * *} \\
(4.48)\end{array}$ & & $\begin{array}{l}0.008 \\
(0.38)\end{array}$ \\
\hline $\mathrm{R} \& \mathrm{D}$ & & $\begin{array}{l}0.000 \\
(0.00)\end{array}$ & & $\begin{array}{l}0.145^{*} \\
(1.77)\end{array}$ \\
\hline Log of labour cost (USD) & & $\begin{array}{l}-0.037^{* *} \\
(-2.14)\end{array}$ & & $\begin{array}{l}-0.029 \\
(-1.01)\end{array}$ \\
\hline Age & & $\begin{array}{l}-0.008 \\
(-1.61)\end{array}$ & & $\begin{array}{l}-0.008 \\
(-1.26)\end{array}$ \\
\hline Age Square & & $\begin{array}{l}0.000 \\
(1.62)\end{array}$ & & $\begin{array}{l}0.000 \\
(0.85)\end{array}$ \\
\hline Country fixed effect & No & Yes & No & Yes \\
\hline $\mathrm{N}$ & 1158 & 1158 & 1158 & 1158 \\
\hline Wald chi ${ }^{2}$ & 2714.184 & 6072.68 & 6665.763 & 8802.2426 \\
\hline Prob $>\mathrm{chi}^{2}$ & 0.000 & 0.000 & 0.000 & 0.000 \\
\hline
\end{tabular}

Notes: Robust $\mathrm{t}$ statistics in parentheses, ${ }^{*} p<0.10,{ }^{* *} p<0.05,{ }^{* * *} p<0.01$.

Used cmp Stata package for FIML estimation.

All extended regressions include sector, 23 industry, region and city fixed effects.

All $\mathrm{t}$ statistics are robust to heteroskedasticity.

Instruments: Patent for product innovation; License for product innovation intensity. 


\subsection{CONCLUSION}

The relationship between innovation and employment remains central especially in sub-Saharan African (SSA) economies, where 'innovation-led' development thinking is emerging. In this chapter, we sought to contribute to the deeper understanding of the causal relationship between product innovation and employment in SSA, by employing a counterfactual stance where we considered varying innovation intensities.

The chapter adapted the Dose Response Model under continuous treatment and used the World Bank's Enterprise Survey (ES) merged with the Innovation Follow-Up Survey data for 5 sub-Saharan African countries, namely Congo Democratic Republic, Ghana, Tanzania, Uganda and Zambia. Our results highlight the critical importance of product innovation activities in stimulating total employment of firms in SSA. We have shown that this conclusion only holds within specific sub-interval of firms' intensities of innovation. In other words, the impact of firms' innovation activities on total employment varies and depends on the market performance of 'new or significantly improved' goods and services. In extensions to decent employment, we employed proxies for security of job and our results suggest product innovation leads to the creation of both permanent and temporary jobs. Our results, however, indicate that product innovation tends to create more temporary jobs than permanent jobs as firms trade between permanent and temporary jobs at different intensities of product innovation.

The policy implications of these results cannot be overemphasised. In a continent where policy is being directed towards enhancing innovations at the firm-level, our results reveal that policy makers need to be wary if the primary motive of the innovation policies is to generate decent employment in the short-term. This is because, the intensity of product innovations is not homogeneous but heterogeneous across firms with different compensating and displacement impacts on employment. We, therefore, suggest policy efforts that promote product innovations but also offer some form of security to all types of workers, be it temporary or permanent. 


\section{REFERENCES}

Amemiya, T. (1973). Regression Analysis when the Dependent Variable Is Truncated Normal. Econometrica, 41(6):997-1016.

Amemiya, T. (1985). Advanced Econometrics. Harvard University Press, 1 edition.

AU-NEPAD. (2010). African Innovation Outlook 2010. Technical report, African Union-New Partnership for Africa's Development, Pretoria, South Africa.

AU-NEPAD. (2014). African innovation outlook II. Technical report, African UnionNew Partnership for Africa's Development, Pretoria, South Africa.

Audretsch, D. B., Coad, A., and Segarra, A. (2014). Firm growth and innovation. Small Business Economics, 43(4):743-749.

Baum, C. F. and Cerulli, G. (2016). Estimating a dose-response function with heterogeneous response to confounders when treatment is continuous and endogenous. Paper number 9388 presented in EcoMod2016 conference, Lisbon, Portugal.

Bogliacino, F. and Pianta, M. (2010). Innovation and Employment: A Reinvestigation using Revised Pavitt classes. Research Policy, 39(6):799-809.

Brouwer, E., Kleinknecht, A., and Reijnen, J. O. N. (1993). Employment growth and innovation at the firm level. Journal of Evolutionary Economics, 3(2):153-159.

Calvino, F. and Virgillito, M. E. (2018). The innovation-employment nexus: A critical survey of theory and empirics. Journal of Economic Surveys, 32(1):83-117.

Carree, M. A. and Thurik, A. R. (2008). The lag structure of the impact of business ownership on economic performance in OECD countries. Small Business Economics, 30(1):101-110.

Cerulli, G. (2012). A continuous treatment model for estimating a Dose Response Function under endogeneity and heterogeneous response to observable confounders: Description and implementation via the Stata module "ctreatreg". Working Paper Cnr-Ceris, Number 18.

Cerulli, G. (2014). CTREATREG: Stata module for estimating dose-response models under exogenous and endogenous treatment. Working Paper Cnr-Ceris, Number 05. Retrieved from https://ideas.repec.org/c/boc/bocode/s45782o.html.

Cerulli, G. (2015). ctreatreg: Command for fitting dose-response models under exogenous and endogenous treatment. Stata Journal, 15(4):1019-1045. 
Cerulli, G. and Poti, B. (2014). The Impact of Public Support Intensity on Business R\&D: Evidence from a Dose-Response Approach. 54th Congress of European Regional Science Association 28 August -29 August, St. Petersburg, Russia. Retrieved from https: / /ideas.repec.org/p/wiw/wiwrsa/ersa14.

Classen, N., Carree, M., van Gils, A., and Peters, B. (2014). Innovation in family and non-family SMEs: An exploratory analysis. Small Business Economics, 42(3):595-6o9.

Crespi, G. and Tacsir, E. (2013). Effects of innovation on employment in Latin America. UNU-MERIT Working Papers, Number o01. Retrieved from https://ideas.repec.org/p/unm/unumer/2013001.html.

de Elejalde, R., Giuliodori, D., and Stucchi, R. (2015). Employment and Innovation: Firm-Level Evidence from Argentina. Emerging Markets Finance and Trade, 51(1):2747.

Dosi, G., Freeman, C., Nelson, R., Silverberg, G., and Soete, L., editors (1988). Technical Change and Economic Theory. Pinter, London.

Fagerberg, J., Mowery, D. C., and Nelson, R. R., editors (2005). The Oxford Handbook of Innovation. Oxford University Press.

Fryges, H. and Wagner, J. (2008). Exports and Productivity Growth: First Evidence from a Continuous Treatment Approach. Review of World Economics, 144(4):695-722.

Gallouj, F. and Djellal, F. (2010). The handbook of innovation and services : a multidisciplinary perspective. Edward Elgar, Cheltenham, UK.

Gault, F. (2010). Innovation strategies for a global economy: Development, Implementation, Measurement, and Management. Edward Elgar Publishing, IDRC.

Gebreeyesus, M. (2011). Innovation and Microenterprise Growth in Ethiopia. In Szirmai, A., Naudé, W., and Goedhuys, M., editors, Entrepreneurship, Innovation, and Economic Development, pages 122-146. Oxford University Press.

Hall, B. H., Lotti, F., and Mairesse, J. (2008). Employment, innovation, and productivity: Evidence from Italian microdata. Industrial and Corporate Change, 17(4):813-839.

Harrison, R., Jaumandreu, J., Mairesse, J., and Peters, B. (2014). Does innovation stimulate employment? A firm-level analysis using comparable micro-data from four European countries. International Journal of Industrial Organization, 35(1):29-43.

Imbens, G. and Hirano, K. (2004). The Propensity Score with Continuous Treatments. In Gelman, A. and Meng, X.-L., editors, Applied Bayesian Modeling and Causal Inference from Incomplete-Data Perspectives:An Essential Journey with Donald Rubin's Statistical Family. John Wiley \& Sons, Ltd, Chichester, UK. 
International Labour Office (ILO). (2012). Understanding deficits of productive employment and setting targets: A methodological guide. Technical report, ILO, Geneva.

International Labour Office (ILO). (2013). Youth unemployment rate estimates and projections by region 2007-2017. Technical report, International Labour Office, Geneva.

Islam, R. (2004). The Nexus of Economic Growth, Employment and Poverty Reduction: An Empirical Analysis. Issues in Employment and Poverty Discussion Paper, Number 14. Retrieved from http://ilo.int/wcmsp5/groups/public/ed_emp/documents/publication/wcms_120690.pdf.

Islam, R. (2013). Integrating Productive Employment into the Post-2015 Development Agenda. Southern Voice Occasional Paper, 3.

Konte, A. and Ndong, M. (2012). The informal ICT sector and innovation processes in Senegal. African Journal of Science, Technology, Innovation and Development, 4(3):61-97.

Lachenmaier, S. and Rottmann, H. (2011). Effects of innovation on employment: A dynamic panel analysis. International Journal of Industrial Organization, 29(2):210220.

Mairesse, J. and Mohnen, P. (2010). Using innovation surveys for econometric analysis. In Hall, B. H. and Rosenberg, N., editors, Handbook of the Economics of Innovation, volume 2, chapter 26, pages 1129-1155. North-Holland.

Martins, P. and Takeuchi, L. R. (2013). Employment in a post-2015 framework: Proposals for monitoring indicators. Overseas Development Institute Working Paper. Retrieved from https://www.odi.org/sites/odi.org.uk/files/odi-assets/publicationsopinion-files /8503.pdf.

Meriküll, J. (2010). The Impact of Innovation on Employment. Eastern European Economics, 48(2):25-38.

Mohnen, P. and Hall, B. H. (2013). Innovation and Productivity: An Update. Eurasian Business Review, 3(1):47-65.

OECD and Eurostat (2005). Oslo Manual. Guidelines for collecting and interpreting innovation data. Organisation for Economic Co-operation and Development, Paris, 3rd edition.

Osmani, S. R. (2005). The Role of Employment in Promoting the Millennium Development Goals. Issues in Employment and Poverty Discussion Paper Number 18. Retrieved from http://www.ilo.org/wcmsp5/groups/public/ed_emp/documents/publication/wcms_120685.pdf. 
Peters, B. (2005). Employment Effects of Different Innovation Activities: Microeconometric Evidence. ZEW - Zentrum f\{ü\}r Europ\{ä\}ische Wirtschaftsforschung / Center for European Economic Research Working Paper Number 04-73. Retrieved from https://ideas.repec.org/p/zbw/zewdi.

Peters, B. (2008). Innovation and Firm Performance: An Empirical Investigation for German Firms. Physica-Verlag, Heidelberg New York, 38 edition.

Pianta, M. (2005). Innovation and Employment. In Fagerberg, J., Mowery, D., and Nelson, R., editors, The Oxford Handbook of Innovation. Oxford University Press, Oxford.

Pianta, M. and Antonucci, T. (2002). Employment effects of product and process innovations in Europe. International Review of Applied Economics, 16(3).

Piva, M., Santarelli, E., and Vivarelli, M. (2003). The Skill Bias Effect of Technological and Organisational Change: Evidence and Policy Implications. Institute for the Study of Labor (IZA) Discussion Paper No. 934 Bonn, Germany.

Piva, M., Santarelli, E., and Vivarelli, M. (2005). The skill bias effect of technological and organisational change: Evidence and policy implications. Research Policy, 34(2):141-157.

Ross, D. R. and Zimmermann, K. F. (1993). Evaluating reported determinants of labor demand. Labour Economics, 1(1):71-84.

Schumpeter, J. A. (1934). The theory of economic development : An inquiry into profits, capital, credit, interest, and the business cycle. Harvard University Press, Cambridge, Massachusets.

van Dijk, M. P. and Sandee, H. (2002). Innovation and Small Enterprise Development in Developing Countries: Some Conclusions. Edward Elgar Publishing, Inc., Cheltenham, UK.

Verspagen, B. (1992). Endogenous innovation in neoclassical growth models: A survey. Journal of Macroeconomics, 14(4):631-662.

Verspagen, B. (2004). Innovation and Jobs: a Micro-and-Macro Perspective. Eindhoven Centre for Innovation Studies Working Paper Number 04-15. Retrieved from https: / / pure.tue.nl/ws/files/2089240/585735.pdf.

Vivarelli, M. (2014). Innovation, Employment and Skills in Advanced and Developing Countries: A Survey of Economic Literature. Journal of Economic Issues, 48(1):123154.

Wooldridge, J. M. (2013). Introductory econometrics: a modern approach. South-Western Cengage Learning, Mason, $\mathrm{OH}$. 


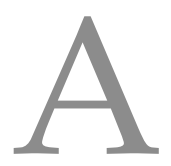

APPENDIX

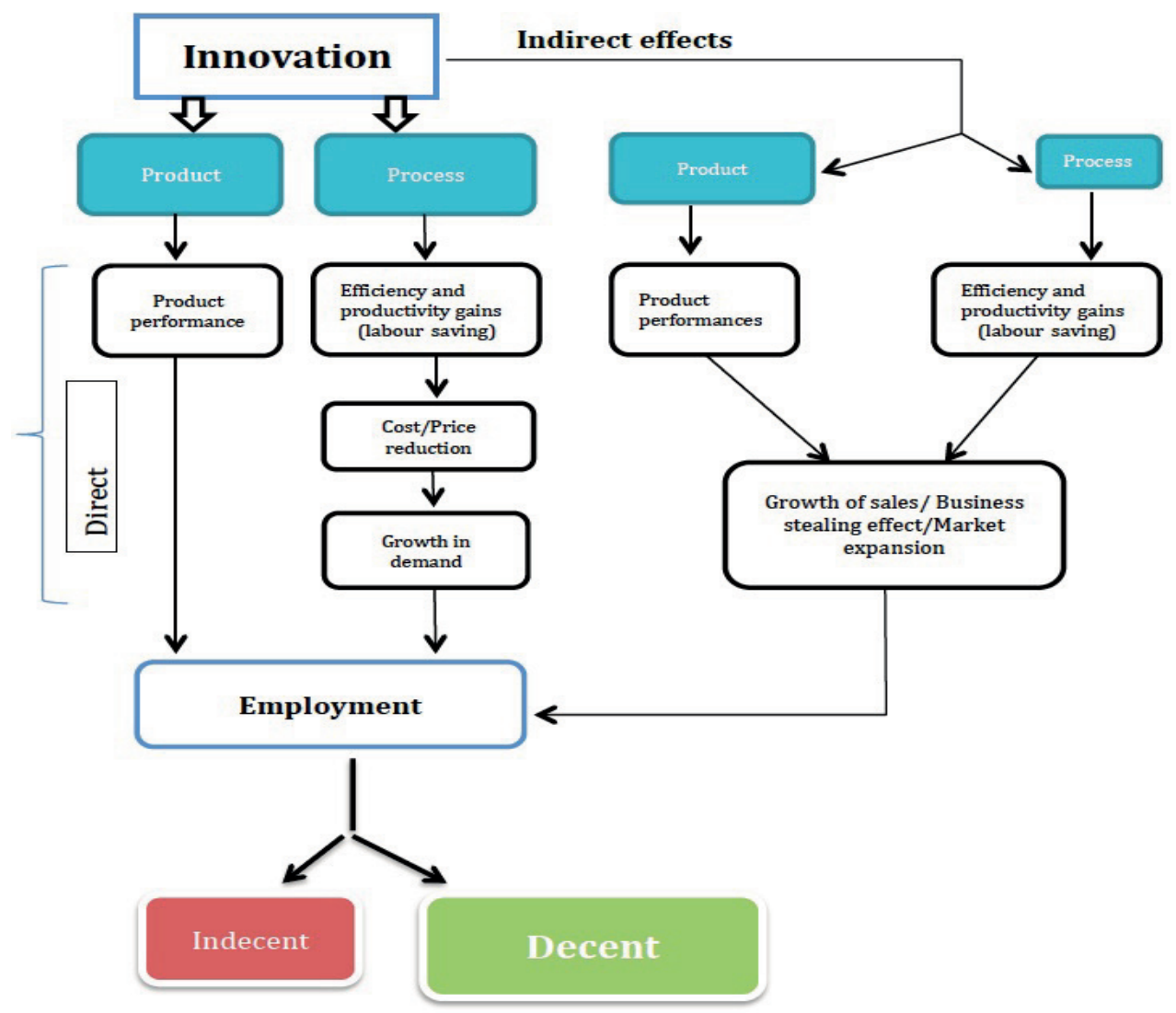

Figure A.1: Simple theoretical relationship between product and process innovations and employment at the firm-level

Sources: Adapted from Evangelista \&Vezzani (2010) and Gallouj \& Djellal (2010) 


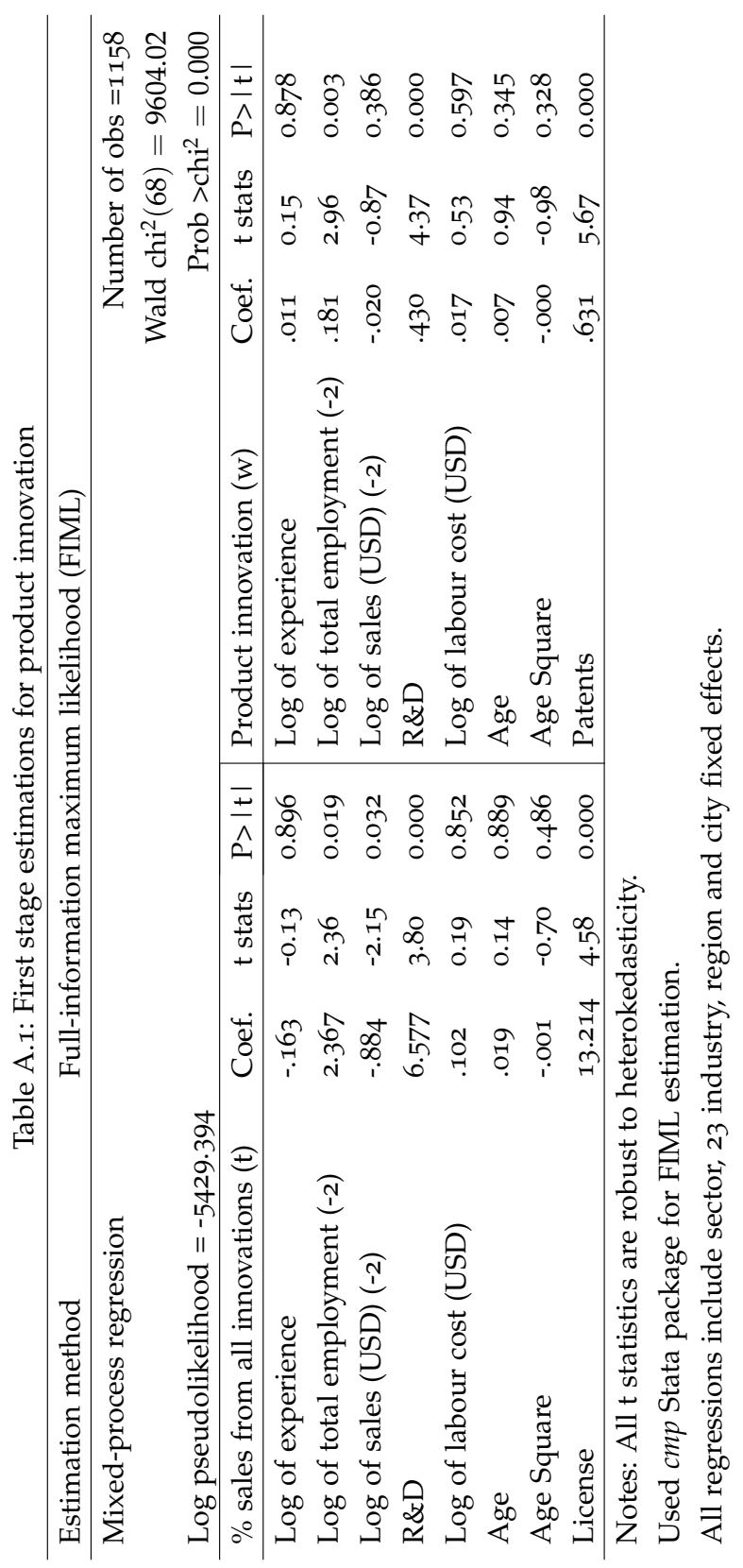




\section{A.2: DEFINITION OF VARIABLES}

Total employment(log): the logarithm of the addition of permanent employment and temporary employment.

Permanent employment(log): the logarithm of total number of permanent, fulltime employees at the end of the last fiscal year.

Temporary employment(log): the logarithm of total number of full-time temporary employees at the end of the last fiscal year. Temporary employment $(\log )$ is constructed by adding 1 to the number of temporary employees before taking logs to avoid missing firms that do not have temporary employees.

Product innovation: a binary variable taking the value of 1 if the firm has introduced at least one product innovation over the last 3 fiscal years and o if otherwise.

Product innovation intensity: a continuous variable indicating the percentage of total sales represented by sales from all innovative products or services at the end of the last fiscal year. It assumes strict values between o-100. Zero implies the firm has not introduced product innovation.

Log of experience: the logarithm of the number of working years of the top manager at the end of the last fiscal year.

Log of total employment (-2): the logarithm of total number of employees at the end of 3 fiscal years ago.

Log of sales (USD) (-2): the logarithm of total sales in last 3 fiscal years converted to United States Dollars using exchange rate in corresponding fiscal year.

R\&D: a binary variable taking the value of 1 if the firm has spent on formal R\&D activities during the last three years and o if otherwise.

Log of labour cost (USD): the logarithm of labour cost in United States Dollars in the last fiscal year. This is constructed as total cost of labour converted using exchange rate in the last fiscal year.

License: a dummy variable that takes value 1 if the firm purchased any patented or non-patented inventions over the last 3 fiscal years and o if otherwise.

Patent: a dummy variable that takes value 1 if the firm applied for a patent concerning a product innovation or concerning process innovation or both over the last 3 fiscal years and o if otherwise.

Age: the number of years the firm has being operating at the end of the last fiscal year.

Age square: the square of the number of years the firm has being operating at the end of the last fiscal year.

Size of firm: A categorical variable that takes value o if the firm is micro $(<5), 1$ if the firm small $(\geq 5$ and $\leq 19), 2$ if the firm is medium $(\geq 20$ and $\leq 99)$ and 3 if large (100 and over).

Industry: sectors according to the group classification of ISIC Revision 3.1: group D, construction sector (group F), services sector (groups G and H), and transport, storage communications sector (group I) and IT (group K sub-sector 72). 
Sector: a categorical variable that takes value o if the firm is engaged in manufacturing, 1 if firm is engaged in retail and 2 if firm is engaged in other services.

Region: a categorical variable that indicates the region a firm is located.

City: a dummy variable that takes value 1 if the firm is located in the main city of business and o if otherwise. 
Table A.2: Population and sample representation of data

\begin{tabular}{lcc}
\hline & Population & Sample \\
\hline No. of firms & 2,466 & 1,158 \\
Country & & \\
$\quad$ Congo, DR (\%) & 15.61 & 20.55 \\
Ghana (\%) & 22.26 & 27.63 \\
Tanzania (\%) & 22.02 & 9.24 \\
Uganda (\%) & 18.21 & 12.87 \\
Zambia (\%) & 21.90 & 29.71 \\
Sector & & \\
Manufacturing (\%) & 49.31 & 52.16 \\
$\quad$ Retail (\%) & 19.79 & 17.44 \\
$\quad$ Other services (\%) & 30.90 & 30.40 \\
Size of firm & & \\
Small (\%) & 65.73 & 64.68 \\
Medium (\%) & 26.89 & 28.07 \\
Large (\%) & 7.38 & 7.25 \\
\hline
\end{tabular}

Source: ES and Innovation Follow-up surveys.

Note: The sample data is based on the extended regression in Table 2.3 (3). 
Table A.3: Employment impact of firm-level product innovations

\begin{tabular}{|c|c|c|}
\hline \multirow[t]{2}{*}{ Estimation method } & \multicolumn{2}{|c|}{ Full-information maximum likelihood (FIML) } \\
\hline & $(1)$ & $(2)$ \\
\hline & \multicolumn{2}{|c|}{ Total employment(log) } \\
\hline \multirow[t]{2}{*}{ Product innovation (w) } & $0.085^{* * *}$ & $0.109^{* * *}$ \\
\hline & $(3 \cdot 34)$ & $(4.27)$ \\
\hline \multirow[t]{2}{*}{$\mathrm{T}_{1} \mathrm{w}$} & $-0.002^{* * *}$ & $-0.001^{*}$ \\
\hline & $(-2.61)$ & $(-1.85)$ \\
\hline \multirow[t]{2}{*}{ Log of experience } & -0.004 & -0.008 \\
\hline & $(-0.24)$ & $(-0.43)$ \\
\hline \multirow[t]{2}{*}{ Log of total employment (-2) } & $0.723^{* * *}$ & $0.721^{* * *}$ \\
\hline & $(20.49)$ & $(20.83)$ \\
\hline \multirow[t]{2}{*}{ Log of sales (USD)(-2) } & $0.034^{* * *}$ & $0.038^{* * *}$ \\
\hline & $(4.99)$ & $(5 \cdot 43)$ \\
\hline \multirow[t]{2}{*}{$R \& D$} & $0.052^{* *}$ & $0.050^{* *}$ \\
\hline & $(2.08)$ & $(2.03)$ \\
\hline \multirow[t]{2}{*}{ Log of labour cost (USD) } & $-0.028^{* * *}$ & $-0.031^{* * *}$ \\
\hline & $(-3.89)$ & $(-3.23)$ \\
\hline \multirow[t]{2}{*}{ Age } & -0.002 & -0.003 \\
\hline & $(-1.24)$ & $(-1 \cdot 30)$ \\
\hline \multirow[t]{2}{*}{ Age Square } & 0.000 & 0.000 \\
\hline & $(1.52)$ & $(1.60)$ \\
\hline Country fixed effect & No & Yes \\
\hline $\mathrm{N}$ & 1158 & 1158 \\
\hline Wald chi ${ }^{2}$ & 9978.32 & 9071.42 \\
\hline Prob $>\mathrm{chi}^{2}$ & 0.000 & 0.000 \\
\hline
\end{tabular}

Notes: Robust $\mathrm{t}$ statistics in parentheses, ${ }^{*} p<0.10,{ }^{* *} p<0.05,{ }^{* * *} p<0.01$.

Used cmp Stata package for FIML estimation.

All extended regressions include sector, 23 industry, region and city fixed effects.

All $\mathrm{t}$ statistics are robust to heteroskedasticity.

Instruments: Patent for product innovation; License for product innovation intensity. 
Table A.4: Permanent vrs. temporary employment impacts of product innovation

\begin{tabular}{|c|c|c|c|c|}
\hline \multirow[t]{2}{*}{ Estimation method } & \multicolumn{4}{|c|}{ Full-information maximum likelihood (FIML) } \\
\hline & $(1)$ & $(2)$ & (3) & $(4)$ \\
\hline & \multicolumn{2}{|c|}{ Permanent employment } & \multicolumn{2}{|c|}{ Temporary employmen } \\
\hline \multirow[t]{2}{*}{ Product innovation $(w)$} & 0.019 & $0.048^{*}$ & 0.092 & $0.285^{* * *}$ \\
\hline & $(0.56)$ & $(1.92)$ & $(1.12)$ & $(3 \cdot 51)$ \\
\hline \multirow[t]{2}{*}{$\mathrm{T}_{1} \mathrm{w}$} & $-0.005^{* * *}$ & $-0.003^{* * *}$ & $0.009^{* * *}$ & $0.003^{*}$ \\
\hline & $(-3.82)$ & $(-2.71)$ & $(4 \cdot 53)$ & $(1.70)$ \\
\hline \multirow[t]{2}{*}{ Log of experience } & 0.009 & 0.012 & -0.080 & -0.066 \\
\hline & $(0.35)$ & $(0.46)$ & $(-1.46)$ & $(-1.18)$ \\
\hline \multirow[t]{2}{*}{ Log of total employment $(-2)$} & $0.589^{* * *}$ & $0.573^{* * *}$ & $0.781^{* * *}$ & $0.760^{* * *}$ \\
\hline & $(14 \cdot 50)$ & $(13.44)$ & $(11.55)$ & $(11.28)$ \\
\hline \multirow[t]{2}{*}{ Log of sales (USD)(-2) } & $0.036^{* * *}$ & $0.044^{* * *}$ & 0.007 & 0.014 \\
\hline & $(3.90)$ & $(4 \cdot 70)$ & $(0.32)$ & $(0.66)$ \\
\hline \multirow[t]{2}{*}{$R \& D$} & 0.033 & 0.020 & 0.124 & $0.158^{*}$ \\
\hline & $(0.94)$ & $(0.59)$ & $(1.51)$ & (1.94) \\
\hline \multirow[t]{2}{*}{ Log of labour cost (USD) } & -0.014 & $-0.027^{* *}$ & $-0.053^{* *}$ & -0.033 \\
\hline & $(-1.53)$ & $(-2.43)$ & $(-2.46)$ & $(-1.14)$ \\
\hline \multirow[t]{2}{*}{ Age } & -0.002 & 0.000 & -0.005 & -0.009 \\
\hline & $(-0.66)$ & $(0.05)$ & $(-0.75)$ & $(-1.31)$ \\
\hline \multirow[t]{2}{*}{ Age Square } & 0.000 & -0.000 & 0.000 & 0.000 \\
\hline & $(1.27)$ & $(-0.72)$ & $(0.32)$ & $(0.82)$ \\
\hline Country fixed effect & No & Yes & No & Yes \\
\hline $\mathrm{N}$ & 1158 & 1158 & 1158 & 1158 \\
\hline Wald $\mathrm{chi}^{2}$ & 4687.83 & 6801.03 & 553.41 & 2156.80 \\
\hline Prob $>\mathrm{chi}^{2}$ & 0.000 & 0.000 & 0.000 & 0.000 \\
\hline
\end{tabular}

Notes: Robust $\mathrm{t}$ statistics in parentheses, ${ }^{*} p<0.10,{ }^{* *} p<0.05,{ }^{* * *} p<0.01$.

Used cmp Stata package for FIML estimation.

All extended regressions include sector, 23 industry, region and city fixed effects.

All $\mathrm{t}$ statistics are robust to heteroskedasticity.

Instruments: Patent for product innovation; License for product innovation intensity. 


\subsection{INTRODUCTION}

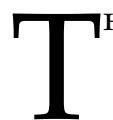
HE informal economy has defied the expectations of traditional development literature by not only persisting over time, but have also grown and expanded over the years. The growing evidence of the 'permanent' feature of informality in developing countries has led to increasing academic and policy interests, in recent years. Typically, development literature considers informality and the activities of informal enterprises as largely negative on the economy. Evidence from firm-level data from developing countries also reveals the market competitive behaviour of informal enterprises as one of the top three obstacles formal businesses face in product markets (see Mendi and Costamagna, 2017; Friesen and Wacker, 2013; Gonzalez and Lamanna, 2007). Despite the growing literature on informality, the economic implications of informal enterprise activities remain under researched (Mendi and Costamagna, 2017; Friesen and Wacker, 2013; Bruton et al., 2012), with very scant empirical studies investigating the effect of informal product market competition (hereafter informal competition) on the innovation strategies of formal firms. This chapter fills this gap by examining the effect of informal competition on the performance of product innovations in sub-Saharan Africa (SSA). ${ }^{1}$

In developing countries, the informal economy is increasingly being seen as a critical socio-economic pillar (Gërxhani, 2004) and a source of livelihood (La Porta and Shleifer, 2008), with highly heterogeneous enterprises (Bargain and Kwenda, 2011). The informal economy is most prevalent in SSA (Schneider et al., 2010), where it dominates economic activities both in terms of output and employment (Heintz and Pollin, 2008). For instance, the sector constitutes 80 percent of the labour force and accounts for nearly 55 percent of GDP for many SSA countries (International Labour Office (ILO)., 2013; African Development Bank, 2013). In Ghana, for example, employment

1 A growing related literature is the informal competition and formal firms' productivity literature (see La Porta and Shleifer, 2008; Ali and Najaman, 2015). 
is found to be predominantly informal employing $86.1 \%$ of the working force (Ghana Statistical Service, 2012) with the production structure made up of Small-Medium Enterprises (SMEs). Informal SMEs are also found to be strong drivers of economic transformation (Haug, 2014).

In addition to serving as a source of livelihood in many developing countries, informal enterprises also pose as a source of informal competition (Mendi and Costamagna, 2017; Gonzalez and Lamanna, 2007) through prices at the 'local-level' where competitive interaction is found to occur in product markets (Ali and Najman, 2015; Gonzalez and Lamanna, 2007). While market competition between firms is recognised widely as the driver of efficiency and growth, empirical evidence and firm-level data from developing countries (mostly from the World Bank Enterprise Surveys) often cite competitive behaviour of informal enterprises as 'unhealthy' and as one of the top three obstacles to formal firms. The characterisation of informal competition as 'unhealthy' may be, as noted by Mendi and Costamagna (2017), a result of the wide market acceptance of informal enterprises in local markets, particularly markets serving those in the bottom of the pyramid.

In the face of informal competition, formal firms may employ vertical product differentiation in order to stay competitive. In other words, formal firms may introduce product innovations. According to van Dijk and Sandee (2002), Gault (2010) and OECD and Eurostat (2005), innovations, particularly product innovations, remain a primary driver of firm technological competitiveness (market performance) through improvements in product quality, offering of new products or opening up new markets or groups of customers, thereby increasing the firm's market share. However, imitation and the increasing complementary interaction between formal and informal businesses, coupled with the dynamic behaviours of informal enterprises may be blurring vertical product differences, particularly in the service sector. Consequently, the competitive advantage formal firms enjoy with vertical product differentiation may be fuzzy in the face of informal competition.

The relationship between innovation and competition in SSA is of particular interest as a result of the growing size of the informal economy as well as the peculiar nature of competition presented by the dualistic economic structure. This chapter, therefore, investigates the effect of informal market competition on the performance of innovative products of registered firms in SSA, and to provide a better understanding of the mechanisms through which these occur.

This chapter contributes to the literature in several ways. The chapter provides, to our knowledge, the first empirical evidence assessing the effect of informal competition on the sales of innovative products. ${ }^{2}$ The chapter departs from the mainstream literature by analysing informal competition, and from similar studies by going beyond the analysis of formal firms' incentives to innovate. What may be relevant for

2 A recent contribution by Mendi and Costamagna (2017) focuses on the implications of informal competition on the incentives of formal firms to introduce product and/or process innovations. This chapter, however, departs by relating the degree of product innovative sales to informal competition. 
firms is not whether to introduce product innovation or otherwise, but how the innovative products perform on the market in the face of dual competition. Analysing the effect of informal competition on product innovation using a binary dependent variable (whether the firm introduces product innovation or not) only determines the incentives to innovate or otherwise. This chapter, therefore, goes beyond establishing a relationship between informal competition and the probability of the firm to introduce product innovation to assessing the effect of informal competition intensity on the performance of product innovation in SSA.

This chapter also contributes to the literature by resolving possible econometric issues of bi-directional causality and the use of subjective responses that may bias our estimates. Using already existing econometric procedures developed by Guiso et al. (2004), Ali and Najman (2015) found informal competition varies across regions within the same country. We follow Guiso et al. (2004) and Ali and Najman (2015) to construct an innovative regional competitive intensity measure that 'localises' competition thereby reducing the possible bi-directional causality between informal competition and sales of innovative products as well as controlling for possible bias due to the subjective nature of the data. We also employed the same procedure to construct industry-level informal competition indicator across industries in each country. These approaches allow us to control and introduce non-linear effects into our model that could help explain, more rigorously, the relationship between informal competition and formal firms' technological innovativeness (see Ali and Najaman, 2015; Aghion et al., 2005; Scherer, 1967). This chapter also follows available econometric methods to control for selection bias associated with innovation where we allow the error terms of both equations to be freely correlated.

In addition, this chapter contributes to the literature by employing data from the Innovation Follow-up Survey (IFS) pooled with the Enterprise Surveys (ES) from the World Bank. While similar studies also employ the ES (see Mendi and Costamagna, 2017; Ali and Najman, 2015; Friesen and Wacker, 2013; Gonzalez and Lamanna, 2007), this chapter departs by pooling data from both ES and the IFS, thereby exploiting a larger number of variables in order to uniquely introduce controls that are uncommon in the literature.

Using data for 5 SSA countries, namely Democratic Republic of Congo (DRC), Ghana (GH), Tanzania (TZ), Uganda (UGA) and Zambia (ZAM), and employing two econometric approaches that localise informal competition in the product market at the first-level of estimation, and controls for self-selection and sample selection biases at the second level of estimation, we have shown that 'local' informal competition matters for the performance of product innovations. Specifically, our results indicate the presence of 'Schumpeterian effect' where informal competition is found to be detrimental to the performance of product innovations. Our conclusion is also found to be valid when we decompose formal firms into sectors, ownership type and size. However, extension to industry-level informal competition indicates an 'escapecompetition effect' of informal competitive activities on the performance of product 
innovation. Our results also show through indirect mechanism that firms with larger market share tend to have 'escape-competition effect'.

The rest of the chapter is organised as follows. Section 3.2 presents the review of relevant literature on the relationship between innovation and product market competition. In Section 3.3, the model and sources of data are presented. Section 3.4 presents the results from the empirical estimation in line with the objectives of the chapter, the discussion of the results as well as the appropriate robustness checks to validate our results. Section 3.5 presents the conclusion of the chapter.

\subsection{RELATED Literature}

The economic development literature establishing firm-level relationship between competition and innovation is relatively developed but remains central in both academic and policy spheres (Blundell et al., 1999; Peroni and Ferreira, 2011) as empirical evidence remain inconclusive (Aghion et al., 2005) and 'subtle' (Aghion et al., 2013). This section situates our chapter into this broad strand of literature. ${ }^{3}$

The literature mainly follows from the seminal contribution by Schumpeter (1942), with theoretical formalisation by Aghion and Howitt (1992). The 'Schumpeterian perspective' of the literature essentially considers vertical innovations as 'creative destructions' of the product market and the source of long-run growth. Competition is considered a bane on innovations as it is considered to destroy the underlying incentives of firms to undertake innovation activities through the prospects of lower rents (Schumpeter, 1942; Aghion and Howitt, 1992; Aghion et al., 2001; Hashmi, 2013). This is referred to as the 'Schumpeterian effect'. Using panel data from the United States of America (USA) and the United Kingdom (UK) and one minus the average Lerner index of firms' industry, citation-weighted patents for competition and innovation respectively, Hashmi (2013) found evidence of a 'Schumpeterian effect' in USA industries.

Contrary to the Schumpeterian perspective is the 'escape-competition effect', where increases in competition serve as an incentive to escape market rivalry by stimulating innovation activities and innovations particularly in industries with low technological gap (see Blundell et al., 1999; Aghion et al., 2001). For instance, Blundell et al. (1999) studied the 'market share, market value and innovation in a panel of British manufacturing firms' by using innovation counts. The authors found 'escape-competition effect' where 'increased product market competition in the industry tended to stimulate innovative activity' with innovative, large market share firms enjoying higher gains on the stock market. Boldrin and Levine (2008) developed a competitive model of innovation where the authors examined post-innovation rents under perfect com-

3 See Gilbert (2006) for a recent survey of the literature. 
petition. Presenting both 'theoretical and practical' situations, the authors also found positive effects of competition on innovation.

A growing part of the literature also identifies a non-linear relationship in the form of an inverted-U, where lower and higher levels of product market competition influence firm-level innovations differently. Lower levels of market competition are found to promote innovation while higher levels of competition inhibit innovation. In other words, this strand finds both the 'Schumpeterian effect' and the 'escape- competition effect' (see Mendi and Costamagna, 2017; Aghion, et al., 2005; Scherer, 1967). An earlier study by Scherer (1967) analysed the effect of market concentration on innovative efforts using data for 56 industries in the USA. Measuring innovative efforts as employment of scientists and technical engineers and market concentration as industry average concentration ratios weighted by shipment values, the author found that lower industry concentrations tend to promote innovative efforts while higher concentrations beyond a threshold tend to inhibit innovative efforts. Similar inverted-U relationship has been recently identified by Aghion et al. (2005). In a UK panel data investigation where innovation and competition are measured as average weighted patents and the Lerner index respectively, Aghion et al. (2005) found an inverted-U relationship between product market competition and innovation. The authors argue that industries with low technological gaps tend to have firms that are 'neck-to-neck' and competition in these industries tend to lead to lower 'pre-innovation rents.' As a result, incumbent firms try to 'escape-competition' by increasing the technological gap and 'post-innovation rents' through innovations. Reversely, 'leader-laggard' firms dominate industries with higher technological gaps. Higher product market competition in these industries with 'leader-laggard' firms tend to reduce 'post-innovation rents' of leaders resulting in the dominance of the 'Schumpetarian effect' (Aghion et al., 2005, p. 702).

One major criticism of the literature reviewed above remains that, majority of the studies concentrate on developed countries where competition is essentially nondualistic. This chapter departs from this literature by analysing a different type of competition, that is, informal competition. Most of the available literature also measures competition only at the industry-level. We argue that informal competition is also 'local'.

As noted, this chapter departs by analysing competition from a dualistic perspective where we considered informal competition. There is a growing body of literature understandably from Latin America and Africa on informal competition and the effect of informal competition on the performance of formal firms. Employing mainly cross-sectional data from the World Bank's Enterprise Survey, some of these empirical works find informal competition and the activities of informal enterprises detrimental to the performance of formal firms and the economy as a whole (Gonzalez and Lamanna, 2007; La Porta and Shleifer, 2008; Friesen and Wacker, 2013). Informal competition is found to most adversely affect formal firms that are: small (Gonzalez and Lamanna, 2007; Ali and Najman, 2015); financially constrained (Friesen and Wacker, 
2013); tax constrained and in industries with high entry cost, low capital and higher regulations (Gonzalez and Lamanna, 2007; Friesen and Wacker, 2013). On the contrary, Ali and Najman (2015) found informal competition has productivity enhancing effects. Using the ES for 33 SSA countries, the authors found that formal firms with higher informal competition tend to increase their productivity with these effects increasing for large firms. In a cross-country analysis of Latin and African countries, using average regional measure for informal competition, Mendi and Costamagna (2017) 4 found an inverted-U relationship where informal competition has decreasing and increasing effects on the probability of introducing innovations at higher and lower intensities of competition respectively. While these studies provide some evidence on the effect of informal competition on the performance of formal firms, the evidence remains mixed. Evidence relating the effect of industry-level perception of informal competitive behaviour on the performance of product innovations also remains missing in the literature. Mendi and Costamagna (2017) considered the effect of informal competition on the probability of introducing product and process innovations. Our analysis goes further, by considering the performance of product innovations as well as using rigorous econometric approaches to provide a much deeper insight into the relationship.

\subsection{METhOdOLOGY}

\subsubsection{Empirical model}

The Enterprise Survey (ES) methodology, as noted, randomly stratifies firms by sector, size and location, which are assumed to be 'exhaustive' and 'non-overlapping'. However, the number of firms sampled in each stratum (sector, size and location) and across these strata are non-random, resulting in non-random total sample size (Wooldridge, 2002). In addition, a firm's decision to introduce product innovations onto the market is not random but often influenced by plethora of confounders. As a result of the non-random nature of the decision to introduce product innovations and the sampling design used in the ES, employing OLS may give inconsistent estimates due to the likely selection bias (see Heckman, 1979; Wooldridge, 2002). The empirical literature also recognises bi-directional causality between innovation and competition and the need to resolve the possible endogeneity bias (see Aghion et al., 2005). The ES firm-level data regarding the product market competitive behaviour of informal enterprises are mainly perception data and have been found to be highly subjective and may bias estimates (see Mendi and Costamagna, 2017; Ali and Najman, 2015;

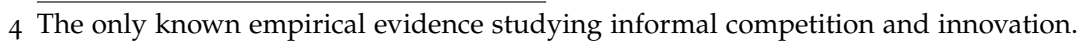


Friesen and Wacker, 2013; Gonzalez and Lamanna, 2007) as bad performing formal firms are more likely to exaggerate the competitive behaviour of informal enterprises more than good performing firms.

This section addresses the above possible biases by employing two main econometric approaches to estimate the effect of informal competition on the percentage sales from all innovative products of formal firms. At the first level of estimation, we employ a two-step methodology developed by Guiso et al. (2004) to construct 'local' and industry-level (in extension) informal competition indicators to address the possible endogeneity and subjectivity in the data. At the second level of estimation, we employ Type II Tobit model (Amemiya, 1985) to estimate the effect of our informal indicators (normalised marginal probabilities) on percentage sales from all innovative products and other relevant covariates controlling for self-selection and sample selection biases.

\subsubsection{A Model specifications}

\section{First-level estimation: 'Local' informal competition indicator construction}

To construct our 'local' informal competition indicator, we employ the two-step econometric procedure developed by Guiso et al. (2004). As noted, the standardised ES collects firm-level perception data on the product market competitive behaviour of informal enterprises. These perception responses from formal firms have been found to be highly subjective (Ali and Najman, 2015; Friesen and Wacker, 2013). As a result, using local (regional) averaged responses where firms operating in the same locality (region) have the same informal competition indicator allows for variations across regions within the same country. This has been found to mitigate the subjective bias and measurement errors in the data as well as reduce the bi-directional relationship between informal competition and innovation (see Ali and Najman, 2015; Friesen and Wacker, 2013).

Following Gonzalez and Lamanna (2007) and Guiso et al. (2004), we assume informal competition is at first only 'local' with informal enterprises competing only in their immediate vicinities. That is, enterprises operate in their immediate product markets with no or very little competitive interaction in national and/or global product markets. Several questions in the standardised ES seek to find out how formal firms perceive the competitive behaviours of both formal and informal businesses. In the construction of our 'local' informal competition indicator, we employ data on the question: Do you think the practices of competitors in the informal sector present:
a) No obstacle
b) Minor obstacle
c) Moderate obstacle
d) Major obstacle
e) Very severe obstacle... 
to the current operations of your establishment?

In the ES data set, this question is further summarised into: Percentage (\%) of firms identifying competitors in the informal sector as a major constraint. This latter question presents a binary classification that takes the value 1 if the firm considers the competitive practices of informal enterprises as a major and a very severe obstacle and the value $o$ if the firm considers the competitive practices of informal enterprises as no, minor and moderate obstacles respectively. Following Guiso et al. (2004), we use the binary classification to formalise a non-linear regression equation as:

$$
\text { Informal_competition }_{i q j}=\gamma_{0}+\gamma_{q j} \text { Region }_{q j}+\gamma_{2} X_{i q j}+\gamma_{I}+\gamma_{c}+\epsilon_{i j}
$$

where Informal_competition iqj $_{\text {in }}$ is a binary variable taking the value 1 if firm $i$ in country $j$ considers the competitive practices of informal enterprises as a major obstacle and value o if firm $i$ in country $j$ considers the competitive practices of informal enterprises as no obstacle. Region $q j$ is our 'local' informal competition variable which is a list of regional dummies in country $j$. In line with Gonzalez and Lamanna (2007) and Ali and Najman (2015), $X_{i q j}, \gamma_{I}$ and $\gamma_{c}$ are vectors of all firm, industry and country specific variables that respectively, explain firms' perception of informal market competitive behaviour. Due to differences in law enforcement in the capital city and the region as a whole, we specifically control for whether the firm is located in the capital city or otherwise. The hypothesis is that firms located in the capital city would tend to perceive informal competition less of a constraint. 5

The marginal coefficients from the first-level probit regression of equation (3.11) are shown in Table B.I in the appendix. The results indicate that foreign-owned firms are less likely to identify the competitive practices of informal enterprises as a major constraint as compared to domestic firms, all other factors held constant. This is in line, as foreign owned firms tend to serve upscale markets and usually do not compete directly with informal enterprises. Firms with financial constraints tend to consider informal competition as a major obstacle. The probability that formal firms identify the competitive activities of informal enterprises as a major constraint increases if other obstacles to business such as corruption and crime are present. The results also indicate that firms located in the capital city consider informal competition less a major constraint as compared to firms located elsewhere, satisfying our hypothesis. Firms with higher percentage increase in total sales from the previous fiscal year are also less probable to perceive informal competition as a major constraint, indicating the importance of market size.

In the second stage, we predict the marginal probabilities of Region $n_{q j}$ from the estimation of equation (3.11) with firms operating in the same vicinity having the same informal competition intensity (marginal probabilities). ${ }^{6}$ The marginal probabilities in

5 See Appendix B.1 for definition of all terms and variables.

6 Accra was used automatically as the base outcome. 
region $q$ located in country $j$ is then normalised to values between o and 1 with firms having the least informal competition intensity assigned the value o while the region with the highest informal competition intensity is assigned the value 1 . This is done formally by following Guiso et al. (2004) and Ali and Najman (2015) as:

$$
\operatorname{IPMC} C_{q j}=\left[\hat{\gamma}_{q j}-\min \left(\hat{\gamma}_{q j}\right)\right] /\left[\max \left(\hat{\gamma}_{q j}\right)-\min \left(\hat{\gamma}_{q j}\right)\right]
$$

where $I P M C_{q j}$ is 'local' informal competition indicator of region $q$ in country $j \cdot \hat{\gamma}_{q j}$ are the marginal probabilities of region $q$ in country $j \cdot \max \left(\hat{\gamma}_{q j}\right)$ and $\min \left(\hat{\gamma}_{q j}\right)$ refer to the maximum and minimum marginal probabilities respectively. Equation (3.21) normalises our 'local' informal competition indicator into a range between o and 1 where values close to 1 indicate intense informal competition and values close to 0 indicating less informal competition in the vicinity.

Description of our regional variable, country of location and their respective 'local' informal competition indicators in percentages are presented in Table 3.1. A look on Table 3.1 shows varying intensities of our 'local' informal competition indicator across different regions of the same country. Lira in Uganda has the least intensity of 'local' informal competition while Lusaka is found to have the highest intensity of 'local' informal competition. In Tanzania, for example, Arusha has the least intensity of informal competition of about 3.1\% while Zanzibar has the highest intensity of informal competition of about 53\%. These regional disparities across all countries validate our use of the 'local' indicator rather than a national proxy for informal competition as we see varying levels of informal competition across regions located in the same country.

There exist disparities across countries as well as across product innovators and non-product innovators. On the average, Tanzania has the lowest intensity of informal competition of about $30 \%$ while Zambia has the highest of about $83 \%$. On the average, innovators experienced a higher intensity of informal competition of about $60 \%$ as compared to the $47 \%$ of intensity experienced by non-product innovators. This also holds across each country except in Uganda, where non-innovators tend to experience a higher intensity of informal competition of about $62 \%$ compared with $51 \%$ for innovators. Non-innovators in Uganda may be much similar to informal enterprises in terms of characteristics such as sales (market share) and as a result tend to compete intensively against informal enterprises than their innovative counterparts. Cross-country comparison indicates, on the average, that both product and non-product innovators in Zambia experienced the highest intensity of 'local' informal competition of about $85 \%$ and $81 \%$ respectively, indicating high prevalence of 'local' informal competition in Zambia (see Table 3.2). 
Table 3.1: Description of regions and indicator by country

\begin{tabular}{llccc}
\hline Country & Region & $\begin{array}{c}\text { Number of firms } \\
\text { in data }\end{array}$ & $\begin{array}{c}\text { Number of firms } \\
\text { in sample }\end{array}$ & IPMC (\%) \\
\hline Congo, D.R. & Central & 51 & 29 & 29.827 \\
& East & 95 & 60 & 16.170 \\
& South & 47 & 15 & 21.193 \\
& West & 192 & 128 & 63.265 \\
\hline Ghana & Accra & 275 & 175 & 43.485 \\
& North & 106 & 68 & 16.484 \\
& Takoradi & 54 & 26 & 32.496 \\
& Tema & 114 & 68 & 13.187 \\
\hline Tanzania & Arusha & 92 & 14 & 3.140 \\
& Dar Es Salaam & 268 & 70 & 32.810 \\
& Mwanza & 53 & 18 & 24.490 \\
& Zanzibar & 74 & 12 & 52.590 \\
\hline \multirow{6}{*}{ Uganda } & Jinja & 79 & 29 & 73.626 \\
& Kampala & 165 & 63 & 87.912 \\
& Lira & 37 & 21 & 0 \\
& Mbale & 48 & 11 & 2.512 \\
& Mbarara & 54 & 20 & 9.419 \\
& Wakiso & 66 & 29 & 57.614 \\
\hline TOTAL & Kitwe & 74 & 65 & 70.330 \\
& Livingstone & 73 & 37 & 67.033 \\
& Lusaka & 288 & 182 & 100 \\
& Ndola & 105 & 64.835 \\
\hline
\end{tabular}


Table 3.2: Description of 'local' informal competition indicator by country

\begin{tabular}{lllllll}
\hline & ALL & DRC & GH & TZ & UGA & ZAM \\
\hline 'Local' informal competition (IPMC) & & & & & & \\
All firms (Mean \%) & 52.620 & 44.185 & 31.075 & 29.934 & 55.263 & 83.368 \\
Innovators (Mean\%) & 59.567 & 45.552 & 32.053 & 32.092 & 50.729 & 84.681 \\
Non-innovators (Mean\%) & 47.346 & 43.371 & 30.614 & 29.448 & 61.933 & 81.451 \\
\hline
\end{tabular}

Note: Means (\%) are based on 1, 225 sample data.

Second level estimation- Type II Tobit model

To estimate the effect of our 'local' informal competition indicator on sales from all innovative products, we formulate a Type II Tobit model (Amemiya, 1985) procedure as:

Regression equation:

Sales $_{\text {Product_Innovationsij }}=Y_{i j}=\alpha_{0}+\alpha_{1} I P M C_{q j}+\alpha_{2} Z_{i}+\delta_{I}+\delta_{C}+\epsilon_{i j}$, if $w_{i}^{*}>0(3 \cdot 31)$

Selection equation:

Introduce $_{\text {Product_Innovationsij }}^{*}=w_{i}^{*}=\beta_{0}+\beta_{1} M_{i}+v_{i j}$, if $w_{i}^{*}>0$ and $w_{i}=$ otherwise

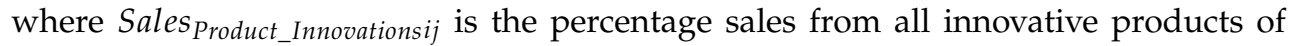
firm $i$ in country $j, I P M C_{q j}$ is our 'local' informal competition indicator in region $q$ of country $j . Z_{i}$ is the set of control covariates. $\delta_{I}$ and $\delta_{c}$ are industry-specific and country specific covariates that may affect the percentage sales from all innovative products. Introduce ProductInnovationsij ${ }^{*}$ is a latent dummy which takes value 1 if firm $i$ in country $j$ introduced product innovations over the last three (3) fiscal years and o if otherwise. $M_{i}$ is a set of control covariates that might affect firm $i$ in country $j$ to introduce product innovations and vice versa. $\epsilon_{i j}$ and $v_{i j}$ are both multivariate normally distributed error terms. $Z_{i}$ and $M_{i}$ are defined in accordance with Mendi and Costamagna (2017).

\subsubsection{B Estimation}

To estimate the Type II Tobit models, we employed the 'flexible' conditional mixed process ( $\mathrm{cmp}$ ) Stata command which performs a limited-information maximum likelihood estimation by assuming the errors from both the regression and selection equations 
can be correlated and are multivariate normally distributed (see Roodman, 2011). The parameters obtained from the simultaneous estimation of both the regression and selection equations have been found to be 'generally more efficient' due to the use of the full covariance structure in both equations (Roodman, 2011). All variance-covariance matrices are clustered at the region.

\subsubsection{Data}

The main data sets used for the empirical investigation in this chapter come from the Enterprise Survey (ES) and the Innovation Follow-Up Survey (IFS) of the World Bank. The ES follows a standard methodology to collect representative enterprise data in 122 countries, allowing for cross-country comparisons. The methodology randomly stratifies firms by sector, size and location thus making the sample in each country representative. The IFS is a representative firm-level data on innovation and innovation activities of firms interviewed during the ES. The IFS is, therefore, a follow-up survey to the ES and covered 19 countries between 2011-2014, out of which 15 of the countries covered are in Africa. In this chapter, we employ data for 5 SSA countries: Democratic Republic of Congo (DRC), Ghana (GH), Tanzania (TZ), Uganda (UG) and Zambia (ZAM).

The descriptive statistics from our sample data are shown in Table 3.3. Out of 1,225 firms in our sample, 1,220 responded to introducing product innovation or otherwise. A total of 533 firms, constituting about $43.7 \%$, introduced product innovation while 687 firms, making up about $56.3 \%$, did not introduce any product innovation. The average percentage sales from all product innovation across all countries under consideration is about $34.55 \%$ with Zambia having the least average percentage sales from all product innovation of about $26.09 \%$. Out of 1,225 responding firms, $39.1 \%$ consider competition from informal enterprises as a major constraint. Country-specific descriptive, however, show varying perceptions with about $50.14 \%$ and $24.04 \%$ of Zambian and Ghanaian firms, respectively, identifying informal competition as a major constraint to their businesses. Table 3.3 also shows the sectoral and size distributions of our data. Majority of firms $(66.12 \%)$ in our data are classified as small, with total number of workers between 5 and 19. Sectoral distributions also show almost equal proportions of about $51 \%$ and $49 \%$ for manufacturing and service sector firms, respectively. 
Table 3.3: Descriptive statistics of data by country

\begin{tabular}{lrlllll}
\hline & ALL & DRC & GH & TZ & UGA & ZAM \\
\hline Product innovations & & & & & & \\
$\quad$ No. of all firms ${ }^{a}$ & 1,220 & 230 & 334 & 114 & 173 & 369 \\
$\quad$ Innovators & 533 & 90 & 100 & 21 & 103 & 219 \\
$\quad$ Non-innovators & 687 & 140 & 234 & 93 & 70 & 150 \\
$\quad$ Sales, all product innovations (Mean\%) & 34.55 & 45.71 & 35.08 & 44.70 & 40.97 & 26.09 \\
Informal competition & & & & & & \\
$\quad$ No of all firms & 1,225 & 232 & 337 & 114 & 173 & 369 \\
$\quad$ Major obstacle (\%) & 39.10 & 38.36 & 24.04 & 47.37 & 40.46 & 50.14 \\
$\quad$ No. obstacle (\%) & 60.90 & 61.64 & 75.96 & 52.63 & 59.54 & 49.86 \\
Size of firm & & & & & & \\
$\quad$ Small (\%) & 66.12 & 68.97 & 68.55 & 53.51 & 63.01 & 67.48 \\
$\quad$ Medium (\%) & 26.70 & 25.86 & 26.70 & 28.95 & 28.90 & 25.47 \\
$\quad$ Large (\%) & 7.18 & 5.17 & 4.75 & 17.54 & 8.09 & 7.05 \\
Sector of firm & & & & & & \\
$\quad$ Manufacturing (\%) & 50.94 & 47.84 & 51.34 & 52.63 & 53.76 & 50.68 \\
$\quad$ Services (\%) & 49.06 & 52.16 & 48.66 & 47.37 & 46.24 & 49.32 \\
\hline
\end{tabular}

Source: Enterprise and Innovation Follow-Up Surveys.

${ }^{a}$ Note: These are lower than our total $(1,225)$ and our split samples, due to missing observations.

\subsection{EMPIRICAL RESULTS}

\subsubsection{Main results and discussion}

The empirical results from regressing our 'local' informal competition indicator on percentage sales due to all product innovations are reported in panel A of Table 3.4. Panel B of the same table shows estimation results from our selection equation where we regressed 'local' informal competition indicator on the decision to introduce product innovations. All results for both basic and extended specifications are heterokedasticity-robust standard errors. 
Table 3.4: Effect of informal competition on all product innovations

\begin{tabular}{|c|c|c|c|c|c|c|}
\hline \multirow[t]{3}{*}{ Estimation method } & \multicolumn{6}{|c|}{ Limited information maximum likelihood (LIML) } \\
\hline & \multicolumn{3}{|c|}{$\mathrm{A}$} & \multicolumn{3}{|c|}{$\mathrm{B}$} \\
\hline & (1) & (2) & (3) & (1) & (2) & (3) \\
\hline & \multicolumn{3}{|c|}{$\%$ sales, product innovation } & \multicolumn{3}{|c|}{ Introduce product innovations } \\
\hline Local competition (IPMC) (\%) & $\begin{array}{l}-0.190^{* * *} \\
(0.056)\end{array}$ & $\begin{array}{l}-0.321^{* *} \\
(0.148)\end{array}$ & $\begin{array}{l}-0.493^{* * *} \\
(0.148)\end{array}$ & $\begin{array}{l}-0.001 \\
(0.003)\end{array}$ & $\begin{array}{l}-0.002 \\
(0.006)\end{array}$ & $\begin{array}{l}-0.003 \\
(0.007)\end{array}$ \\
\hline Marketing & $\begin{array}{l}6.642^{*} \\
(3.400)\end{array}$ & $\begin{array}{l}6.379^{*} \\
(3.450)\end{array}$ & $\begin{array}{l}5.103 \\
(3.392)\end{array}$ & $\begin{array}{l}0.508^{* * *} \\
(0.127)\end{array}$ & $\begin{array}{l}0.505^{* * *} \\
(0.128)\end{array}$ & $\begin{array}{l}0.506^{* * *} \\
(0.130)\end{array}$ \\
\hline Log of sales (USD) $(-2)$ & $\begin{array}{l}-1.166 \\
(0.888)\end{array}$ & $\begin{array}{l}-1.170 \\
(0.896)\end{array}$ & $\begin{array}{l}-2.872^{* * *} \\
(1.009)\end{array}$ & $\begin{array}{l}-0.023 \\
(0.025)\end{array}$ & $\begin{array}{l}-0.022 \\
(0.025)\end{array}$ & $\begin{array}{l}-0.024 \\
(0.037)\end{array}$ \\
\hline Tax & $\begin{array}{l}-2.353 \\
(3.869)\end{array}$ & $\begin{array}{l}-2.141 \\
(3.957)\end{array}$ & $\begin{array}{l}-1.340 \\
(3.680)\end{array}$ & $\begin{array}{l}0.048 \\
(0.179)\end{array}$ & $\begin{array}{l}0.051 \\
(0.181)\end{array}$ & $\begin{array}{l}0.050 \\
(0.181)\end{array}$ \\
\hline Corruption & $\begin{array}{l}-7.053^{* * *} \\
(2.072)\end{array}$ & $\begin{array}{l}-7.114^{* * *} \\
(2.133)\end{array}$ & $\begin{array}{l}-7.046^{* * *} \\
(2.214)\end{array}$ & $\begin{array}{l}-0.173^{*} \\
(0.098)\end{array}$ & $\begin{array}{l}-0.173^{*} \\
(0.098)\end{array}$ & $\begin{array}{l}-0.173^{*} \\
(0.098)\end{array}$ \\
\hline Licensing & $\begin{array}{l}4.978^{* * *} \\
(1.763)\end{array}$ & $\begin{array}{l}4.954^{* * *} \\
(1.788)\end{array}$ & $\begin{array}{l}5.060^{* * *} \\
(1.742)\end{array}$ & $\begin{array}{l}0.164^{*} \\
(0.098)\end{array}$ & $\begin{array}{l}0.165^{*} \\
(0.098)\end{array}$ & $\begin{array}{l}0.164^{*} \\
(0.097)\end{array}$ \\
\hline Log of labour cost per worker (USD) & $\begin{array}{l}-0.544 \\
(0.832)\end{array}$ & $\begin{array}{l}-0.501 \\
(0.836)\end{array}$ & $\begin{array}{l}-0.768 \\
(0.855)\end{array}$ & $\begin{array}{l}0.024 \\
(0.035)\end{array}$ & $\begin{array}{l}0.024 \\
(0.035)\end{array}$ & $\begin{array}{l}0.024 \\
(0.035)\end{array}$ \\
\hline Log of total employment $(-2)$ & $\begin{array}{l}1.067 \\
(1.616)\end{array}$ & $\begin{array}{l}1.134 \\
(1.642)\end{array}$ & $\begin{array}{l}0.630 \\
(1.543)\end{array}$ & $\begin{array}{l}0.125^{* * *} \\
(0.048)\end{array}$ & $\begin{array}{l}0.124^{* * *} \\
(0.048)\end{array}$ & $\begin{array}{l}0.124^{* * *} \\
(0.047)\end{array}$ \\
\hline Log of experience & $\begin{array}{l}-3.586^{*} \\
(1.884)\end{array}$ & $\begin{array}{l}-3.579^{*} \\
(1.922)\end{array}$ & $\begin{array}{l}-3.731^{* *} \\
(1.709)\end{array}$ & $\begin{array}{l}0.067 \\
(0.117)\end{array}$ & $\begin{array}{l}0.066 \\
(0.117)\end{array}$ & $\begin{array}{l}0.066 \\
(0.116)\end{array}$ \\
\hline Support & $\begin{array}{l}7.811^{*} \\
(4.700)\end{array}$ & $\begin{array}{l}7 \cdot 722 \\
(4 \cdot 723)\end{array}$ & $\begin{array}{l}8.888^{* *} \\
(4.415)\end{array}$ & $\begin{array}{l}0.054 \\
(0.324)\end{array}$ & $\begin{array}{l}0.055 \\
(0.324)\end{array}$ & $\begin{array}{l}0.053 \\
(0.320)\end{array}$ \\
\hline Log of age & $\begin{array}{l}16.228^{*} \\
(9.057)\end{array}$ & $\begin{array}{l}15.974^{*} \\
(9.129)\end{array}$ & $\begin{array}{l}16.500^{*} \\
(8.570)\end{array}$ & $\begin{array}{l}0.562^{*} \\
(0.291)\end{array}$ & $\begin{array}{l}0.560^{*} \\
(0.290)\end{array}$ & $\begin{array}{l}0.556^{*} \\
(0.294)\end{array}$ \\
\hline Log of age squared & $\begin{array}{l}-3.089^{*} \\
(1.671)\end{array}$ & $\begin{array}{l}-3.052^{*} \\
(1.662)\end{array}$ & $\begin{array}{l}-3.238^{* *} \\
(1.546)\end{array}$ & $\begin{array}{l}-0.098 \\
(0.064)\end{array}$ & $\begin{array}{l}-0.098 \\
(0.064)\end{array}$ & $\begin{array}{l}-0.097 \\
(0.065)\end{array}$ \\
\hline IPMC squared & & $\begin{array}{l}0.001 \\
(0.001)\end{array}$ & $\begin{array}{l}0.001 \\
(0.002)\end{array}$ & & $\begin{array}{l}0.000 \\
(0.000)\end{array}$ & $\begin{array}{l}0.000 \\
(0.000)\end{array}$ \\
\hline $\mathrm{IPMC}^{*}$ Log of sales (USD) $(-2)$ & & & $\begin{array}{l}0.037^{* * *} \\
(0.014)\end{array}$ & & & $\begin{array}{l}0.000 \\
(0.001)\end{array}$ \\
\hline R\&D & & & & $\begin{array}{l}0.588^{* * *} \\
(0.081)\end{array}$ & $\begin{array}{l}0.589^{* * *} \\
(0.082)\end{array}$ & $\begin{array}{l}0.591^{* * *} \\
(0.079)\end{array}$ \\
\hline $\operatorname{sig\_ 1}$ & $\begin{array}{l}19.956^{* * *} \\
0.796\end{array}$ & $\begin{array}{l}19.929^{* * *} \\
0.817\end{array}$ & $\begin{array}{l}19.827^{* * *} \\
0.852\end{array}$ & & & \\
\hline rho_12 & $\begin{array}{l}-0.206^{* * *} \\
0.009\end{array}$ & $\begin{array}{l}-0.202^{* * *} \\
0.006\end{array}$ & $\begin{array}{l}-0.228^{* * *} \\
0.010\end{array}$ & & & \\
\hline $\mathrm{N}$ & 969 & 969 & 969 & & & \\
\hline Wald chi $^{2}$ & 4428.43 & 2779.89 & 6984.64 & & & \\
\hline Prob $>\mathrm{chi}^{2}$ & 0.000 & 0.000 & 0.000 & & & \\
\hline
\end{tabular}

Notes: Robust standard errors in parentheses, ${ }^{*} \mathrm{p}<0.10,{ }^{* *} \mathrm{p}<0.05,{ }^{* * *} \mathrm{p}<0.01$.

Used cmp Stata package for LIML estimation. All standard errors are adjusted for 22 clusters in Region.

All regressions include country, size of locality, sector, crime, foreign ownership and 23 industry dummies. 
Our main result from panel A (2) of Table 3.4 shows informal competition in product markets have a significantly negative effect on the performance of product innovations. That is, increase in the concentration of informal activities in the immediate vicinity of formal firms reduce the percentage of sales from all newly introduced product innovations. This result is in line with the empirical findings of Hashmi (2013). One explanation for this 'Schumpeterian effect', may be due to the increasing capability of informal enterprises to imitate new technological products introduced by formal firms. This result may also be explained, by the increase in the non-competitive interactions between few formal firms and informal enterprises, mainly through collaborations and outsourcing of economic activities. These non-competitive interactions may be enabling few registered firms to expand their market size through informal enterprises by taking strategic advantage of the dynamic behaviours as well as the 'local' market acceptance of these unregistered enterprises. As a result, formal firms without these non-competitive interactions may face intensive competition from informal enterprises who happen to be most active and visible competitors in product markets with similar 'imitated' products. These market behaviours may be eroding the competitive advantage formal firms without non-competitive interactions enjoy with vertical product differentiation resulting in lower sales of product innovations. This result may also partially explain the recent persistence of the growth and economic relevance of the informal sector in SSA. In panel B(2), our results also show insignificant effect of informal competition on the probability of introducing product innovation. This suggests that informality of the product market is irrelevant when firms are deciding whether to introduce product innovations or otherwise.

To test the inverted- $U$ relationship between informal competition and innovation, found recently by Mendi and Costamagna (2017), we introduced a squared term into our regressions. Results in panels $\mathrm{A}(2)$ and $\mathrm{B}(2)$ indicate insignificant effect of our informal competition squared term. These results are contrary to that of Mendi and Costamagna (2017) who found inverted-U relationship between informal competition and firms' incentives to introduce innovations. Our result, however, justifies our claim that firms are more concerned with how product innovations perform in the face of informal competition rather than on the decision to introduce innovations.

To understand the main transmission mechanisms through which 'local' informal competition affect the performance of product innovations, we interacted our informal competition indicator with log of total sales lagged. Our results show growth in total sales tends to mitigate the negative effect of informal competition on the performance of product innovations. This may be due to the growing strategic collaboration between formal firms and informal enterprises with informal enterprises working to boost sales of new innovative products introduced by collaborators in the formal economy, particularly in the retail sector. As a result of this strategic interactions, the introduction of new vertically differentiated products perform better in sales even with increased informal competition, holding all other variables constant. As noted by Blundell et al. (1999), some firms introduce and sell more of innovative products 
because they have 'marketing advantages' as compared with other firms. We verified this assertion by introducing a marketing dummy that captures whether a firm used services of marketing firm or consumer research firm or an advertising firm. Our results show firms that employed marketing services actually perform better with sales of innovative products (panels A1-A2) and are more likely to introduce product innovations (panels $\left.\mathrm{B}_{1}-\mathrm{B}_{3}\right)$.

\subsubsection{Extensions to sector, size and ownership}

We extend our analysis to examine the effect of 'local' informal competition between: manufacturing versus service sector firms; domestically owned firms; and small versus medium-sized firms. The empirical results are reported in Tables 3.5, 3.6 and 3.7.

The standardised results showing the effect of informal competition on the percentage sales due to all product innovations of manufacturing and service sector firms are presented in Table 3.5. Results show that informal competition in product markets affect negatively the performance of product innovations introduced by formal firms, both in the manufacturing and service sectors. One explanation for this result may be that majority of formal enterprises in both sectors operate at low levels of technology. As a result, informal firms are capable of imitating new products introduced onto the product market resulting in higher competition and hence weak performance of new products. We, however, found the negative effect of 'local' informal competition to be greater on service sector firms as compared to manufacturing sector firms. An explanation for the differences in the effect on manufacturing and service firms may be due to the differences in the level of technologies used. The service sector generally employs low levels of technology and requires less know-how and hence easy to 'imitate'. Manufacturing sector, however, requires a higher level of technology and technical know-how and as a result may be experiencing lower levels of 'imitations', coupled with higher levels of collaboration with the informal economy. This may be leading to the better performance of product innovations from the manufacturing sector as compared with other service and retail sectors. These results are robust across all specifications.

Our results also show manufacturing firms that experienced higher sales from three fiscal years ago and do not perceive corruption as an obstacle tend to sell more of all newly introduced product innovations with increases in the intensity of informal competition holding other factors constant, than otherwise. This result means that market size is relevant for the performance of product innovations. The results also show manufacturing firms that perceive and identify corruption as a major obstacle to their business tend to sell less of all newly introduced product innovations with increases in the intensity of informal competition even with gains in market share, holding other factors constant. We find similar indirect mechanisms of sales for service sector 
firms as well. However, we find the indirect sales mechanism to be much effective in the manufacturing sector than in the service sector. That is, manufacturing sector firms that experienced higher intensity of informal competition tend to sell more of all newly introduced product innovations with increases in sales from three fiscal years ago, holding other factors constant, than compared with service firms. ${ }^{7}$ In other words, manufacturing sector firms with larger market power tend to perform better with new product innovations with increases in informal competition as compared to service sector firms. This may also be due to the differences in non-competitive interactions with the informal economy.

Table 3.6 presents the regression results showing the effect of informal competition on domestic-owned firms. ${ }^{8}$ Results reveal negative effect of informal competition on the performance of all product innovations introduced by firms owned locally. We failed to find any indirect mechanisms.

Regression results from our size of firm analysis are presented in Table 3.7, with panels A and B showing the basic and extended results for small-sized and mediumsized firms, respectively. We find statistically negative effect of informal competition on both small and medium-sized firms (columns $\mathrm{A}_{1}$ and $\mathrm{B}_{4}$ ). We also find similar indirect mechanisms where medium-sized firms that experienced higher sales from three fiscal years ago tend to sell more of all product innovation with increases in the intensity of informal competition, holding other factors constant, than otherwise. The significantly negative effect of informal competition on the innovative sales of smallsized firms, however, disappears with the inclusion of cross terms (columns A2 and A3). We also found statistically insignificant effects of the cross-terms, suggesting the absence of indirect mechanisms for small-sized firms.

\subsubsection{Extension to industry-level informal competition}

In extending the analysis to the industry-level ${ }^{9}$, we followed the two-step econometric procedure presented above in equations (3.11) and (3.21) to construct industry-level informal competition indicator. The industry-level indicator is normalised between 0 and 1 with industries in a country having the least informal competition intensity assigned the value o while the industry with the highest informal competition intensity assigned the value 1 . This enables us to capture the variations in industry-level infor-

7 See Table 3.5 panels 3 and 5 .

8 We also attempted seperate regressions for foreign-owned firms as well as firms engaged in export activity. Due to the small sample size of both exporters (59) and foreign-owned firms (175) in our data, we failed to obtain estimates for these regressions.

9 See Table B.2 in appendix for list of industries and industry classifications. 
Table 3.5: Sectoral analysis of the effect of informal competition on \% sales, all product innovations

\begin{tabular}{|c|c|c|c|c|c|}
\hline \multirow[t]{3}{*}{ Estimation method } & \multicolumn{5}{|c|}{ Limited information maximum likelihood (LIML) } \\
\hline & \multicolumn{3}{|c|}{ Manufacturing } & \multicolumn{2}{|c|}{ Services } \\
\hline & (1) & (2) & (3) & (4) & (5) \\
\hline & \multicolumn{5}{|c|}{$\%$ sales, product innovations } \\
\hline Local competition (IPMC) (\%) & $\begin{array}{l}-0.274^{* * *} \\
(0.060)\end{array}$ & $\begin{array}{l}-0.109 \\
(0.067)\end{array}$ & $\begin{array}{l}-0.365^{* *} \\
(0.157)\end{array}$ & $\begin{array}{l}-0.241^{* * *} \\
(0.072)\end{array}$ & $\begin{array}{l}-0.643^{* * *} \\
(0.185)\end{array}$ \\
\hline Marketing & & $\begin{array}{l}1.403 \\
(3.179)\end{array}$ & $\begin{array}{l}0.194 \\
(3.098)\end{array}$ & $\begin{array}{l}17.897^{* * *} \\
(3.538)\end{array}$ & $\begin{array}{l}15.152^{* * *} \\
(4.571)\end{array}$ \\
\hline Log of sales (USD) (-2) & & $\begin{array}{l}-1.372 \\
(0.872)\end{array}$ & $\begin{array}{l}-2.935^{* *} \\
(1.272)\end{array}$ & $\begin{array}{l}-1.167 \\
(0.964)\end{array}$ & $\begin{array}{l}-2.393^{* *} \\
(1.126)\end{array}$ \\
\hline Tax & & $\begin{array}{l}-5.576 \\
(6.663)\end{array}$ & $\begin{array}{l}-4.624 \\
(6.591)\end{array}$ & $\begin{array}{l}3.078 \\
(5.211)\end{array}$ & $\begin{array}{l}3.069 \\
(4.700)\end{array}$ \\
\hline Corruption & & $\begin{array}{l}-5.873^{* *} \\
(2.968)\end{array}$ & $\begin{array}{l}-5.602^{* *} \\
(2.753)\end{array}$ & $\begin{array}{l}-5.759 \\
(3.576)\end{array}$ & $\begin{array}{l}-7.500 \\
(5.475)\end{array}$ \\
\hline Licensing & & $\begin{array}{l}2.957 \\
(2.046)\end{array}$ & $\begin{array}{l}2.995 \\
(1.943)\end{array}$ & $\begin{array}{l}5.680 \\
(5.048)\end{array}$ & $\begin{array}{l}6.435 \\
(5.317)\end{array}$ \\
\hline Crime & & $\begin{array}{l}2.440 \\
(3.607)\end{array}$ & $\begin{array}{l}0.550 \\
(3.490)\end{array}$ & $\begin{array}{l}-12.767^{* * *} \\
(3.370)\end{array}$ & $\begin{array}{l}-12.565^{* * *} \\
(3.354)\end{array}$ \\
\hline Log of labour cost per worker (USD) & & $\begin{array}{l}0.713 \\
(1.007)\end{array}$ & $\begin{array}{l}1.044 \\
(1.014)\end{array}$ & $\begin{array}{l}-1.627 \\
(1.001)\end{array}$ & $\begin{array}{l}-2.154^{* *} \\
(0.907)\end{array}$ \\
\hline Log of total employment $(-2)$ & & $\begin{array}{l}3.223 \\
(2.337)\end{array}$ & $\begin{array}{l}3.538 \\
(2.392)\end{array}$ & $\begin{array}{l}-1.191 \\
(1.528)\end{array}$ & $\begin{array}{l}-1.920 \\
(1.584)\end{array}$ \\
\hline Foreign ownership & & $\begin{array}{l}3.355 \\
(4.648)\end{array}$ & $\begin{array}{l}3 \cdot 329 \\
(4.523)\end{array}$ & $\begin{array}{l}0.453 \\
(5.158)\end{array}$ & $\begin{array}{l}0.358 \\
(5.011)\end{array}$ \\
\hline Log of experience & & $\begin{array}{l}-5.442 \\
(3.988)\end{array}$ & $\begin{array}{l}-4.850 \\
(3.808)\end{array}$ & $\begin{array}{l}-2.987 \\
(2.948)\end{array}$ & $\begin{array}{l}-3.348 \\
(2.870)\end{array}$ \\
\hline Support & & $\begin{array}{l}-1.899 \\
(7.399)\end{array}$ & $\begin{array}{l}-0.291 \\
(6.295)\end{array}$ & $\begin{array}{l}9.221 \\
(7.485)\end{array}$ & $\begin{array}{l}10.541 \\
(7.006)\end{array}$ \\
\hline Log of age & & $\begin{array}{l}32.802^{* * *} \\
(11.687)\end{array}$ & $\begin{array}{l}34.334^{* * *} \\
(10.547)\end{array}$ & $\begin{array}{l}13.850 \\
(11.795)\end{array}$ & $\begin{array}{l}13.944 \\
(11.762)\end{array}$ \\
\hline Log of age squared & & $\begin{array}{l}-5.609^{* * *} \\
(2.105)\end{array}$ & $\begin{array}{l}-6.076^{* * *} \\
(1.983)\end{array}$ & $\begin{array}{l}-3.800^{*} \\
(2.076)\end{array}$ & $\begin{array}{l}-3.768^{*} \\
(2.046)\end{array}$ \\
\hline $\mathrm{IPMC}^{*}$ Log of sales (USD) $(-2)$ & & & $\begin{array}{l}0.026^{*} \\
(0.014)\end{array}$ & & $\begin{array}{l}0.033^{* *} \\
(0.016)\end{array}$ \\
\hline IPMC* Corruption & & & $\begin{array}{l}-0.148^{* *} \\
(0.061)\end{array}$ & & $\begin{array}{l}0.031 \\
(0.107)\end{array}$ \\
\hline Country fixed effects & No & Yes & Yes & Yes & Yes \\
\hline $\mathrm{N}$ & 508 & 508 & 508 & 461 & 461 \\
\hline Wald chi ${ }^{2}$ & 1162.87 & 1438.43 & 1463.80 & 1036 & 1034 \\
\hline Prob $>$ chi $^{2}$ & 0.000 & 0.000 & 0.000 & 0.000 & 0.000 \\
\hline
\end{tabular}

Notes: Robust standard errors in parentheses, ${ }^{*} \mathrm{p}<0.10,{ }^{* *} \mathrm{p}<0.05,{ }^{* * *} \mathrm{p}<0.01$.

Used cmp Stata package for LIML estimation. All standard errors are adjusted for 22 clusters in Region. All standard errors are robust to heteroskedasticity.

All regressions include size of locality and 23 industry dummies. 
Table 3.6: Effect of informal competition on \% sales, all product innovations: Domestic ownership

\begin{tabular}{|c|c|c|c|}
\hline \multirow[t]{2}{*}{ Estimation method } & \multicolumn{3}{|c|}{ Limited-information maximum likelihood (LIML) } \\
\hline & $(1)$ & $(2)$ & (3) \\
\hline & \multicolumn{3}{|c|}{$\%$ sales, product innovations } \\
\hline \multirow[t]{2}{*}{ Local competition (IPMC) (\%) } & $-0.192^{* * *}$ & $-0.361^{* *}$ & $-0.361^{* *}$ \\
\hline & $(0.053)$ & $(0.147)$ & $(0.149)$ \\
\hline \multirow[t]{2}{*}{ Marketing } & $7.083^{* *}$ & $6.307^{*}$ & $6.247^{*}$ \\
\hline & $(3.274)$ & $(3.261)$ & $(3.249)$ \\
\hline \multirow[t]{2}{*}{ Log of sales (USD) (-2) } & $-1.745^{* *}$ & $-2.363^{* *}$ & $-2.428^{* * *}$ \\
\hline & $(0.831)$ & $(0.922)$ & $(0.927)$ \\
\hline \multirow[t]{2}{*}{ Tax } & 1.637 & 1.839 & 1.909 \\
\hline & $(4 \cdot 571)$ & $(4 \cdot 402)$ & $(4.430)$ \\
\hline \multirow[t]{2}{*}{ Corruption } & $-6.555^{* * *}$ & $-6.645^{* * *}$ & -4.637 \\
\hline & $(1.588)$ & $(1.626)$ & $(3.319)$ \\
\hline \multirow[t]{2}{*}{ Licensing } & $3 \cdot 512^{*}$ & $3 \cdot 375^{*}$ & $3 \cdot 403^{*}$ \\
\hline & $(1.819)$ & $(1.813)$ & $(1.816)$ \\
\hline \multirow[t]{2}{*}{ Crime } & -2.189 & -2.444 & -2.613 \\
\hline & $(2.878)$ & $(2.900)$ & $(2.922)$ \\
\hline \multirow[t]{2}{*}{ Log of labour cost per worker (USD) } & 0.101 & 0.057 & 0.080 \\
\hline & $(0.916)$ & $(0.936)$ & (o.949) \\
\hline \multirow[t]{2}{*}{ Log of total employment (-2) } & 2.238 & 2.119 & 2.181 \\
\hline & $(1.480)$ & $(1.482)$ & $(1.517)$ \\
\hline \multirow[t]{2}{*}{ Log of experience } & -3.794 & -3.881 & -3.888 \\
\hline & $(3.410)$ & $(3 \cdot 347)$ & $(3 \cdot 324)$ \\
\hline \multirow[t]{2}{*}{ Support } & 8.050 & 8.314 & 8.514 \\
\hline & $(5.682)$ & $(5 \cdot 520)$ & $(5 \cdot 469)$ \\
\hline \multirow[t]{2}{*}{ Log of age } & $23 \cdot 560^{* *}$ & $23.190^{*}$ & $23 \cdot 580^{* *}$ \\
\hline & $(11.970)$ & $(11.983)$ & $(11.675)$ \\
\hline \multirow[t]{2}{*}{ Log of age squared } & $-4.655^{* *}$ & $-4.624^{* *}$ & $-4 \cdot 708^{* *}$ \\
\hline & $(2.225)$ & $(2.216)$ & $(2.156)$ \\
\hline \multirow[t]{2}{*}{ IPMC* Log of sales (USD) (-2) } & & 0.014 & 0.015 \\
\hline & & $(0.013)$ & $(0.013)$ \\
\hline \multirow[t]{2}{*}{ IPMC* Corruption } & & & -0.038 \\
\hline & & & $(0.047)$ \\
\hline Country fixed effects & Yes & Yes & Yes \\
\hline $\mathrm{N}$ & 794 & 794 & 794 \\
\hline Wald chi ${ }^{2}$ & 7138.44 & 8657.72 & 9188.41 \\
\hline Prob $>\mathrm{chi}^{2}$ & 0.000 & 0.000 & 0.000 \\
\hline
\end{tabular}

Notes: Robust standard errors in parentheses, ${ }^{*} \mathrm{p}<0.10,{ }^{* *} \mathrm{p}<0.05,{ }^{* * *} \mathrm{p}<0.01$.

Used cmp Stata package for LIML estimation. All standard errors are adjusted for 22 clusters in Region. All standard errors are robust to heteroskedasticity.

All regressions include size of locality, sector and 23 industry dummies. 
Table 3.7: Effect of informal competition on \% sales, all product innovations: Small vrs. medium

\begin{tabular}{|c|c|c|c|c|c|c|}
\hline \multirow[t]{3}{*}{ Estimation method } & \multicolumn{6}{|c|}{ Limited information maximum likelihood (LIML) } \\
\hline & \multicolumn{3}{|c|}{ A-Small-sized } & \multicolumn{3}{|c|}{ B-Medium-sized } \\
\hline & $(1)$ & $(2)$ & (3) & (4) & (5) & (6) \\
\hline & \multicolumn{6}{|c|}{$\%$ sales, product innovations } \\
\hline Local competition (IPMC) (\%) & $\begin{array}{l}-0.205^{* * *} \\
(0.079)\end{array}$ & $\begin{array}{l}-0.397 \\
(0.258)\end{array}$ & $\begin{array}{l}-0.393 \\
(0.259)\end{array}$ & $\begin{array}{l}-0.240^{* *} \\
(0.121)\end{array}$ & $\begin{array}{l}-1.094^{* * *} \\
(0.217)\end{array}$ & $\begin{array}{l}-1.063^{* * *} \\
(0.223)\end{array}$ \\
\hline Marketing & $\begin{array}{l}14.814^{* * *} \\
(4.145)\end{array}$ & $\begin{array}{l}14.320^{* * *} \\
(3.926)\end{array}$ & $\begin{array}{l}14.167^{* * *} \\
(4.125)\end{array}$ & $\begin{array}{l}5.753^{*} \\
(3.413)\end{array}$ & $\begin{array}{l}0.874 \\
(3.744)\end{array}$ & $\begin{array}{l}0.702 \\
(3.763)\end{array}$ \\
\hline Log of sales (USD) (-2) & $\begin{array}{l}-1.239 \\
(1.203)\end{array}$ & $\begin{array}{l}-2.111 \\
(1.468)\end{array}$ & $\begin{array}{l}-2.095 \\
(1.456)\end{array}$ & $\begin{array}{l}-1.648 \\
(1.244)\end{array}$ & $\begin{array}{l}-4.718^{* * *} \\
(1.332)\end{array}$ & $\begin{array}{l}-4.761^{* * *} \\
(1.315)\end{array}$ \\
\hline Tax & $\begin{array}{l}-7.374 \\
(6.431)\end{array}$ & $\begin{array}{l}-7.090 \\
(6.575)\end{array}$ & $\begin{array}{l}-6.615 \\
(6.518)\end{array}$ & $\begin{array}{l}2.262 \\
(8.916)\end{array}$ & $\begin{array}{l}4.098 \\
(7.501)\end{array}$ & $\begin{array}{l}3.987 \\
(7.450)\end{array}$ \\
\hline Corruption & $\begin{array}{l}-9.205^{* * *} \\
(2.987)\end{array}$ & $\begin{array}{l}-9.589^{* * *} \\
(3.070)\end{array}$ & $\begin{array}{l}-7.692 \\
(5.405)\end{array}$ & $\begin{array}{l}-4.887 \\
(4.362)\end{array}$ & $\begin{array}{l}-3.838 \\
(4.121)\end{array}$ & $\begin{array}{l}-0.390 \\
(6.406)\end{array}$ \\
\hline Licensing & $\begin{array}{l}4.102 \\
(3.118)\end{array}$ & $\begin{array}{l}3.877 \\
(3.067)\end{array}$ & $\begin{array}{l}3.783 \\
(3.136)\end{array}$ & $\begin{array}{l}9.574^{*} \\
(5.260)\end{array}$ & $\begin{array}{l}11.858^{* *} \\
(5.380)\end{array}$ & $\begin{array}{l}12.119^{* *} \\
(5.376)\end{array}$ \\
\hline Crime & $\begin{array}{l}-3.491 \\
(2.955)\end{array}$ & $\begin{array}{l}-3.223 \\
(3.050)\end{array}$ & $\begin{array}{l}-3.535 \\
(3.339)\end{array}$ & $\begin{array}{l}-1.130 \\
(4.666)\end{array}$ & $\begin{array}{l}-4.478 \\
(4.633)\end{array}$ & $\begin{array}{l}-4.500 \\
(4.599)\end{array}$ \\
\hline Log of labour cost per worker (USD) & $\begin{array}{l}-0.618 \\
(1.274)\end{array}$ & $\begin{array}{l}-0.615 \\
(1.308)\end{array}$ & $\begin{array}{l}-0.617 \\
(1.306)\end{array}$ & $\begin{array}{l}-1.441 \\
(1.619)\end{array}$ & $\begin{array}{l}-1.643 \\
(1.547)\end{array}$ & $\begin{array}{l}-1.617 \\
(1.559)\end{array}$ \\
\hline Foreign ownership & $\begin{array}{l}6.609 \\
(5.474)\end{array}$ & $\begin{array}{l}6.529 \\
(5.457)\end{array}$ & $\begin{array}{l}6.463 \\
(5.356)\end{array}$ & $\begin{array}{l}-3.630 \\
(4.963)\end{array}$ & $\begin{array}{l}-1.838 \\
(5.147)\end{array}$ & $\begin{array}{l}-2.071 \\
(5.079)\end{array}$ \\
\hline Log of experience & $\begin{array}{l}-3.272 \\
(3.265)\end{array}$ & $\begin{array}{l}-3.220 \\
(3.277)\end{array}$ & $\begin{array}{l}-3.299 \\
(3.126)\end{array}$ & $\begin{array}{l}-6.664 \\
(4.642)\end{array}$ & $\begin{array}{l}-5.583 \\
(4.487)\end{array}$ & $\begin{array}{l}-5.734 \\
(4.528)\end{array}$ \\
\hline Support & $\begin{array}{l}14.695^{* * *} \\
(5.360)\end{array}$ & $\begin{array}{l}14.831^{* * *} \\
(5.392)\end{array}$ & $\begin{array}{l}14.846^{* * *} \\
(5.340)\end{array}$ & $\begin{array}{l}-0.891 \\
(10.878)\end{array}$ & $\begin{array}{l}8.818 \\
(8.841)\end{array}$ & $\begin{array}{l}8.512 \\
(8.862)\end{array}$ \\
\hline Log of age & $\begin{array}{l}17.601^{*} \\
(10.330)\end{array}$ & $\begin{array}{l}17.022 \\
(10.671)\end{array}$ & $\begin{array}{l}17.053 \\
(10.671)\end{array}$ & $\begin{array}{l}29.624 \\
(21.119)\end{array}$ & $\begin{array}{l}33.177^{*} \\
(19.534)\end{array}$ & $\begin{array}{l}33.146^{*} \\
(19.510)\end{array}$ \\
\hline Log of age squared & $\begin{array}{l}-3.279 \\
(2.066)\end{array}$ & $\begin{array}{l}-3.209 \\
(2.077)\end{array}$ & $\begin{array}{l}-3.206 \\
(2.078)\end{array}$ & $\begin{array}{l}-5.327 \\
(3.520)\end{array}$ & $\begin{array}{l}-6.212^{* *} \\
(3.115)\end{array}$ & $\begin{array}{l}-6.188^{* *} \\
(3.114)\end{array}$ \\
\hline IPMC* Log of sales (USD) (-2) & & $\begin{array}{l}0.017 \\
(0.020)\end{array}$ & $\begin{array}{l}0.018 \\
(0.021)\end{array}$ & & $\begin{array}{l}0.063^{* * *} \\
(0.018)\end{array}$ & $\begin{array}{l}0.063^{* * *} \\
(0.018)\end{array}$ \\
\hline IPMC* Corruption & & & $\begin{array}{l}-0.034 \\
(0.101)\end{array}$ & & & $\begin{array}{l}-0.066 \\
(0.082)\end{array}$ \\
\hline Country fixed effect & Yes & Yes & No & Yes & Yes & Yes \\
\hline $\mathrm{N}$ & 625 & 625 & 625 & 275 & 275 & 275 \\
\hline Wald chi ${ }^{2}$ & 713.22 & 2786.01 & 2875.28 & 4549.83 & 4507.23 & 5916.84 \\
\hline Prob $>$ chi $^{2}$ & 0.000 & 0.000 & 0.000 & 0.000 & 0.000 & 0.000 \\
\hline
\end{tabular}

Notes: Robust standard errors in parentheses, ${ }^{*} \mathrm{p}<0.10,{ }^{* *} \mathrm{p}<0.05,{ }^{* * *} \mathrm{p}<0.01$.

Used cmp Stata package for LIML estimation. All standard errors are adjusted for 22 clusters in Region. All standard errors are robust to heteroskedasticity.

All regressions include size of locality, sector and 23 industry dummies. 
mal competition across different industries in the same country as well as variations in similar industries across different countries. ${ }^{10}$

Table 3.8 presents the estimation results showing the effect of both our 'local' and industry-level informal competition indicators on the performance of product innovations. The sectoral analysis of the effect of 'local' and industry-level informal competition indicators are shown in Table 3.9. The results from both tables remain similar to the results obtained above, with 'local' informal competition having significantly negative effect on the performance of product innovations in both manufacturing and service and retail firms. The results, however, indicate a significantly positive effect of industry-level informal competition across all specifications. This implies that industries with higher concentration of informal enterprises tend to perform better in product markets with new product innovations. Sectoral analysis shown in Table 3.9 also indicates manufacturing firms tend to perform positively on product markets with increases in industry-level informal competition. This result may also be explained by the differences in the technology gap and technical know-how between the manufacturing sector and informal manufacturing enterprises, on the one hand, and between service and retail firms and informal service enterprises, on the other hand. The service sector is relatively less capital intensive and requires less technical know-how compared with the manufacturing sector. As a result, informal enterprises are more likely to easily imitate and compete with new innovative services in an industry. We, however, failed to find significant effect of industry-level informal competition in the service sector. The negative effect of industry-level competition is found in other empirical papers including Blundell, Griffith and Van Reenen (1999), Aghion et al., (2001), and Boldrin and Levine (2008).

\subsubsection{Robustness}

To further test the robustness of our results to alternative empirical specifications, we followed Friesen and Wacker (2013) by employing our 'local' informal competition indicator as an instrument for informal competition. We also estimated this model on two variants of sales from product innovations, namely percentage sales due to all product innovations, and total sales due to all product innovations in dollars. The results of all variant specifications as reported in Table B.4 (see appendix) are consistent across all specifications with our earlier results, with informal competition significantly affecting performance of product innovation negatively. That is, an increase in informal competition reduces the market performance of product innovations. ${ }^{11}$

1o See Table B.3 in appendix for description of our industry-level informal competition indicator in percentages.

11 We also tested the stability of our results by introducing industry-level informal competition indicator as a second instrument for informal competition. We, however, found similar results. 
Table 3.8: Effect of 'local' and industry-level informal competition on all product innovations

\begin{tabular}{|c|c|c|c|c|c|c|}
\hline \multirow[t]{3}{*}{ Estimation method } & \multicolumn{6}{|c|}{ Limited information maximum likelihood (LIML) } \\
\hline & \multicolumn{6}{|c|}{ ( } \\
\hline & (1) & $(2)$ & (3) & (1) & $(2)$ & (3) \\
\hline & \multicolumn{3}{|c|}{$\%$ sales, product innovation } & \multicolumn{3}{|c|}{ Introduce product innovations } \\
\hline Local competition (IPMC) (\%) & $\begin{array}{l}-0.195^{* * *} \\
(0.064)\end{array}$ & $\begin{array}{l}-0.307 \\
(0.188)\end{array}$ & $\begin{array}{l}-0.448^{* *} \\
(0.184)\end{array}$ & $\begin{array}{l}-0.000 \\
(0.003)\end{array}$ & $\begin{array}{l}-0.002 \\
(0.007)\end{array}$ & $\begin{array}{l}-0.003 \\
(0.007)\end{array}$ \\
\hline Industry competition $(\%)$ & $\begin{array}{l}0.304^{* * *} \\
(0.079)\end{array}$ & $\begin{array}{l}0.299^{* * *} \\
(0.083)\end{array}$ & $\begin{array}{l}0.320^{* * *} \\
(0.075)\end{array}$ & $\begin{array}{l}0.004 \\
(0.005)\end{array}$ & $\begin{array}{l}0.004 \\
(0.005)\end{array}$ & $\begin{array}{l}0.004 \\
(0.005)\end{array}$ \\
\hline Marketing & $\begin{array}{l}4.932 \\
(3.990)\end{array}$ & $\begin{array}{l}4.793 \\
(4.054)\end{array}$ & $\begin{array}{l}3.828 \\
(4.114)\end{array}$ & $\begin{array}{l}0.496^{* * *} \\
(0.118)\end{array}$ & $\begin{array}{l}0.493^{* * *} \\
(0.119)\end{array}$ & $\begin{array}{l}0.492^{* * *} \\
(0.122)\end{array}$ \\
\hline Log of sales (USD) (-2) & $\begin{array}{l}-1.327^{*} \\
(0.768)\end{array}$ & $\begin{array}{l}-1.340^{*} \\
(0.774)\end{array}$ & $\begin{array}{l}-2.798^{* * *} \\
(1.040)\end{array}$ & $\begin{array}{l}-0.020 \\
(0.024)\end{array}$ & $\begin{array}{l}-0.020 \\
(0.024)\end{array}$ & $\begin{array}{l}-0.028 \\
(0.040)\end{array}$ \\
\hline Tax & $\begin{array}{l}-2.213 \\
(3.992)\end{array}$ & $\begin{array}{l}-1.981 \\
(3.972)\end{array}$ & $\begin{array}{l}-1.252 \\
(3.772)\end{array}$ & $\begin{array}{l}0.030 \\
(0.185)\end{array}$ & $\begin{array}{l}0.035 \\
(0.187)\end{array}$ & $\begin{array}{l}0.035 \\
(0.187)\end{array}$ \\
\hline Corruption & $\begin{array}{l}-5 \cdot 721^{* * *} \\
(1.846)\end{array}$ & $\begin{array}{l}-5 \cdot 794^{* * *} \\
(1.880)\end{array}$ & $\begin{array}{l}-5 \cdot 779^{* * *} \\
(1.890)\end{array}$ & $\begin{array}{l}-0.191^{*} \\
(0.100)\end{array}$ & $\begin{array}{l}-0.193^{*} \\
(0.100)\end{array}$ & $\begin{array}{l}-0.192^{*} \\
(0.100)\end{array}$ \\
\hline Licensing & $\begin{array}{l}4.871^{* * *} \\
(1.745)\end{array}$ & $\begin{array}{l}4.934^{* * *} \\
(1.732)\end{array}$ & $\begin{array}{l}5.059^{* * *} \\
(1.666)\end{array}$ & $\begin{array}{l}0.178^{*} \\
(0.105)\end{array}$ & $\begin{array}{l}0.178^{*} \\
(0.105)\end{array}$ & $\begin{array}{l}0.176^{*} \\
(0.103)\end{array}$ \\
\hline Log of labour cost per worker (USD) & $\begin{array}{l}-0.622 \\
(0.852)\end{array}$ & $\begin{array}{l}-0.599 \\
(0.849)\end{array}$ & $\begin{array}{l}-0.831 \\
(0.829)\end{array}$ & $\begin{array}{l}0.012 \\
(0.034)\end{array}$ & $\begin{array}{l}0.012 \\
(0.034)\end{array}$ & $\begin{array}{l}0.013 \\
(0.034)\end{array}$ \\
\hline Log of total employment $(-2)$ & $\begin{array}{l}0.708 \\
(1.547)\end{array}$ & $\begin{array}{l}0.761 \\
(1.576)\end{array}$ & $\begin{array}{l}0.306 \\
(1.455)\end{array}$ & $\begin{array}{l}0.098^{* *} \\
(0.042)\end{array}$ & $\begin{array}{l}0.098^{* *} \\
(0.042)\end{array}$ & $\begin{array}{l}0.097^{* *} \\
(0.040)\end{array}$ \\
\hline Log of experience & $\begin{array}{l}-3.487^{* *} \\
(1.722)\end{array}$ & $\begin{array}{l}-3.421^{*} \\
(1.777)\end{array}$ & $\begin{array}{l}-3.472^{* *} \\
(1.607)\end{array}$ & $\begin{array}{l}0.040 \\
(0.111)\end{array}$ & $\begin{array}{l}0.038 \\
(0.110)\end{array}$ & $\begin{array}{l}0.039 \\
(0.109)\end{array}$ \\
\hline Support & $\begin{array}{l}7.068 \\
(4.494)\end{array}$ & $\begin{array}{l}7.019 \\
(4.504)\end{array}$ & $\begin{array}{l}7.875^{*} \\
(4.229)\end{array}$ & $\begin{array}{l}0.013 \\
(0.292)\end{array}$ & $\begin{array}{l}0.012 \\
(0.293)\end{array}$ & $\begin{array}{l}0.013 \\
(0.288)\end{array}$ \\
\hline Log of age & $\begin{array}{l}18.574^{* *} \\
(8.011)\end{array}$ & $\begin{array}{l}18.308^{* *} \\
(8.178)\end{array}$ & $\begin{array}{l}18.640^{* *} \\
(7.815)\end{array}$ & $\begin{array}{l}0.449 \\
(0.287)\end{array}$ & $\begin{array}{l}0.446 \\
(0.285)\end{array}$ & $\begin{array}{l}0.439 \\
(0.295)\end{array}$ \\
\hline Log of age squared & $\begin{array}{l}-3.659^{* *} \\
(1.450)\end{array}$ & $\begin{array}{l}-3.619^{* *} \\
(1.461)\end{array}$ & $\begin{array}{l}-3.737^{* * *} \\
(1.378)\end{array}$ & $\begin{array}{l}-0.071 \\
(0.062)\end{array}$ & $\begin{array}{l}-0.070 \\
(0.061)\end{array}$ & $\begin{array}{l}-0.069 \\
(0.063)\end{array}$ \\
\hline IPMC squared & & $\begin{array}{l}0.001 \\
(0.002)\end{array}$ & $\begin{array}{l}-0.001 \\
(0.002)\end{array}$ & & $\begin{array}{l}0.000 \\
(0.000)\end{array}$ & $\begin{array}{l}0.000 \\
(0.000)\end{array}$ \\
\hline IPMC* Log of sales (USD) (-2) & & & $\begin{array}{l}0.031^{* *} \\
(0.012)\end{array}$ & & & $\begin{array}{l}0.000 \\
(0.001)\end{array}$ \\
\hline $\mathrm{RD}$ & & & & $\begin{array}{l}0.589^{* * *} \\
(0.074)\end{array}$ & $\begin{array}{l}0.590^{* * *} \\
(0.075)\end{array}$ & $\begin{array}{l}0.594^{* * *} \\
(0.071)\end{array}$ \\
\hline Country fixed effects & Yes & Yes & Yes & Yes & Yes & Yes \\
\hline sig_1 & $19.956^{* * *}$ & $19.929^{* * *}$ & $19.827^{* * *}$ & & & \\
\hline rho_12 & $-0.206^{* * *}$ & $-0.202^{* * *}$ & $-0.228^{* * *}$ & & & \\
\hline $\mathrm{N}$ & 969 & 969 & 969 & & & \\
\hline Wald chi ${ }^{2}$ & 8116.61 & 16746.38 & 27612.80 & & & \\
\hline Prob $>$ chi $^{2}$ & 0.000 & 0.000 & 0.000 & & & \\
\hline
\end{tabular}

Notes: Robust standard errors in parentheses, ${ }^{*} \mathrm{p}<0.10,{ }^{* *} \mathrm{p}<0.05,{ }^{* * *} \mathrm{p}<0.01$.

Used cmp Stata package for LIML estimation. All standard errors are adjusted for 22 clusters in Region. All regressions include size of locality, sector, crime and foreign ownership dummies. 
Table 3.9: Sectoral analysis of local and industry-level competition on \% sales, product innovations

\begin{tabular}{|c|c|c|c|c|c|}
\hline \multirow[t]{3}{*}{ Estimation method } & \multicolumn{5}{|c|}{ Limited information maximum likelihood (LIML) } \\
\hline & \multicolumn{3}{|c|}{ Manufacturing } & \multicolumn{2}{|c|}{ Services } \\
\hline & $(1)$ & $(2)$ & (3) & $(4)$ & $(5)$ \\
\hline & \multicolumn{5}{|c|}{$\%$ sales, product innovations } \\
\hline \multirow[t]{2}{*}{ Local competition (IPMC) (\%) } & $-0.230^{* * *}$ & -0.111 & $-0.306^{*}$ & $-0.240^{* * *}$ & $-0.767^{* * *}$ \\
\hline & $(0.048)$ & $(0.084)$ & $(0.171)$ & $(0.075)$ & $(0.183)$ \\
\hline \multirow[t]{2}{*}{ Industry competition (\%) } & $0.459^{* * *}$ & $0.365^{* * *}$ & $0.372^{* * *}$ & 0.267 & 0.253 \\
\hline & $(0.095)$ & $(0.121)$ & $(0.117)$ & $(0.179)$ & $(0.159)$ \\
\hline \multirow[t]{2}{*}{ Marketing } & & -0.797 & -1.210 & $14 \cdot 368^{* * *}$ & $10.855^{* *}$ \\
\hline & & $(3.660)$ & $(3.765)$ & $(4 \cdot 331)$ & $(5.174)$ \\
\hline \multirow[t]{2}{*}{ Log of sales (USD) $(-2)$} & & $-1.707^{* *}$ & $-2.658^{* *}$ & -0.969 & $-2.674^{* *}$ \\
\hline & & $(3.179)$ & $(3.098)$ & $(3 \cdot 538)$ & $(4 \cdot 571)$ \\
\hline \multirow[t]{2}{*}{ Tax } & & $-5 \cdot 489$ & -4.913 & 2.634 & 2.990 \\
\hline & & $(6.308)$ & $(6.359)$ & $(4 \cdot 530)$ & $(4.167)$ \\
\hline \multirow[t]{2}{*}{ Corruption } & & $-4.774^{*}$ & $-4 \cdot 393$ & -5.297 & -4.121 \\
\hline & & $(2.477)$ & $(6.485)$ & $(3.763)$ & $(5.606)$ \\
\hline \multirow[t]{2}{*}{ Licensing } & & $3 \cdot 586$ & 3.639 & $5 \cdot 399$ & 6.352 \\
\hline & & $(2.989)$ & $(2.865)$ & $(5.090)$ & $(5 \cdot 333)$ \\
\hline \multirow[t]{2}{*}{ Crime } & & 0.088 & -0.330 & $-12.600^{* * *}$ & $-12.430^{* * *}$ \\
\hline & & $(4 \cdot 525)$ & $(4.662)$ & $(3 \cdot 317)$ & $(3.280)$ \\
\hline \multirow[t]{2}{*}{ Log of labour cost per worker (USD) } & & 0.574 & 0.660 & -1.471 & $-2.134^{* *}$ \\
\hline & & $(1.085)$ & $(1.061)$ & $(0.970)$ & $(0.874)$ \\
\hline \multirow[t]{2}{*}{ Log of total employment (-2) } & & 2.481 & 2.593 & -0.566 & -1.794 \\
\hline & & $(2.359)$ & $(2.402)$ & $(1.433)$ & $(1.439)$ \\
\hline \multirow[t]{2}{*}{ Foreign ownership } & & 2.068 & 2.244 & 1.004 & 0.186 \\
\hline & & $(4 \cdot 386)$ & $(4.289)$ & $(6.247)$ & $(5 \cdot 590)$ \\
\hline \multirow[t]{2}{*}{ Log of experience } & & $-4 \cdot 328$ & -3.854 & -2.280 & -3.210 \\
\hline & & $(3 \cdot 423)$ & $(3 \cdot 485)$ & $(2.824)$ & $(2.641)$ \\
\hline \multirow[t]{2}{*}{ Support } & & -1.618 & -1.329 & 8.259 & $8.88 \mathrm{o}$ \\
\hline & & $(7.613)$ & $(7.199)$ & $(7.631)$ & $(6.842)$ \\
\hline \multirow[t]{2}{*}{ Log of age } & & $34 \cdot 336^{* * *}$ & $34.057^{* * *}$ & 11.463 & 10.426 \\
\hline & & $(11.724)$ & $(11.210)$ & $(11.459)$ & $(11.972)$ \\
\hline \multirow[t]{2}{*}{ Log of age squared } & & $-6.150^{* * *}$ & $-6.190^{* * *}$ & $-3 \cdot 356^{*}$ & -3.087 \\
\hline & & $(2.074)$ & $(1.982)$ & $(2.035)$ & $(2.097)$ \\
\hline \multirow[t]{2}{*}{$\mathrm{IPMC}^{*}$ Log of sales (USD) $(-2)$} & & & 0.016 & & $0.046^{* * *}$ \\
\hline & & & (0.015) & & (0.016) \\
\hline \multirow[t]{2}{*}{$\mathrm{IPMC}^{*}$ Corruption } & & & -0.003 & & -0.028 \\
\hline & & & $(0.074)$ & & $(0.121)$ \\
\hline Country fixed effects & No & Yes & Yes & Yes & Yes \\
\hline $\mathrm{N}$ & 508 & 508 & 508 & 461 & 461 \\
\hline Wald chi $^{2}$ & 1203.08 & 1898.98 & 1062.85 & 1043.86 & $1149 \cdot 30$ \\
\hline Prob $>\mathrm{chi}^{2}$ & 0.000 & 0.000 & 0.000 & 0.000 & 0.000 \\
\hline
\end{tabular}

Notes: Robust standard errors in parentheses, ${ }^{*} \mathrm{p}<0.10,{ }^{* *} \mathrm{p}<0.05,{ }^{* * *} \mathrm{p}<0.01$.

Used cmp Stata package for LIML estimation. All standard errors are adjusted for 22 clusters in Region. All standard errors are robust to heteroskedasticity.

All regressions include size of locality dummy. 


\subsection{CONCLUSION}

Firm-level evidence reveals the competitive behaviour of informal enterprises as 'unhealthy', and one of the top three obstacles formal businesses face in sub-Saharan Africa (SSA). The competitive interactions between formal and informal businesses, however, continue to grow with increasing recognition of the 'permanent feature' of the informal economy, particularly in SSA. With limited empirical evidence assessing the economic implications of informal competitive behaviour on formal firms' performance, this chapter fills the gap and contributes to the scant literature by examining the effect of informal product market competition on sales from all innovative products introduced by formal firms in SSA.

The World Bank's Innovation Follow-Up Survey was merged with the Enterprise Survey (ES) for 5 SSA countries. Employing two econometric approaches that localise informal competition in the product market at the first-level of estimation, and controls for self-selection and sample selection biases at the second level of estimation, we have shown that 'local' informal competition matters for the performance of product innovations. That is, informality of the market tends to be detrimental to the performance of product innovations. We, however, found through interactions that product innovations introduced by firms with larger market share tend to perform better with informality of the product market. That is, the main mechanism of increasing sales from product innovations is through the growth in market size. We argued that this indirect mechanism is driven mainly through the level of non-competitive interactions (collaborations and outsourcing of economic activities) between formal and informal businesses. The collaboration and outsourcing of economic activities, we argued, enable registered firms to take strategic advantage of the 'local' market acceptance of informal enterprises to expand market size and perform better with product innovations. As a result, formal firms with less or without any collaborative interaction face intensive competition from informal enterprises, and hence lower sales of product innovations. In other words, formal firms with strategic 'footholds' in the informal economy thrive with new products.

Our findings provide useful evidence that point to informal enterprises as critical actors in the National System of Innovation (NIS) in sub-Saharan Africa. We recommend further research and policy debate on the role of informal enterprises in innovation systems. 


\section{REFERENCES}

African Development Bank (2013). Annual development effectiveness: Towards sustainable growth for Africa. Annual Review. Technical report.

Aghion, P., Bloom, N., Blundell, R., Griffith, R., and Howitt, P. (2005). Competition and Innovation: an Inverted-U Relationship. The Quarterly Journal of Economics, 120(2):701-728.

Aghion, P., Harris, C., Howitt, P., and Vickers, J. (2001). Competition, Imitation and Growth with Step-by-Step Innovation. The Review of Economic Studies, 68(3):467-492.

Aghion, P. and Howitt, P. (1992). A Model of Growth Through Creative Destruction. Econometrica, 60(2):323-351.

Aghion, P., Howitt, P., and Prantl, S. (2013). Revisiting the Relationship between Competition, Patenting, and Innovation. In Advances in Economics and Econometrics, volume 1 of Econometric Society Monographs. Cambridge University Press.

Ali, N. and Najaman, B. (2015). Informal competition and productivity in Sub-Saharan Africa. Paper presented at the 64th Annual Meeting of the French Economic Association (AFSE) June 21-24, Rennes, France.

Amemiya, T. (1985). Advanced Econometrics. Harvard University Press, I edition.

Bargain, O. and Kwenda, P. (2011). Earnings structures, informal employment, and self-employment: New evidence from Brazil, Mexico, and South Africa. Review of Income and Wealth, 57:S10o-S122.

Blundell, R., Griffith, R., and Van Reenen, J. (1999). Market share, market value and innovation in a panel of British manufacturing firms. Review of Economic Studies, 66(3):529-554.

Boldrin, M. and Levine, D. K. (2008). Perfectly competitive innovation. Journal of Monetary Economics, 55(3):435-453.

Bruton, G. D., Ireland, R. D., and Ketchen Jr., D. J. (2012). Toward a Research Agenda on the Informal Economy. Academy of Management Perspectives, 26(3):1-11.

Friesen, J. and Wacker, K. (2013). Do Financially Constrained Firms Suffer from More Intense Competition by the Informal Sector? Firm-Level Evidence from the World Bank Enterprise Surveys. Technical report. 
Gault, F. (2010). Innovation strategies for a global economy: Development, Implementation, Measurement, and Management. Edward Elgar Publishing, IDRC.

Gërxhani, K. (2004). The Informal Sector in Developed and Less Developed Countries: A Literature Survey. Public Choice, 120(3-4):267-300.

Ghana Statistical Service (2012). 2010 Population and housing census (PHC)- Summary report of final results. Technical report, Ghana Statistical Service, Accra.

Gilbert, R. (2006). Looking for Mr. Schumpeter: Where are we in the competitioninnovation debate? In Jaffe, A. B., Lerner, J., and Stern, S., editors, Innovation Policy and the Economy, volume 6, chapter 6, pages 159-215. MIT Press.

Gonzalez, A. S. and Lamanna, F. (2007). Who Fears Competition from Informal Firms ? Evidence from Latin America. World Bank Policy Research Paper, 4316(August).

Guiso, L., Sapienza, P., and Zingales, L. (2004). Does Local Financial Development Matter? The Quarterly Journal of Economics, 119(3):929-969.

Hashmi, A. R. (2013). Competition and Innovation: The Inverted-U Relationship Revisited. The Review of Economics and Statistics, 95(5):1653-1668.

Haug, J. (2014). Critical overview of the (urban) informal economy in Ghana. Technical report, Friedrich-Ebert-Stiftung, Ghana Office, Accra, Ghana.

Heckman, J. (1979). Sample Selection Bias as a Specification Error. Econometrica, 47(1):153-161.

Heintz, J. and Pollin, R. (2008). Targeting Employment Expansion, Economic Growth and Development in Sub-Saharan Africa: Outlines of an Alternative Economic Programme for the Region. Published Studies, Political Economy Research Institute, University of Massachusetts, Amherst, MA.

International Labour Office (ILO). (2013). Youth unemployment rate estimates and projections by region 2007-2017. Technical report, International Labour Office, Geneva.

La Porta, R. and Shleifer, A. (2008). The Unofficial Economy and Economic Development. Brookings Papers on Economic Activity, 39(2 (Fall)):275-363.

Mendi, P. and Costamagna, R. (2017). Managing innovation under competitive pressure from informalproducers. Technological Forecasting and Social Change, 114:192202.

OECD and Eurostat (2005). Oslo Manual. Guidelines for collecting and interpreting innovation data. Organisation for Economic Co-operation and Development, Paris, 3rd edition. 
Peroni, C. and Ferreira, I. S. G. (2011). Competition and Innovation in Luxembourg. Journal of Industry, Competition and Trade, 12(1):93-117.

Roodman, D. (2011). Fitting fully observed recursive mixed-process models with cmp. Stata Journal, 11(2):159-206.

Scherer, F. M. (1967). Market Structure and the Employment of Scientists and Engineers. The American Economic Review, 57(3):524-531.

Schneider, F., Buehn, A., and Montenegro, C. E. (2010). Shadow Economies All Over the World: New Estimates for 162 Countries from 1999 to 2007. Technical report, Rochester, NY.

Schumpeter, J. A. (1942). Capitalism, Socialism and Democracy. Routledge, 6th edition.

van Dijk, M. P. and Sandee, H. (2002). Innovation and Small Enterprise Development in Developing Countries. In van Dijk, M. P. and Sandee, H., editors, Innovation and Small Enterprises in the Third World, chapter One, pages 1-11. Edward Elgar Publishing, Inc., Cheltenham, UK.

Wooldridge, J. M. (2002). Econometric Analysis of Cross Section and Panel Data. The MIT Press. 


\section{APPENDIX}

\section{B.1：DEFINITION OF VARIABLES}

Product innovation: A binary variable taking the value of 1 if the firm has introduced product innovation over the last 3 fiscal years and o if otherwise.

Percentage sales from all product innovations: A continuous variable indicating the percentage of total sales represented by sales from all innovative products or services. It assumes strict value between o-100. Zero implies the firm has not introduced product innovation.

Informal competition: Binary classification that takes the value 1 if the firm considers the competitive practices of the informal sector as a major and a very severe obstacle and the value o otherwise.

Region: A categorical variable showing the twenty-two (22) country sampling regions.

Local informal competition indicator (IPMC): A continuous variable that indicates the local informal product market competition across regions of a country. It ranges between zero (o) and one ( 1 ) where values close to 1 indicate intense informal competition and values close to o indicating less informal competition in the vicinity.

Log of experience: The logarithm of the number of working years of the top manager.

Foreign ownership: A dummy variable that takes value 1 if the firm is foreign owned and o if the firm is owned domestically.

Log of total employment (-2): The logarithm of total number of employees at end of 3 fiscal years ago.

Log of sales (USD) (-2): The logarithm of total sales of output in last three (3) fiscal year converted to United States Dollars using exchange rate in corresponding fiscal year.

Log of labour cost per worker (USD): The logarithm of labour cost per worker in United States Dollars constructed as total cost of labour/total permanent employees+o.5(temporary employees) converted using exchange rate in last fiscal year.

Corruption: A dummy variable that assumes value 1 if the firm identifies corruption as a major constraint and o otherwise. 
Tax: A dummy variable that assumes value 1 if the firm identifies tax rates as a major constraint and o otherwise.

Licensing: A dummy variable that assumes value 1 if the firm identifies the time to it takes to license as a major constraint and o otherwise.

Crime: A dummy variable that assumes value $I$ if the firm identifies crime, theft and disorder as a major constraint and o otherwise.

Lack of access to finance: A dummy variable that assumes value $I$ if the firm identifies access/cost of finance as a major obstacle and o otherwise.

Labour regulations: A dummy variable that assumes value 1 if the firm identifies labour regulations as a major obstacle and o otherwise.

Size of locality: A categorical variable measuring the size of the locality with o if $(<50,000), 1$ if $(\geq 50,000$ and $\leq 250,000), 2$ if $(>250,000$ and $\leq 1$ million $)$ and 3 if large (over 1 million).

Marketing: A dummy variable that assumes value 1 if the firm used services of a marketing firm/ consumer research firm/ advertising firm and o otherwise.

Capital city: A dummy variable that assumes value 1 if the firm is located in the capital city and o otherwise.

Log of age: The log number of years the firm has being operating.

Log of age square: The square of the log of number of years the firm has being operating.

Industry: Sectors according to the group classification of ISIC Revision 3.1: group D, construction sector (group F), services sector (groups $\mathrm{G}$ and $\mathrm{H}$ ), and transport, storage communications sector (group I) and IT (group K sub-sector 72).

Sector: A categorical variable that takes value 1 if the firm is engaged in manufacturing and o if firm is engaged in services. Services combines both retail and other services.

Size of firm: A categorical variable that takes value o if the firm is micro $(<5), 1$ if the firm small $(\geq 5$ and $\leq 19), 2$ if the firm is medium $(\geq 20$ and $\leq 99)$ and 3 if large (100 and over).

Support: A dummy variable that takes value 1 if the firm receives government support and o if otherwise. 
Table B.1: Probit estimation of informal competition as a major constraint

\begin{tabular}{|c|c|}
\hline & Informal competition as a major constraint \\
\hline Foreign ownership & $\begin{array}{l}-0.054^{* *} \\
(0.023)\end{array}$ \\
\hline Lack of access to finance & $\begin{array}{l}0.113^{* * *} \\
(0.028)\end{array}$ \\
\hline Tax & $\begin{array}{c}0.055 \\
(0.059)\end{array}$ \\
\hline Corruption & $\begin{array}{c}0.040 \\
(0.029)\end{array}$ \\
\hline Licensing & $\begin{array}{c}0.081 \\
(0.049)\end{array}$ \\
\hline Crime & $\begin{array}{l}0.114^{* *} \\
(0.046)\end{array}$ \\
\hline Labour regulations & $\begin{array}{l}-0.115 \\
(0.082)\end{array}$ \\
\hline Capital city & $\begin{array}{c}-0.265^{* * *} \\
(0.071)\end{array}$ \\
\hline Log of labour cost per worker (USD) & $\begin{array}{c}0.016 \\
(0.011)\end{array}$ \\
\hline Log of sales (USD) & $\begin{array}{l}-0.023^{* *} \\
(0.010)\end{array}$ \\
\hline Log of Age & $\begin{array}{c}0.041 \\
(0.116)\end{array}$ \\
\hline Log of age squared & $\begin{array}{l}-0.006 \\
(0.026)\end{array}$ \\
\hline Log of experience & $\begin{array}{c}0.004 \\
(0.024)\end{array}$ \\
\hline Size of locality dummy & Yes \\
\hline Size of firm dummy & Yes \\
\hline Industry fixed effects & Yes \\
\hline Region fixed effects & Yes \\
\hline Country fixed effects & Yes \\
\hline $\mathrm{N}$ & 1225 \\
\hline Wald chi ${ }^{2}$ & 711.08 \\
\hline Prob $>c h i^{2}$ & 0.000 \\
\hline Pseudo $R^{2}$ & 0.1326 \\
\hline
\end{tabular}

Notes: Robust standard errors in parentheses, ${ }^{*} \mathrm{p}<0.10,{ }^{* *} \mathrm{p}<0.05,{ }^{* * *} \mathrm{p}<0.01$.

All standard errors are robust to heteroskedasticity. 
Table B.2: Industry ISIC Rev. 3

\begin{tabular}{lcc}
\hline Industry of the firm & Frequency (Data) & Frequency (Sample) \\
\hline Food & 216 & 102 \\
Textiles & 67 & 24 \\
Garments & 121 & 61 \\
Leather & 10 & 7 \\
Wood & 72 & 36 \\
Paper & 7 & 2 \\
Publishing, printing, and Recorded medi & 96 & 51 \\
Chemicals & 67 & 40 \\
Plastics \& rubber & 46 & 28 \\
Non-metallic mineral products & 72 & 42 \\
Basic metals & 25 & 14 \\
Fabricated metal products & 160 & 98 \\
Machinery and equipment & 22 & 13 \\
Electronics (31 \& 32) & 19 & 10 \\
Transport machines (34\&35) & 8 & 3 \\
Furniture & 202 & 97 \\
Construction Section F & 60 & 38 \\
Services of motor vehicles & 110 & 61 \\
Wholesale & 148 & 70 \\
Retail & 488 & 225 \\
Hotel and restaurants: section H & 345 & 160 \\
Transport Section I: (6o-64) & 71 & 35 \\
IT & 24 & 8 \\
\hline Total & 2,456 & 1,225 \\
\hline
\end{tabular}


Table B.3: Computed industry-level informal competition by country

\begin{tabular}{llllll}
\hline & DRC & GH & UGA & TZ & ZAM \\
\hline Industry of the firm & & & & & \\
Food & 59.202 & 59.202 & 59.202 & 59.202 & 59.202 \\
Textiles & - & 62.750 & 62.750 & 62.528 & 62.971 \\
Garments & 51.884 & 52.328 & 51.885 & 52.550 & 51.441 \\
Leather & 98.226 & 100 & - & 94.457 & 96.674 \\
Wood & 55.654 & 55.654 & 55.432 & 55.876 & 55.432 \\
Paper & - & 54.545 & - & - & 53.880 \\
Publishing, printing, and Recorded medi & 20.399 & 24.834 & 17.960 & 22.616 & 14.856 \\
Chemicals & 31.486 & 33.925 & - & 33.259 & 28.160 \\
Plastics \& rubber & 52.106 & 52.550 & 52.106 & 52.772 & 51.663 \\
Nonmetallic mineral products & 44.789 & 45.676 & 44.346 & 45.676 & 43.459 \\
Basic metals & 52.106 & 52.328 & 51.885 & - & 51.441 \\
Fabricated metal products & 31.264 & 33.703 & 30.155 & 33.038 & 27.938 \\
Machinery and equipment & 8.647 & - & - & 11.086 & 0 \\
Electronics (31 \& 32) & - & 83.370 & - & 80.931 & 82.927 \\
Transport machines (34\&35) & - & 32.594 & - & 31.486 & 26.164 \\
Furniture & 56.984 & 56.984 & 56.984 & 56.984 & 56.763 \\
Construction Section F & 21.729 & 25.942 & 19.734 & 23.947 & 16.630 \\
Services of motor vehicles & 31.929 & 34.368 & 30.820 & 33.703 & 28.825 \\
Wholesale & 49.224 & 49.667 & 49.002 & 49.889 & 48.337 \\
Retail & 40.577 & 41.907 & 40.133 & 41.907 & 38.803 \\
Hotel and restaurants: section H & 27.273 & 30.377 & 25.721 & 29.268 & 23.282 \\
Transport Section I: (6o-64) & 41.020 & 42.350 & 40.577 & 42.350 & 39.246 \\
IT & 50.111 & 50.554 & - & 50.776 & 49.446 \\
\hline Note: Means (\%) are based on & & & & &
\end{tabular}

Note: Means (\%) are based on 1, 225 sample data. 
Table B.4: Effect of informal competition on sales from all product innovations

\begin{tabular}{|c|c|c|c|c|}
\hline \multirow[t]{2}{*}{ Estimation method } & \multicolumn{4}{|c|}{ Limited-information maximum likelihood (LIML) } \\
\hline & $(1)$ & (2) & (3) & (4) \\
\hline & \multicolumn{2}{|c|}{$\%$ sales, product innovations } & \multicolumn{2}{|c|}{ Total sales (USD) } \\
\hline Informal competition ${ }^{£}$ & $\begin{array}{l}-4.589^{* * *} \\
(0.756)\end{array}$ & $\begin{array}{l}-4.223^{* * *} \\
(0.671)\end{array}$ & $\begin{array}{c}-53.573^{* * *} \\
(14.233)\end{array}$ & $\begin{array}{c}-50.946^{* * *} \\
(14.320)\end{array}$ \\
\hline Marketing & $\begin{array}{l}5.274 \\
(3.607)\end{array}$ & $\begin{array}{l}5.633 \\
(3.502)\end{array}$ & $\begin{array}{c}18.782 \\
(52.228)\end{array}$ & $\begin{array}{c}22.631 \\
(50.338)\end{array}$ \\
\hline Log of sales (USD) (-2) & $\begin{array}{l}-1.596^{*} \\
(0.817)\end{array}$ & $\begin{array}{l}-0.989 \\
(0.900)\end{array}$ & $\begin{array}{c}7 \cdot 424 \\
(11.382)\end{array}$ & $\begin{array}{c}14.041 \\
(12.398)\end{array}$ \\
\hline Tax & $\begin{array}{l}-2.881 \\
(3.784)\end{array}$ & $\begin{array}{l}-3.605 \\
(3.874)\end{array}$ & $\begin{array}{l}-26.135 \\
(50.367)\end{array}$ & $\begin{array}{l}-33.597 \\
(50.867)\end{array}$ \\
\hline Corruption & $\begin{array}{l}-7.717^{* * *} \\
(2.297)\end{array}$ & $\begin{array}{c}-7.608^{* * *} \\
(2.229)\end{array}$ & $\begin{array}{l}-99.004^{* *} \\
(38.500)\end{array}$ & $\begin{array}{c}-97.639^{* *} \\
(38.067)\end{array}$ \\
\hline Licensing & $\begin{array}{l}5.788^{* * *} \\
(1.891)\end{array}$ & $\begin{array}{c}5.670^{* * *} \\
(1.883)\end{array}$ & $\begin{array}{c}77 \cdot 355^{* * *} \\
(22.080)\end{array}$ & $\begin{array}{c}76.107^{* * *} \\
(22.092)\end{array}$ \\
\hline Crime & $\begin{array}{l}-2.881 \\
(2.775)\end{array}$ & $\begin{array}{l}-2.819 \\
(2.727)\end{array}$ & $\begin{array}{l}-75.957^{*} \\
(43.293)\end{array}$ & $\begin{array}{l}-75.487^{*} \\
(42.497)\end{array}$ \\
\hline Log of labour cost per worker (USD) & $\begin{array}{l}-0.635 \\
(0.715)\end{array}$ & $\begin{array}{l}-0.358 \\
(0.775)\end{array}$ & $\begin{array}{c}2.221 \\
(9.603)\end{array}$ & $\begin{array}{c}0.659 \\
(10.682)\end{array}$ \\
\hline Log of total employment $(-2)$ & $\begin{array}{l}2.176 \\
(1.641)\end{array}$ & $\begin{array}{c}2.314 \\
(1.649)\end{array}$ & $\begin{array}{c}30.992 \\
(22.999)\end{array}$ & $\begin{array}{c}32.420 \\
(22.855)\end{array}$ \\
\hline Foreign ownership & $\begin{array}{l}4.072 \\
(3.978)\end{array}$ & $\begin{array}{c}4.534 \\
(3.924)\end{array}$ & $\begin{array}{c}87.415 \\
(64.023)\end{array}$ & $\begin{array}{c}92.253 \\
(63.631)\end{array}$ \\
\hline Log of experience & $\begin{array}{l}-4.489^{* *} \\
(2.003)\end{array}$ & $\begin{array}{l}-4.112^{* *} \\
(1.861)\end{array}$ & $\begin{array}{c}-54.698^{* * *} \\
(20.429)\end{array}$ & $\begin{array}{c}-50.476^{* * *} \\
(18.205)\end{array}$ \\
\hline Support & $\begin{array}{l}6.400 \\
(5.360)\end{array}$ & $\begin{array}{c}7.079 \\
(5.431)\end{array}$ & $\begin{array}{c}88.578 \\
(63.207)\end{array}$ & $\begin{array}{c}95.851 \\
(63.752)\end{array}$ \\
\hline Log of age & $\begin{array}{l}18.683^{* *} \\
(8.154)\end{array}$ & $\begin{array}{c}17.484^{* *} \\
(8.117)\end{array}$ & $\begin{array}{l}299.577^{* *} \\
(116.312)\end{array}$ & $\begin{array}{l}287.404^{* *} \\
(115.191)\end{array}$ \\
\hline Log of age squared & $\begin{array}{l}-3.369^{* *} \\
(1.467)\end{array}$ & $\begin{array}{c}-3.148^{* *} \\
(1.498)\end{array}$ & $\begin{array}{c}-57.041^{* * *} \\
(21.896)\end{array}$ & $\begin{array}{c}-54.862^{* *} \\
(22.103)\end{array}$ \\
\hline IPMC* Log of sales (USD) $(-2)$ & & $\begin{array}{l}0.011^{* *} \\
(0.005)\end{array}$ & & $\begin{array}{l}0.115 \\
(0.071)\end{array}$ \\
\hline Country fixed effect & Yes & Yes & Yes & Yes \\
\hline $\mathrm{N}$ & 969 & 969 & 969 & 969 \\
\hline Wald chi ${ }^{2}$ & 2730.939 & 3015.11 & 11493.07 & 4466.10 \\
\hline Prob $>\mathrm{chi}^{2}$ & 0.000 & 0.000 & 0.000 & 0.000 \\
\hline
\end{tabular}

Notes: Robust standard errors in parentheses, ${ }^{*} \mathrm{p}<0.10,{ }^{* *} \mathrm{p}<0.05,{ }^{* * *} \mathrm{p}<0.01$.

Used cmp Stata package for LIML estimation. All standard errors are adjusted for 22 clusters in Region. All standard errors are robust to heteroskedasticity.

All regressions include sector, size of locality and 23 industry dummies.

${ }^{£}$ All estimations used 'local' competition indicator (\%) as instrument for informal competition. 



\section{I INTRODUCTION}

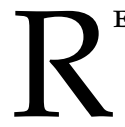

ECENT decades have seen growing interest in the promotion of innovation activities at all levels of governance in Africa. The most recent of these policies is the 'Science, Technology and Innovation Strategy for Africa 2024 (STISA2024)', a short-term strategy adopted by the African Union in 2014. These policies, in general, are laudable in the attempt to promote and foster innovation-led development thinking in Africa. They, however, tend to ignore the 'dualistic' economic structure, and the economic and social significance of 'hidden' innovations in the informal sector. Given the economic significance of the informal economy in Africa, particularly sub-Saharan Africa (SSA), examining informal sector innovations is critical for SSA's economic and social progress (lizuka et al., 2015). While some evidence now exists on innovations in the informal sector in SSA (Bull et al., 2016; Dawson, 1992; Gebreeyesus and Mohnen, 2013; Essegbey and Awuni, 2016; Konte and Ndong, 2012; Kraemer-Mbula, 2016; Fu et al., 2015, among others), both data and empirical evidence remain sparse. This may be due to little policy and research attention.

The objective of this chapter is to present detailed information on a survey conducted in urban Ghana, between May and June 2016, which gathered information on the innovation activities of informal enterprises. The rest of the chapter is organised as follows. The survey methodology is presented in the next section (4.2), followed by descriptive statistics from our informal innovations data set. The last section (4.3) concludes this descriptive chapter. 


\subsubsection{Survey methodology}

Data on informal enterprises and their activities remain scarce in Ghana. The World Bank's Informal Survey provide data on informal enterprises in several developing countries. The Ghana Informal Survey (GIFS) was conducted in 2013, with the aim of providing information on the level of informal activity and reasons for informality. The GIFS, therefore, lacks information on the innovation activities of informal enterprises. Five urban centres, namely Accra, Tema, Takoradi, Kumasi and Tamale were divided into 180 zones from which four interviews were completed per zone. In total, the GIFS contains 729 firms with service and manufacturing firms having equal proportions.

Due to the lack of sampling frame, our survey used zones identified in the GIFS as area-based frame where we randomly selected 17 zones in two urban centers- Accra 9 zones and Tema 8- at first stage. Zones constructed in the GIFS were deemed convenient to use and were also found to offer research design advantages thereby helping to minimise errors. Figure 4.1 presents the heat map of all zones covered, both in Accra and Tema.

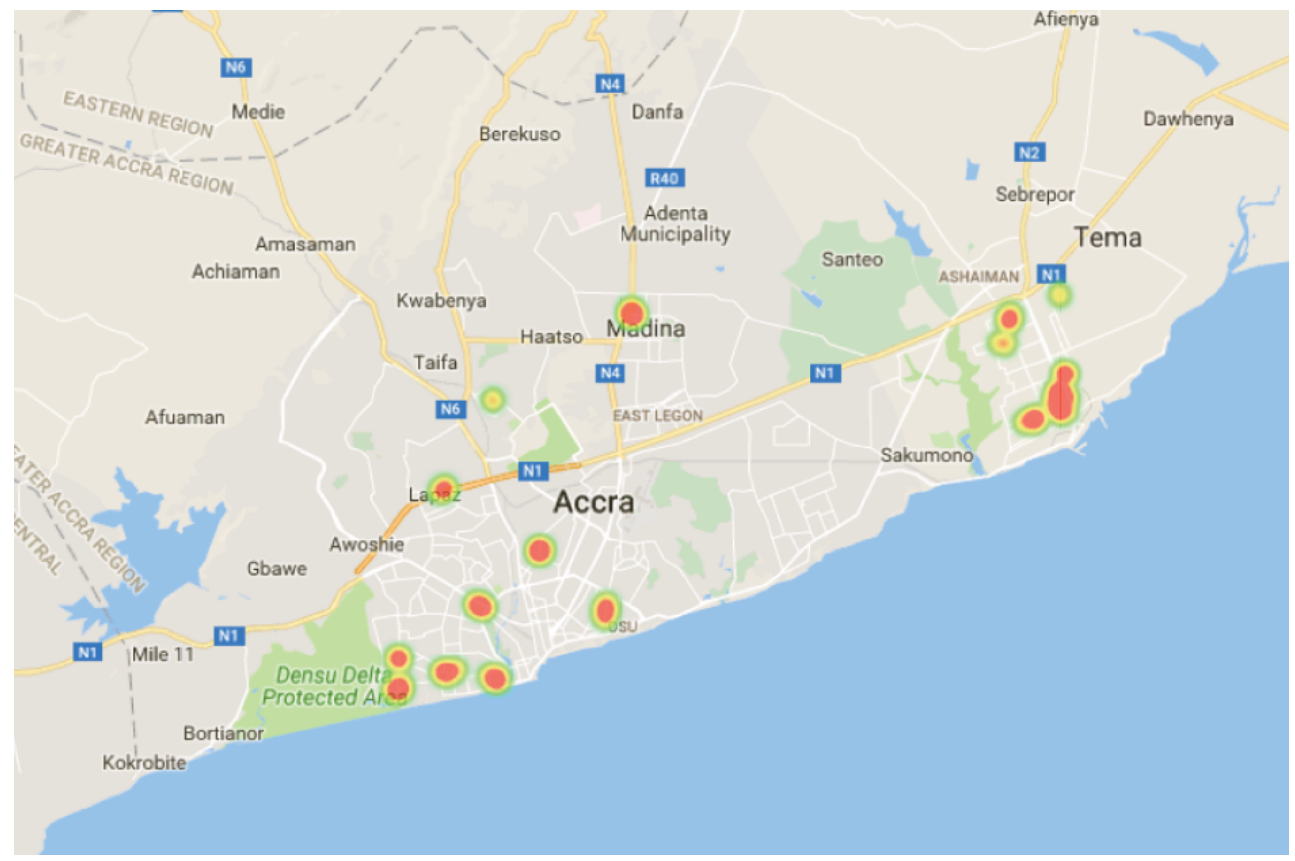

Figure 4.1: Heat map of all zones. 
The second stage of sampling was done by 'canvassing' each selected zone and asking screening questions such as the registration status of the enterprise (see Appendix C.1, Question number SC.o). This involved knocking, introduction and asking of screening questions to identify informal enterprises at the first level. 'Available' owners/care-takers of identified enterprises were then interviewed at the second level. ${ }^{1}$ This approach was found appropriate as it enabled the team to easily differentiate informal enterprises from formal counterparts in locations where such differences were not immediately obvious. This procedure also enabled the team to cover small informal units that are mostly ignored in surveys (International Labour Office (ILO)., 2013). Figure 4.2 presents the aerial maps of some selected zones in Accra.

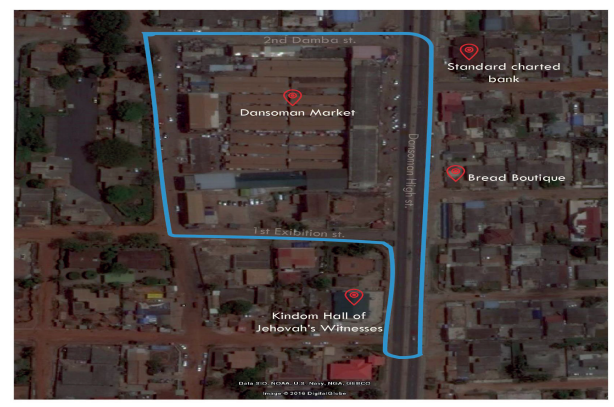

DANSOMAN MARKET ACCRA

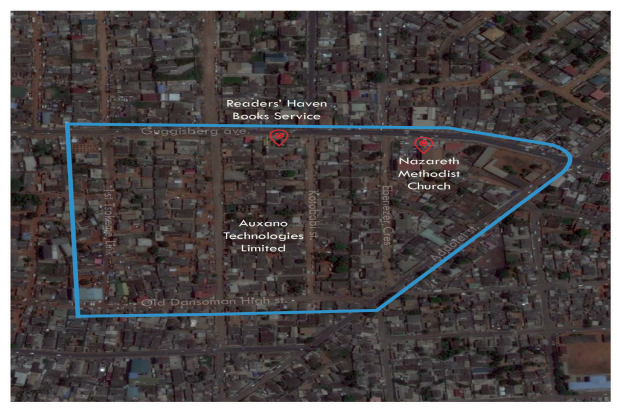

MAMPROB ACCRA

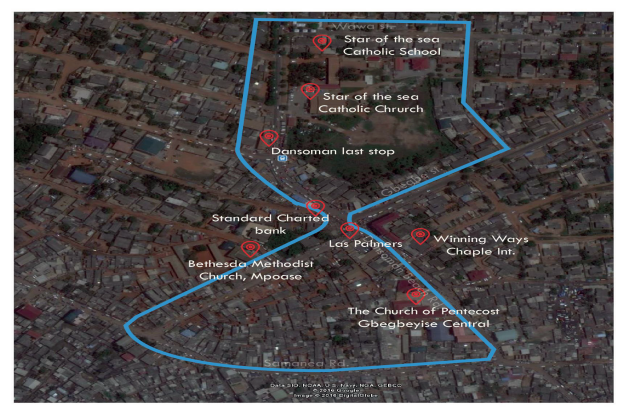

DANSOMAN LAST STOP ACCRA

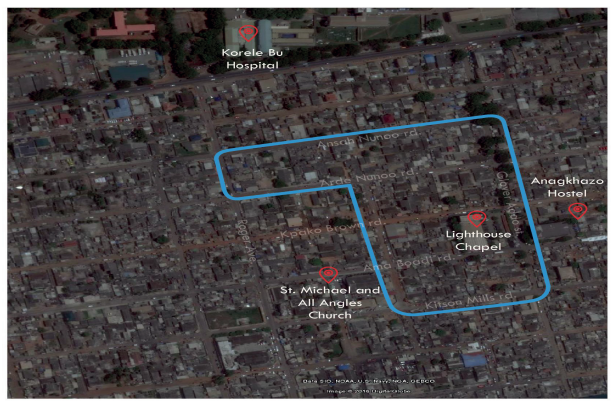

KORLE GONNO ACCRA

Figure 4.2: Aerial maps of selected zones in Accra.

1 As is the case for case studies, owners/care-takers of identified enterprises were not representative of our population from the 'statistical stance'. Our approach used purposive sampling to identify informal enterprises. 
Based on survey recommendations by Charmes et al. (2016), we conducted face-toface interviews with owners/assigned care-takers based on a standard semi-structured questionnaire covering a host of issues such as enterprise registration status, sales, cost, business environment, labour, registration and innovation activities. ${ }^{2}$ The survey instrument was prepared on the guidelines of the Oslo Manual ( $3^{\text {rd }}$ edition), with some questions adapted from similar projects such as the NEPAD's African Science, Technology and Innovation Indicator (ASTII) survey; the World Bank's Ghana Informal Surveys (GIFS); the World Intellectual Property Organization (WIPO) project; the Diffusion of Innovation in Low Income Countries (DILIC) project; Essegbey and Awuni (2016); Fu et al. (2014); and Konte and Ndong (2012). ${ }^{3}$ The interviews were conducted in 4 languages, namely: English, Twi, Ga and Ewe. The objectives of the survey and questions were explained to field assistants in a meeting in order to ensure common understanding of terms and concepts when translating the survey instrument. The survey used modern electronic data collection procedures and software (specifically, SurveyCTO) to collect data. The use of SurveyCTO ensured that the data and other information obtained from the field were of the highest quality in terms of reliability, credibility and utility. This software was chosen because it was cost-effective, secure, efficient and practical for conditions in the field. The survey focused on the innovation activities of enterprises between three-year period, which is 2013-2015.

Table 4.1 presents the list of zones per city and the number of interviews conducted in each sampled zone. The table shows variations in the number of enterprises interviewed in each zone mainly due to differences in the degree of informality of sampled zones as well as the availability of owners/assigned care-takers to be interviewed. Some owners/assigned care-takers, also, bluntly declined to participate based on the suspicion that we were agents of the Government of Ghana. Out of 513 enterprises interviewed in both cities, 317 representing about $62 \%$ of enterprises are located in Accra while 196 representing about $38 \%$ of the enterprises are located in Tema. In terms of the number of interviews conducted in each zone, we found Madina and Community 1 Central Station zones to have the largest number of interviewed enterprises of 47 each across the survey. Tema Driver and Vehicle Licencing Authority (DVLA) zone in Tema, has the lowest number of interviewed enterprises in the data.

2 See Appendix C.1 for survey questionnaire.

3 Some questions were appropriately modified after pretesting in a zone in Kasoa, Central Region. 
Table 4.1: City, zones and sample sizes

\begin{tabular}{llc}
\hline City & Zone & Number of interviews \\
\hline Accra & Dansoman market & 29 \\
& Dansoman last stop & 40 \\
& Mamprobi & 42 \\
& Osu Oxford street & 32 \\
& Accra New Town & 40 \\
& Korle Gonno & 28 \\
& Madina & 47 \\
& Abeka-Lapaz & 21 \\
& Abbosey Okai & 38 \\
\hline Tema & General Hospital & 25 \\
& Tema Senior High School & 34 \\
& Tema DVLA & 4 \\
& Community 1 Police station & 14 \\
& Community 1 Post Office & 42 \\
& Community 1 Central Station & 47 \\
& Rana Motors & $\mathbf{2 0}$ \\
& Community 11 Police station & 10 \\
\hline Total & $\mathbf{1 7}$ & $\mathbf{5 1 3}$ \\
\hline
\end{tabular}




\subsubsection{Descriptive statistics}

This section presents basic descriptive statistics from our informal innovations data on socio-demographic characteristics, innovation, employment activities, the environment of operation and formalisation of enterprises.

\subsubsection{A Enterprise characteristics}

Micro enterprises, defined as enterprises with less than 5 employees (owner included), are the most prevalent in our data. Out of 513 enterprises interviewed, 337 representing about $65.7 \%$ are micro-sized $(<5)$ while about $32.6 \%$ and $1.7 \%$ are small-sized $(5$ $\&<10$ ) and medium-sized(10 \& $<20$ ) respectively (see Table 4.2). Table 4.2 also shows that the majority of interviewed enterprises are owned by men (about $58 \%$ ), with the remaining $42 \%$ owned by women. In terms of sector of activity, our data shows informal enterprises operate mainly in the service sector. The descriptive statistics show about $90 \%$ of enterprises in our data set provide services ${ }^{4}$ while only about $10 \%$ of the enterprises make goods. Decomposing the sectors of economic activity, our data shows $44.8 \%$ of enterprises in the service sector operate by selling food and groceries, indicating the prevalence of retail. This could be due to the low entry cost into these activities. The majority of these enterprises selling food and groceries are made up of local food joints and multi purpose container provision shops selling a variety of products from sachet water, Mcvities short bread cookies, 'joy daddy' bitters to red label whisky. From Table 4.2, we also found that majority of manufacturing informal enterprises make clothes or shoes. Cloth makers are tailoring shops operated by experienced tailors who specialise in sewing dresses, sometimes embodied with local designs. Shoe makers render master shoe repair services, but also produce sandals and 'flip-flops' using locally made machines and raw materials. Family owned businesses are less represented in our data as well with only $21.4 \%$ prevalence.

4 Services refers to retail services and non-retail services (other services) following the Enterprise Survey(ES) of the World Bank. 
Table 4.2: Characteristics of informal enterprises

\begin{tabular}{|c|c|c|}
\hline & Number & Proportion in \% \\
\hline \multicolumn{3}{|l|}{ Size of business } \\
\hline $\operatorname{Micro}(<5)$ & 337 & 65.69 \\
\hline Small $(5 \&<10)$ & 167 & 32.55 \\
\hline Medium (10 \& <20) & 9 & 1.75 \\
\hline \multicolumn{3}{|l|}{ Sex of owner } \\
\hline Male & 300 & 58.48 \\
\hline Female & 213 & 41.52 \\
\hline \multicolumn{3}{|l|}{ Main activity } \\
\hline Making goods (Manufacturing) & 49 & $9 \cdot 55$ \\
\hline Clothes or shoes & 36 & 7.02 \\
\hline Baked food & 3 & 0.58 \\
\hline Handcrafts & 2 & 0.39 \\
\hline Furniture & 3 & 0.58 \\
\hline Metal products & 3 & 0.58 \\
\hline Household items & 2 & 0.39 \\
\hline Selling goods or services (Services) & 464 & 90.45 \\
\hline Food or groceries & 230 & 44.83 \\
\hline Clothes or household items & 63 & 12.28 \\
\hline Computer/phone accessories & 31 & 6.04 \\
\hline Transport services & 1 & 0.19 \\
\hline Hairdressing and barbering & 48 & $9 \cdot 36$ \\
\hline Professional services & 14 & 2.73 \\
\hline Repairing services & 33 & 6.43 \\
\hline Other services (not included above) & 44 & 8.58 \\
\hline \multicolumn{3}{|l|}{ Family business } \\
\hline Yes & 110 & 21.44 \\
\hline No & 403 & 78.56 \\
\hline
\end{tabular}

\subsubsection{B Innovation and innovation activities}

The overarching goal of our survey was to gather information on informal enterprise innovations and innovation activities. As a result, information was collected on various output and input indicators of innovation. While several definitions exist, our sur- 
vey followed broadly statistical definitions in the Oslo Manual (OECD and Eurostat, 2005, Chapter 3). This section presents the descriptive statistics of some innovation indicators obtained from our survey.

Table 4.3 shows the descriptive statistics of informal innovation indicators between 2013-2015. Product innovations are prevalent in informal enterprises with about $73 \%$ of interviewed enterprises introducing at least one product innovation with average percentage sales due to all new products of about $20 \%$ during the period under study. Ideas for new products mainly originate in-house with $88 \%$ of sampled enterprises indicating 'enterprise' as the main source of idea for innovative product. Consumers and clients also serve as an important source of ideas for new products for about $80 \%$ of interviewed enterprises. Ample proportion of enterprises are still undertaking innovation activities with about $39 \%$ of enterprises involved in on-going attempts to introduce new products. Some enterprises, about 30\%, have also indicated abandoning innovation activities. This shows that not all innovation activities actually result in innovation. There are several reasons why an enterprise may introduce product innovation. In our data, we found enterprises innovate largely for 2 main reasons. The first is to increase the range of products offered by the enterprise, and the second is to open or improve market share. Our data shows $93 \%$ of interviewed enterprises introduced product innovation with intention of increasing product range while $92 \%$ innovated in order to improve market share.

Process innovation is low in our sampled informal enterprises. Out of the $5^{13}$ enterprises interviewed, 172 representing about $33.5 \%$ of enterprises introduced at least one of three process innovations. Our data show majority of process innovators, about $90 \%$, introduced innovative methods of manufacturing products or offering services. Ideas for process innovations mainly originate from within informal enterprises with $81 \%$ of enterprises acknowledging the role of in-house ideas in generating knowledge for process innovations. Clients and customers also play an important role in generating process innovations. About $56 \%$ of interviewed enterprises cited consumer$\mathrm{s} /$ clients as the source of idea for their innovative process. Process innovations can be intended for several reasons. From our data, we found informal enterprises introduced process innovation mainly to improve quality of products (about $85 \%$ of interviewed enterprises) followed by intention to improve efficiency of the production and serving offering methods (about $83 \%$ of interviewed enterprises) as well as improving customer delivery methods (about $83 \%$ of interviewed enterprises).

Marketing innovations are widespread in our data. This may be due to the large number of service enterprises in our data. Table 4.3 shows about $88 \%$ of interviewed enterprises introduced at least one type of marketing innovation. Customer loyalty rewards are the most dominant marketing innovation with about $93 \%$ of our sampled enterprises introducing it. Discount schemes and payment schemes are as well prevalent marketing innovations in our data.

Innovation is an output that requires innovation inputs. During our survey, we asked if enterprises have purchased new equipment, machinery, or software to de- 
Table 4.3: Innovation activities of informal enterprises

\begin{tabular}{|c|c|c|}
\hline & Number & Proportion $(\%)$ \\
\hline \multicolumn{3}{|l|}{ Product innovation } \\
\hline Product innovators & 372 & 72.51 \\
\hline$\%$ of sales due to all innovative products (mean) & - & 19.516 \\
\hline \multicolumn{3}{|l|}{ Source of idea for innovative product } \\
\hline Other informal businesses & 183 & 49.19 \\
\hline Formal firms & 38 & 10.22 \\
\hline Consumers/clients & 295 & 79.51 \\
\hline Enterprise itself & 327 & 88.14 \\
\hline \multicolumn{3}{|l|}{ Attempts to develop new products } \\
\hline Suspended before completion & 157 & 30.60 \\
\hline Still ongoing & 201 & 39.18 \\
\hline Increase product range innovators & 346 & 93.01 \\
\hline Open new market or increase market share innovators & 342 & 91.94 \\
\hline \multicolumn{3}{|l|}{ Process innovation } \\
\hline Process innovators & 172 & 33.53 \\
\hline Innovative methods of manaufacturing products & 154 & 89.53 \\
\hline Innovative logistics, delivery or distribution for products & 81 & 47.09 \\
\hline Supporting activity for processes & 72 & 41.86 \\
\hline \multicolumn{3}{|l|}{ Source of idea for innovative process } \\
\hline Other infornal businesses & 45 & 26.16 \\
\hline Formal firms & 22 & 12.87 \\
\hline Consumers/clients & 97 & 56.40 \\
\hline Enterprise itself & 139 & 80.81 \\
\hline Quality-improving innovators & 143 & 83.14 \\
\hline Efficiency-improving innovators (production and offering service) & 146 & 84.88 \\
\hline Efficiency-improving innovators (customer delivery) & 142 & 82.56 \\
\hline \multicolumn{3}{|l|}{ Marketing innovation } \\
\hline Marketing innovators & 452 & 88.11 \\
\hline Packaging & 54 & 12.05 \\
\hline Branding, logo, name or trademark & 98 & 21.83 \\
\hline Products appearance exclusing packaging and branding & 72 & 16.04 \\
\hline Advertising methods & 79 & 17.52 \\
\hline Promotion of the products & 79 & 17.59 \\
\hline Sales channels or sales points & 148 & 32.82 \\
\hline Discount schemes & 341 & 75.61 \\
\hline Pricing strategies, excluding discount schemes & 244 & 53.98 \\
\hline Customer loyalty rewards & 419 & 93.11 \\
\hline Payment schemes & 262 & 58.22 \\
\hline \multicolumn{3}{|l|}{ Purchase new equipment/software for innovation activity } \\
\hline Yes & 76 & 14.84 \\
\hline No & 436 & 85.16 \\
\hline
\end{tabular}


velop or produce innovative products and/or processes (see Appendix C.1, Question E2). Responses from enterprises indicate low levels of input activity with only about $15 \%$ of interviewed enterprises acquiring machinery and softwares for innovation.

To further understand the specific innovations introduced by enterprises, we asked innovative enterprises to describe their main product and process innovations (see Appendix C.1, Questions B.5 and C.4). We identified variations across innovative enterprises with regard to the types of innovations (product and process) developed or adopted.

Table 4.4: Examples of innovations

\begin{tabular}{ll}
\hline Type of innovation & Description of main innovative activity \\
\hline Product & \\
& Making of 'stuffing' chairs \\
& New material to produce 'kente' cloth \\
& Making of new flip-flops for funerals \\
& Using electronic spare parts to produce wall clock \\
& New designs to furniture and clothing \\
& Introduction of a new washing powder \\
& \\
& Vulganising services \\
& Remote and home maintenance \\
& Introduction of home services \\
& Car alarm services \\
& House roofing services \\
& Phone repair services \\
& Mobile money payment methods \\
& \\
& Introduction of new machines- carving machines, steriliser, \\
embroidery machine, bead polishing machine, etc. & Software to keep inventory and records of clients \\
& Delivery methods- new methods to order 'materials', office \\
& delivery, text messages, etc. \\
\hline Process &
\end{tabular}

Table 4.4 presents examples of product and process innovations introduced by enterprises, and it indicates that sampled enterprises mainly introduced new-to-enterprise innovations. For example, a manager of an enterprise selling secondhand car tires indicated to have added vulganising services to his business during the period under 
consideration. An enterprise that produces bathing soaps also indicated to have introduced washing powder entirely based on their existing knowledge and intermediate products. Process innovations such as the introduction of new machines for embroidery, ironing, cutting, and styling hair, were found to be dominant among enterprises engaged in sewing, cutting and dressing of hair. Innovations such as the introduction of office food delivery services (process innovation) and mobile money payment services (product innovation), were found to be most prevalent among enterprises engaged in selling food and groceries.

\subsubsection{Labour}

The economic significance of informal enterprises in SSA cannot be overemphasised. The informal economy dominates economic activity in SSA. In spite of this, data remain largely scarce on the labour market activities of informal enterprises. In our survey, we gathered comprehensive information on the employment activities of our sampled enterprises. Descriptive statistics are shown in Table 4.5. The period under consideration witnessed increase in average total employment in sampled enterprises. Our data show total employment, on the average, increased from 2.44 workers in 2013 to 3.62 workers in 2015 . The type of employment created matters. On the average, permanent employment increased from 1.95 in 2013 to 2.6 in 2015. The data, however, indicate a drop in the share of permanent employment in total employment from about $90 \%$ in 2013 to $80 \%$ in 2015 . Temporary employment also increased on the average in all enterprises from 0.5 in 2013 to about 1.1 in 2015. The period also witnessed an increase in the share of temporary employment in total employment, increasing from $10.23 \%$ in 2013 to $20.25 \%$ in 2015 . While we see an increase in all types of employment, our descriptive statistics suggest decreasing share of permanent employment.

Security of employment is important for the welfare of workers. Our survey sought also to find out the proportion of informal workers covered by social security. The data show only $6.48 \%$ of enterprise owners have social security, with the proportion decreasing drastically to $1.12 \%$ and $0.2 \%$ when we consider permanent and temporary workers, respectively. 
Table 4.5: Employment activities of informal enterprises, 2013-2015

\begin{tabular}{cccccc}
\hline & Mean & Share \% & Std. Dev. & Min & Max \\
\hline Total employment in 2015 & 3.62 & 100 & 2.37 & 1 & 18 \\
Permanent employment & 2.56 & 79.75 & 1.39 & 1 & 11 \\
Temporary employment & 1.06 & 20.25 & 1.50 & 0 & 15 \\
Number of apprentices & .191 & 3.20 & .809 & 0 & 8 \\
Total employment in 2013 & 2.44 & 100 & 1.95 & 1 & 14 \\
Permanent employment & 1.949 & 89.77 & 1.33 & 1 & 13 \\
Temporary employment & .49 & 10.23 & 1.31 & 0 & 12 \\
Social security cover & & & & & \\
Owner & .065 & 6.48 & .246 & 0 & 1 \\
Permanent workers & .012 & 1.12 & .108 & 0 & 1 \\
Temporary workers & .002 & 0.20 & .044 & 0 & 1 \\
\hline
\end{tabular}

\subsubsection{Business environment}

In the course of their daily activities, informal enterprises, like their formal counterparts, face many operational hurdles. These obstacles affect the performance of informal enterpises in diverse ways. While data and empirical evidence remain sparse, our survey gathered information on the degree to which some of these obstacles affect the operations of informal enterprises.

Descriptive statistics reported in Table 4.6 indicate sampled enterprises face 3 main obstacles: competition from informal enterprises, access to land, and lack of electricity and water. 327 enterprises, representing about $64 \%$ of all interviewed enterprises, indicated competition from informal enterprises as an obstacle, with about $75 \%$ of these enterprises indicating competition from informal enterprises serve as a major obstacle to their operations. This may be due to the fact that informal enterprises mostly tend to be: clustered at the same location, similar in size, and tend to compete for the same customers. Access to land remains an obstacle to informal enterprises. About $63 \%$ of enterprises indicated difficulty in accessing land for business. Out of this percentage, about $81 \%$ indicated access to land is, actually, a major hurdle to their operations. Frequent outage of power(electricity), locally known as 'dumsor', and lack of flowing water are persistent problems in Ghana. They affect operations of informal enterprises with 296 enterprises, representing about $58 \%$, indicating the lack of power and water as obstacles to their businesses. Our data show 3 obstacles: crime, theft and disorder, poor public infrastructure, and corruption are the least hurdles to informal enterprise operations. 
Table 4.6: Obstacles to informal enterprise operations

\begin{tabular}{|c|c|c|}
\hline & Number of enterprises & Proportion in \% \\
\hline Competition from formal firms & 215 & 41.91 \\
\hline Minor & 52 & 24.19 \\
\hline Moderate & 6 & 2.79 \\
\hline Major & 157 & 73.02 \\
\hline Acces to finance & 230 & 44.83 \\
\hline Minor & 36 & 15.65 \\
\hline Moderate & 12 & 5.22 \\
\hline Major & 182 & 79.13 \\
\hline Access to land & 324 & 63.16 \\
\hline Minor & 49 & 15.12 \\
\hline Moderate & 12 & $3 \cdot 70$ \\
\hline Major & 263 & 81.17 \\
\hline Corruption & 42 & 8.19 \\
\hline Minor & 21 & 50.00 \\
\hline Moderate & 3 & $7 \cdot 14$ \\
\hline Major & 18 & 42.86 \\
\hline Crime, theft, disorder & 197 & 38.40 \\
\hline Minor & 88 & 44.67 \\
\hline Moderate & 17 & 8.63 \\
\hline Major & 92 & 46.70 \\
\hline Poor public insfrastructure & 156 & 30.41 \\
\hline Minor & 70 & 44.87 \\
\hline Moderate & 17 & 10.90 \\
\hline Major & 69 & 44.23 \\
\hline Low demand for products & 256 & $49 \cdot 90$ \\
\hline Minor & 52 & 20.31 \\
\hline Moderate & 12 & 4.69 \\
\hline Major & 192 & 75.00 \\
\hline Lack of electricity and water & 296 & $57 \cdot 70$ \\
\hline Minor & 54 & 18.24 \\
\hline Moderate & 12 & 4.05 \\
\hline Major & 230 & $77 \cdot 71$ \\
\hline Competition from other informal enterprises & 327 & 63.74 \\
\hline Minor & 73 & 22.32 \\
\hline Moderate & 8 & 2.45 \\
\hline Major & 246 & 75.23 \\
\hline
\end{tabular}




\subsubsection{E Registration}

How to formalise informal enterprises in developing countries remain a development question. During our survey, we asked informal enterprises if they would want to formalise, and reasons for their informality (see Appendix C.1, Section I). Table 4.7 shows 347 enterprises, making up about $68 \%$, indicated they would like to be registered. Asking why they are not registered, we found: long registration procedure, lack of information about registration, registration fees, taxes, and lack of benefits in registration as some of the main reasons for informality. Of particular interest here, is the obvious disagreement between the proportion of enterprises who would like to register (about 68\%) and the proportion who indicated there are no benefits to registration (about $60 \%$ ). This may be as a result of response bias due to the perception that informality is undesirable.

Table 4.7: Reasons for informality

\begin{tabular}{lcc}
\hline & Number of enterprises & Proportion in \% \\
\hline Register business (formalise) & 347 & 68.31 \\
Reasons for informality & & \\
Lack of registration info & 362 & 72.26 \\
Registration procedure (time) & 363 & 73.19 \\
Rgistration fees & 355 & 71.00 \\
Taxes & 333 & 66.60 \\
Inspections & 289 & 57.57 \\
Bribes & 175 & 34.93 \\
No benefit to enterprise & 302 & 60.28 \\
\hline
\end{tabular}

\section{$4 \cdot 3$ CONCLUSION}

Our informal innovations survey in Ghana aimed at providing insights into the innovation activities of informal enterprises, and also to examine research and policy ideas on how to enhance these innovation activities. This chapter presents basic descriptive statistics from the survey. Randomly selecting 17 zones and canvassing each zone for informal enterprises, we were able to interview 513 enterprises. Our descriptive statistics show our sampled enterprises are mostly micro $(<5)$ in size. Product innovations are found to be pervasive in informal enterprises, with in-house ideas as the main source of innovative products. In terms of employment, we found only few 
informal workers have social security with the share of temporary employment in total employment increasing between 2013-2015. Enterprises are found to be affected by 3 main obstacles: competition from informal enterprises, access to land, and lack of electricity and water. While we found enterprises to have the desire to formalise: long registration procedure, lack of information about registration fees, taxes, and lack of opportunities after registration, remain some of the main reasons for informality. Policy efforts need to carefully consider and address these issues. 


\section{REFERENCES}

Bull, C., Daniels, S., Kinyanjui, M., and Hazeltine, B. (2016). A Study of the Informal Metalworking Sector in Nairobi. In Kraemer-Mbula, E. and Wunsch-Vincent, S., editors, The Informal Economy in Developing Nations: Hidden Engine of Innovation?, pages 100-145. Cambridge University Press, Cambridge.

Charmes, J., Gault, F., and Wunsch-Vincent, S. (2016). Formulating an Agenda for the Measurement of Innovation in the Informal Economy. In Kraemer-Mbula, E. and Wunsch-Vincent, S., editors, The Informal Economy in Developing Nations: Hidden Engine of Innovation?, pages 336-370. Cambridge University Press, Cambridge.

Dawson, J. (1992). The Relevance of the Flexible Specialisation Paradigm for SmallScale Industrial Restructuring in Ghana. IDS Bulletin, 23(3):34-38.

Essegbey, G. O. and Awuni, S. (2016). Herbal Medicine in the Informal Sector of Ghana. In Kraemer-Mbula, E. and Wunsch-Vincent, S., editors, The Informal Economy in Developing Nations: Hidden Engine of Innovation?, pages 194-231. Cambridge University Press, Cambridge.

Fu, X., Mohnen, P., and Zanello, G. (2015). Innovation, informality, and firms' growth in low-income countries. TMD working paper 72. TMCD, Oxford, UK.

Gebreeyesus, M. and Mohnen, P. (2013). Innovation Performance and Embeddedness in Networks: Evidence from the Ethiopian Footwear Cluster. World Development, 41:302-316.

Iizuka, M., Mawako, P., and Gault, F. (2015). Innovation for Development in Southern and Eastern Africa: Challenges for Promoting ST\&I Policy. UNU-MERIT Policy Brief 1 .

International Labour Office (ILO). (2013). Youth unemployment rate estimates and projections by region 2007-2017. Technical report, International Labour Office, Geneva.

Konte, A. and Ndong, M. (2012). The informal ICT sector and innovation processes in Senegal. African Journal of Science, Technology, Innovation and Development, 4(3):61-97.

Kraemer-Mbula, E. (2016). Informal Manufacturing of Home and Personal Care Products in South Africa. In Kraemer-Mbula, E. and Wunsch-Vincent, S., editors, The Informal Economy in Developing Nations: Hidden Engine of Innovation?, pages 146-193. Cambridge University Press, Cambridge. 
OECD and Eurostat (2005). Oslo Manual. Guidelines for collecting and interpreting innovation data. Organisation for Economic Co-operation and Development, Paris, 3rd edition. 


\section{Brief description of study}

Recent studies find innovation to be pervasive in the informal economy. This project's overarching goal is to understand the types of innovations informal firms use and adapt to answer customers changing needs and demands. The project also aims to provide evidence on the role of networks and apprenticeship in learning, adopting and adapting innovations in the informal sector and the labour market implications.

This survey aims to collect valuable information on these variables and the information collected from this survey will be used strictly for academic purposes to understand the current situation for improving policy. The study guarantees absolute anonymity of your business and personal details.

Your kind attention and cooperation is much appreciated.

If you have further queries, please contact Elvis Korku Avenyo (avenyo@merit.unu.edu). 
QUESTIONNAIRE NUMBER

\section{A. CONTROL AND SCREENING INFORMATION}

CONTROL INFORMATION
\begin{tabular}{|l||l|}
\hline A.0 City & 1 \\
\hline Accra & 2 \\
\hline Tema
\end{tabular}

\section{A.1 Zone}

Zone of business

A.2 Language

\begin{tabular}{|l||l||}
\hline English & 1 \\
\hline Twi & 2 \\
\hline
\end{tabular}

A.3 Interviewer code

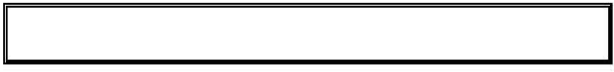

A. 4 Size of business

\begin{tabular}{|l||l|}
\hline Micro $<5$ & 1 \\
\hline Small $>=5 \&<10$ & 2 \\
\hline Medium $>=11 \&<20$ & 3 \\
\hline Large $>21$ & 4 \\
\hline
\end{tabular}

A.5 Time interview begins

\begin{tabular}{|l|l||l|l|l|}
\hline Day & Month & Hour & Minutes \\
\hline & & & & \\
& & & & \\
\hline
\end{tabular}

A.6 Year business began operations

A.7 Sex of the owner

\begin{tabular}{|l||l|}
\hline Year & \\
\hline \hline Don't know & -9 \\
\hline
\end{tabular}

\begin{tabular}{||l|l|}
\hline Male & 1 \\
\hline Female & 2 \\
\hline
\end{tabular}

A.8 Is this business a (part of a) family business? A.9 What is your position?

\begin{tabular}{|l||l|}
\hline No & 0 \\
\hline Yes & 1 \\
\hline
\end{tabular}

\begin{tabular}{|l|l|}
\hline \hline Position & \\
\hline Don't know & \\
\hline
\end{tabular}

\section{SC. SCREENING INFORMATION}

SC.0 Is this business registered with the Registrar's General Dept.?

\begin{tabular}{|l||l|}
\hline No & 0 \\
\hline Yes & 1 \\
\hline
\end{tabular}

Terminate Interview 
PLEASE CODE THE DESCRIPTION IN SC.1.

\begin{tabular}{|c|c|c|}
\hline \multirow[t]{9}{*}{ Making goods (Manufacturing) } & Manufacturing of clothes or shoes & 1 \\
\hline & Manufacturing of baked food (Baker) & 2 \\
\hline & $\begin{array}{l}\text { Manufacturing of sugar, oil, dry fruits and other } \\
\text { processed foods }\end{array}$ & 3 \\
\hline & Manufacturing of handerafts & 4 \\
\hline & Manufacturing of furniture & 5 \\
\hline & Manufacturing of metal products & 6 \\
\hline & Manufacturing of household items & 7 \\
\hline & Manufacturing of tools and instruments & 8 \\
\hline & Other manufacturing (not included above) & 9 \\
\hline \multirow[t]{11}{*}{ Selling goods or services (services) } & Selling of food or groceries & 11 \\
\hline & Selling of clothes or household items & 12 \\
\hline & Selling of other goods & 13 \\
\hline & Selling of business/computer/phone services & 14 \\
\hline & Transport Services & 15 \\
\hline & Cleaning and washing services & 16 \\
\hline & Hairdressers and barber shops & 17 \\
\hline & Professional services & 18 \\
\hline & Repairing services & 19 \\
\hline & Construction & 20 \\
\hline & Other services (not included above) & 21 \\
\hline
\end{tabular}




\section{B. PRODUCT INNOVATION}

I would like to start by asking you some questions about any new or significantly improved product or service introduced by this establishment, where "new" means new to the establishment and not necessarily new to the market. The next questions will refer to this new or significantly improved product or service as an "innovative" product or service.

B.1 During the last three years (2013-2015), has this business introduced new or significantly improved products or services?

\begin{tabular}{|l|l|}
\hline No & 0 \\
\hline Yes & 1 \\
\hline
\end{tabular}

B.2 From last three fiscal years, how many innovative products or services did this establishment introduce?

\begin{tabular}{|l|l|}
\hline Number & \\
\hline Don't know & -9 \\
\hline
\end{tabular}

B.3 In which year did this establishment introduce the innovative product or service?

\begin{tabular}{|l|l|}
\hline Year & \\
\hline Don't know & -9 \\
\hline
\end{tabular}

B.4 In fiscal year 2015, what percentage of this establishment's total sales was represented by sales from all innovative products or services introduced from fiscal year 2013 thru 2015?

\begin{tabular}{|l|l|}
\multicolumn{1}{c}{ GHC } \\
\hline Amount & \\
\hline Don't know & -9 \\
\hline
\end{tabular}

B.5 Please describe in detail the main innovative product or service that this establishment introduced.

B.6 How do the innovative product or service compared with all other products and services already produced in this establishment?

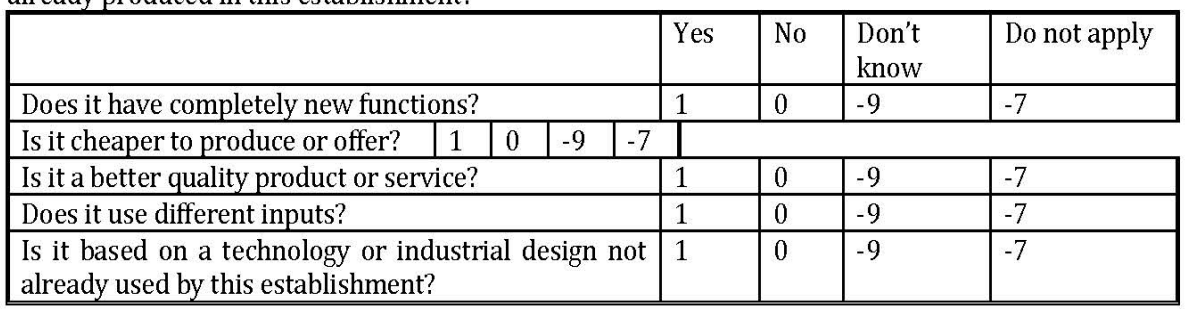


B.7 Do any of the following describe why this establishment introduced this main innovative product or service?

\begin{tabular}{|l|l|l|l|}
\hline & Yes & No & Don't know \\
\hline To replace a product or service offered by this establishment & 1 & 0 & -9 \\
\hline $\begin{array}{l}\text { To extend the range of products or service offered by this } \\
\text { establishment }\end{array}$ & 1 & 0 & -9 \\
\hline To open up new markets or increase market share & 1 & 0 & -9 \\
\hline To decrease the cost of production or offering the service & 1 & 0 & -9 \\
\hline $\begin{array}{l}\text { To deal with a decrease in the demand for other products or } \\
\text { service }\end{array}$ & 1 & 0 & -9 \\
\hline To offer products or service already offered by competitors & 1 & 0 & -9 \\
\hline
\end{tabular}

B.8 How did this establishment develop the idea for the innovative product or service?

\begin{tabular}{|l|l|}
\hline By reproducing/adapting a product or service already sold by another informal business & 1 \\
\hline By reproducing/adapting a product or service already sold by a formal firm & 2 \\
\hline From consumers/clients & 3 \\
\hline This establishment originated this innovative product or service & 4 \\
\hline
\end{tabular}

B.9 From last three fiscal years, did this establishment attempt to develop an innovative product or service that was:

\begin{tabular}{|l|l|l|l|}
\hline & Yes & No & Don't know \\
\hline Abandoned or suspended before completion & 1 & 0 & -9 \\
\hline Still ongoing at the end of fiscal year & 1 & 0 & -9 \\
\hline
\end{tabular}

\section{PROCESS INNOVATION}

I would now like to ask you some questions related to any new or significantly improved process introduced by this establishment. The next questions will refer to any new or significantly improved process as an "innovative" process.

C.1 From fiscal year 2013 thru 2015, did this establishment introduce any innovative methods of manufacturing products or offering services?

\begin{tabular}{|l|l|}
\hline No & 0 \\
\hline Yes & 1 \\
\hline
\end{tabular}

C.2 From fiscal year 2013 thru 2015, did this establishment introduce any innovative logistics, delivery, or distribution methods for inputs, products, or services?

\begin{tabular}{|l|l|}
\hline No & 0 \\
\hline Yes & 1 \\
\hline
\end{tabular}

C.3 From fiscal year 2013 thru 2015, did this establishment introduce any innovative supporting activity for processes, such as maintenance systems or operations for purchasing, accounting, or computing?

\begin{tabular}{|l|l|}
\hline No & 0 \\
\hline Yes & 1 \\
\hline
\end{tabular}


C.4 Please describe in detail this establishment's main innovative process.

C.5 Do any of the following describe why this establishment introduced the most important innovative process?

\begin{tabular}{|l|l|l|l|}
\hline & Yes & No & Don't know \\
\hline To increase the quality of products or services & 1 & 0 & -9 \\
\hline To increase the total production or amount of services offered & 1 & 0 & -9 \\
\hline To increase the flexibility of production or offering service & 1 & 0 & -9 \\
\hline To increase the speed of production or offering service & 1 & 0 & -9 \\
\hline To increase the speed of delivery to the customer & 1 & 0 & -9 \\
\hline To reduce waste or errors (defect rate or rejection rate) & 1 & 0 & -9 \\
\hline
\end{tabular}

C.6 How did this establishment develop the idea for the innovative process?

\begin{tabular}{|l|l|}
\hline By reproducing/adapting a product or service already sold by another informal business & 1 \\
\hline By reproducing/adapting a product or service already sold by a formal firm & 2 \\
\hline From consumers/clients & 3 \\
\hline This establishment originated this innovative product or service & 4 \\
\hline
\end{tabular}

C.7 In fiscal year 2015, what percentage of this establishment's total sales was represented by sales from all process innovations introduced from fiscal year 2013 thru 2015?

\begin{tabular}{|l|l|}
\multicolumn{1}{c}{ GHC } \\
\hline Amount & \\
\hline Don't know & -9 \\
\hline
\end{tabular}

\section{MARKETING INNOVATION}

D.1 From fiscal year 2013 thru 2015, did this establishment introduce or significantly change any of the following?

\begin{tabular}{|l|l|l|l|l|}
\hline & Yes & No & Don't know & Do not apply \\
\hline Packaging & 1 & 0 & -9 & -7 \\
\hline Branding, logo, name, or trademark & 1 & 0 & -9 & -7 \\
\hline Products' appearance, excluding packaging or branding & 1 & 0 & -9 & -7 \\
\hline Advertising methods & 1 & 0 & -9 & -7 \\
\hline Promotion of the product or service & 1 & 0 & -9 & -7 \\
\hline Sales channels or sales points & 1 & 0 & -9 & -7 \\
\hline Discount schemes & 1 & 0 & -9 & -7 \\
\hline Pricing strategies, excluding discount schemes & 1 & 0 & -9 & -7 \\
\hline Customer loyalty rewards & 1 & 0 & -9 & -7 \\
\hline Payment schemes & 1 & 0 & -9 & -7 \\
\hline \hline
\end{tabular}

D.2 From fiscal year 2013 thru 2015, did this establishment use the services of a marketing firm, consumer research firm, or advertising firm? 


\begin{tabular}{|l|l|}
\hline No & 0 \\
\hline Yes & 1 \\
\hline Don't know & -9 \\
\hline
\end{tabular}

D.3 In fiscal year 2015, what percentage of this establishment's total sales was represented by sales from all marketing innovations introduced from fiscal year 2013 thru 2015?

\begin{tabular}{|l|l|}
\multicolumn{1}{c}{} & \multicolumn{1}{c}{ GHC } \\
\hline Amount & \\
\hline Don't know & -9 \\
\hline
\end{tabular}

\section{E. INNOVATION ACTIVITIES}

E.1 Did this establishment provide formal training to any of its employees specifically for the development and/or introduction of innovative products or services and processes?

\begin{tabular}{|l|l|}
\hline No & 0 \\
\hline Yes & 1 \\
\hline Don't know & -9 \\
\hline
\end{tabular}

E.2 From fiscal year 2013 thru 2015, did this establishment purchase new equipment, machinery, or software to develop or produce any innovative products or services and processes?

\begin{tabular}{|l|l|}
\hline No & 0 \\
\hline Yes & 1 \\
\hline Don't know & -9 \\
\hline
\end{tabular}

E.3 How much did this establishment spend in total on the purchase of that new equipment, machinery, or software last fiscal year?

\begin{tabular}{|l|l|}
\multicolumn{1}{r}{} & GHC \\
\hline Amount & \\
\hline Don't know & -9 \\
\hline
\end{tabular}

E.4 Do you think registering your business would affect your innovative activities?

\begin{tabular}{|l|l|}
\hline No & 0 \\
\hline Yes & 1 \\
\hline Don't know & -9 \\
\hline
\end{tabular}

E.5 During the last three years, did this establishment give employees/apprentice some time to develop or try out a new approach or new idea about products or services, business process, business management, or marketing?

\begin{tabular}{|l|l|}
\hline No & 0 \\
\hline Yes & 1 \\
\hline Don't know & -9 \\
\hline
\end{tabular}




\section{F. LABOUR}

F.1 How many individuals worked in this business when it began operations?

\begin{tabular}{|l|l|}
\hline Number & \\
\hline Don't know & -9 \\
\hline
\end{tabular}

F.2 How many permanent, full-time individuals worked in this establishment last year?

\begin{tabular}{|l|l|}
\hline Number & \\
\hline Don't know & -9 \\
\hline
\end{tabular}

F.3 Full-time seasonal or temporary individuals who worked in this establishment last year?

\begin{tabular}{|l|l|}
\hline Number & \\
\hline Don't know & -9 \\
\hline
\end{tabular}

F.4 How many individuals worked in this business three fiscal years ago, i.e. 2013?

Number Don't know

\begin{tabular}{|l|l|l|}
\hline Permanent, full-time individuals & -9 \\
\hline Seasonal, or temporary individuals & & -9 \\
\hline
\end{tabular}

F.5 How many apprentice(s) did you have in your enterprise?

\begin{tabular}{|l|l|}
\hline 2015 & Number \\
\hline 2015 & \\
\hline
\end{tabular}

F.6 Have any of your apprentices' been a source of your innovative idea/ideas in the last three fiscal years?

\begin{tabular}{|l|c|}
\hline No & 0 \\
\hline Yes & 1 \\
\hline Do not apply & -7 \\
\hline
\end{tabular}

F.7 Do you pay social security for yourself and any of the following categories of employees?

\begin{tabular}{|l|l|l|l|l||}
\hline & Yes & No & Don't know & Do not apply \\
\hline Yourself & 1 & 0 & -9 & -7 \\
\hline Permanent, full-time workers & 1 & 0 & -9 & -7 \\
\hline Seasonal, or temporary workers & 1 & 0 & -9 & -7 \\
\hline Apprentice & 1 & 0 & -9 & -7 \\
\hline
\end{tabular}

\section{G. SALES}

G.1 What is the business's sale in a regular month, that is, a month that is neither the busiest nor 
the slowest of the year?

\begin{tabular}{|l|l|}
\hline Amount & \\
\hline Don't know & -9 \\
\hline
\end{tabular}

G.2 Could you please estimate the business's sales in the slowest month of the year?

\begin{tabular}{|l|l|}
\hline \multicolumn{1}{c}{ GHC } \\
\hline Amount & \\
\hline Don't know & -9 \\
\hline
\end{tabular}

G.3 Could you please estimate the business's sales in the busiest month of the year?

\begin{tabular}{|l|l|}
\multicolumn{1}{c}{ GHC } \\
\hline Amount & \\
\hline Don't know & -9 \\
\hline
\end{tabular}

G.4 For last month, please provide the following information about this business:

\begin{tabular}{|l|l|l|}
\hline & Amount GHC & Don't know \\
\hline a. Total sales & -9 \\
\hline b. Total cost of labor & & -9 \\
\hline c. Cost of raw materials/intermediate goods used in production & & -9 \\
\hline
\end{tabular}

G.5 For last year, please provide the following information about this business:

\begin{tabular}{|l|l|l|}
\hline & Amount GHC & Don't know \\
\hline a. Total sales & & -9 \\
\hline b. Total cost of labor & & -9 \\
\hline c. Cost of raw materials and intermediate goods used in production & & -9 \\
\hline
\end{tabular}

G.6 For 2013, please provide the following information about this business:

\begin{tabular}{|l|l|l|}
\hline & Amount GHC & Don't know \\
\hline a. Total sales & & -9 \\
\hline b. Total cost of labor & & -9 \\
\hline c. Cost of raw materials and intermediate goods used in production & & -9 \\
\hline
\end{tabular}

\section{H. BUSINESS ENVIRONMENT}

H. 1 Does the following elements of the business environment, if any, currently represent an obstacle faced by this business.
a. Competition from formal firms
b. Limited access to finance
c. Restricted access to land

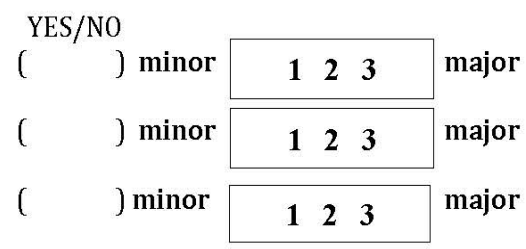


d. Corruption

e. Crime, theft and disorder

f. Poor public infrastructure

g. Difficult business registration procedures

h. Limited demand for product or services

i. Lack of electricity and water

j. Competition from other informal businesses (

\begin{tabular}{|c|c|}
\hline ) minor & $\begin{array}{lll}1 & 2 & 3\end{array}$ \\
\hline ) minor & 123 \\
\hline
\end{tabular}

major

major

major

) minor $12 \quad 2$

) minor 1123

major

) minor 123

major

) minor 123

major

J minor 123

H.2 Did your business have any relationship with any firm in the formal sector over the last three years?

\begin{tabular}{|l|l|}
\hline No & 0 \\
\hline Yes & 1 \\
\hline
\end{tabular}

H.3 If yes from H.2, What was the nature of your business' relationship with formal firms?

\begin{tabular}{|l|l|l|c|}
\multicolumn{2}{c}{ Yes } & No & Don't know \\
\hline Compete for same customers & 1 & 0 & -9 \\
\hline Collaborate - produce, sell, buy & 1 & 0 & -9 \\
\hline
\end{tabular}

H.4 If yes from H.1a/j, what strategies do you use to compete?

\section{REGISTRATION}

I.1 Would you like for your business to be registered?

\begin{tabular}{|l|c|}
\hline No & 0 \\
\hline Yes & 1 \\
\hline Do not apply & -7 \\
\hline
\end{tabular}

I.2 Are any of the following the reason you are not registered?

\begin{tabular}{|l|c|c|c|}
\hline & Yes & No & Don't know \\
\hline Getting information on what you need to do to register is difficult & 1 & 0 & -9 \\
\hline Time to complete registration procedures & 1 & 0 & -9 \\
\hline Fees to complete registration procedures & 1 & 0 & -9 \\
\hline Taxes on registered businesses & 1 & 0 & -9 \\
\hline
\end{tabular}




\begin{tabular}{|l|l|l|l|}
\hline Potential inspections and meetings with government officials & 1 & 0 & -9 \\
\hline Bribes that registered businesses need to pay & 1 & 0 & -9 \\
\hline There is no benefit for my business being registered & 1 & 0 & -9 \\
\hline Other & 1 & 0 & -9 \\
\hline
\end{tabular}

END OF THE INTERVIEW

THANK YOU VERY MUCH FOR YOUR COOPERATION.

A.10 Time interview ends

\begin{tabular}{|l|l|l|l|l|}
\hline Day & Month & Year & Hour & Minutes \\
\hline & & & & \\
\hline
\end{tabular}

QUESTIIONS FOR INTERVIEWER

A.11 It is my perception that the questions were answered:

\begin{tabular}{|l|l|}
\hline Truthfully & 1 \\
\hline Somewhat truthfully & 2 \\
\hline Not truthfully & 3 \\
\hline
\end{tabular}

A.12 Interviewer's general comments: 


\section{LEARNING AND PRODUCT INNOVATIONS PERFORMANCE IN GHANA: EMPIRICAL STUDY OF INFORMAL ENTERPRISES}

\subsection{INTRODUCTION}

I NFORMAL enterprises in sub-Saharan Africa (SSA) learn how to organise, and produce goods and services through cumulative and diverse processes just like firms elsewhere. These deliberate learning processes are found in the literature to generate knowledge key for firm capability development (Bell and Albu, 1999; Lall, 2000; Malerba, 1992) as well as critical in shaping and directing the technological and productive paths of firms (Oyelaran-Oyeyinka and Lal, 2006; Malerba, 1992). While learning, as a result, is central for innovation within firms, empirical evidence examining the effect of learning processes on the innovation activities of informal enterprises in SSA remains scant and anecdotal. This chapter adds to this literature by providing micro-level evidence. The chapter differs by specifically analysing the effect of apprenticeship, and goes beyond the formal-informal dichotomy to examine formalinformal interactions (formal interaction hereafter) on the innovation performance of informal enterprises in Ghana. ${ }^{1}$

Informality in developing countries remains large, paramount and a success (Hart, 2006). The informal economy is significant and dominates economic activities in SSA, where the informal sector is estimated to employ about $60 \%-80 \%$ of workers (Benjamin and Mbaye, 2015). As a result, the informal economy and the activities of informal enterprises in developing countries have seen increased academic and policy interest, in recent years. While evidence remains sparse, recent case studies analysing the innovation activities of informal enterprises reveal the pervasiveness of innovations in SSA. These studies find innovations in informal enterprises to be largely incremental, defined by local demand and knowledge acquired through 'alternative' learning processes to satisfy local needs. ${ }^{2}$

1 Gebreeyesus and Mohnen (2013) studied the effect of network size in an Ethiopian Footwear Cluster on the intensity of innovations while Kawooya (2014) analysed the effects of formal-informal interactions on the innovative activities of formal enterprises in Uganda.

2 See Bull et al. (2016); Essegbey and Awuni (2016); Fu et al. (2014); Gebreeyesus and Mohnen (2013); Kraemer-Mbula (2016); Dawson (1992); Konte and Ndong (2012); Mcdade and Malecki (1997). 
Research and Development (R\&D) is a crucial technological learning process for innovation (see for example Cohen and Levinthal (1989)). R\&D is not, however, the only learning process that generates knowledge essential for innovation in small enterprises (Legros and Galia, 2011; Oyelaran-Oyeyinka and Lal, 2006; Malerba, 1992). Informal enterprises in SSA are not engaged in $R \& D$, and are mainly involved in incremental innovations which cannot be appropriately accounted for by measures based on R\&D, for instance. ${ }^{3}$ Informal enterprises are, however, evidenced to learn to innovate through 'alternative' learning processes such as apprenticeship (Kawooya, 2014, p.66).

Apprenticeship in developing countries remains a major source and a medium for the transfer of both codified and tacit knowledge for use in the local context (OyelaranOyeyinka and Lal, 2006). In Africa, apprenticeship is a 'living reality' (Bas, 1989), and remains popular in the informal economy where it plays a key role as an institution of learning and training for mainly small enterprises (Bas, 1989; Frazer, 2006; Velenchik, 1995). Despite its critical role, apprenticeship remains largely neglected in the economic literature in SSA. ${ }^{4}$ The existing sparse evidence is largely descriptive and focuses on manufacturing enterprises. While local capability in developing countries is touted as important for product development and adaptations, ${ }^{5}$ the empirical literature examining the role apprenticeship plays in building and enhancing capabilities of informal enterprises remains thin.

Firm learning processes leading to innovations are also found in developing countries to occur in interaction with other external actors (Mcdade and Malecki, 1997; Murphy, 2002; Oyelaran-Oyeyinka and Lal, 2006; Robson et al., 2009). Interaction, particularly among micro and small enterprises in developing countries, is argued to be particularly important for circulating market information about products (Goedhuys, 2007). Micro and small enterprises in developing countries are found to operate mainly in the informal economy (Benjamin and Mbaye, 2015), where evidence reveals a continuum of inter-related, and interconnected activities with formal enterprises ranging from production to subcontracting, employment, distribution, and supply (Chen, 2006). The informal economy, in other words, is found to be linked to the formal economy with mutual interactions (Hart, 2006; Kawooya, 2014). Empirical evidence assessing the role formal interactions play on the innovation activities of informal enterprises, however, remains few in SSA. Available empirical evidence, mainly, considers horizontal interactions in informal clusters (see Dawson (1992); Mcdade and Malecki (1997); van Dijk (2002)) or between registered enterprises (see for instance Barr (1999); Goedhuys (2007); Murphy (2002); Robson et al. (2009)). ${ }^{6}$

To understand innovations in SSA, it is imperative to understand innovations in informal enterprises and the institutions that support learning, the transfer and con-

3 Firms in developing countries are generally found to do little R\&D (Goedhuys, 2007; OyelaranOyeyinka and Lal, 2006).

4 Known exceptions include Frazer (2006); Velenchik (1995); Teal et al. (2008).

5 See among others van Dijk and Sandee (2002); Romijn (2002).

6 This is in exception of Gebreeyesus and Mohnen (2013); Kawooya (2014). 
version of local knowledge, and how these processes are linked to formal enterprises. Micro-level evidence on how knowledge is created and converted to value through learning processes in informal enterprises may provide some understanding of how to transform millions of lives in SSA (Kraemer-Mbula and Wamae, 2010d). This chapter aims to fill these research gaps using a unique informal enterprise survey data set collected in Ghana.

The chapter adds to the literature in several folds. Our study of informal enterprises and their innovation activities adds to the thin literature in SSA. While literature on apprenticeship - its nature and characteristics - in SSA exists, it remains underdeveloped (Teal et al., 2008), descriptive (Frazer, 2006) and fails to analyse its effect as a critical learning process on innovation activities of informal enterprises. The related empirical literature available concentrates on learning-by-doing7, manufacturing enterprises and remains inconclusive (see Gebreeyesus and Mohnen (2013); Oyelaran-Oyeyinka and Lal (2006)). The chapter departs by specifically examining apprenticeship and by broadening the definition, suggesting that enterprises through apprenticeship also acquire 'new' knowledge that challenges the original ways of doing things that may lead to new or significantly improved products. ${ }^{8}$ This chapter also moves beyond manufacturing enterprises to service enterprises where there is significant economic activity. We also extend the analysis in Gebreeyesus and Mohnen (2013), Goedhuys (2007), and Robson et al. (2009), by looking beyond the propensity to innovate to examine how technological innovations actually perform. To the best of our knowledge, few studies exist in the literature analysing formal interactions (see Gebreeyesus and Mohnen, 2013; Kawooya, 2014) and how it affects innovation activities of informal enterprises (see Gebreeyesus and Mohnen, 2013). As noted above, empirical literature in SSA has so far focused on horizontal interactions in informal clusters (see Dawson, 1992; Mcdade and Malecki, 1997; van Dijk, 2002) or between registered enterprises (see for instance Barr (1999); Goedhuys (2007); Murphy (2002); Mahemba and Bruijn (2003); Robson et al. (2009)). While these studies provide first-level evidence indicating the innovation enhancing effects of horizontal interactions, the effect of vertical interactions such as informal interactions remain largely missing in the literature. ${ }^{9}$ Kawooya (2014), however, analysed the effect of collaborative interaction between formal and informal enterprises on innovation activities of registered firms in Uganda, while Gebreeyesus and Mohnen (2013) analysed the effects of network on innovation performance of a footwear cluster in Ethiopia. ${ }^{10}$ This chapter goes further by mod-

7 Learning-by-doing is defined as a process where enterprises learn and practice to do better and 'efficiently' what they already know to do (Cohen and Levinthal, 1989, p. 570).

8 Bas (1989) refers to apprenticeship in Africa as 'pure on-the-job-training.'

9 Goedhuys (2007) revealed the existence of vertical interactions between innovative foreign owned firms and domestic firms in Tanzania.

10 Gebreeyesus and Mohnen (2013) measured network as the 'sum of the number of buyers, suppliers, and competitors with whom the firm collaborates on information and experience exchange.' We considered this to include both informal and formal collaborators. 
elling both collaborative and competitive interactions and how different they may affect innovation strategies of informal enterprises.

The data used in this chapter was collected in two urban cities in Ghana, Accra and Tema, between May and June 2016. Using this new field data, on both manufacturing and service sector enterprises, this chapter contributes to the literature by empirically examining the effect of apprenticeship and formal interactions on the innovation performance of informal enterprises. Our estimation results reveal a significant and positive effect of apprenticeship, and formal interaction on enterprises' innovation performance, in the general model. Separating formal interactions, we found enterprises with competitive interactions tend to have strong positive effect on innovation performance, while enterprises with collaborative interactions have strong negative effect on innovation performance. Apprenticeship remains significant in the extended model.

The rest of the chapter is structured as follows: Section 5.2 presents review of related literature on informality, informal innovations, learning mechanisms- apprenticeship and formal interaction- largely in the context of SSA. Section 5.3 discusses our survey data and methodology employed in the empirical analysis of this chapter. Sections $5 \cdot 4$ and 5.5 present discussions of our results and conclusions respectively.

\subsection{Related literature}

This section presents literature in the context of SSA, on: informality, innovation, apprenticeship, and interactions.

\subsubsection{Informality and innovations in SSA}

Recent decades have seen rising informality around the globe. In developing countries, the informal economy remains a 'success', a 'universal feature', dynamic and a source of livelihood to many, especially urban dwellers (Hart, 2006). The informal economy is heterogeneous (Sindzingre, 2006), largely composed of small and medium-scaled enterprises that often have a dynamic mechanism to adjust quickly to market signals in terms of changes in demand.

Despite the recognition, informality and activities of informal enterprises remain largely seen as negative (La Porta and Shleifer, 2008). While a unique definition is missing in the literature, informal enterprises are generally considered to be those 'that are not registered and are legally outside the tax net' (Guha-Khasnobis et al., 2006, p.4). In Ghana, for example, an informal enterprise is defined as an enterprise 
not registered at the Registrar General's Department. ${ }^{11}$ This definition, as we found during the survey, does not imply that informal enterprises are outside the reach or mechanisms of official governance. On the contrary, we recognised that a majority of the enterprises that are not registered, that is they do not have official business operation certificates, pay local municipal taxes and property taxes to agents of the municipality, and were found to be well-structured. The conception that informality is equivalent to non-payment of taxes may therefore be questionable.

Innovation, on the other hand, has gained both policy and research interest over the last decade in Africa. Innovation activities, however, remain understood as a sole prerogative of registered firms, research institutions and universities through research and development (R\&D). This thinking is manifested in the African Science, Technology and Innovation initiatives (ST\&I) implemented through the NEPAD African Science, Technology and Innovation Indicators (ASTII) Initiative where new innovation policies are being enacted and implemented across the continent to understand, promote and drive innovations in formal institutions for Africa's transformation. ${ }^{12}$ As a result, available empirical evidence in SSA mainly focuses on formal enterprises (Goedhuys, 2007; Mahemba and Bruijn, 2003; Murphy, 2002; Oyelaran-Oyeyinka and Lal, 2006; Robson et al., 2009). This may be explained by the subsequent availability and improvement in the quality of firm-level data. The majority of these studies, however, concentrate on manufacturing enterprises. Adding to the thin literature on both manufacturing and service sector enterprises, Robson et al. (2009), for instance, analysed the effects of various entrepreneurial and firm-level characteristics on seven proxies of innovation. Distinguishing between two main types of innovations, novel and incremental, the authors found incremental innovations to be most prevalent in Ghana.

Innovation activities in the informal economy remain largely ignored in the policy sphere (Cozzens and Sutz, 2014; de Beer et al., 2013; Kraemer-Mbula and Wamae, 2010b). According to de Beer et al. (2014, p. 16), the lack of understanding of the informal economy and informal innovations hinder the understanding of innovations in Africa as a whole. Despite the policy neglect, innovation and the innovation activities of informal enterprises in SSA continue to gain research attention. ${ }^{13}$ While evidence remain sparse, recent case studies in SSA indicate widespread nature of innovations in the informal economy (see Bull, et al. 2016; Dawson, 1992; Essegbey and Awuni, 2016; Fu et al., 2014; Mcdade and Malecki, 1997; Konte and Ndong, 2012; Kraemer-Mbula and Wamae, 2016; van Dijk, 2002). Exploring the innovation activities of 25 informal enterprises producing home and personal products in South Africa, Kraemer-Mbula (2016) found the presence of both product and process innovations. The author, however, found these innovations to be incremental, systemic and mainly

11 This is the definition of informal enterprises employed in this chapter.

12 Charmes et al. (2016) indicated policy redirections towards including informal innovations in the NEPAD African Science, Technology and Innovation Indicators (ASTII) Initiative.

13 See de Beer et al. (2013); Kraemer-Mbula and Wamae (2010b) for review on informal innovations in SSA. 
aimed at satisfying customer needs. Similar conclusions were also drawn from related case studies in the informal herbal industry of Ghana (see Essegbey and Awuni, 2016) and in the informal metal working sector in Nairobi, Kenya (see Bull, et al. 2016). To understand innovation and diffusion of innovations in developing countries, the Diffusion of Innovation in Low Income Countries (DILIC) project conducted a survey of 500 firms from both formal and informal sectors in Ghana. Summary conclusions from the study indicates the prevalence of incremental innovations in the informal sector (about $72 \%$ ) of sampled enterprises (Fu, et al., 2014). Fu et al. (2015) studied innovation, informality and firms' growth in low-income countries using data from both informal and formal manufacturing firms in Ghana. Decomposing innovation into technical and learning, the authors found informal enterprises to be engaged in innovations. The authors also found learning innovating informal firms to have higher productivity compared to the productivity of their counterparts.

Informal enterprises, therefore, engage in incremental innovation activities based on knowledge aquired through non-R\&D based learning processes. According to Kraemer-Mbula and Wamae (2010a, p.83), 'A first step towards creating the ability to convert knowledge to value in Sub-Saharan Africa is to study innovation and learning process in sectors that account for a significant part of these economies.' This is the objective of the chapter.

\subsubsection{Learning in $S S A$}

The role of knowledge, technology adoption and adaptation in accelerating economic progress in developing countries is widely emphasised in development economics. Local capability development and enhancement through learning is found to be critical in this process (Cohen and Levinthal, 1989; Lall, 2000; Romijn, 2002; Kraemer-Mbula and Wamae, 2010d).

The literature on firm learning processes, however, acknowledges that various sources of knowledge have different effects on technological trajectory of firms (see Malerba, 1992; Oyelaran-Oyeyinka and Lal, 2006). Malerba (1992) identified and summarised learning processes into two main broad classifications as internal and external sources. Internal learning is argued to originate from the day to day activities of firms and includes 'learning by doing', 'learning by using' and 'learning by searching' (R\&D) while external learning is generated outside of the firm's internal day to day activities and includes 'learning by interacting', 'learning from inter-industry spillovers' and 'learning from advances in science and technology' (Malerba, 1992, p.848). These different types of learning processes are not exclusive as firms may adopt a mix of internal and/or external learning sources at the same time (Malerba, 1992). In other words, complementarity may exist between multiple learning processes that may reinforce the innovation activities of firms. In developing countries, the empirical liter- 
ature has identified several combinations of learning processes such as- R\&D (Goedhuys, 2007), training (Oyelaran-Oyeyinka and Lal, 2006), interactions and networks (Goedhuys, 2007; Mahemba and Bruijn, 2003; Murphy, 2002; Robson et al., 2009), and learning-by-doing (Gebreeyesus and Mohnen, 2013; Oyelaran-Oyeyinka and Lal, 2006), as important for firms' innovation activities. The available innovation literature mainly focuses on formal enterprises and ignores the dual economic structure that may define learning in SSA. In exception, Gebreeyesus and Mohnen (2013) introduced learning-by-doing and network into their analysis to understand the product innovation activities of informal clusters in Addis Ababa, Ethiopia. Findings from the literature, however, remain inconclusive. Mahemba and Bruijn (2003), for instance, found positive and significant effect of skilled workers on firm innovativeness. Robson et al. (2009), Goedhuys (2007) and Mahemba and Bruijn (2003) found training to have insignificant effect on the tendency of the enterprise to innovate. Robson et al. (2009) also found enterprises with owners having higher educational attainments tend to be much innovative.

Learning processes in developing countries are, in part, influenced by the learning processes and experiences of informal enterprises that dominate these economies (Kraemer-Mbula and Wamae, 2010d). In this chapter, we examine two often neglected learning processes in informal enterprises: apprenticeship (internal learning process) and formal interaction (external learning process).

\subsubsection{A Apprenticeship in SSA}

In developing countries, apprenticeship is considered as an internal learning process that serves as a source of knowledge (Oyelaran-Oyeyinka and Lal, 2006). This process creates skills and serves to transfer and exchange local knowledge thereby improving local capabilities and abilities. Local capabilities and competencies provide an opportunity to satisfy local needs through innovations (Kraemer-Mbula and Wamae, 2010d).

In Africa, apprenticeship is unique and popular in the informal economy, where it plays a key role as an institution of learning (Frazer, 2006; Velenchik, 1995; Bas, 1989). It is integral to African societies (Bas, 1989) and can be considered as a cultural interactive learning and knowledge accumulation process where business practices and skills are embedded into younger apprentices. It is evidenced to be most prevalent in West Africa (Velenchik, 1995) where job training of younger people to acquire practical skills occur. Teal et al. (2008) found apprenticeship to provide socio-economic benefits for large pool of young people, in terms of jobs, to earn a living. The mostly practical knowledge and skills provided in apprenticeship system can help solve local problems that confront Africa today. ${ }^{14}$ These 'modest' improvements in society

14 See Teal et al., 2008; Frazer, 2006; Velenchik, 1995; and Bas, 1989 for deeper perspectives on apprenticeship from a developing country context. 
and the capability of enterprises are often taken for granted in Africa. 'Even a very modest rise in the capabilities can make the difference between abject poverty and a respectable income that allows the satisfaction of basic minimum needs' (Romijn, 2002, pp. 30 \&31).

In Ghana, apprenticeship remains popular (Velenchik, 1995) and it involves training in a specific enterprise and skill to perform typically specific jobs using specific business praticises and a unique technology over a specified period (Frazer, 2006; Teal, Monk and Sandefur, 2008), usually 4 years. ${ }^{15}$ The institution of apprenticeship is important for small enterprises (Velenchik, 1995), but also serves as a support mechanism for family, relatives and friends both in economic and social terms. By providing prospects for young people to acquire practical market skills and knowledge, this creates opportunities for them to make a living. For example, one respondent who owns a hairdressing salon in Accra, said that the institution of apprenticeship offers her the opportunity to give back to society by passing on to others the skills she acquired from her own apprenticeship. After the apprenticeship period, graduates often go on to establish their own enterprises or continue to work in the masters enterprise. Few enterprise owners acknowledged having some of their former apprentices working in large formal enterprises. Teal et al. (2008), using a national representative survey, found the share of apprentices in the labour force in Ghana to be almost $25 \%$. Statistics cited in Frazer (2006, p. 263), puts the percentage of entrepreneurs in the manufacturing sector who have gone through apprenticeship in Ghana to be 55.6\%. In urban Ghana, apprenticeship remains a major form of skill transfer (Teal et al., 2008).

Today, despite the expansion of formal and vocational education and the perception that it is for the less intelligent, apprenticeship as a cultural system of training persists and remains relevant in transmission of skills at low cost (Bas, 1989). Formal technical and vocational institutions are criticised for their theoretical approach and failure to transfer comprehensive knowledge and relevant skills for the local context (Bas, 1989; Frazer, 2006). Apprenticeship, however, has been found to be practical and less theoretical (Frazer, 2006; Kawooya, 2014; Bas, 1989), and found to teach business and customer practices such as bargaining, buying and selling, social skills, etc. relevant for enterprises (Bas, 1989). Apprenticeship institution seems to know and understand the perculiar nature of demand, technologies and the learning required for solving local problems. Examples can be cited from Kawooya (2014), where he found that informal artisans had specific technical skills for solving problems that are even lacking in the formal sector.

Despite the importance of apprenticeship in Africa, its significance is often neglected in the economic literature (Frazer, 2006; Teal et al., 2008; Velenchik, 1995). Studying apprenticeship contracts, small enterprises and credit markets in manufaturing enterprises in Ghana, Velenchik (1995) found apprenticeship to be widespread and critical in transfering entrepreneurial skills. The author also found apprenticeship to

15 In Germany, for instance, apprenticeship or on-the-job-training is found to be general, that is, skills learnt are not firm-specific and it is regulated by a formal agency (see Acemoglu and Pischke (1998)). 
be a critical source of capital for enterprises, particularly, constrained financially with limited access to financial markets. In the context of manufacturing enterprises, Frazer (2006) formulated a theoretical framework, largely based on Becker (1962), examining apprenticeship and the remuneration of the apprenticed in Ghana. Applying data to the model and using two groups of apprentices, 'self-employed former apprentices and employee former apprentices', the author found employee former apprenticed workers to be more productive than apprenticed workers trained from elsewhere, emphasising the importance of the specific nature of knowledge acquired from apprenticeship (Frazer, 2006). This strand of the literature, however, mainly focuses on wage returns to apprenticeship in formal enterprises. ${ }^{16}$

While these studies advance our understanding, the role apprenticeship plays in generating new products in informal enterprises remain thin in the literature. Studies by Kawooya(2014) and McDade and Malecki(1996) found evidence of apprenticeship as a learning process for innovation in informal enterprises in SSA. Their evidence, however, remains descriptive. In the context of empirical evidence, Gebreeyesus and Mohnen (2013) found insignificant effect of on-the-job training and practical experience (defined as average monthly tenure of workers) on the intensity of innovation in a cluster of informal enterprises in Addis Ababa, Ethiopia. In this chapter, we seek to integrate the above available evidence to empirically assess how apprenticeship affects the performance of technological innovations in informal enterprises.

\subsubsection{B Interactions and innovation in $S S A$}

The literature establishing innovation as an outcome of complex, systemic interactions between actors is ample and well advanced (see among others Lundval, 1988). Networks, interactions and relations between firms, research institutions and government agencies, among others, serve as a conduit through which knowledge flows. The knowledge transfer occuring through collaborative and competitive interactions can be accumulated, transferred and adapted to improve the production processes of the firm. The learning process that occurs through these interactions is known to generate knowledge fundamental for innovation (Lundvall, 1988; Murphy, 2002; Hausman, 2005; Kraemer-Mbula and Wamae, 2010c; Legros and Galia, 2011).

Interaction between actors is found to be weak in SSA (McCormick and Atieno, 2002; Oyelaran-Oyeyinka and Lal, 2006; Kraemer-Mbula and Wamae, 201ob). Plethora of evidence, however, exists indicating the importance of interactions in SSA (see Dawson, 1992; Mcdade and Malecki, 1997; Barr, 1999; McCormick and Atieno, 2002; Murphy, 2002; van Dijk, 2002; Mahemba and Bruijn, 2003 ). Empirical studies find interactions between firms to be particularly important for innovation (Murphy, 2002; Goedhuys, 2007; Robson et al., 2009). Using firm data sets from Tanzania, for exam-

16 Ample theoretical and empirical literature exists on general training and returns to training. See for example Acemoglu (1997); Acemoglu and Pischke (1998); Legros and Galia (2011); Mincer (1993). 
ple, Goedhuys (2007) analysed the effect of different learning mechanisms on the product innovativeness of local- and foreign-owned firms. The author finds intensive collaboration to be a critical learning mechanism driving product innovations particularly in local firms in Tanzania. Comparing the effect of local collaborations among locally-owned firms, on the one hand, and foreign-owned firms, on the other hand, Goedhuys (2007) found that local collaborations drive product innovations in locallyowned firms. Similar conclusions were also found by Murphy (2002) in Mwanza, Tanzania, based on primary data.

The available empirical evidence in SSA, however, largely fails to consider formal interactions. Recent evidence in SSA reveals the nature of formal interactions to be 'highly complex' and 'symbiotic' (Kawooya, 2014). According to Kraemer-Mbula and Wamae (2010d, p.54), the nature of formal interactions evidenced in SSA can be largely explained by the socio-political and historical background of most African countries. For instance, a recent case study conducted by Kawooya (2014) on CEDAT's Gatsby Garage in Uganda, a registered entity, confirmed formal interaction as a critical mechanism resulting in innovations in formal enterprises. Gebreeyesus and Mohnen (2013) also found results confirming the interactive nature of innovations in informal clusters in Addis Ababa, Ethiopia. The authors found small and informal firms with dense networks (measured as the number of suppliers, buyers and competitors firm engage with in terms of exchange of information and experience) to have a more statistically positive probability of introducing innovation.

First-hand experiences of the symbiotic nature of formal interactions were realised during our field survey. We found during the fieldwork that interactions between formal and informal enterprises are highly structured and transcend supply interactions. The interactions are also sometimes complementary, and took forms like sub-contracts where formal enterprises hire informal enterprises to provide specific services. A manager of a spare part enterprise near Rana motors located in Tema, indicated that he has a strong affiliation with some registered firms in Tema both as suppliers of goods and as subcontractors. His agents often refer clients to him for specific services. Owner of a carpentry shop in Mamprobi, indicated that as a result of not having certain machines for specific designs, they employ the services of registered firms in timber market located in central Accra. During these interactions, they learn of some new designs which they often incorporate into their products. The carpentry shop owner revealed the importance of these complementary interactions in solving daily hindrances to their business. The owner of a barbering shop near Tema General Hospital, also indicated that due to competition particularly from other registered, modern and state of the art barbering shops, they also buy and use instruments such as sterilisers, new and well maintained shaving machines as well as introducing free complementary products such as after shave hair washing and a credit system for customers in order to stay in business. The owner also indicated the improvement in business when he fixed air-conditioning system in the shop. The owner acknowledged they often go to shave their hair in some of the 'talk-of-the-town' barbering shops as well as ask their 
clients about services provided to them in some of these competing shops for information. Based on the information accessed and exchanged, he adapts and upgrades services he provides to his clients.

While these relationships exist in many other forms in SSA, the empirical analysis of the effects of these complex interactions (co-operative and competitive) as a conduit for knowledge and innovations in informal enterprises remain missing. For progress in developing countries, according to Guha-Khasnobis et al. (2006), there is a need to transcend beyond the traditional dichotomy of formality and informality and understand the realities of economic activities. The chapter aims to achieve this.

\subsection{METHODOLOGY}

\subsubsection{Empirical model}

The objective of this chapter is to test how learning processes affect innovation activities of informal enterprises. This section presents the model used in the analysis. We formulated separate econometric frameworks for each variable of interest as below.

\subsubsection{A Formal Interaction equations}

The definition of formal interaction in the context of this chapter refers to informal enterprises that had a form of relationship with registered enterprises (see Appendix C.1, Question number H.2) over the last 3 fiscal years, that is, between 2013 and 2015. Formal interaction is hence a dummy variable. ${ }^{17}$ We proceeded appropriately to specify a probit model as:

$$
\begin{gathered}
\text { Formal Interaction } n_{i}^{*}=z_{i} \delta_{1}+\sigma_{i} \\
\text { Formal Interaction }_{i}=\left\{\begin{array}{l}
1 \text { ifFormal Interaction } \\
0 \text { otherwise }
\end{array}\right.
\end{gathered}
$$

where Formal Interaction ${ }_{i}^{*}$ is a latent variable indicating whether enterprise $i$ had any form of interaction with the formal economy between the period under cosideration

17 Variations in the degree and content of interactions are recognised in the literature in SSA (see, for example, Gebreeyesus and Mohnen, 2013). Unlike Gebreeyesus and Mohnen (2013), we are unable to model the heterogeneity in the degree of interactions across enterprises due to data limitations. 
and $z_{i}$ refers to a vector of enterprise, location and industry specific covariates that affect the interaction status of an enterprise. Formal Interaction $n_{i}$ is a dummy variable with 1 indicating enterprise has an interaction with the formal economy and o indicating otherwise.

The specific type of interaction matters for small firm innovativeness (Hausman, 2005). To test this, we further specified separate probit models based on Question number H.3, where we decomposed formal interaction into competitive and collaborative as:

$$
\begin{aligned}
& \text { Compete }_{i}^{*}=z_{i} \delta_{2}+\mu_{i} \\
& \text { Compete }_{i}=\left\{\begin{array}{l}
1 \text { if } \text { compete }_{i}^{*}=1 \\
0 \text { otherwise }
\end{array}\right. \\
& \text { Collaborate }_{i}^{*}=z_{i} \delta_{3}+\gamma_{i} \\
& \text { Collaborate }_{i}=\left\{\begin{array}{l}
1 \text { if collaborate }{ }_{i}^{*}=1 \\
0 \text { otherwise }
\end{array}\right.
\end{aligned}
$$

where Compete $_{i}^{*}$ is a latent variable indicating whether enterprise $i$ has a competitive formal interaction over the last 3 fiscal years while Collaborate $e_{i}^{*}$, a latent variable indicates whether enterprise $i$ has collaborative formal interaction over the last 3 fiscal years. $z_{i}$ refers to a vector of enterprise, location and industry specific covariates that may affect both competitive and collaborative formal interactions status of an enterprise.

Enterprise-specific characteristics in $z_{i}$ are a set of exogenous variables including dummies capturing whether the enterprise would like to formalise ('formal'), and if lack of access to finance is a major obstacle to the business ('lack of access to finance'). Both 'formal' and 'lack of access to finance' are believed to be positive determinants of formal interaction. For instance, enterprises with the desire to formalise in the future are more probable to make alliances with formal businesses than their counterparts. Enterprises with financial constraints are also obviously more probable to form strategic links with formal businesses in order to expand their credit options.

\subsubsection{B Apprenticeship equation}

In order to explore apprenticeship as a learning process on innovation performance, the survey asked respondents the number of apprentices in the enterprise in both years, that is, 2013 and 2015 (see Appendix C.1, Question number F.5). Measuring 
apprenticeship as the logarithm of the total number of apprentices in $2013,^{18}$ we formulate a log-linear regression model as:

$$
\text { Apprenticeship }_{i}=x_{i} \delta_{4}+\varepsilon_{i}
$$

where Apprenticeship ${ }_{i}$ is a continuous variable indicating the logarithm of the total number of apprentices in the enterprise in 2013. $\delta_{4}$ is a vector of parameters to be estimated. $x_{i}$ refers to a vector of firm, location and industry specific covariates that affect apprenticeship in an enterprise.

Firm-specific covariates in $x_{i}$ are motivated by Velenchik (1995) and Teal et al. (2008). In addition, we also introduce covariates such as 'formal' and 'apprenticed owner'. 'Formal' is a dummy variable capturing whether the enterprise would like to formalise or otherwise. We hypothesise that enterprises that desire to formalise in the future tend to train more apprentices as a transition mechanism. As noted earlier, some owners indicated that they train apprentices as a way of giving back to society. We tested this empirically by examining whether enterprises owned by former apprentices ('apprenticed owner') tend to be involved more in apprenticeship.

\subsubsection{Innovation equations}

Several definitions of product innovation exist in the literature. In this context, product innovation is defined broadly following OECD and Eurostat (2005, paragraph 156) as the 'introduction of a good or service that is new or significantly improved with respect to its characteristics or intended uses. This includes significant improvements in technical specifications, components and materials, incorporated software, user friendliness or other functional characteristics.' Following van Dijk and Sandee (2002), the study further broadened the Oslo Manual's definition to capture the local understanding of what product innovation is, to: new/significant changes to product design, new pricing strategies, introducing completely new product stock, and new service delivery methods. ${ }^{19}$ During our survey, respondents were asked extensive questions on product innovation (see Appendix C.1, Section B). Enterprises were first asked if they introduced new or significantly improved products between 2013 and 2015 (see Appendix C.1, Question number B.1). The response to this question is either a yes or a no. The variable Innovation ${ }_{i}^{*}$, is a latent variable indicating whether the enterprise introduced product innovations over the period from 2013-2015 or otherwise. Product innovative enterprises were then asked to estimate the percentage of

18 This is constructed as the logarithm of the total number of apprentices the enterprise had in 2013 plus 1. See Appendix D.1.

19 The definition was broadened after piloting the survey instrument. 
total sales from all innovative products introduced from fiscal year 2013-2015 (see Appendix C.1, Question number B.4). Based on this question, we followed Legros and Galia (2011) and Mairesse and Mohnen (2002) to construct our performance variablePerformance_Innovation - defined as the log share of real total sales per worker in 2015 due to product innovation.

Firms are identified to engage in multiple learning processes at the same time (Malerba, 1992). This suggests that firms that engage in different learning processes concurrently enhance their innovativeness than otherwise. As a result, we introduce both apprenticeship and formal interaction to examine how these learning processes affect the innovativeness of enterprises. Improvement in the internal capabilities of firms is found in the literature to improve innovative activity (Cohen and Levinthal, 1990). Apprenticeship enhances the internal capabilities of enterprises and also serves to provide free labour resource to enterprises (Velenchik, 1995). We hypothesis, therefore, that enterprises with higher number of apprentices tend to undertake more product innovative activity. As noted, interactions between firms serve as a conduit through which knowledge essential for innovative activity flows in SSA (Murphy, 2002; Mahemba and Bruijn, 2003; Goedhuys, 2007). It follows that informal interaction is a key channel through which knowledge flows for informal innovativeness.

Due to possible selection problems resulting from the survey design (see Mairesse and Mohnen, 2002), we proceeded by following Legros and Galia (2011) and Mairesse and Mohnen (2002) to formulate a Type II Tobit model as:

Selection equation

$$
\begin{gathered}
\text { Innovation }_{i}^{*}=\text { Apprenticeship }_{i} \delta_{5}+\text { Formal Interaction }_{i} \delta_{6}+M_{i} \delta_{7}+\rho_{i} \\
\text { Innovation }_{i}=\left\{\begin{array}{l}
1 \text { if innovation } \\
0 \text { otherwise }
\end{array}\right.
\end{gathered}
$$

Regression equation

$$
\text { Performance_Innovation }_{i}=\text { Apprenticeship }_{i} \delta_{8}+\text { Formal Interaction }_{i} \delta_{9}+Q_{i} \delta_{10}+\mathcal{E}_{i}
$$

where Innovation $_{i}^{*}$ is a latent variable indicating whether enterprise $i$ introduced product innovations over the period 2013-2015. Innovation $_{i}$ is a dummy variable taking the value 1 if the enterprise innovated and o otherwise. Performance_Innovation shows the log share of product innovations in real total sales per worker in 2015. In line with Classen et al. (2014), Gebreeyesus and Mohnen (2013), and Robson et al. (2009), $M_{i}$ and $Q_{i}$ refer to a vector of enterprise, location and industry specific covariates that may affect the innovation status and the performance of product innovations of an enterprise respectively. In both the innovation and performance of innovation equations, 
we specifically include dummies indicating whether the owner of the enterprise is a former apprentice and whether the enterprise lacks access to finance. Innovation is a costly process and access to finance has been found to be important for firm innovation (see for example Ayyagari et al. (2011)). We, therefore, expect enterprises that have financial constraints to be less innovative and perform less in terms of innovative sales.

\subsubsection{Extensions to model}

In highly concentrated markets where few large firms dominate, incentives to innovate tend to be low as new products are easily imitated (Aghion et al., 2005; Hausman, 2005; Sorescu et al., 2003). Due to this, market leaders may tend to collaborate and use 'laggard' firms as channels for distribution. Empirical evidence indicates that 'channel relationships' between large and small firms exist, and are used as a medium by the former to influence the innovativeness of the latter (Hausman, 2005). For example, some retailers indicated during our survey how their suppliers specifically curtailed them from expanding their product range to competitive and non-competitive products on the side. The inability to diversify the range of products sold by small firms reduces innovativeness (Hausman, 2005). On the other hand, markets with firms that are 'neck-to-neck' tend to be more competitive leading to more innovativeness as new innovations provide the incumbent some competitive urge (Aghion et al., 2005; Hausman, 2005). The foregoing suggest that informal enterprises with collaborative formal interactions operate in non-competitive markets and tend to be less innovative while enterprises with competitive formal interactions operate in competitive markets and tend to be more innovative.

In extension, we further decomposed our innovation equation to include the types of formal interactions (equations (5.21)-(5.32)) as:

Selection equation

$$
\text { Innovation }_{i}^{*}=\text { Apprenticeship }_{i} \delta_{11}+\text { Compete }_{i} \delta_{12}+\text { Collaborate }_{i} \delta_{13}+M_{i} \delta_{14}+\rho_{i}
$$

$$
\text { Innovation }_{i}=\left\{\begin{array}{l}
1 \text { if innovation } \\
0 \text { otherwise }
\end{array}\right.
$$

Regression equation

$$
\begin{array}{r}
\text { Performance_Innovation }_{i}=\text { Apprenticeship }_{i} \delta_{15}+\text { Compete }_{i} \delta_{16}+\text { Collaborate }_{i} \delta_{17}+ \\
Q_{i} \delta_{18}+\mathcal{E}_{i}
\end{array}
$$


where Compete C $_{i}$ is a dummy variable indicating whether enterprise $i$ has a competitive formal interaction while Collaborate $i$ is a dummy variable indicating whether enterprise $i$ has formal collaborative interaction. $M_{i}$ and $Q_{i}$ follow from equations 5.51 and 5.53 respectively, and they refer to a vector of enterprise, location and industry specific covariates that may affect the innovation status and the performance of product innovations of an enterprise respectively.

\subsubsection{Econometric issues and estimation strategy}

The decision to innovate is known to be non-random. Innovation activities are affected by a plethora of factors and often, only a sample of firms innovate. The fact that only a sample of enterprises actually innovates is confirmed in Table 5.1, where $27 \%$ of the sampled enterprises did not introduce any product innovation. To test for possible selection bias, we estimated equations (5.51)-(5.53) using two procedures, namely the Heckman two-step approach (see Heckman (1979)) and the Conditional Mixed Process (cmp) with selection (see Roodman (2011)). The Heckman procedure estimates the innovation equations in two steps to correct for possible selection bias in innovation performance while $\mathrm{cmp}$ conducts a joint estimation of both the selection and regression equations. Estimation results are shown in columns 1 and 2 of Table 5.2. Results from both models indicate no problem of selection bias in our data. ${ }^{20}$

Formal interaction may be associated with the disturbance term (Gebreeyesus and Mohnen, 2013) and this may also be the case for apprenticeship (Teal et al., 2008). To test for possible endogeneity of our main regressors, we estimated a two-step procedure as in Cohen and Levinthal (1989) and Gebreeyesus and Mohnen (2013). In the first approach, we separately estimated probit and linear regression models on right-hand side variables, in addition to a set of explanatory variables deemed to affect formal interaction and apprenticeship respectively. Residuals from the first stage regressions were obtained and used as additional explanatory variables in each innovation equation. Bootstrapping standard errors in the second stage estimations, we found our residuals from the first stage to be highly insignificant indicating exogeneity of our main regressors- formal interaction and apprenticeship- in both innovation equations. This is an indication that we do not have a problem of unobservables.

Typically distributed disturbance terms of separate unrelated equations, in this case our innovation equations, 'can be correlated' (Roodman, 2011). We, therefore, proceeded by formulating our innovation equations into a system of equations with apprenticeship and interactions simultaneously explaining innovation. We followed Gebreeyesus and Mohnen (2013) to conduct a joint and simultaneous estimation al-

20 This conclusion is derived from the insignificance of both the mills ratio -lambda from the Heckman model (column 1) and rho_12 from the cmp model (column 2). 
lowing for correlation of errors between all equations in Conditional Mixed Process (cmp). The joint estimation approach, where disturbance terms from all equations share a 'multidimensional distribution' is found to offer efficiency advantages (Roodman, 2011, p.168). The results from the joint estimation of our system of equations are shown in columns 3 and 4 of Table 5.2. Results indicate a positive and strong significant correlation between error terms of the two innovation equations, indicating the appropriateness of the joint estimation approach. As a result, we proceeded by jointly estimating all models in $\mathrm{cmp}$, and allowing for free correlation of error terms between equations in Maximum Likelihood (ML).

\subsubsection{Data and descriptive statistics}

The chapter employs enterprise-level data collected on 513 non-farm informal enterprises in urban Ghana (Refer to Chapter 4 for detailed data description). ${ }^{21}$ Table 5.1 presents some descriptive statistics from our data. ${ }^{22}$ Out of 513 enterprises interviewed, 337 enterprises, representing about $66 \%$, were micro enterprises while 167 enterprises, representing $32 \%$, were small enterprises. The distribution shows that majority of the enterprises in the sample are micro, defined as enterprises with less than 5 workers (owner inclusive). Nine enterprises, making up about $2 \%$ of interviewed enterprises, were medium in size. Innovations are prevalent in our sampled enterprises. 372 enterprises, representing about $72.5 \%$, introduced product innovations with average percentage sales from all product innovations of about $19.516 \%$.

In terms of total employment, all enterprises on the average employed about 4 workers in 2015, with medium-sized enterprises employing 12 workers on the average. Micro and small enterprises, on the average, on the other hand, employed about 2 and 6 workers respectively. Apprenticeship is fairly low in our sample. Of the $5^{13}$ enterprises interviewed, only 83 (about $16.18 \%$ ) enterprises train apprentices, as seen in Table 5.1. In terms of size of the enterprises, apprenticeship is found per our descriptive to be most prevalent in medium-sized enterprises. About $33 \%$ of medium-sized enterprises train apprentices, on the average. The number of apprentices in micro and small enterprises is rather small, average of about 0.042 and 0.407 respectively. This may be due to the low skill levels required to run some of these businesses. This may also be, as found by Velenchik (1995), because larger enterprises tend to provide significant level of benefits to apprentices as compared with smaller enterprises. ${ }^{23}$ In our sample, the descriptives also show apprentices serve as a source of innovative ideas across all enterprises. Out of 83 enterprises, 49 representing about $59 \%$ of sampled enterprises indicated their apprentices are a source of their innovative ideas. There are

21 Since the number of enterprises is relatively small, our findings are specific to our sample at the point in time.

22 See appendix D.1 for definition and construction of all variables.

23 These advantages may take several forms such as provision of allowances, network, etc. 
approximately equal numbers of enterprises engaged in formal interaction in our sample. Just a little more than half of the enterprises interviewed indicated to have some form of relationship with the formal sector as compared to 255 enterprises that indicated to have no form of interaction. ${ }^{24}$ This is an indication that informal enterprises do have interactions with formal enterprises. Enterprises were then asked to indicate the specific types of interactions that exist with formal enterprises. The addition of enterprises engaged in both competitive and co-operative formal interactions is more than enterprises that have formal interaction because competitive and co-operative formal interactions are not exclusive. We found 34 enterprises in the sample to be engaged in both formal interactions. Enterprises are mainly engaged in competitive formal interactions. 218 sampled enterprises indicated to have competitive interactions with formal enterprises compared with 74 enterprises having collaborative interactions. This is an indication of weak collaborative interactions. An explanation may be that informal enterprises prefer to collaborate with other informal enterprises, due to proximity, similarity of products and prices of products. Table 5.1 also shows the distributions of our data based on location, sector and ownership. Informal enterprises are mainly engaged in services. Majority of enterprises (about 90.45\%) in our data are involved in the selling of goods or services, while only $9.55 \%$ of the enterprises make goods. Ownership distributions show about $58.48 \%$ and $41.52 \%$ of enterprises are owned by males and females respectively. Location specific descriptive also show about $61.8 \%$ of the enterprises are located in Accra while $38.2 \%$ of the enterprises are located in Tema.

$24 \overline{\text { In their case study, Kraemer-Mbula (2016) }}$ found $52 \%$ of sampled informal enterprises have no form of interaction with formal enterprises. 
Table 5.1: Description of data

\begin{tabular}{|c|c|c|c|c|}
\hline & ALL & $\operatorname{Micro}<5$ & Small(5-9) & Medium(10-19) \\
\hline Number of firms surveyed & 513 & 337 & 167 & 9 \\
\hline \multicolumn{5}{|l|}{ Product innovation } \\
\hline No. of all firms & 513 & 337 & 167 & 9 \\
\hline Innovators & 372 & 215 & 149 & 8 \\
\hline Non-innovators & 141 & 122 & 18 & 1 \\
\hline Sales, all product innovations (Mean $\%$ ) & 19.516 & 23.191 & 14.329 & $17 \cdot 375$ \\
\hline \multicolumn{5}{|l|}{ City of enterprise } \\
\hline Accra & 317 & 213 & 98 & 6 \\
\hline Tema & 196 & 124 & 69 & 3 \\
\hline \multicolumn{5}{|l|}{ Sector of firm } \\
\hline Manufacturing & 49 & 34 & 13 & 2 \\
\hline Services & 464 & 303 & 154 & 7 \\
\hline \multicolumn{5}{|l|}{ Ownership } \\
\hline Male & 300 & 194 & 104 & 2 \\
\hline Female & 213 & 143 & 63 & 7 \\
\hline \multicolumn{5}{|l|}{ Formal interaction } \\
\hline Yes & 258 & 177 & 74 & 7 \\
\hline No & 255 & 160 & 93 & 2 \\
\hline \multicolumn{5}{|l|}{ Type of formal interaction } \\
\hline Competition & 218 & 147 & 64 & 7 \\
\hline Collaboration & 74 & 55 & 16 & 3 \\
\hline \multicolumn{5}{|l|}{ Type of interaction by innovative ent. } \\
\hline Competition & 168 & 103 & 59 & 6 \\
\hline Collaboration & 38 & 25 & 10 & 3 \\
\hline \multicolumn{5}{|l|}{ Employment } \\
\hline Total employment 2015 (Mean) & 3.622 & 2.251 & 5.910 & 12.222 \\
\hline \multicolumn{5}{|l|}{ Apprenticeship } \\
\hline Yes & 83 & 48 & 32 & 3 \\
\hline No & 430 & 289 & 135 & 6 \\
\hline Number of apprentices (Mean) & 0.191 & 0.042 & 0.407 & 1.777 \\
\hline \multicolumn{5}{|l|}{ Apprentices, source of innovative ideas } \\
\hline Yes & 49 & 27 & 20 & 2 \\
\hline No & 34 & 21 & 12 & 1 \\
\hline
\end{tabular}


This section presents estimation results and discussions on the effects of apprenticeship and formal interactions - with extensions to collaborative and competitive interactions - on the introduction and performance of product innovations in Ghana.

Column 3 of Table 5.2 is our preferred model and it presents estimation outputs from the joint estimation of all 4 equations: product innovation, performance of product innovations, formal interaction, and apprenticeship equations. ${ }^{25}$ As indicated earlier, apprenticeship and formal interaction are both simultaneously introduced into both innovation equations. We used log share of real total sales per worker in 2015 due to product innovation, as a measure of product innovations performance. Our results are consistent across all estimation procedures. The result (Column 3) indicates a strong positive effect of formal interaction on both product innovation performance and the probability to introduce product innovations. Specifically, informal enterprises with ties in the formal economy on the average tend to have a higher probability of introducing product innovations. Our results also show innovative enterprises perform better in terms of sales of their innovative products per worker as compared to enterprises that do not have formal connections. This finding is consistent with evidence from the empirical literature in SSA. Various authors also found that, firms with dense networks tend to have a higher tendency to innovate. That is, local business interactions matter for innovation (Gebreeyesus and Mohnen, 2013; Robson et al., 2009). The results suggest that formal interactions, on the average, enhance the innovation process of informal enterprises.

Our results also show a strong positive effect of apprenticeship on the tendency of introducing product innovation, and on the performance of product innovation. In other words, we found informal enterprises with higher numbers of apprentices to have a higher propensity to introduce product innovations onto the market than otherwise. These enterprises also sell more of their innovative products per worker than their counterparts. We found this effect to be monotonic, that is, the higher the growth rate of apprentices, the higher the probability of introducing product innovations. In the course of apprenticeship, knowledge exchange occurs. The exchange of knowledge improves the internal absorptive capacity of enterprises and may be enabling enterprises to identify, imitate and transform knowledge into new or significantly improved goods and services. An apprentice in the course of training also serves to provide free labour resource and in some cases financial resource to the enterprise (Velenchik, 1995). These resources free up other resources of the enterprise, so the higher the number of apprentices, the higher the capacity of the enterprise to venture into doing new things that may result in product innovation and higher sales.

To understand the relationship between product and process innovations, as well as to explore the robustness of the results, we extended our innovation variable to technological product and process innovations (TPP) where introduction of innovation

25 See Table D.1 in appendix for estimation outputs for formal interaction and apprenticeship. 
is defined as enterprises that have introduced product and/or process innovations. Results shown in column 4 indicate same conclusions that firms with formal interactions tend to have strong positive effect on both the introduction and performance of technological innovations. Enterprises with higher numbers of apprentices also tend to have higher probability of introducing product innovations and higher sales of innovative products.

Other significant covariates in our full model (Column 3) include, among others, real total sales, crime, lack of access to finance, imitate formal firms, apprenticed owners and firm marketing. The market size of the enterprise is critical for the performance of new products. Using real total sales (logged and lagged 3 years) as proxy for market power of the enterprise, our results indicate enterprises with larger market share sell more of new product innovations. We, however, found market power to have positive but no significant effect on the probability of the enterprise to introduce new products onto the market. Enterprises with financial constraints as well as enterprises whose activities are hampered by crime, sell less of new products. Financially constrained enterprises also tend to introduce product innovations onto the market less. This is consistent with the literature and may be explained by the reluctance of formal financial institutions to advance loans and credits to micro and particularly informal enterprises. This finding, however, remains surprising given the rapid growth of the informal financial market and informal sources of finance/credit in developing countries. The innovative process is known to be costly and as a result, abnormally high interest rates on loans and credits may imply lack of financial resources for innovation. Informal enterprises with imitated innovations perform better in sales as compared to enterprises that do not. Enterprises owned by former apprentices tend to have less probability of introducing product innovations and also tend to perform less in terms of sales of innovative products. These may be due to the reason that these owners tend to be conservative towards new ideas, and the adoption and adaptation of new technologies. As a result, they tend to reject new designs and new products leading to less innovativeness. Marketing of firms' products helps to make products visible and this enhances sales of new products. This is indicated by our results showing that enterprises that undertake marketing perform better, on average, in sales of new products.

Statistically significant covariates in our apprenticeship equation include 'apprenticed owner' and 'lack of access to finance'. The results indicate that enterprise owners that apprenticed tend to have more apprentices, in line with our field evidence. Enterprise owners that would like to formalise also tend to train more apprentices. This may be that these enterprises are aware they require higher human capital to survive in the formal sector and as a result, train more apprentices to enhance their human capital as well as their financial base. These results also hold in the formal interaction equation where the results suggest owners that aim to register their enterprises tend to network more with formal businesses. Enterprises that lack access to finance also tend to align more with the formal sector (see Table D.1 in appendix). 
Table 5.2: Effect of interaction and apprenticeship on product innovation

\begin{tabular}{|c|c|c|c|c|}
\hline \multirow[t]{3}{*}{ Estimation method } & $\begin{array}{l}\text { Heckman } \\
\text { two-step }\end{array}$ & $\begin{array}{l}\text { Selection } \\
\text { FIML }^{b}\end{array}$ & \multicolumn{2}{|c|}{$\begin{array}{l}\text { Simultaneous equation } \\
\text { FIML }^{b}\end{array}$} \\
\hline & $(1)$ & $(2)$ & (3) & (4) \\
\hline & \multicolumn{4}{|c|}{ Performance of Innovation } \\
\hline Number of Apprentice (log) & $\begin{array}{c}0.101 \\
(0.155)\end{array}$ & $\begin{array}{c}0.094 \\
(0.137)\end{array}$ & $\begin{array}{l}1.071^{* * *} \\
(0.229)\end{array}$ & $\begin{array}{l}2.446^{* * *} \\
(0.315)\end{array}$ \\
\hline Formal interaction & $\begin{array}{c}0.145 \\
(0.105)\end{array}$ & $\begin{array}{c}0.150 \\
(0.102)\end{array}$ & $\begin{array}{l}1.857^{* * *} \\
(0.196)\end{array}$ & $\begin{array}{l}2.891^{* * *} \\
(0.205)\end{array}$ \\
\hline Family business & $\begin{array}{c}0.092 \\
(0.128)\end{array}$ & $\begin{array}{c}0.091 \\
(0.108)\end{array}$ & $\begin{array}{c}0.055 \\
(0.219)\end{array}$ & $\begin{array}{c}0.058 \\
(0.220)\end{array}$ \\
\hline Real total sales_2013 (log) & $\begin{array}{l}0.763^{* * *} \\
(0.043)\end{array}$ & $\begin{array}{l}0.762^{* * *} \\
(0.045)\end{array}$ & $\begin{array}{l}0.341^{* * *} \\
(0.067)\end{array}$ & $\begin{array}{l}0.337^{* * *} \\
(0.077)\end{array}$ \\
\hline Crime & $\begin{array}{l}-0.284^{* *} \\
(0.136)\end{array}$ & $\begin{array}{l}-0.251^{* *} \\
(0.114)\end{array}$ & $\begin{array}{l}-0.505^{* *} \\
(0.208)\end{array}$ & $\begin{array}{l}-0.406^{*} \\
(0.242)\end{array}$ \\
\hline Lack of access to finance & $\begin{array}{l}-0.349^{* * *} \\
(0.116)\end{array}$ & $\begin{array}{c}-0.354^{* * *} \\
(0.114)\end{array}$ & $\begin{array}{l}-0.425^{* *} \\
(0.210)\end{array}$ & $\begin{array}{l}-0.638^{* * *} \\
(0.243)\end{array}$ \\
\hline Apprenticed owner & $\begin{array}{l}-0.176 \\
(0.143)\end{array}$ & $\begin{array}{l}-0.184 \\
(0.134)\end{array}$ & $\begin{array}{l}-0.451^{* *} \\
(0.222)\end{array}$ & $\begin{array}{c}-0.879^{* * *} \\
(0.229)\end{array}$ \\
\hline Number of innovations & $\begin{array}{c}0.021 \\
(0.017)\end{array}$ & $\begin{array}{c}0.021 \\
(0.016)\end{array}$ & $\begin{array}{l}0.097^{* * *} \\
(0.026)\end{array}$ & $\begin{array}{c}0.134^{* * *} \\
(0.027)\end{array}$ \\
\hline Imitate formal sector & $\begin{array}{c}0.232 \\
(0.168)\end{array}$ & $\begin{array}{l}0.231^{*} \\
(0.122)\end{array}$ & $\begin{array}{c}0.555^{* * *} \\
(0.186)\end{array}$ & $\begin{array}{c}0.308 \\
(0.290)\end{array}$ \\
\hline Firm marketing & $\begin{array}{c}0.543^{* * *} \\
(0.184)\end{array}$ & $\begin{array}{c}0.543^{* * *} \\
(0.201)\end{array}$ & $\begin{array}{l}0.617^{* *} \\
(0.275)\end{array}$ & $\begin{array}{l}0.687^{* *} \\
(0.344)\end{array}$ \\
\hline & Prod & ct Innovat & $\mathrm{n}^{a}$ & TPP Innovation ${ }^{a}$ \\
\hline Number of Apprentice (log) & $\begin{array}{c}0.135 \\
(0.288)\end{array}$ & $\begin{array}{c}0.124 \\
(0.267)\end{array}$ & $\begin{array}{l}1.993^{* * *} \\
(0.170)\end{array}$ & $\begin{array}{c}2.455^{* * *} \\
(0.239)\end{array}$ \\
\hline Formal interaction & $\begin{array}{c}0.004 \\
(0.139)\end{array}$ & $\begin{array}{c}0.003 \\
(0.136)\end{array}$ & $\begin{array}{l}1.014^{* * *} \\
(0.072)\end{array}$ & $\begin{array}{l}1.083^{* * *} \\
(0.068)\end{array}$ \\
\hline Family business & $\begin{array}{c}0.002 \\
(0.174)\end{array}$ & $\begin{array}{c}0.001 \\
(0.169)\end{array}$ & $\begin{array}{c}0.180 \\
(0.111)\end{array}$ & $\begin{array}{c}0.111 \\
(0.105)\end{array}$ \\
\hline Real total sales_2013 (log) & $\begin{array}{c}0.009 \\
(0.043)\end{array}$ & $\begin{array}{c}0.011 \\
(0.040)\end{array}$ & $\begin{array}{c}0.023 \\
(0.033)\end{array}$ & $\begin{array}{c}0.017 \\
(0.032)\end{array}$ \\
\hline
\end{tabular}


...cont'd

\begin{tabular}{|c|c|c|c|c|}
\hline \multirow[t]{2}{*}{ Estimation method } & \multirow{2}{*}{$\begin{array}{l}\text { Heckman } \\
\text { two-step } \\
(1)\end{array}$} & \multirow{2}{*}{$\begin{array}{l}\text { Selection } \\
\text { FIML }^{b} \\
(2)\end{array}$} & \multicolumn{2}{|c|}{$\begin{array}{l}\text { Simultaneous equation } \\
\text { FIML }^{b}\end{array}$} \\
\hline & & & (3) & (4) \\
\hline & \multicolumn{3}{|c|}{ Product Innovation $^{a}$} & TPP Innovation ${ }^{a}$ \\
\hline Crime & $\begin{array}{l}-0.337^{* *} \\
(0.150)\end{array}$ & $\begin{array}{l}-0.346^{* *} \\
(0.147)\end{array}$ & $\begin{array}{l}-0.068 \\
(0.114)\end{array}$ & $\begin{array}{l}-0.126 \\
(0.121)\end{array}$ \\
\hline Lack of access to finance & $\begin{array}{c}0.027 \\
(0.150)\end{array}$ & $\begin{array}{c}0.043 \\
(0.150)\end{array}$ & $\begin{array}{l}-0.428^{* * *} \\
(0.129)\end{array}$ & $\begin{array}{l}-0.307^{* *} \\
(0.121)\end{array}$ \\
\hline Apprenticed owner & $\begin{array}{c}0.063 \\
(0.186) \\
\end{array}$ & $\begin{array}{c}0.079 \\
(0.183) \\
\end{array}$ & $\begin{array}{l}-0.389^{* * *} \\
(0.116)\end{array}$ & $\begin{array}{l}-0.571^{* * *} \\
(0.125)\end{array}$ \\
\hline mills -lambda & $\begin{array}{l}\text { o. .282 } \\
(0.637)\end{array}$ & & & \\
\hline sig_1 & & $\begin{array}{l}0.924^{* * *} \\
(0.048)\end{array}$ & $\begin{array}{l}2.12^{* * *} \\
(0.079)\end{array}$ & $\begin{array}{l}2.45^{* * *} \\
(0.085)\end{array}$ \\
\hline sig_4 & & & $\begin{array}{l}0.289^{* * *} \\
(0.021)\end{array}$ & $\begin{array}{l}0.290^{* * *} \\
(0.021)\end{array}$ \\
\hline rho_12 & & $\begin{array}{l}\text { o. .020 } \\
(0.062)\end{array}$ & $\begin{array}{l}0.812^{* * *} \\
(0.000)\end{array}$ & $\begin{array}{l}0.790^{* * *} \\
(0.178)\end{array}$ \\
\hline $\mathrm{N}$ & 499 & 499 & 499 & 499 \\
\hline Wald chi $^{2}$ & 549.68 & 866.50 & 3156.71 & 1878.40 \\
\hline Prob $>\mathrm{chi}^{2}$ & 0.000 & 0.000 & 0.000 & 0.000 \\
\hline
\end{tabular}

Notes: Robust standard errors in parentheses.

${ }^{a}$ The reported estimates are probit regression coefficients.

${ }^{b}$ Full-information maximum likelihood.

Used cmp Stata package for FIML estimations.

All regressions include 22 zones, firm size, sector, city and ownership dummies.

TPP Innovation refers to technological product and process innovation.

${ }^{*} \mathrm{p}<0.10,{ }^{* *} \mathrm{p}<0.05,{ }^{* * *} \mathrm{p}<0.01$.

The effect of formal interaction on the innovation performance of an enterprise may differ depending on the type of interaction. Next, we extend our analysis by decomposing formal interaction into competitive and collaborative interactions to analyse their separate effects on product innovation. Table 5.3 shows the estimation results from our baseline estimation to our full model where we introduced interactions to capture possible indirect mechanisms. Our results from the full model, shown in column 2 of Table 5.3, indicate a strong positive effect of competitive formal interaction on the performance of product innovations. That is, informal enterprises that com- 
pete in product markets are more likely to introduce innovations and perform better in terms of sales in the face of formal competition than otherwise. This result may be explained by the basic understanding of what sells and what do not sell in local product markets by informal enterprises. This basic understanding of the domestic market niche, coupled with the low cost of production due to the use of local resources, close customer relations and the dynamic nature to very easily adapt to the changing demands of consumers, particularly at the bottom of the pyramid, through new and cheaper products provide an incentive and a valuable competitive advantage for informal enterprises. This result is in line with Dawson, (1992), and Legros and Galia (2011) but contrary to Mahemba and Bruijn (2003). Mahemba and Bruijn (2003) found market competition to have no significant effect on the innovation activities of enterprises.

Collaborative interactions are found to be important for small enterprises that often require supplies of goods and services on credit (Mahemba and Bruijn, 2003). Majority of enterprises in our sample acknowledged lack of access to finance as a major obstacle to their business. We expected collaborative formal interactions, as a result, to be much useful for innovation activities of informal enterprises. Our results, however, indicate that informal enterprises with collaborative footholds in the formal economy tend to have a lower probability of introducing product innovations as compared to enterprises without this type of interaction. This result may be due to several reasons. The informal economy survives on the free sharing of ideas and ways of solving daily issues. This result may imply that informal enterprises as a result of the sharing 'norm', openly and freely share ideas with formal enterprises with whom they collaborate. As a result, new knowledge, and goods and services resulting from collaborations and sub-contracts, for example, may be claimed, adopted and commercialised by formal partners. This may lead to the loss of market power and autonomy. Formal partners may also be enterprises with competitive dominance in the product market and/or largely involved in service innovations which are mainly intangible. As a result, new collaborative products may not be directed to the needs of those at the bottom of the pyramid- in terms of product usage and price- and, on the other hand, not readily adoptable by informal partners. Formal partners may also be less innovative themselves. All these factors may conspire to reduce the innovation performance of informal enterprises. This finding is contrary to Goedhuys (2007), who found enterprises engaged in intensive local collaboration tend to have a higher probability of introducing product innovations. The result may be explained by the differences in the types of collaboration. While collaboration in this chapter may be considered vertical between formal and informal enterprises, the findings by Goedhuys (2007) pertain to collaboration between locally-owned registered firms, which may be considered a horizontal form of collaboration. 
Table 5.3: Effect of competition, collaboration and apprenticeship on product innovation

Estimation method Full-information maximum likelihood (FIML)

(1)

(2)

Performance of Innovation

\begin{tabular}{|c|c|c|c|}
\hline Number of Apprentice (log) & $\begin{array}{l}1.589^{* * *} \\
(0.433)\end{array}$ & $\begin{array}{l}1.964^{* * *} \\
(0.577)\end{array}$ & $\begin{array}{c}1.921^{* * *} \\
(0.558)\end{array}$ \\
\hline \multicolumn{4}{|l|}{ Type of formal interaction } \\
\hline Formal interaction- competitive & $\begin{array}{c}3.811^{* * *} \\
(0.308)\end{array}$ & $\begin{array}{l}3.154^{* * *} \\
(0.378)\end{array}$ & $\begin{array}{c}3 \cdot 571^{* * *} \\
(0.478)\end{array}$ \\
\hline Formal interaction-collaborative & $\begin{array}{l}-2.034^{* *} \\
(0.897)\end{array}$ & $\begin{array}{c}-1.886^{* * *} \\
(0.621)\end{array}$ & $\begin{array}{c}-1.926^{* * *} \\
(0.663)\end{array}$ \\
\hline Family business & & $\begin{array}{c}0.141 \\
(0.235)\end{array}$ & $\begin{array}{c}0.107 \\
(0.233)\end{array}$ \\
\hline Real total sales_2013 (log) & & $\begin{array}{l}0.384^{* * *} \\
(0.077)\end{array}$ & $\begin{array}{c}0.388^{* * *} \\
(0.079)\end{array}$ \\
\hline Crime & & $\begin{array}{l}-0.056 \\
(0.252)\end{array}$ & $\begin{array}{l}-0.048 \\
(0.256)\end{array}$ \\
\hline Lack of access to finance & & $\begin{array}{c}-0.526^{* *} \\
(0.254)\end{array}$ & $\begin{array}{l}-0.296 \\
(0.270)\end{array}$ \\
\hline Apprenticed owner & & $\begin{array}{l}-0.205 \\
(0.228)\end{array}$ & $\begin{array}{l}-0.212 \\
(0.243)\end{array}$ \\
\hline Number of product innovations & & $\begin{array}{c}0.101^{* * *} \\
(0.022)\end{array}$ & $\begin{array}{c}0.101^{* * *} \\
(0.023)\end{array}$ \\
\hline Imitate formal sector & & $\begin{array}{c}0.258 \\
(0.236)\end{array}$ & $\begin{array}{c}0.247 \\
(0.239)\end{array}$ \\
\hline Firm marketing & & $\begin{array}{l}0.509^{*} \\
(0.269)\end{array}$ & $\begin{array}{l}0.504^{*} \\
(0.265)\end{array}$ \\
\hline Compete $^{*}$ Lack of access to finance & & & $\begin{array}{l}-0.558^{*} \\
(0.292)\end{array}$ \\
\hline
\end{tabular}

Product Innovation ${ }^{a}$

\begin{tabular}{|c|c|c|c|}
\hline Number of Apprentice (log) & $\begin{array}{l}1.288^{* *} \\
(0.574)\end{array}$ & $\begin{array}{l}2.195^{* * *} \\
(0.538)\end{array}$ & $\begin{array}{l}2.182^{* * *} \\
(0.525)\end{array}$ \\
\hline
\end{tabular}

Type of formal interaction

Formal interaction-competitive $1.136^{* * *} 1.045^{* * *} \quad 1.058^{* * *}$ cont'd ... 
...cont'd

\begin{tabular}{|c|c|c|c|}
\hline \multirow[t]{2}{*}{ Estimation method } & \multicolumn{3}{|c|}{ Full-information maximum likelihood (FIML) } \\
\hline & (1) & $(2)$ & (3) \\
\hline & \multicolumn{3}{|c|}{ Product Innovation ${ }^{a}$} \\
\hline \multirow{3}{*}{ Formal interaction-collaborative } & $(0.274)$ & $(0.203)$ & $(0.210)$ \\
\hline & $-0.974^{* *}$ & $-0.672^{* * *}$ & $-0.679^{* * *}$ \\
\hline & $(0.389)$ & $(0.257)$ & $(0.255)$ \\
\hline \multirow[t]{2}{*}{ Family business } & & $0.229^{* *}$ & $0.224^{* *}$ \\
\hline & & (0.103) & $(0.104)$ \\
\hline \multirow[t]{2}{*}{ Real total sales_2013 (log) } & & 0.042 & 0.042 \\
\hline & & $(0.031)$ & $(0.033)$ \\
\hline \multirow[t]{2}{*}{ Crime } & & -0.146 & -0.136 \\
\hline & & $(0.125)$ & $(0.125)$ \\
\hline \multirow[t]{2}{*}{ Lack of access to finance } & & $-0.362^{* * *}$ & $-0.349^{* * *}$ \\
\hline & & (0.110) & (0.110) \\
\hline \multirow[t]{2}{*}{ Apprenticed owner } & & $-0.219^{*}$ & $-0.216^{*}$ \\
\hline & & $(0.130)$ & $(0.130)$ \\
\hline \multirow[t]{2}{*}{ sig_1 } & $2.833^{* * *}$ & $2.451^{* * *}$ & $2.490^{* * *}$ \\
\hline & (0.139) & (0.169) & (0.176) \\
\hline \multirow[t]{2}{*}{$\operatorname{sig} \_4$} & $0.291^{* * *}$ & $0.292^{* * *}$ & $0.291^{* * *}$ \\
\hline & $(0.022)$ & $(0.022)$ & $(0.022)$ \\
\hline \multirow[t]{2}{*}{ rho_12 } & $0.914^{* * *}$ & $0.860^{* * *}$ & $0.857^{* * *}$ \\
\hline & (0.046) & (0.074) & (0.074) \\
\hline $\mathrm{N}$ & 513 & 499 & 499 \\
\hline Wald chi $^{2}$ & 986.71 & 2538.21 & 2676.81 \\
\hline Prob $>\mathrm{chi}^{2}$ & 0.000 & 0.000 & 0.000 \\
\hline
\end{tabular}

Notes: Robust standard errors in parentheses.

Used cmp Stata package for FIML estimation.

All regressions include 22 zones, firm size, sector, city and ownership dummies.

${ }^{*} \mathrm{p}<0.10,{ }^{* *} \mathrm{p}<0.05,{ }^{* * *} \mathrm{p}<0.01$.

$a$ The reported estimates are probit regression coefficients.

Apprenticeship remains significantly positive in both the innovation and performance of innovation equations indicating that, apprenticeship improves the learning capabilities of enterprises to innovate. In addition, we found enterprises owned by family, on average, tend to have a higher probability of introducing product innovations, all other factors held constant. This is practical in the context, as family businesses may tend to have more resources available for innovation than enterprises with 
sole owners. We also analysed possible indirect mechanisms that may affect our innovation variables by introducing an interaction term in column 3 of Table 5.3. Our results show enterprises that have competitive interactions and consider lack of access to finance as an obstacle tend to perform less in terms of sales in product innovations per worker, as compared to their counterparts that compete without financial constraints. That is, financially constrained enterprises that compete with formal enterprises in product markets tend to perform poorly with their new products, compared to their counterparts. This may be explained by the bias against these types of enterprises in the financial market. This may also indicate the strong financial capability required to compete with formal enterprises.

\section{$5 \cdot 5$ CONCLUSION}

Learning processes in informal enterprises provide knowledge central for innovation and innovation policy in developing countries (Kraemer-Mbula and Wamae, 2010a). Despite the economic significance of informality and evidence of the pervasiveness of incremental innovations in the informal economy, empirical studies examining the relationship between learning processes and innovation activities of informal enterprises remain little in SSA. The chapter makes the case for and analyses the role apprenticeship and formal interactions play- as learning processes- on the innovation performance of informal enterprises, using a unique survey data set from Ghana.

Using a new primary data collected on 513 manufacturing and service informal enterprises in urban Ghana (in the cities of Accra and Tema), we formulated and estimated a structural model to account for selection and simultaneity biases. Our results show formal interaction on the one hand, and apprenticeship on the other hand, are significant and positive determinants of innovation in informal enterprises. Decomposing formal interactions, we have also shown that competitive formal interactions enhance the likelihood of innovations while collaborative formal interactions inhibit innovations in informal enterprises. Our results suggest apprenticeship improves the technological capabilities of enterprises to create, adapt and transform knowledge into new or significantly improved goods and services. The results also suggest that informal enterprises with competitive formal interactions have a better understanding of the domestic market in which they operate and are able to adapt quickly to changing demands of their consumers through new, comparatively cheaper products that easily sell in local product markets. The evidence also supports the idea that sampled informal enterprises with formal partners target upscale product markets and are as a result, less likely to be product innovators themselves.

These results have several implications for innovation policy in SSA. There is an increasing application of the innovation systems framework to innovation policy in 
Africa. While the system framework provides useful understanding of how innovations can be enhanced, it must be adapted to reflect the African socio-economic realities (Kraemer-Mbula and Wamae, 2010c, p.31). This chapter provides empirical evidence reiterating the importance of integrating informal enterprises and their learning processes as key components of the innovation system in Africa.

Agencies such as the Department of Small Scale Enterprises (DSSE), the National Board for Small-Scale Industries (NBSSI) must work to support and reduce the financial constraints of informal enterprises through credit schemes. Various financial packages and privileges are available for formal institutions producing knowledge. While the current apprenticeship system, for example, may need some restructuring in terms of making it systematic, it seems fair for these policies to be extended to informal enterprises. The Council for Indigeneous Business Association (CIBA) must be revamped to promote, modernise and support indigeneous knowledge and technological learning processes through training programs to enhance basic financial and numeracy skills of informal workers. These new skills can complement available capabilities of enterprises to promote the innovation process. 


\section{REFERENCES}

Acemoglu, D. (1997). Training and Innovation in an Imperfect Labour Market. The Review of Economic Studies, 64(3):445-464.

Acemoglu, D. and Pischke, J.-S. (1998). Why Do Firms Train? Theory and Evidence. The Quarterly Journal of Economics, 113(1):79-119.

Aghion, P., Bloom, N., Blundell, R., Griffith, R., and Howitt, P. (2005). Competition and Innovation: an Inverted-U Relationship. The Quarterly Journal of Economics, 120(2):701-728.

Ayyagari, M., Demirgüç-Kunt, A., and Maksimovic, V. (2011). Firm innovation in emerging markets: The role of finance, governance, and competition. Journal of Financial and Quantitative Analysis, 46(6):1545-1580.

Barr, A. (1999). Do SMEs network for growth? Enterprise in Africa - Between poverty and growth, pages 121-131.

Bas, D. (1989). On-the-Job Training in Africa. International Labour Review, 128:485-496.

Becker, G. S. (1962). Investment in Human Capital: A Theoretical Analysis. Journal of Political Economy, 70(5):9-49.

Bell, M. and Albu, M. (1999). Knowledge Systems and Technological Dynamism in Industrial Clusters in Developing Countries. World Development, 27(9):1715-1734.

Benjamin, N. and Mbaye, A. A. (2015). Informality, Growth, and Development in Africa. In Monga, C. and Lin, J. Y., editors, The Oxford Handbook of Africa and Economics: Context and Concepts, chapter 33, pages 620-635. Oxford University Press, volume 1 edition.

Bull, C., Daniels, S., Kinyanjui, M., and Hazeltine, B. (2016). A Study of the Informal Metalworking Sector in Nairobi. In Kraemer-Mbula, E. and Wunsch-Vincent, S., editors, The Informal Economy in Developing Nations: Hidden Engine of Innovation?, pages 100-145. Cambridge University Press, Cambridge.

Charmes, J., Gault, F., and Wunsch-Vincent, S. (2016). Formulating an Agenda for the Measurement of Innovation in the Informal Economy. In Kraemer-Mbula, E. and Wunsch-Vincent, S., editors, The Informal Economy in Developing Nations: Hidden Engine of Innovation?, pages 336-370. Cambridge University Press, Cambridge. 
Chen, M. A. (2006). Rethinking the informal economy: Linkages with the formal economy and the formal regulatory environment. In Guha-Khasnobis, B., Kanbur, R., and Ostrom, E., editors, Linking the Formal and Informal Economy: Concepts and Policies, pages 75-92. Oxford University Press.

Classen, N., Carree, M., van Gils, A., and Peters, B. (2014). Innovation in family and non-family SMEs: An exploratory analysis. Small Business Economics, 42(3):595-6o9.

Cohen, W. M. and Levinthal, D. A. (1989). Innovation and Learning: The Two Faces of R \& D. The Economic Journal, 99(397):569-596.

Cohen, W. M. and Levinthal, D. A. (1990). Absorptive Capacity: A New Perspective on Learning and Innovation. Administrative Science Quarterly, 35(1):128-152.

Cozzens, S. and Sutz, J. (2014). Innovation in informal settings: reflections and proposals for a research agenda. Innovation and Development, 4(1):5-31.

Dawson, J. (1992). The Relevance of the Flexible Specialisation Paradigm for SmallScale Industrial Restructuring in Ghana. IDS Bulletin, 23(3):34-38.

de Beer, J., Armstrong, C., Schonwetter, T., and Oguamanam, C. (2014). Innovation and Intellectual Property: Collaborative Dynamics in Africa. Technical report, Rochester, NY.

de Beer, J., Fu, K., and Wunsch-Vincent, S. (2013). The informal economy, innovation and intellectual property - Concepts, metrics and policy considerations. World Intellectual Property Organization - Economics and Statistics Division Working Paper, Number 10. Retrieved from http://www.wipo.int/export/site.

Essegbey, G. O. and Awuni, S. (2016). Herbal Medicine in the Informal Sector of Ghana. In Kraemer-Mbula, E. and Wunsch-Vincent, S., editors, The Informal Economy in Developing Nations: Hidden Engine of Innovation?, pages 194-231. Cambridge University Press, Cambridge.

Frazer, G. (2006). Learning the master's trade: Apprenticeship and human capital in Ghana. Journal of Development Economics, 81(2):259-298.

Fu, X., Mohnen, P., and Zanello, G. (2015). Innovation, informality, and firms' growth in low-income countries. TMD working paper 72. TMCD, Oxford, UK.

Fu, X., Zanello, G., Owusu Essegbey, G., Hou, J., and Mohnen, P. (2014). Innovation in low income countries: A survey report. OMDC, Oxford, UK. Retrieved from https://www.gov.uk/dfid-research-outputs/innovation-inlow-income-countries-a-survey-report\#citation.

Gebreeyesus, M. and Mohnen, P. (2013). Innovation Performance and Embeddedness in Networks: Evidence from the Ethiopian Footwear Cluster. World Development, 41:302-316. 
Goedhuys, M. (2007). Learning, product innovation, and firm heterogeneity in developing countries; Evidence from Tanzania. Industrial and Corporate Change, 16(2):269292.

Guha-Khasnobis, B., Kanbur, R., and Ostrom, E. (2006). Beyond formality and informality. In Guha-Khasnobis, B., Kanbur, R., and Ostrom, E., editors, Linking the Formal and Informal Economy, pages 1-18. Oxford University Press, Oxford.

Hart, K. (2006). Bureaucratic form and the informal economy. In Guha-Khasnobis, B., Kanbur, R., and Ostrom, E., editors, Linking the Formal and Informal Economy, pages 21-35. Oxford University Press, Oxford.

Hausman, A. (2005). Innovativeness among small businesses: Theory and propositions for future research. Industrial Marketing Management, 34(8):773-782.

Heckman, J. (1979). Sample Selection Bias as a Specification Error. Econometrica, 47(1):153-161.

Kawooya, D. (2014). Informal-Formal Sector Interactions in Automotive Engineering, Kampala. In de Beer, J., Amstrong, C., Oguamanam, C., and Schonwetter, T., editors, Innovation $\mathcal{E}$ Intellectual Property: Collaborative Dynamics in Africa, chapter 3, pages 59-76. Published by UCT Press.

Konte, A. and Ndong, M. (2012). The informal ICT sector and innovation processes in Senegal. African Journal of Science, Technology, Innovation and Development, 4(3):61-97.

Kraemer-Mbula, E. (2016). Informal Manufacturing of Home and Personal Care Products in South Africa. In Kraemer-Mbula, E. and Wunsch-Vincent, S., editors, The Informal Economy in Developing Nations: Hidden Engine of Innovation?, pages 146-193. Cambridge University Press, Cambridge.

Kraemer-Mbula, E. and Wamae, W. (2010a). Adapting the Innovation Systems Framework to Sub-Saharan Africa. In Kraemer-Mbula, E. and Wamae, W., editors, Innovation and the Development Agenda, pages 65-90. OECD Publishing.

Kraemer-Mbula, E. and Wamae, W. (2010b). Innovation and the Development Agenda. OECD Publishing.

Kraemer-Mbula, E. and Wamae, W. (2010c). Key Issues for Innovation and Development. In Wamae, W. and Kraemer-Mbula, E., editors, Innovation and the Development Agenda, pages 29-38. OECD Publishing.

Kraemer-Mbula, E. and Wamae, W. (2010d). The Relevance of Innovation Systems to Developing Countries. In Kraemer-Mbula, E. and Wamae, W., editors, Innovation and the Development Agenda, pages 39-64. OECD Publishing. 
La Porta, R. and Shleifer, A. (2008). The Unofficial Economy and Economic Development. Brookings Papers on Economic Activity, 39(2 (Fall)):275-363.

Lall, S. (2000). Skills , Competitiveness and Policy in Developing Countries. Comparative and General Pharmacology, (46):1-29.

Legros, D. and Galia, F. (2011). Are innovation and R\&D the only sources of firms' knowledge that increase productivity? An empirical investigation of French manufacturing firms. Journal of Productivity Analysis, 38(2):167-181.

Lundvall, B.-Å. (1988). Innovation as an Interactive Process:From user-producer interaction to the national system of innovation. In Dosi, G., Freeman, C., Nelson, R., Silverberg, G., and Soete, L., editors, Technical change and economic theory, pages 349-369. Pinter Publishers Limited, London.

Mahemba, C. M. and Bruijn, E. J. D. (2003). Innovation Activities by Small and Medium-sized Manufacturing Enterprises in Tanzania. Creativity and Innovation Management, 12(3):162-173.

Mairesse, J. and Mohnen, P. (2002). Accounting for Innovation and Measuring Innovativeness: An Illustrative Framework and an Application. The American Economic Review, 92(2):226-230.

Malerba, F. (1992). Learning by Firms and Incremental Technical Change. The Economic Journal, 102(413):845-859.

McCormick, D. and Atieno, R. (2002). Linkages Between Small and Large Firms in the Kenyan Food Processing Sector, pages 223-248. Edward Elgar Publishing, Inc., Cheltenham, UK.

Mcdade, B. E. and Malecki, E. J. (1997). Entrepreneurial Networking: Industrial Estates in Ghana. Tijdschrift voor economische en sociale geografie, 88(3):262-272.

Mincer, J. (1993). Studies in Human Capital. E. Elgar.

Murphy, J. T. (2002). Networks, trust, and innovation in Tanzania's manufacturing sector. World Development, 30(4):591-619.

OECD and Eurostat (2005). Oslo Manual. Guidelines for collecting and interpreting innovation data. Organisation for Economic Co-operation and Development, Paris, 3rd edition.

Oyelaran-Oyeyinka, B. and Lal, K. (2006). Learning new technologies by small and medium enterprises in developing countries. Technovation, 26(2):220-231.

Robson, P. J. A., Haugh, H. M., and Obeng, B. A. (2009). Entrepreneurship and innovation in Ghana: Enterprising Africa. Small Business Economics, 32(3):331-350. 
Romijn, H. (2002). Small Enterprise Development in Developing Countries: Innovation or Acquisition of Technological Capability? In van Dijk, M. P. and Sandee, H., editors, Innovation and Small Enterprises in the Third World, chapter 2, pages 15-47. Edward Elgar Publishing, Inc., Cheltenham, UK.

Roodman, D. (2011). Fitting fully observed recursive mixed-process models with cmp. Stata Journal, 11(2):159-206.

Sindzingre, A. (2006). The relevance of the concepts of formality and informality: a theoretical appraisal. In Guha-Khasnobis, B., Kanbur, R., and Ostrom, E., editors, Linking the Formal and Informal Economy, pages 58-74. Oxford University Press, Oxford.

Sorescu, A. B., Chandy, R. K., and Prabhu, J. C. (2003). Sources and Financial Consequences of Radical Innovation: Insights from Pharmaceuticals. Journal of Marketing, $67(4): 82-102$.

Teal, F., Monk, C., and Sandefur, J. (2008). Does Doing an Apprenticeship Pay Off? Evidence from Ghana. Centre for the Study of African Economies Working Paper Series, Number o8. Retrieved from http://www.csae.ox.ac.uk/workingpapers/pdfs/2008-o8text.pdf.

van Dijk, M. P. (2002). Innovation and Small Enterprise Development Examples from Burkina Faso, Ghana and Zimbabwe. In van Dijk, M. P. and Sandee, H., editors, Innovation and Small Enterprises in the Third World, pages 123-140. Edward Elgar Publishing, Inc., Cheltenham, UK.

van Dijk, M. P. and Sandee, H. (2002). Innovation and Small Enterprise Development in Developing Countries. In van Dijk, M. P. and Sandee, H., editors, Innovation and Small Enterprises in the Third World, chapter One, pages 1-11. Edward Elgar Publishing, Inc., Cheltenham, UK.

Velenchik, A. D. (1995). Apprenticeship Contracts, Small Enterprises, and Credit Markets in Ghana. The World Bank Economic Review, 9(3):451-475. 


\section{APPENDIX}

\section{D.1：DEFINITION OF VARIABLES}

Product innovation: A binary variable taking the value of 1 if the enterprise introduced product innovation over the last 3 fiscal years and o if otherwise.

Performance of Innovation: A continuous variable indicating the log share of product innovations in real total sales per worker. It is constructed as the share of total sales in 2015 due to product innovations deflated using implicit deflators from United Nations System of Accounts with base year 2005.Then a logarithm of real total sales due to product innovation divided by the total number of workers in 2015 .

TPP innovation: A binary variable taking the value of 1 if the enterprise introduced either product or process innovations over the last 3 fiscal years and o if otherwise.

Real total sales_2013 (log):Constructed as the difference in the logarithm of deflated total sales of output in 2015 minus the logarithm of deflated total sales of output in 2013. Sales are deflated using implicit deflators from United Nations System of Accounts with base year 2005 .

Formal interaction: A binary variable taking the value of 1 if the enterprise had any form of relationship with registered enterprises over the last 3 fiscal years and o if otherwise.

Compete: A binary variable taking the value of 1 if the enterprise had a competitive relationship with registered enterprises over the last 3 fiscal years and o if otherwise.

Collaborate: A binary variable taking the value of 1 if the enterprise had a collaborative relationship with registered enterprises over the last 3 fiscal years and o if otherwise.

Apprenticeship (log): A continuous variable indicating the logarithm of the total number of apprentices the enterprise had in 2013 plus 1 . The addition of 1 was to avoid the drop of enterprises that do not train any apprentice.

Crime: A binary variable that takes value of 1 if the enterprise considered crime as a major obstacle to their business and o if otherwise.

Lack of access to finance: A binary variable that takes value of $I$ if the enterprise considers lack of finance as a major obstacle to their business and o if otherwise.

Number of innovations: A continuous variable indicating the total number of product innovations introduced by the enterprise over the last 3 fiscal years. 
Imitate formal sector: A binary variable that takes value of 1 if the enterprise imitates goods and services of registered enterprises and o if otherwise.

Firm marketing: A binary variable that takes value of 1 if the enterprise employs the services of a marketing agency and o if otherwise.

Family business: A binary variable that takes value of 1 if the enterprise is owned and operated by a family and o if otherwise.

Apprenticed owner: A binary variable that takes value of 1 if the owner of the enterprise is a former apprentice and o if otherwise.

City of enterprise: A dummy variable that takes value 1 if the enterprise is located in Accra and o if the enterprise is located in Tema.

Sector of firm: A dummy variable that takes value $I$ if the firm is engaged in manufacturing and o if firm is engaged in services. Services refers to retail services and non-retail services (other services).

Ownership: A dummy variable that takes value 1 if the firm is male owned and o if the firm is owned by a female.

Firm size: A categorical variable that takes value o if the firm is micro $(<5), 1$ if the firm small ( $>=5$ and $<10$ ), 2 if the firm is medium (10 and $<20$ ).

Zones: A categorical variable indicating the 17 zones in which enterprises were interviewed.

Formal: A dummy variable that takes value 1 if the enterprise would like to formalise and o otherwise.

Corruption: A binary variable that takes value of 1 if the enterprise considers corruption as a major obstacle to their business and o if otherwise.

Equipment: A binary variable that takes value 1 if the enterprise purchased new equipments in the last 3 fiscal years and o if otherwise.

Lack of access to electricity and water: A binary variable that takes value of 1 if the enterprise considers lack of electricity and water as a major obstacle to their business and $o$ if otherwise.

Total employment_2013 (log): A continuous variable indicating the logarithm total number of employees of the enterprise in 2013. 
Table D.1: Estimation outputs for formal interaction and apprenticeship

\begin{tabular}{lc}
\hline Estimation method & FIML \\
\hline Formal & Formal Interaction ${ }^{a}$ \\
& $0.520^{* * *}$ \\
Lack of access to electricity and water & $(0.121)$ \\
& 0.056 \\
Imitate formal sector & $(0.116)$ \\
& 0.255 \\
Real total sales_2013 $(\log )$ & $(0.195)$ \\
& 0.007 \\
Corruption & $(0.035)$ \\
& 0.278 \\
Crime & $(0.198)$ \\
& -0.037 \\
Lack of access to finance & $(0.125)$ \\
& $0.208^{*}$ \\
& $(0.122)$ \\
\hline
\end{tabular}

\begin{tabular}{|c|c|}
\hline & Apprenticeship \\
\hline \multirow[t]{2}{*}{ Ownership } & $0.050^{*}$ \\
\hline & (0.030) \\
\hline \multirow[t]{2}{*}{ Lack of access to finance } & 0.013 \\
\hline & $(0.032)$ \\
\hline \multirow[t]{2}{*}{ Equipment } & $0.132^{* * *}$ \\
\hline & $(0.045)$ \\
\hline \multirow[t]{2}{*}{ Total employment_2013 (log) } & $0.079^{* * *}$ \\
\hline & (0.026) \\
\hline \multirow[t]{2}{*}{ Formal } & $0.113^{* * *}$ \\
\hline & $(0.037)$ \\
\hline \multirow[t]{2}{*}{ Real total sales_2013 (log) } & 0.002 \\
\hline & $(0.007)$ \\
\hline \multirow[t]{2}{*}{ Family business } & 0.001 \\
\hline & (0.030) \\
\hline \multirow[t]{2}{*}{ Corruption } & -0.017 \\
\hline & (0.048) \\
\hline \multirow[t]{2}{*}{ Crime } & -0.043 \\
\hline & $(0.034)$ \\
\hline \multirow[t]{2}{*}{ Age (log) } & 0.011 \\
\hline & (0.020) \\
\hline \multirow[t]{2}{*}{ Apprenticed owner } & $0.175^{* * *}$ \\
\hline & $(0.040)$ \\
\hline $\mathrm{N}$ & 499 \\
\hline
\end{tabular}

All regressions include 22 zones, city and sector dummies.

${ }^{a}$ The reported estimates are probit regression coefficients. 


\subsection{CONCLUSION}

7 HE global production structure continuous to evolve across all economies. Technological change remains a major driver of this evolution. New waves of technologies, such as Artificial Intelligence (AI) and automation in the form of robotisation, promise to revolutionise the global production process even further. While technological progress has been key in transforming the so-called 'Asian Tigers', for instance, similar socio-economic transformation remains a mirage in sub-Saharan Africa (SSA).

Innovation and the innovation activities of firms may reveal the level of knowledge, technology and the potential for value creation in the wider economy. The emergence of new technologies and production processes, therefore, offer SSA economies and firms a window of opportunity to create value and keep up with the pace of technological progress through innovation activities. The role of open-minded innovation policies that help to position firms in SSA to benefit from these new technological changes cannot be overemphasised. Open-minded innovation policies have the potential to drive sustainable development, as well as a new social construction about informal enterprises. The policy process, however, can benefit from answers to four main questions. First, what is innovation in SSA? Second, what factors drive firm-level innovations? Third, what are the implications of innovations on economic indicators? And fourth, how can innovation policy influence the innovation process in SSA?

This thesis approached these questions with the notion that firm innovation activities drive employment creation and competitiveness. It, therefore, argued and studied in detail the innovations of firms in SSA, taking into account the economic role of informal enterprises. Informal enterprises and their activities in SSA deserve to be studied in their own right, because of their economic and social significance as well as the inherent persistence of the informal economy. The thesis provides empirical insights that contribute to the understanding of these critical questions from this view point. Above all, the thesis lays a foundation to motivate and guide future research. 
To summarise, this thesis specifically conducts empirical analyses of the relationship between product innovations and firm performance in SSA. Chapter two presents analysis of the impact of product innovations on total employment in Democratic Republic of Congo, Ghana, Tanzania, Uganda and Zambia. Since firms may endogenously self-select into whether to introduce product innovation or not, the analysis adapts the Dose Response Model where product innovation is considered to be endogenous in order to account for selection bias in the innovation process. The model also controls for heterogeneity in the intensity of product innovations as it varies across firms. Using data from the recent waves of the World Bank's Enterprise and the Innovation Follow-up Surveys, the main results reveal positive impact of product innovations on total employment, but only within specific intervals of product innovation intensities. The analysis also reveals that product innovations tend to have positive impact on both temporary employment and permanent employment. Based on these findings, the chapter proposes national and regional innovation policies that promote product innovations in firms. These innovation policies may, however, be complemented with other policies such as the ILO-WHO Social Protection Floor Initiative that seeks to promote minimum social security to all workers. The role of firms in developing and extending in-house social protection programmes to all manner of workers may be critical in this process.

There is a widespread notion that the competitive behaviours of informal enterprises in product markets negatively affect the performance of formal firms. Informality remain a typical feature of SSA economies, and informal enterprises continue to play significant roles both in terms of providing goods and services as well as employment, mainly to those at the bottom of the pyramid. Using firm-level survey data from Chapter two, Chapter three investigates the effect of informal competition on the performance of product innovations introduced by formal firms. The analysis applies an econometric approach at the first stage of estimation that localises the perception of informal competition thereby reducing subjective bias and possible bi-directional causality between informal competition and product innovations. At the second stage of estimation, the analysis applies Type II Tobit model in order to control for self and sample selection biases. The main results show that local informal competition has a negative effect on the performance of product innovations while industry informal competition has a positive effect on product innovation. Both local and industry levels of informal competition were, however, found to have no effect on the probability of introducing product innovations. Our analysis also reveals that firms with larger market share perform better in product markets that are highly informal. This result indicates that formal firms mitigate the poor performance of their product innovations by strategically collaborating with informal enterprises in order to enhance their market acceptance and sales of new innovative products.

While informal enterprises dominate economic activities in SSA, data on innovation activities of firms in SSA focus largely on formal enterprises. Using zones defined in the Ghana Informal Enterprise Survey (GIFS) of the World Bank, and conducting 
face-to-face interviews of 513 informal enterprises, Chapter four presents descriptive statistics of survey data collected on the innovation activities of informal enterprises in urban Ghana. The analysis reveals that informal enterprises do introduce innovations. These innovations, as found in formal enterprises as well, are not big swings, that is, not radical but incremental and often occur over several years. These incremental innovations, notwithstanding, are important to the survival of these enterprises.

Peculiar learning and knowledge sharing paths exist in the informal economy. While learning processes remain key drivers of innovation, empirical analysis of the role apprenticeship and formal interaction play in generating knowledge essential for innovation in informal enterprises remain missing. Based on the unique survey data presented in Chapter four, Chapter five examines the effects of apprenticeship and formal interactions on the innovation performance of informal enterprises in Ghana. The analysis reveals significant and positive effects of apprenticeship and formal interaction on the innovation performance of sampled informal enterprises. Decomposing formal interaction, the results indicate that enterprises with competitive formal interaction tend to have a strong positive effect on innovation performance while enterprises with collaborative formal interaction have strong negative effect. The results also show apprenticeship improves technological capabilities of enterprises leading to product innovation whereas competitive formal interaction provides essential domestic market signal that enhances the innovativeness and the performance of product innovations of enterprises. Our findings suggest apprenticeship and formal competitive interaction may thus be to informal enterprises' innovation activities what R\&D is evidenced to be for innovation in formal firms.

\subsection{POLICY RECOMMENDATIONS}

Policy in sub-Saharan Africa (SSA) tends to concentrate on generating growth that is heavily dependent on the export of raw materials rather than on improving the well-being of firms and citizens. There is the need for policy redirection towards making firms, both formal and informal, thrive through innovation activities rather than through the traditional obssession of primary goods export and formalisation. While product innovation stimulates total employment, it tends to generate more of temporary employment than permanent employment. Universal social security policies where all workers, irrespective of the place of work, have access to, and contribute voluntarily to pension schemes, for example, may be much effective in improving the growth process and conditions of citizens than the popular 'arm-chair' formalisation policies.

The new African Union Agenda 2063 and the 'Science, Technology and Innovation Strategy for Africa 2024 (STISA-2024)' both stress ST\&I and the welfare of its people as key enablers of Africa's transformation in the next 50 years. While these are steps 
in the right direction, there is the need also for policy realisation that informal activities do not happen in the shadow, and that informal enterprises matter as actors in Africa's innovation systems. Innovation policies in sub-Saharan Africa must, therefore, move beyond granting privilege to few registered firms to capturing innovations emerging in the so called 'marginalised' sectors as well as the promotion of interaction between enterprises in both the formal and informal sectors, for example. These policy redirections are key to achieving 'inclusive development' and a 'prosperous' sub-Saharan Africa.

\subsection{LIMITATIONS AND DIRECTIONS FOR FUTURE RESEARCH}

Though this thesis presents a perspective and a new empirical evidence on innovation activities in SSA, the analyses could be extended in several other ways.

The thesis focuses largely on the economic effects of product innovations. The analyses in Chapters 2 and 3, for instance, mainly consider product innovations using data from 5 SSA economies. While this is mainly due to the statistical measurement of other types of innovation and data, our analyses may have failed to capture the complexities and complete view of innovations. Future research could consider organisational and marketing innovations as well as extend the number of countries as more data become available.

The analysis in Chapter 2 only focuses on total employment with permanent employment and temporary employment differentiations. This is due to large missing observations in other differentiations of employment such as skilled versus unskilled, production versus non-production workers, and female versus male workers. The nature of the data used also poses issues of time inconsistency between employment outcomes and our innovation variables. As a result, the analysis failed to consider employment growth. Further research could extend the analysis in this chapter by using quality and comparable panel data. Recent empirical evidence also indicates that the impacts of product innovation and product innovation intensity on a firm's employment may differ over time and may depend on the life cycle of the firm (the so-called 'three-stage model'). Based on the nature of our data (cross-section), I could not examine the 'three-stage model.' A natural extension of the chapter would also be to examine the lag structure of the impact of firm-level innovation on firm-level employment outcomes in sub-Saharan Africa, with the availability of time series/panel data.

In Chapters 4 and 5, I provide evidence on innovation activities of informal enterprises. There is little theoretical evidence on how to integrate informal enterprises into the innovation systems framework, for instance. New research agenda could focus on this. Due to data limitations, Chapter 5 failed to consider contract types and forms of apprenticeship. It will be insighful for future research to consider the effects of spe- 
cific contracts of apprentices on the innovation activities of enterprises. Evidence also exists indicating enterprises have different degrees of interaction. Further research exploring how variations in the degree of formal interactions affect innovation activities of informal enterprises could be insightful. Questions also remain regarding whether apprenticeship and formal interactions have any effect on other types of innovation such as marketing and organisational. Chapter 5 focused only on product innovation. I suggest analyses regarding other types of innovation as areas for future research.

\subsection{FINAL REFLECTION}

Innovations, particularly firm-level innovations in sub-Saharan Africa, have received little attention in development economics. This thesis sheds light and contributes towards filling this gap by empirically analysing innovation activities of firms in SSA. Due to the peculiar learning and knowledge sharing paths, economic arrangement, and incentives, the nature of innovation and its economic implications may differ. Simply extending evidence from other regions may provide inaccurate understanding of the relationship between innovation and employment, for instance, in SSA. Since innovation policy has also gained some attention on the continent in recent years, it is critical to understand the specific contexts of innovations in order to devise appropriate and effective policy.

Firm innovation activities thereby offer prospects for economic progress through competitiveness, employment creation as well as poverty reduction. Firms in SSA create value and secure their survival through innovations. If this perspective as presented in this thesis is accepted, then it can be argued that the option to engage in economic activities irrespective of registration status, for example, offers a unique opportunity to resolve some of the key socio-economic challenges the continent faces. Policy realisation of this matters for the economic advancement sought in sub-Saharan Africa. 



\section{VALORISATION ADDENDUM}

In accordance with article 23.5 of the 'Regulation governing the attainment of doctoral degrees at Maastricht University' decreed by resolution of the Board of Deans, dated 3 July 2013, this chapter on addendum discusses the valorization opportunities of this doctoral thesis.

Recent decades have seen a rise in optimism with regards to the sustainable economic prospects of sub-Saharan Africa through innovation. This thesis primarily focuses on the empirical analyses of innovation activities of firms in sub-Saharan Africa, with specific emphasis on the innovation process, the market performance of new products and the labour market impact of new products. The novelty of this thesis comes from the duality perspective, where it departs from mainstream views of development economics by considering innovations in both formal and informal firms.

The thesis provides new insights for governments, continental and regional organisations, stakeholders as well as researchers. The results (Chapters 2, 3, 4 and 5) indicate the need for holistic rather than partial innovation policy perspective. Chapter 2 highlights the need for governments to understand the direct and indirect mechanisms through which innovations can affect total employment. As the creation of quality employment avenues, particularly for the youth, gain policy concern in subSaharan Africa, the evidence presented in this chapter indicates to governments the need for complementary labour market policies, for example, in addition to innovation policies. Chapter 3 brings to fore the critical importance of informal enterprises in product markets for registered firms. Chapters 4 and 5 further highlight the innovation activities of informal enterprises, using survey data from urban Ghana. Survey activities undertaken and the data collected for Chapters 4 and 5 add to this field of research. Meeting owners and caretakers of informal enterprises and interacting with them about their economic and innovation activities provided the research team deeper insight and understanding of the informal economy. Background information about the objectives of the survey provided an atmosphere of learning, interest and knowledge exchange. This thesis therefore helps to correct the prejudice that informal activities are hidden and that informal enterprises are not innovative. 
This thesis will be available to governments, researchers and policymakers. The findings, related knowledge and justifications from this thesis have already been presented at conferences and workshops during the course of this research. For instance, Chapter 2 was presented at the 19th Annual Conference on Global Economic Analysis, World Bank Group (2016, Washington D.C, USA); HESPI Conference on IGAD Economies (2016, Addis Ababa, Ethiopia). A draft of this chapter has been cited by the International Labour Office (ILO) in the World Employment Social Outlook 2017, on 'Sustainable enterprises and jobs: Formal enterprises and decent work.' Chapter 3 was presented at the Informality and Development conference in Honour of Elinor Ostrom, Indiana University (2016, Bloomington-Indiana, USA); UNU-MERIT Research Theme 1 Meeting on Economics of Knowledge and Innovation (2016, Maastricht, The Netherlands). Findings from the research in Chapters 4 and 5 were also presented to both academic and non-academic audiences at the 12th Globelics International Ph.D. Academy on Innovation and Economic Development, Research Center for Knowledge, Science, Technology and Innovation Studies (TaSTI), University of Tampere (2017, Tampere, Finland); 3rd Africalics International Conference on Emerging Innovation Systems for Sustainable Industrial Development in Africa (2017, Oran, Algeria). Discussions and debates of results, in these conferences and workshops were positive indicating the growing research and policy attention, and relevance of the issues examined in this thesis.

Some evidence in the literature indicates the informal economy in sub-Saharan Africa is here to stay and suppressing informal activities through laws and 'formalisation' policies in general do not work. Overall, this thesis contributes to the debate on formalisation, and our results indicate the need for novel policy redirection from African governments to promote and enhance the vibrant entrepreneurial spirit and environment in which learning processes incubate knowledge for innovation in their respective economies, particularly in informal enterprises. Participatory and openminded policies aimed at understanding and promoting co-creation and interactions between formal and informal enterprises, for example, may help to nurture and capture fully the value of learning processes for innovation. In this vein, one practical policy action will be to expand the African Science Technology and Innovation Indicators (ASTII) initiative to include informal enterprises. Data sampling and analysis procedures employed in this thesis are available and could be adopted in this process. Researchers must make further effort to observe, understand and promote informal enterprises and their 'hidden' innovation activities without prejudice. Given the current realities of persistent poverty and rising demographic pressure in sub-Saharan Africa, informal enterprises and their activities may provide the best chance to drive, and achieve sustainable and inclusive development.

One way forward, in my view, is for African countries to undertake a major, nationallevel research project addressing questions raised in this thesis. 
Elvis Korku Avenyo obtained both his Bachelor of Arts (B.A) and Master of Philosophy (M. Phil.) degrees in Economics from the University of Cape Coast, Ghana. In 2011, he attended the African Economic Research Consortium's Joint Facility for Electives: Collaborative Masters Programme (CMAP) in Economics, specialising in econometrics and monetary economics. He has worked as a senior consultant at GlobalStandards Consulting, Accra, Ghana, and as a research intern at the International Labour Organization (ILO), Geneva, and also at the Council for Scientific and Industrial Research-Science and Technology Policy Research Institute (CSIR-STEPRI), Accra. He has worked as a course tutor at Maastricht University's Faculty of Arts and Social Sciences (FaSoS), Maastricht Graduate School of Governance (MGSOG) and the University of Cape Coast. At United Nations University (UNU)-MERIT, he served as a research assistant working on the United Nations Educational, Scientific and Cultural Organization's UNESCO Science Report: Towards 2030, published in 2015. He is a member of the Royal Economic Society, Development Studies Association, Young Scholars Initiative (YSI) of the Institute for New Economic Thinking (INET), Global Network for Economics of Learning, Innovation, and Competence Building Systems (Globelics), African Network for Economics of Learning, Innovation, and Competence Building Systems (AfricaLics), and the New and Emerging Researchers Group (NERG) of the Open African Innovation Research (Open AIR) Network. He has been awarded the Global Excellence and Stature (GES) Fellowship by the University of Johannesburg (UJ), and the Open AIR's Queen Elizabeth's Scholars award, for postdoctoral research at the UJ.

His specialisation focuses on econometrics of firm innovations, informal sector innovations, performance of Small and Medium-Sized Enterprises (SMEs), technologies, economic development, impact evaluation and developing countries. 


\section{UNU-MERIT/MGSoG Dissertation Series}

2018

Elvis Korku Avenyo

Innovations and Firm Performance in sub-Saharan Africa:

Empirical Analyses

UNU-MERIT/MGSoG Dissertation

Series № 202

\section{Ni Zhen}

Employment Dynamics, Firm

Performance and Innovation

Persistence in the Context of

Differentiated Innovation Types:

Evidence from Luxembourg

UNU-MERIT/MGSoG Dissertation

Series № 201

\section{Caroline Wehner}

Too Scared to Achieve:

The Relation Between Neuroticism,

Conscientiousness and Socioeconomic

Outcomes

UNU-MERIT/MGSoG Dissertation

Series № 200

\section{Stefania Innocenti}

On Institutional Persistence

UNU-MERIT/MGSoG Dissertation Series № 199

\section{Hassen Abda Wako}

Economic Globalization, Institutions and Development: Essays on Aid, Foreign Direct Investment and Trade UNU-MERIT/MGSoG Dissertation Series № 198
2017

Hans-Erik Edsand

Winds of Change

UNU-MERIT/MGSoG Dissertation

Series № 197

\section{Ana Patricia Silva Vara}

Redressing the Gender Gap

UNU-MERIT/MGSoG Dissertation

Series № 196

\section{Andrés Iván Mideros Mora}

Essays on the Economic Effects of Noncontributory Social Protection

UNU-MERIT/MGSoG Dissertation

Series № 195

\section{Tobias Broich}

New Actors in the Global Economy UNU-MERIT/MGSoG Dissertation Series № 194

\section{Bernard Nikaj}

From No-government to E-government UNU-MERIT/MGSoG Dissertation Series № 193

\section{Ali Safarnejad}

Prioritizing the HIV Response

UNU-MERIT/MGSoG Dissertation

Series № 192 


\section{Clovis Freire}

Diversification and Structural

Economic Dynamics

UNU-MERIT/MGSoG Dissertation

Series № 191

\section{Michael Verba}

Innovation and Knowledge Dynamics:

Essays on the Knowledge Economy

UNU-MERIT/MGSoG Dissertation

Series № 190

\section{Pui Hang Wong}

The Hearts and Minds in Conflict and

Peace: The Economics of

Counterinsurgency and the Psychology of Reconstruction

UNU-MERIT/MGSoG Dissertation

Series № 189

\section{Brenda Yamba}

Schooling Despite All Odds: Evidence from Lesotho on Female Child Carers who Stayed in School

UNU-MERIT/MGSoG Dissertation Series № 188

\section{Sheng Zhong}

Moving towards An Energy Efficient Future: Essays on Energy Efficiency, Technology and Development UNU-MERIT/MGSoG Dissertation Series № 187

\section{Julieta Marotta}

Access to Justice and Legal

Empowerment of Victims of Domestic

Violence through Legal Organizations in the City of Buenos Aires: A

Qualitative Empirical Legal Study

UNU-MERIT/MGSoG Dissertation

Series, № 186

\section{Andrea Franco-Correa}

On the Measurement of

Multidimensional Poverty as a Policy Tool: Empirical Applications to Chile, Colombia, Ecuador and Peru UNU-MERIT/MGSoG Dissertation Series, № 185

\section{6}

\section{YesufAwel}

Insurance for Growth: Empirical

Essays on Insurance Demand and Impacts in Africa

UNU-MERIT Dissertation Series, № 108

\section{Tigist Mekonnen Melesse}

Grow More Food using Fewer Resources: Agricultural Technology Adoption and Innovation Practices for Inclusive and Sustainable

Development

UNU-MERIT Dissertation Series, № 107

\section{Eleni Yitbarek}

Getting Ahead or left Behind? Essays on Poverty Dynamics and Social Mobility in Africa UNU-MERIT Dissertation Series, № 106 


\section{Thuy Dieu Nguyen}

Firm-Level Theory and Evidence of

Corruption

UNU-MERIT Dissertation Series, № 105

\section{Raquel Tsukada Lehman}

Essays on Household Production with

Labor-Saving Technology

UNU-MERIT Dissertation Series, № 104

\section{Eva Barteková}

Multi-Problem Challenges for a

Renewable Future: Empirical Studies on Competitive Disadvantages from

Electricity Price Differentials and

Mineral Supply Risk in an Open

Economy

UNU-MERIT Dissertation Series, № 103

\section{Jocelyn Olivari}

Entrepreneurial Traits and Innovation:

Evidence from Chile

UNU-MERIT Dissertation Series, № 102

\section{Muhammad Shafique}

Essays on the role of knowledge, RED, and Technology-based Firms in the

Evolution of Socio-techno-economic

System

UNU-MERIT Dissertation Series, № 101

\section{Serdar Türkeli}

Governance of Innovation Policy:

Empirical Studies on Applied Political

Economy by Multi-Methods Analysis

UNU-MERIT Dissertation Series,

№ 100

\section{Ayokunu Adedokun}

Pathways to Sustainable Peace

building in Divided Societies: Lessons

and Experiences from Mozambique

MGSoG Dissertation Series, № 75

\section{Luiz RothierBautzer}

Organizing Concurrent Engineering

through ICT Platforms

Blueprinting Product Lifecycle

Management Platforms across

Disciplinary Agencies

MGSoG Dissertation Series, № 74

\section{Natalia Popova}

Migration in the Periphery of the

European Union:

Determinants of Successful and

Sustainable Labour Market Integration of Return Migrants in Albania, Egypt, Moldova and Tunisia

MGSoG Dissertations Series, № 73

\section{Richard A. Martina}

Uncertainty and Resource Constraint in the Small Island Developing States: Essays in Entrepreneurial Cognition MGSoG Dissertations Series, № 72 


\section{Cécile Cherrier}

The Expansion of Basic Social

Protection in Low-income Countries:

An Analysis of Foreign Aid Actors'

Role in the Emergence of Social

Transfers in Sub-Saharan Africa

MGSoG Dissertations series, № 71

\section{Paul Caldron}

The Tacit Bargain in Short-Term

Medical Missions: Why U.S.

physicians go and what it costs

MGSoG Dissertation Series, № 70

\section{Mahmut Kobal}

Customs \& Excellence: A Comparative

Approach on Administrative and

Regulatory Compliance Perspectives of the EU-Turkey Customs Union

MGSoG Dissertation Series, № 69

\section{Craig Loschmann}

Essays on Conflict-related Migration and Development in the Case of

Afghanistan

MGSoG Dissertations Series, № 68

\section{Andrea Milan}

Rural Livelihoods, Location and

Vulnerable Environments: Approaches to Migration in Mountain areas of

Latin America

MGSoG Dissertation Series, № 67

\section{Farida Lada}

On Guarding the Welfare of Clinical

Trial Subjects While Promoting Novel

Drug Innovation

A Game Theoretical Approach

MGSoG Dissertation Series, № 66
2015

\section{Hibret Belete Maemir}

Dissecting Aggregate Productivity:

International Integration and Growth with Heterogeneous Firms

UNU-MERIT Dissertation Series, № 96

\section{Giorgio Triulzi}

Looking for the Right Path: Technology Dynamics, Inventive Strategies and Catching-up in the Semiconductor Industry

UNU-MERIT Dissertation Series, № 95

\section{Abdul Baseer Qazi \\ Knowledge flows and networks in the ICT sector: The case of Pakistan UNU-MERIT Dissertation Series, № 94}

\section{Ajay Thutupalli}

Technology Paradigm Shifts in Agriculture: Drivers of Sustainability and Catch up

UNU-MERIT Dissertation Series, № 93

\section{Eduardo Urias}

Improving access to HIVIAIDS treatment in Brazil: When are Compulsory Licenses effective in Price Negotiations?

UNU-MERIT Dissertation Series, № 92 


\section{Francesca Guadagno}

Why have so few Countries

Industrialised?

UNU-MERIT Dissertation Series, № 91

\section{Daniel Opolot}

The Evolution of Beliefs and Strategic

Behaviour

UNU-MERIT Dissertation Series, № 90

\section{Alejandro Lavopa \\ Structural Transformation and \\ Economic Development: Can \\ Development Traps be Avoided \\ UNU-MERIT Dissertation Series, № 89}

\section{Jinjin Zhao}

Urban water management reform: The

Case of China

UNU-MERIT Dissertation Series, № 88

\section{Simona Vezzoli}

Borders, Independence and Postcolonial Ties: the Role of the State in Caribbean Migration MGSoG Dissertation Series, № 65

\section{Silvia Consuelo Gómez Soler}

Civil Conflict and Education: How

Does Exposure to Civil Conflict Affect

Human Capital Accumulation?

Evidence from Standardized Exit

Exams in Colombia

MGSoG Dissertation Series, № 64

\section{Paula Nagler}

Occupational Choice in the Developing

World

MGSoG Dissertation Series, № 63

\section{Jasmin Kientzel}

Determinants of Professional

Commitment to Environmental

Sustainability

MGSoG Dissertation Series, № 62

\section{Mehmet GüneyCelbiş}

Regional Policies: Convergence, Trade, and the Allocation of Public Capital

MGSoG Dissertation Series, № 61

\section{Florian Henning}

Living Up to Standard:

Interoperability Governance and

Standards Adoption in Government

Information Networks

MGSoG Dissertation Series, № 60

\section{Niels P. Groen}

The Never-Ending Project

Understanding E-Government Project

Escalation

MGSoG Dissertation Series, № 59

\section{Derek Copp}

Teacher-Based Reactivity to Provincial

Large-scale Assessment in Canada

MGSoG Dissertation Series, № 58

\section{Michaella Vanore}

Family-Member Migration and the

Psychosocial Health Outcomes of

Children in Moldova and Georgia

MGSoG Dissertation Series, № 57 


\section{Sonja Fransen}

The Economic and Social Effects of Remittances and Return Migration in Conflict-Affected Areas: The Case of Burundi

MGSoG Dissertation Series, № 56

\section{Ibrahim Khalil Conteh}

The Impact of Floods on Primary

School Education in Zambia

MGSoG Dissertation Series, № 55

\section{Richard Bluhm}

Growth Dynamics and Development

Essays in Applied Econometrics and

Political Economy

MGSoG Dissertation Series, № 54

\section{Nevena P. Zhelyazkova}

Work-Family Reconciliation and Use of Parental Leave in Luxembourg:

Empirical Analysis of Administrative Records

MGSoG Dissertation Series, № 53

\section{4}

\section{Dirk Crass}

The Impact of Brands on Innovation and Firm Performance: Empirical Evidence from Germany UNU-MERIT Dissertation Series, № 87

\section{Samyukta Bhupatiraju}

The Geographic Dimensions of Growth and Development UNU-MERIT Dissertation Series, № 86

\section{François Lafond}

TheEvolution of Knowledge Systems UNU-MERIT Dissertation Series, № 85

\section{Annalisa Primi}

Promoting Innovation in Latin America: What Countries Have Learned (and What They Have Not) in Designing and Implementing Innovation and Intellectual Property Policies

UNU-MERIT Dissertation Series, № 84

\section{Fatoumata Lamarana Diallo}

Evaluation of Meal and Deworming Programs for Primary Schools in Rural Senegal

UNU-MERIT Dissertation Series, № 83

\section{Sachin Kumar Badkas}

Metachoice and Metadata: Innovating with Environmental Policy Analysis in Europe

MGSoG Dissertation Series, № 52

\section{Irina S. Burlacu}

An Evaluation of Tax-Benefit Systems Impact on the Welfare of Frontier Worker:

The Case of Luxembourg and Belgium MGSoG Dissertation Series, № 51

\section{ÖzgeBilgili}

Simultaneity in Transnational Migration Research: Links Between Migrants' Host and Home Country Orientation MGSoG Dissertation Series, № 50 


\section{Yulia Privalova Krieger}

Reshaping the Big Agenda:

Transnational Politics and Domestic

ResistanceFinancial crisis and social

protection reform in Bosnia and

Herzegovina

MGSoG Dissertation Series, № 49

\section{Marieke van Houte}

Moving Back or Moving Forward?

Return migration after Conflict

MGSoG Dissertation Series, № 48

\section{Oxana Slobozhan}

Global Governance in the Management of Natural Resources: The Case of the Extractive Industries Transparency Initiative (EITI)

MGSoG Dissertation Series, № 47

\section{Luis Bernardo Mejia Guinand}

The Changing Role of the Central

Planning Offices in Latin America: A

Comparative Historical Analysis

Perspective (1950-2013)

MGSoG Dissertation Series, № 46

\section{Cheng Boon Ong}

Ethnic Segregation in Housing,

Schools and Neighbourhoods in the

Netherlands

MGSoG Dissertation Series, № 45

\section{Luciana V. Cingolani}

Bureaucracies for Development:

Oxymoron or Reality? Studies on State

Capacity in Challenging Governance

Contexts

MGSoG Dissertation Series, № 44

\section{Carlos Cadena Gaitán}

Green Politics in Latin American

Cities - Sustainable Transport Agendas

MGSoG Dissertation Series, № 43

\section{Katie Kuschminder}

Female Return Migration and

Reintegration Strategies in Ethiopia

MGSoG Dissertation Series, № 42

\section{Metka Hercog}

Highly-Skilled Migration and New

Destination Countries

MGSoG Dissertation Series, № 41

\section{Margaret Agaba Rugadya}

Can Remittances Influence the Tenure

and Quality of Housing in Uganda?

MGSoG Dissertation Series, № 40

\section{IlireAgimi}

New Governance Under Limited

Statehood: The Case of Local

Government Reform in Kosovo

MGSoG Dissertation Series, № 39

2013

\author{
Anant Kamath \\ Information Sharing through Informal \\ Interaction in Low-Tech Clusters \\ UNU-MERIT Dissertation Series, \\ № 82
}




\section{Flavia Pereira de Carvalho}

What we talk about when we talk about

Brazilian Multinationals: An

Investigation on Brazilian FDI,

Economic Structure, Innovation and

the Relationship between them

UNU-MERIT Dissertation Series, № 81

\section{Jun Hou}

Complementarity in Innovation and

Development: A Cross-country

Comparison

UNU-MERIT Dissertation Series, № 80

\section{Rufin Baghana}

Impacts of Government Incentives to $R \mathcal{E}$, Innovation and Productivity:

A Microeconometric Analysis of the

Québec Case

UNU-MERIT Dissertation Series, № 79

\section{Lilia I. Stubrin}

High-Tech Activities in Emerging

Countries: A Network perspective on the Argentinean Biotech Activity

UNU-MERIT/MGSoG Dissertation

Series, № 78

\section{Kristine Farla}

Empirical Studies on Institutions, Policies and Economic Development MGSoG Dissertation Series, № 38

\section{Marina Petrovic}

Social Assistance and Activation in the Pursuit of Happiness: Shedding New

Light on Old Policy Solutions to Social Exclusion

MGSoG Dissertation Series, № 37

\section{Laura Torvinen}

Assessing Governance Assessments:

The Case of Mozambique: Governance

Assessments in the Context of Aid

Effectiveness Discourse

MGSoG Dissertation Series, № 36

\section{Biniam Egu Bedasso}

Institutional Change in the Long

Shadow of Elite: Essays on

Institutions, Human Capital and

Ethnicity in Developing Countries

MGSoG Dissertation Series, № 35

\section{Sepideh Yousefzadeh FaalDeghati}

Childhoods Embargoed: Constructing

and Reconstructing Multidimensional

Child Poverty in Iran 1984-2009

MGSoG Dissertation Series, № 34

\section{Robert Bauchmüller}

Investing in Early Childhood Care and

Education: The Impact of Quality on

Inequality

MGSoG Dissertation Series, № 33

\section{Martin Rehm}

Unified Yet Separated: Empirical

Study on the Impact of Hierarchical

Positions within Communities of

Learning

MGSoG Dissertation Series, № 32 


\section{Abdul Waheed}

Innovation Determinants and

Innovation as a Determinant: Evidence

from Developing Countries

UNU-MERIT Dissertation Series,

№ 77

\section{Bilal Mirza}

Energy Poverty and Rural Energy

Markets in Pakistan

UNU-MERIT Dissertation Series, № 76

\section{Benjamin Engelstätter}

Enterprise Software and Video Games:

An Empirical Analysis

UNU-MERIT Dissertation Series, № 75

\section{Fulvia Farinelli}

Natural Resources, Innovation and

Export Growth: The Wine Industry in

Chili and Argentina

UNU-MERIT Dissertation Series

\section{Rodolfo Lauterbach}

Innovation in Manufacturing: From

Product Variety and Labor

Productivity Growth to Economic

Development in Chile

UNU-MERIT Dissertation Series

\section{Kirsten Wiebe}

Quantitative Assessment of

Sustainable Development and Growth

in Sub-Saharan Africa

UNU-MERIT Dissertation Series, № 74

\section{Julio Miguel Rosa}

Organizational Strategies, Firms'

Performance and Spatial Spillovers:

The Canadian Case in Research and

Development.

UNU-MERIT Dissertation Series, № 73

Johannes Wilhelmus Marie Boels

Joseph Schumpeter, Honderd Jaar

Economische Ontwikkeling: Een

Historisch-theoretische Beschouwing.

UNU-MERIT Dissertation Series

\section{Dorcas Mbuvi}

Utility Reforms and Performance of the

Urban Water Sector in Africa

MGSoG Dissertation Series, № 31

\section{Lina Salanauskaite}

Distributional Impacts of Public

Policies: Essays in Ex-Ante and Ex-

Post Evaluation

MGSoG Dissertation Series, № 30

\section{Esther Schüring}

To Condition or not - is that the

Question?

An Analysis of the Effectiveness of Ex-

Ante and Ex-Post Conditionality in

Social Cash Transfer Programs

MGSoG Dissertation Series, № 29

\section{Joe Abah}

Strong Organisations in Weak States: Atypical Public Sector Performance in Dysfunctional Environments

MGSoG Dissertation Series, № 28 


\section{Zina Samih Nimeh}

Social Citizenship Rights: Inequality and Exclusion

MGSoG Dissertation Series, № 27

2011

\section{Daniel Vertesy}

Interrupted Innovation: Emerging

Economies in the Structure of the

Global Aerospace Industry

UNU-MERIT Dissertation Series, № 72

\section{Tina Saebi}

Successfully Managing Alliance

Portfolios: AnAlliance Capability View UNU-MERIT Dissertation Series, № 71

\section{Nora Engel}

Tuberculosis in India: A Case of

Innovation and Control

UNU-MERIT/MGSoG Dissertation

Series, № 70

\section{Evans Mupela}

Connectivity and growth in Sub-

Saharan Africa: The Role of

Communication Satellites

UNU-MERIT Dissertation Series, № 69

\section{Nantawan Kwanjai}

Cross Cultural Intelligence amid Intricate Cultural Webs: A Tale of the UnDutchables in the Land of 1002 Smiles

UNU-MERIT Dissertation Series, № 68

\section{Lina Sonne}

Innovation in Finance to Finance Innovation: Supporting Pro-poor Entrepreneur-based Innovation UNU-MERIT Dissertation Series, № 67

\section{Lenka Eisenhamerová}

Legitimacy of 'Humanitarian Military Intervention'

MGSoG Dissertation Series, № 26

\section{Sonila Tomini}

Informal Payments for Health Care Services in Albania

MGSoG Dissertation Series, № 25

\section{Jinjing Li}

Dynamic Microsimulation in Public Policy Evaluation

MGSoG Dissertation Series, № 24

\section{Aziz Atamanov}

Rural Nonfarm Employment and International Migration as Alternatives to Agricultural Employment: The Case of Kyrgyzstan MGSoG Dissertation Series, № 23

\section{Frieda Vandeninden}

Poverty Alleviation: Aid and Social Pensions

MGSoG Dissertation Series, № 22

\section{Juliana Nyasha Tirivayi}

The Welfare Effects of Integrating AIDS Treatment with Food Transfers: Evidence from Zambia

MGSoG Dissertation Series, № 21 
AgnieskaEwa Sowa

Who's Left Behind? Social Dimensions

of Health Transition and Utilization of

Medical Care in Poland

MGSoG Dissertation Series, № 20

\section{Emmanaouil Sfakianakis}

The Role of Private Actors in the

Provision of Public Goods with

Applications to Infrastructure and

Financial Stability

MGSoG Dissertation Series, № 19

\section{Siu Hing Lo}

White Collars Green Sleeves: An Inter-

organizational Comparison of

Determinants of Energy-Related

Behaviors among Office Workers

MGSoG Dissertation Series, № 18

\section{Treena $\mathbf{W u}$}

Constraints to Human Capital

Investment in Developing Countries:

Using the Asian Financial Crisis in

Indonesia as a Natural Experiment

MGSoG Dissertation Series, № 17

\section{Henry Espinoza Peña}

Impact Evaluation of a Job-Training

Programme for Disadvantaged Youths:

The Case of Projoven

MGSoG Dissertation Series, № 16
2010

Fernando Santiago

Human Resources Management

Practices and Learning for Innovation in Developing Countries:

Pharmaceutical Firms in Mexico

UNU-MERIT Dissertation Series,

№ 66

\section{Zakaria Babutsidze}

Essays on Economies with

Heterogeneous Interacting Consumers

UNU-MERIT Dissertation Series,

№ 65

\section{Bertha Vallejo}

Learning and Innovation Under

Changing Market Conditions: The

Auto Parts Industry in Mexico

UNU-MERIT Dissertation Series,

№ 64

\section{Donatus Ayitey}

Technical Change, Competitiveness

and Poverty Reduction: A Study of the

Ghanaian Apparel Industry

UNU-MERIT Dissertation Series, № 63

\section{Sergey Filippov}

Multinational Subsidiary Evolution:

Corporate Change in New EU Member

States

UNU-MERIT Dissertation Series, № 62 


\section{Asel Doranova}

Technology Transfer and Learning under the Kyoto Regime: Exploring the Technological Impact of CDM Projects in Developing Countries

UNU-MERIT Dissertation Series, № 61

\section{Florian Tomini}

Between Family and Friend:

Understanding the Interdependency of Private Transfers

MGSoG Dissertation Series, № 15

\section{Michał Polalowski}

The Institutional Transformation of

Social Policy in East Central Europe:

Poland and Hungary in Comparative and Historical Perspective

MGSoG Dissertation Series, № 14

\section{Maha Ahmed}

Defining, Measuring and Addressing Vulnerability: The Case of Post

Conflict Environments

MGSoG Dissertation Series, № 13

\section{Pascal Beckers}

Local Space and Economic Success:

The Role of Spatial Segregation of

Migrants in the Netherlands

MGSoG Dissertation Series, № 12

\section{Victor Cebotari}

Conflicting Demands in Ethnically

Diverse Societies: Ethno political

Contention and Identity Values in

Europe

MGSoG Dissertation Series, № 11

\section{Dennis Gyllensporre}

Competing and Complementary

Perspectives on the EU as a Crisis

Management Actor:

An Examination of the Common

Security and Defence Policy through

the Lenses of Idealism and Realism

MGSoG Dissertation Series, № 10

\section{Judit Vall Castello}

Business Cycle and Policy Effects on Labour Market Transitions of Older and Disabled Workers in Spain

MGSoG Dissertation Series, № 9

\section{Keetie Roelen}

False Positives or Hidden Dimensions:

The Definition and Measurement of

Child Poverty

MGSoG Dissertation Series, № 8

\section{Denisa Maria Sologon}

Earning Dynamics in Europe

MGSoG Dissertation Series, № 7

\section{Melissa Siegel}

Money and Mobility: Migration and

Remittances

MGSoG Dissertation Series, № 6

Jessica S. Hagen-Zanker

Modest Expectations: Causes and

Effects of Migration on Migrant

Households inSource Countries

MGSoG Dissertation Series, № 5 


\section{Alexis Habiyaremye}

From Primary Commodity Dependence to Diversification and Growth:

Absorptive Capacity and Technological Catch Up in Botswana and Mauritius. UNU-MERIT Dissertation Series, № 60

\section{Yoseph Getachew}

The Role of Public Capital in Economic Development

UNU-MERIT Dissertation Series, № 59

\section{Sandra Leitner}

Embodied Technological Change and Patterns of Investment in Austrian Manufacturing UNU-MERIT Dissertation Series, № 58

\section{SemihAkçomak}

The Impact of Social Capital on Economic and Social Outcomes UNU-MERIT Dissertation Series, № 57

\section{Abraham Garcia}

The Role of Demand in Technical Change

UNU-MERIT Dissertation Series, № 56

\section{Saurabh Arora}

Coherence in Socio-technical Systems: A Network Perspective on the Innovation Process UNU-MERIT Dissertation Series, № 55
Human Development and Autonomy in Project Aid: Experiences from four bilateral projects in Nicaragua and $\mathrm{El}$ Salvador

MGSoG Dissertation Series, № 4

\section{Christiane Arndt}

Governance Indicators

MGSoG Dissertation Series, № 3

\section{Britta Augsburg}

Microfinance: Greater Good or Lesser Evil?

MGSoG Dissertation Series, № 2

2008

\section{Rutger Daems}

Medicines for the Developing World UNU-MERIT Dissertation Series, № 54

\section{Johannes Hanel}

Assessing Induced Technology:

Sombart's Understanding of Technical

Change in the History of Economics

UNU-MERIT Dissertation Series, № 53

\section{Rifka Weehuizen}

Mental Capital: the Economic

Significance of Mental Health

UNU-MERIT Dissertation Series, № 52 


\section{Danielle Cloodt}

The Relationship between RED

Partnership Formation, Social

Embeddedness and Innovative

Performance

UNU-MERIT Dissertation Series, № 51

\section{Sabine Fuss}

Sustainable Energy Development

under Uncertainty

UNU-MERIT Dissertation Series, № 50

\section{Geranda Notten}

Measuring and Managing Poverty

Risks

MGSoG Dissertation Series, № 1

2007

\section{Tobias Kronenberg}

Reconciling Environmental

Conservation with Economic

Prosperity: The Feasibility of Double

Dividends in the Short and Long Run

UNU-MERIT Dissertation Series, № 49

\section{Viktoria Kravtsova}

Assessing the Impact of Foreign Direct Investment in Transition Economies UNU-MERIT Dissertation Series, № 48

\section{Suhail Sultan}

The Competitive Advantage of Small and Medium Sized Enterprises: The Case of Jordan's Natural Stone Industry UNU-MERIT Dissertation Series, № 47

\section{6}

\section{Bulat Sanditov}

Essays on Social Learning and Imitation

UNU-MERIT Dissertation Series, № 46

\section{Mamata Parhi}

Dynamics of New Technology Diffusion: A Study of the Indian Automotive Industry UNU-MERIT Dissertation Series, № 45

\section{Andreas Reinstaller}

Social Structures and the Innovation Process: Their Role in the Demand of Firms and Consumers

UNU-MERIT Dissertation Series, № 44

\section{Rose Kiggundu}

Innovation systems and Development: The Journey of a Beleaguered Nile Perch Fishery in Uganda UNU-MERIT Dissertation Series, № 43 


\section{Thomas Pogue}

The Evolution of Research

Collaboration in South African Gold

Mining: 1886-1933

UNU-MERIT Dissertation Series, № 42

\section{Geoffrey Gachino}

Foreign Direct Investment, Spillovers and Innovation: The Case of Kenyan

Manufacturing Industry

UNU-MERIT Dissertation Series, № 41

ÖnderNomaler

Technological Change, International

Trade and Growth: An Evolutionary,

Multi-Agents-Based Modeling

Approach

UNU-MERIT Dissertation Series, № 40

2005

Samia Satti Osman Mohamed-

Nour

Change and Skill Development in the Arab Gulf Countries

UNU-MERIT Dissertation Series, № 39

\section{Elad Harison}

Intellectual Property Rights:

Economics and Policy Analysis

UNU-MERIT Dissertation Series, № 38

\section{Daniel Dalohoun}

The Relationship between RED

Partnership Formation, Social

Embeddedness and Innovative

Performance: a Multi-level Approach

of Social Embeddedness

UNU-MERIT Dissertation Series, № 37

\section{Müge Ozman}

Networks, Organizations and

Knowledge

UNU-MERIT Dissertation Series,

№ 36

\section{Bas Straathof}

Product Variety and Economic

Growth: The Counteracting Effects of

Scale and Idiosyncrasy

UNU-MERIT Dissertation Series, № 35

\section{Wilfred Schoenmakers}

Knowledge Flows between

Multinational Companies: A Patent

Data Analysis

UNU-MERIT Dissertation Series,

№ 34

\section{Myriam Cloodt}

Mergers and Acquisitions ( $M$ and As) in High-Tech Industries: Measuring the Post-M and A Innovative Performance of Companies UNU-MERIT Dissertation Series, № 33 


\section{Paola Criscuolo}

$R \mathcal{E D}$ Internationalisation and

Knowledge Transfer: Impact on MNEs and their Home Countries

UNU-MERIT Dissertation Series, № 32

\section{Maarten Verkerk}

Trust and Power on the Shop Floor UNU-MERIT Dissertation Series, № 31

\section{Gottfried Leibbrandt}

Adoption, Harmonization and Succession of Network Technologies across Countries

UNU-MERIT Dissertation Series, № 30

\section{Mark Sanders}

Skill Biased Technical change: Its Origins, the Interaction with the Labour Market and Policy Implications UNU-MERIT Dissertation Series, № 29

2003

Nadine Roijakkers

Inter-firm Cooperation in High-tech Industries: a Study of RED

Partnerships in Pharmaceutical

Biotechnology

UNU-MERIT Dissertation Series, № 28
Speed, Scale and Sustainability

UNU-MERIT Dissertation Series, № 27

\section{Masaru Yarime}

From End-of-Pipe Technology to Clean Technology

UNU-MERIT Dissertation Series, № 26

\section{StéphaneMalo}

The Combinatorial Chemistry

Revolution: Sustaining a Superior

Performance Position through

Technological Learning

UNU-MERIT Dissertation Series, № 25

2002

\section{Annelies Hogenbirk}

Determinants of Inward Foreign

Direct Investment: the Case of the

Netherlands

UNU-MERIT Dissertation Series, № 24

\section{Bastiaan Johan terWeel}

The Computerization of the Labour Market

UNU-MERIT Dissertation Series 


\section{Marjolein Caniëls}

\section{John Adeoti}

Technology Investment in Pollution Control in Sub-Saharan Africa: The Case of the Nigerian Manufacturing Industry

UNU-MERIT Dissertation Series, № 23

\section{Edward Huizenga}

Innovation Management: How

Frontrunners Stay Ahead: An

Empirical Study on Key Success

Factors in the ICT sector

UNU-MERIT Dissertation Series, № 22

2000

\section{Machiel van Dijk}

Technological Change and the

Dynamics of Industries: Theoretical Issues and Empirical evidence from Dutch Manufacturing UNU-MERIT Dissertation Series, № 21

\section{9}

\section{Jan Cobbenhagen}

Managing Innovation at the Company Level: A Study on Non-Sector-Specific Success Factors UNU-MERIT Dissertation Series, № 20
Regional Growth Differentials: The Impact of Locally Bounded Knowledge Spillovers

UNU-MERIT Dissertation Series, № 19

\section{8}

\author{
Aldo Geuna \\ Resource Allocation and Knowledge \\ production: Studies in the Economics \\ of University Research \\ UNU-MERIT Dissertation Series, \\ № 18 \\ 1996

\section{Reinoud Joosten} \\ Dynamics, Equilibria, and Values \\ UNU-MERIT Dissertation Series, \\ № 17
}

\section{Hugo Kruiniger}

Investment, $R \mathcal{E} D$, and the Financing Decisions of the Firm

UNU-MERIT Dissertation Series, № 16

\section{5}

\section{Hans van Meijl}

Endogenous Technological Change: The Case of Information Technology, Theoretical Considerations and Empirical Results UNU-MERIT Dissertation Series, № 15 


\section{René Kemp}

Environmental Policy and Technical

Change: A Comparison of the

Technological Impact of Policy

Instruments

UNU-MERIT Dissertation Series, № 14

\section{Rohini Acharya}

The Impact of New Technologies on

Economic Growth and Trade: A Case

Study of Biotechnology

UNU-MERIT Dissertation Series, № 13

\section{Geert Duysters}

The Evolution of Complex Industrial Systems: The Dynamics of Major IT Sectors

UNU-MERIT Dissertation Series, № 12

\section{MarjanGroen}

Technology, Work and Organisation: A Study of the Nursing Process in Intensive Care Units

UNU-MERIT Dissertation Series, № 11

1994

\section{Huub Meijers}

On the Diffusion of Technologies in a Vintage Framework: Theoretical Considerations and Empirical Results UNU-MERIT Dissertation Series, № 10

\section{Theon van Dijk}

The Limits of Patent Protection: Essays on the Economics of Intellectual

Property Rights

UNU-MERIT Dissertation Series, № 9

\section{Hans Voordijk}

Naar Integrale Logistiek in

Bedrijfsketens: Ontwikkelingen in de

Bouw

UNU-MERIT Dissertation Series, № 8

1993

\section{Paul Diederen}

Technological Progress in Enterprises and Diffusion of Innovation:

Theoretical Reflections and Empirical Evidence

UNU-MERIT Dissertation Series, № 7

\section{Ben Dankbaar}

Economic Crisis and Institutional Change: The Crisis of Fordism from the Perspective of the Automobile Industry UNU-MERIT Dissertation Series, № 6

\section{Hanno Roberts}

Accountability and Responsibility: The Influence of Organisation Design on Management Accounting UNU-MERIT Dissertation Series, № 5 


\section{Bart Verspagen}

Uneven Growth between

Interdependent Economies: An

Evolutionary View on Technology

Gaps, Trade and Growth

UNU-MERIT Dissertation Series,

№ 4

\section{Sjoerd Romme}

A Self-organization Perspective on Strategy Formation

UNU-MERIT Dissertation Series, № 3
John Spangenberg

Economies of Scale, and Atmosphere in

Research Organisations

UNU-MERIT Dissertation Series,

№ 2

1988

\section{John Hagedoorn}

Evolutionary and Heterodox

Innovation Analysis: A Study of

Industrial and Technological

Development in Process Control and

Information Technology

UNU-MERIT Dissertation Series,

№ 1 